CLAUDEMIR BELINTANE

\title{
A ORALIDADE FAZ ESCRITA NA(S) INFÂNCIA(S): PESQUISAS E REFLEXÕES SOBRE A RELAÇÃO ORALIDADE- ESCRITA NOS ANOS INICIAIS DE ESCOLARIZAÇÃO
}

Tese apresentada à Faculdade de Educação da Universidade de São Paulo - FE-USP para a obtenção do título de Livre Docente

FEUSP

São Paulo, 2011 
Catalogação na Publicação

Serviço de Documentação da Faculdade de Educação

Faculdade de educação da Universidade de São Paulo

\section{Belintani, Claudemir}

A oralidade faz escrita na(s) infância(s). Pesquisas e reflexões sobre a relação oralidade-escrita nos anos iniciais de escolarização

São Paulo, 2011

Tese de Livre Docência.

Área de concentração: Linguagem e Educação. Faculdade de Educação da Universidade de São Paulo.

1. Oralidade, 2. alfabetização, 3. leitura, 4. Escrita, 5. inconsciente, 6. subjetividade. 
FOLHA DE APROVAÇÃO

BELINTANE, CLAUDEMIR. A oralidade faz escrita na(s) infância(s): pesquisa e reflexões sobre a relação oralidade-escrita nos anos iniciais de escolarização.

Tese apresentada à Faculdade de Educação da USP para obtenção do título de Livre-docente.

APROVADO EM

\section{BANCA EXAMINADORA}

Prof. Dr.

Instituição Assinatura

Prof. Dr.

Instituição Assinatura

Prof. Dr.

Instituição Assinatura

Prof. Dr.

Instituição Assinatura

Prof. Dr.

Instituição Assinatura 
À minha esposa e companheira

Karyn Bulbarelli.

(o cruzamento de nossas existências

em nosso temperamento cotidiano prova que as diferenças

fazem as essências).

\begin{abstract}
A meus filhos,
Bruno e Júlio, por compartilhamos, nessas décadas high tec, certo jeito caipira de olhar, de escutar e de encasquetar com coisas perdidas.
\end{abstract}

Ao jeito sossegado e lúcido de minha mãe, Isaltina Videira Belintane, de aproximar sua vida e sua história da casa dos noventa. 


\section{AGRADECIMENTOS}

Em primeiro lugar, a meus interlocutores do grupo Oralidade-Escrita, os de agora e os de dantes;

à Maria Celeste Arantes Correia, a leitura e a revisão revigorante, que além de limpar o joio, aponta muito bem os ramos mais díspares do trigo.

a meus filhos Bruno e Júlio, a ajuda nos recorte-coles da bibliografia, das imagens e outros.

ao colega Júlio Groppa Aquino, as preciosas dicas e incentivos.

aos meus colegas, professores e funcionários da FEUSP, o incentivo e o apoio durante esta trajetória.

\section{AGRADECIMENTOS INSTITUCIONAIS}

à FAPESP - FUNDAÇÃO DE AMPARO À PESQUISA DO ESTADO DE SÃO PAULO, o financiamento do Projeto2006/61047-0 "Ensinando a leitura e a partir de diagnósticos orais"

à CAPES - COORDENAÇÃO DE APERFEIÇOAMENTO DE PESSOAL DE NÍVEL SUPERIOR/PROGRAMA OBSERVATÓRIO DA EDUCAÇÃO /INEP/SECAD pelo financiamento do Projeto: "O Desafio de Ensinar a leitura e a Escrita no contexto do ensino fundamental de nove anos e da inserção do lap top na escola pública brasileira" 


\section{RESUMO}

Partindo de uma concepção teórica construída entre a Linguística, a Análise do Discurso e a Psicanálise e, ainda, tendo como universo discursivo e de atuação o campo do ensino, esta tese apresenta uma proposta de abordagem da relação oralidade-escrita para o período de alfabetização, mais precisamente, busca uma articulação entre a Educação Infantil e o Ensino Fundamental. Usando a metáfora de uma dobradiça articulatória entre os dois períodos e, ao mesmo tempo, a metáfora da faixa de Moëbius para considerar a relação oralidade-escrita, a reflexão avança em três tópicos complementares. (1) No primeiro capítulo, procura-se articular um conceito de oralidade especialmente para o ensino, concebendo-a como uma modalidade distinta da fala cotidiana, mas com ela moëbianamente implicada, a partir da qual se põe em relevo o papel da função poética e da literatura na alfabetização, considerando, sobretudo, a possibilidade produtiva do conceito, que aqui se nomeia como "subjetividade de entre-texto", durante o período de entrada da criança na escrita. Para se apurar esse conceito de oralidade, que em si já implica uma dinâmica linguageira de escrita, estende a reflexão teórica, incorporando elementos importantes da história da escrita e da leitura. (2) No segundo capítulo, faz-se uma incursão no campo aplicado a partir de análises de vários documentos (avaliações do INEP, SARESP e PROVA DA CIDADE 2009; Guia do PNLD de 2010, 2011, 2012 e de três manuais didáticos) elabora-se uma crítica do modo como os intelectuais dos governos assimilam as teorias (concepção de língua, de letramento, de gêneros) e as transpõem para as redes públicas brasileiras. (3) No terceiro capítulo, apresentase uma reflexão a partir de várias experiências: uma pesquisa de dois anos de duração dentro de uma escola pública paulistana; uma convivência de três anos com uma comunidade de estudantes considerada em níveis não adequados de alfabetização - crianças e jovens provenientes de favelas da zona oeste de São Paulo; uma pesquisa em rede ainda em andamento. Procura-se mostrar 0 resultado dessas intervenções de ensino, cujos projetos foram elaborados a partir da concepção desenvolvida no capítulo I, que põe em relevo o papel dos gêneros de origem oral e da literatura durante o período de alfabetização. Por fim, a conclusão reforça a importância de se privilegiar a oralidade e a função poética em vez de assumir a concepção pragmática de cidadania vista no capítulo II.

PALAVRAS-CHAVE: Oralidade, alfabetização, escrita, leitura, inconsciente, subjetividade. 
From a theoretical framework built between Linguistics, Discourse Analysis and Psychoanalysis, and also focusing the field of education and its universe of discourse and action, this thesis presents a proposed approach to the relation between orality and writing during literacy teaching period; more precisely, it seeks a link between the kindergarten and elementary school. Using the metaphor of an articulation hinge between the two periods and, at the same time, the metaphor of the Moëbius band to consider the relationship between orality and writing, the reflexion advances in three complementary topics. (1)The first chapter seeks to articulate a concept of orality especially for education, conceiving orality as a distinct mode of everyday speech, yet both are implicated in a moëbiusian way; this conception highlights the role of the poetic function and of literature in literacy process, considering especially the possibility of the productive concept, which is named here as " inter-text subjectivity". In order to refine this concept of orality, which in itself implies a language dynamic of writing, this paper extends the theoretical reflection, incorporating important elements of the history of writing and reading. (2) The second chapter provides a foray into the applied field from analysis of various documents (INEP assessments, SARESP 2009 and Proof of the City; Guides PNLD 2010, 2011, 2012 and three textbooks), and elaborates a critique of how government staffs assimilate intellectual theories (conception of language, literacy, genres) and how they transpose them into the network of Brazilian public schools. (3) The third chapter presents a reflection from a variety of experiences: a survey of two years duration in a public school in Sao Paulo; the coexistence of three years with a community of learners in inadequate levels of literacy - children and young people from the slums of the city of São Paulo; a network research still in progress. It will be shown the result of these educational interventions, whose projects have been developed from the concept developed in Chapter I, which highlights the role of genres of oral origin and of literature during the literacy learning process. Finally, the conclusion reinforces the importance of privileging orality and poetic function rather than take a pragmatic conception of citizenship seen in Chapter II.

KEYWORDS: Orality, literacy, reading, writing, unconscious, subjectivity. 


\section{SUMÁRIO}

1. Introdução...................................................... 09

2. Capítulo I : Oral e escrito fazendo letras........................21

3. Capítulo II: Do literal ao literário...............................100

4. Capítulo III : Experiências e pesquisas..........................190

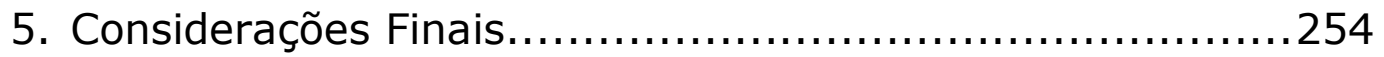

6. Referências bibliográficas..................................237 


\section{INTRODUÇÃO}

Em minhas pesquisas sobre leitura e alfabetização, nesses últimos dez anos, venho me deparando com um conjunto de questões extremamente difíceis de serem articuladas. Como lido cotidianamente com a formação inicial e contínua de professores, tais questões põem-me diante do impossível freudiano ${ }^{1}$, que para mim, desde meu doutorado, tomou a forma de uma divisa que define meu trabalho num campo epistemológico complexo, paradoxal, no qual os conceitos, as relações interdisciplinares, as estratégias e ações vacilam e recuam, sobretudo quando diante das certezas e plenitudes em voga.

Quando defendi minha tese de doutorado, um dos membros da banca, ao se deparar com minha tentativa de articular três campos de conhecimento, a Linguística (de Saussure e de Benveniste), a Psicanálise (de Freud e Lacan) e o Ensino de Língua Portuguesa no Brasil, não se conteve e fez uma brincadeira que até hoje não deixa de me estimular: Você preparou um canhão pra atirar num tico-tico?!

Mal sabia ele que eu poderia situar o tal tico-tico desde antes e em outro campo: em Macunaíma de Mário de Andrade, no capítulo XII, Tequeteque, Chupinzão e a Injustiça dos Homens, temos uma cena que dá o que pensar - vejamos o trecho todo, que vale a pena:

O ticotico era pequetitinho e o chupim era macota. $O$ ticotiquinho ia dum lado pra outro acompanhado sempre do chupinzão chorando pro outro dar de comer pra ele. Fazia raiva. O ticotiquinho imaginava que o chupinzão era filhote dele mas não era não. Então voava, arranjava um decumê por aí que botava no bico do chupinzão. Chupinzão engolia e pegava na manha outra vez: "Ihihih! mamãe... telo decumê!....telo

\footnotetext{
${ }^{1}$ Prefácio a Juventude Desorientada, de Aichhorn. Volume XIX (1925), a referência foi retomada em 1937 em Análise Terminável e Interminável - Volume XXIII. Nessas duas obras, Freud põe a educação ao lado dos atos de governar e psicanalisar, como uma das três profissões impossíveis.
} 
decumê!...". Lá na língua dele. O ticotiquinho ficava azaranzado porque estava padecendo fome e aquele nhenhenhém-nhenhenhén azucrinando ele, atrás, dizque "Telo decumê!"..."telo decumê!..." não podia com o amor sofrendo. Largava de si, voava buscar um bichinho uma quirerinha, todos esses decumês, botava no bico do chupinzão, chupinzão engolia e principiava atrás do ticotiquinho outra vez. Macunaíma estava meditando na injustiça dos homens e teve um amargor imenso da injustiça do chupinzão. Era porque Macunaíma sabia que de primeiro os passarinho foram gente feito nós....Então o herói pegou um porrete e matou o ticotiquinho. (1977 p. 146)

Atravessando esse texto com um trecho da Instância da Letra no Inconsciente (1998), em que Lacan se ocupa brilhantemente de um verso do poema de Victor Hugo, Booz endormi², para dar uma ideia de seu conceito de metáfora, realçando sobretudo o efeito de retroação significante que vai encontrar um "falo" num "feixe de trigo", posso também extrair aqui do trecho de Mário que o ticotiquinho é coisa de gente feito nós, tanto esse que caiu no porrete de Macunaíma como o que me puseram na frente de meu canhão. 0 narrador de Mário não diz, mas não deve ter sido fácil acertar na primeira cacetada um ticotiquinho com seus saracoticos por mais esfalfado que ele estivesse, de tanto buscar os decumê para o chupinzão.

Para além das alegorias, o meu problema nesta tese é lidar com esse canhestro canhão e com as coisas ticotiquizantes e chupinhantes que me aparecem pela frente em nossas pesquisas nas escolas públicas, nas orientações e nos destrilhamentos e derivas que as leituras literárias e as de Freud e Lacan me provocam. De fato, trago para meus orientandos uma herança teórica pesada, difícil, complexa demais, que leva tempo e muita paciência para que ela possa minimamente bordejar os impossíveis da educação. Se as influências

\footnotetext{
${ }^{2}$ Sa gerbe n'était point avare ni haineuse ; assim traduzido: Seu feixe não era avaro nem odioso (p. 510)
} 
teóricas que pretendo criticar aqui chegam enviesadas na escola, como chegariam as minhas cuja complexidade teórica extrapola ainda mais a aparência plácida da realidade? Devo levar o canhão para a escola ou rever minha formação como tico-tico diante de uma escola chupinhante?

Quando se comparam minhas pesquisas e as de meus orientandos com outras do campo do ensino da leitura e da escrita, sejam as construtivistas, sociointeracionistas ou mesmo as oriundas do cognitivismo neurobiológico dos defensores do método fônico para alfabetização de crianças, é inevitável certo manquejar pro nosso lado, já que, em quase todas as universidades, assistimos a um domínio quase completo, sobretudo das duas primeiras. E, como já mostramos em Belintane (2006), a terceira também vem se destacando nos meios de comunicação. Talvez haja entre essas perspectivas - guardadas todas as diferenças entre elas - um fio discursivo que, infeliz e facilmente, transforma-se em uma promessa de mobilização de subjetividades propulsoras de ações pedagógicas certeiras. Passemos rapidamente por elas para clarear um pouco mais essa nossa afirmação.

Nas construtivistas, o pesquisador pode facilmente pôr para trabalhar sujeitos concretos, de diversas faixas etárias, debruçados sobre objetos ou mesmo suportes de escritas e, dessas ações, colher dados diretamente, quantificá-los, ordená-los, como fizeram, e muito bem, Ferreiro \& Teberosky (1989), com um objetivo bem claro: ...presentear la interpretación del proceso, desde el punto de vista del sujeto que aprende, basada en los datos obtenidos durante dos años de trabajo experimental com niños de entre 4 y 6 años (p. 13). A partir daí, como alguns o fizeram no Brasil, alguém pode ir diretamente ao campo aplicado, mesmo à revelia do que pensam os autores da pesquisa original e emplacar no mínimo três ideias norteadoras de ações pedagógicas:

- o sujeito constrói o conhecimento; 
- o processo se dá por meio de fases que podem ser definidas e utilizadas como diagnóstico de conhecimento da escrita;

- mesmo com todas as imperfeições e relativizações apontadas por Ferreiro, a escrita é um objeto bem concreto e pode ser compreendida como representação da fala.

Da vertente sociointerativa, depreende-se que a relação entre sujeito e linguagem é constitutiva; no entanto, as concepções de Vigotski assumem um conceito de linguagem que põe o significado ou o sentido como centro de uma consciência produtiva. Apesar de introduzir a dimensão social por meio da linguagem e apontar para um sujeito ativo que se constitui a partir do outro, sua concepção da fala ou mesmo da língua se prende à função comunicativa. A palavra apesar de ser para o pesquisador soviético o microcosmo da consciência humana (1987, p.132), sua característica fundamental é uma reflexão generalizada da realidade (pp. 131,132). Mesmo se acrescentarmos as concepções enunciativas de Bakhtin (Volochinov) (1979), Bakhtin(1992), a subjetividade continuaria sendo demarcada por um ponto de partida (discurso do outro) e outro de chegada (consciência própria). Não há dúvida que o pensamento do círculo bakhtiniano trouxe inovações espantosas para os estudos da linguagem, mas em minhas buscas faz falta a torrente intrínseca da singularidade, que Lacan nomeou Real e que Milner (1987) estende para a língua (real da Língua). A visão de Bakhtin fixa um exterior e um interior, enquanto a de Lacan pontua uma subjetividade entre um Outro e um outro (como veremos no capítulo I) em um percurso que permite integrar moëbianamente a interioridade e a exterioridade, a infância e o mundo adulto.

Entre o fluxo discursivo que essas vertentes das últimas décadas produziram em educação e que edulcora o discurso dos formadores universitários da educação e os projetos do governo pode -se ver, nos dias atuais, um trânsito mais consensual, sobretudo quando se trata de convencer uma banca, um parecerista, ou de 
justificar um projeto para os órgãos públicos, em outras palavras, essas vertentes constituem paradigmas bem estabelecidos e dão as cartas nos governos.

Já o discurso que envolve meu grupo de pesquisa ainda anda esgarçado! Na hora de elaborar um projeto para os órgãos de fomento à pesquisa, por exemplo, não é nada fácil mostrar quais os potenciais dessa imensa armação teórica no campo aplicado. Ao longo desses últimos anos é que conseguimos ir afinando alguns conceitos difíceis de manejar, que serão vistos ao longo desta obra, mas, ainda, na hora das parcerias e diálogos, nem sempre é fácil mostrar as potencialidades de seus impossíveis.

A política educacional (o governar), seguindo suas metas internacionais, também é uma das inevitáveis fontes que multiplicam as dificuldades. Cumprir a meta internacional, "pôr toda criança na escola", não deixa de ser uma premência inevitável, uma meta diante da qual nenhum governo hesitaria; contudo, a implementação apressada, a falta de infraestrutura material e humana e ainda as complexidades oriundas das mudanças sociais e tecnológicas das últimas décadas vêm invertendo essa democratização. Pôr toda criança na escola, que também significa garantir o fluxo sem acumular altos percentuais de retenção, sobretudo nos ciclos iniciais, tornou-se um "possível" político que agiganta os "impossíveis" do ensino - a ponto de levar a escola pública à paradoxal categoria de "possível, mas impotente", que é de outra ordem se compararmos com o impossível freudiano, que contém em si a potência, o desafio, pois mesmo lançando o sujeito nas bordas do "umbigo do sonho", não cessa de produzir incertezas úteis, quase ficcionais, mas produtivas, que podem engendrar discursos potentes, capazes de subsidiar uma práxis mais dialética.

O Real, que corrói certezas, tento levar em conta como uma dimensão que revelará sempre as fraquezas de nosso logos. Daí o cuidado com as dicotomias e a busca incessante por um terceiro eixo. 
Se por um lado tento cerzir um tecido teórico complexo no afã de encontrar novas possibilidades de abordagem do campo do ensino da leitura e da escrita, de outro procuro refletir sobre as (im) possibilidades (im)potentes dessas reflexões na sala de aula da escola brasileira.

Outro ingrediente que se soma ao quadro dos impossíveis vem escrito nos programas de governo, desde os Parâmetros Curriculares Nacionais até as avaliações e os planos de livro didático (PNLD) para as escolas públicas. Se levarmos em conta o ensino da leitura e da escrita nesses nossos tempos em que o suporte eletrônico, as redes de computadores e outros meios competem duramente com a escolarização e, ainda, se considerarmos que o alto percentual de crianças que não dominam o alfabeto mesmo após quatro anos de escolarização (como mostram as avaliações dos governos que iremos analisar no capítulo II) vive em comunidades que privilegiam certa oralidade em detrimento da escrita, temos motivos de sobra para tentar, apesar de toda a complexidade, cotejar essas frentes e daí extrair alguma síntese proveitosa para o ensino. Antes de mostrar nossas concepções, resolvemos contrapô-las às que nutrem os programas de governo. Nosso capítulo II se divide, portanto, em duas partes: na primeira, analisamos três modelos de avaliação e suas influências teóricas: o documento que apresenta o modelo da Prova Brasil (do INEP); duas avaliações, uma do SARESP (Ensino Fundamental I) e outra, a Prova da Cidade (Final de ciclo do Fundamental I, da rede municipal de São Paulo), e acrescentamos os documentos que apresentam os Guias dos Livros Didáticos (outro programa de governo) e ainda mais três manuais didáticos que o PNLD-2010 remeteu para as três escolas públicas que estão sendo por nós pesquisadas (Belém- PA, Pau dos Ferros-RN, São Paulo $\mathrm{SP})$.

Alfabetizar, ensinar a leitura, por mais que se disfarce em "filosofias" e "concepções", sempre se deu por meio de métodos e 
metodologias que, de alguma maneira, dispensam a complexidade e apostam em esquemas facilitadores, que parecem corroborar a ideia de que educar não só é um bem possível, mas também facilmente formulável. Os defensores do método fônico, por exemplo, chegam mesmo a garantir que podem zerar os percentuais indesejáveis dos sistemas públicos de ensino (essa metodologia certeira foi abordada em Belintane, 2006). Na rede estadual (SP) e no município de São Paulo, praticamente foi adotado o "construtivismo de Emília Ferreiro" - os professores bimestralmente classificam e reclassificam seus alunos utilizando os níveis propostos por Ferreira y Teberosky (1989). O resultado é que até criança de seis anos já se sabe e se conforta como "pré-silabis".

A perspectiva aqui desenvolvida, em primeiro plano procura reconhecer e assumir, como campo privilegiado de leitura, o espaço interdisciplinar que se vem abrindo entre a Linguística e a Psicanálise - perspectiva essa que nasce da releitura que Lacan fez da obra de Freud, tendo como referência a linguística de Saussure e Jakobson e o estruturalismo de Lévi-Strauss. A partir dessa releitura, sobretudo do foco posto no aforismo lacaniano, o inconsciente estrutura-se como linguagem, acompanharemos - nem sempre com eles concordando - alguns autores que aprofundam algumas metáforas ou mesmo alegorias usadas por Freud e enfatizadas por Lacan, que implicam o campo da escrita, sua história e sua funcionalidade simbólica. Dentre os lacanianos que levaram adiante alguma proposta baseada na História da Escrita, destaca-se a de Pommier, que em seu "Naissance et renaissance de l' écriture", mostra a possibilidade de novas reflexões sobre o cruzamento entre a gênese e a ontogênese da escrita gráfica e de sua relação com fenômenos psíquicos ligados ao processo de recalcamento, à castração, ao complexo de Édipo. Partindo de "Moisés e o Monoteísmo" de Freud e das perspectivas abertas pela releitura de Freud por Lacan, Pommier retoma a escrita 
e a letra a partir de ambiguidades que permitem pensar as manifestações do inconsciente:

La découverte historique de l'écriture et son apprentissage individuel suivent peut-être le même chemin. Mais por soutenir cette hypothèse d'une correspondance entre phylogenèse et ontogênese, il foudrait montrer que lês étapes de certaines inventions, élaborées em quelques milénaires, doivent être à nouveau franchies en quelques années par chaque enfant. (p. 7)

O autor busca um acontecimento diacrônico comum entre as passagens da escrita pictográfica para o alfabeto e do desenho infantil para a escrita: a emergência do monoteísmo na história da escrita e o complexo de Édipo na vida da criança. Para isso, parte da seguinte hipótese, que Freud(1988) ${ }^{3}$ esboça ligeiramente no Moisés e o Monoteísmo: Surge mesmo uma suspeita de que os israelitas daquele período primitivo - o que equivale a dizer, os escribas de Moisés - podem ter tido alguma parte na invenção do alfabeto (p.55). Em nota de rodapé a esta página, Freud acrescenta que se os escribas estiveram sujeitos à proibição posta por Akhenaton (Amenófis IV) quanto ao uso dos hieróglifos originários do politeísmo praticado até então pela tradição egípcia, que se baseava numa infinidade de imagens religiosas, eles ficaram limitados a poucos símbolos e isso resultaria em um uso mais simbólico e menos iconográfico das poucas imagens permitidas. Se os escribas não podiam lançar mão das imagens, sua escrita poderia se reduzir, pela via do rebus, aos caracteres fonéticos que já existiam na escrita hieroglífica. Essa passagem, apesar de não ser amplamente desenvolvida nessa obra de Freud, menciona dois procedimentos muito persistentes no judaísmo e bem desenvolvidos no livro: o culto ao Deus único e a proibição de fornecer uma imagem de Deus. Pommier vai persistir nessas indagações e fazer dela o eixo de suas reflexões sobre ontogênese e filogênese:

\footnotetext{
${ }^{3}$ Volume XXIII (1939)
} 
Il foudrait dégager ce qu'il peut y avoir de commun aussi bien au rêve, au dessin, au pictogramme qu'a la lettre d'alphabet. L'instance de la lettre dans l'inconscient, telle que la psychanalyse la définit, ne permet-elle pas de situer cette formalisation première de l'écriture, commune a tous, bien que chacun doive la réinventer? Quelle que soit la façon dont il comunique son message, on pourra montrer que le graphisme de I'homme descend du songe. Seront em ce sens littérales l'image du rêve, le dessin, le calligramme, ou la lettre d'alphabet. (p. 12)

Suas indagações partem da comparação entre os primeiros desenhos da criança e as imagens dos sonhos - por aquelas constrições não se submeteriam eles também a uma repressão, cujo resto seria a escrita? Do gozo do grafismo - soltura no caos -, do desenho, pregnância da imagem, à disciplina do alfabeto, não haveria aí uma contenção de uma corporalidade gozosa? Essas questões renderam muito na obra do psicanalista francês, que irá sustentar que os primeiros desenhos representam fantasmas, que serão tomados pelo recalque até o ponto em que o retorno do recalcado se localiza na letra. Entre o espaço do desenho e o espaço da letra, o autor localiza o espaço do recalque e da repressão. No entanto, como veremos no capítulo I, para nós a questão mais importante será exatamente a que Pommier despreza, ou seja, a corporalidade do rapsodo, que o surgimento da escrita esvanece em contraste com a nova corporalidade "soft" que a escrita inaugurará ao longo de seu domínio, ou seja, um corpo fantasiado capaz de se desprender da voz e vagar por cima das letras.

Neste campo temático que reúne psiquismo e escrita, procuramos incrementar as incursões à psicanálise lançando mão de autores dos campos da história da escrita e da leitura. Para nós, educadores que lidamos com o ensino da escrita, essa conjunção é bastante fértil e produtiva, sobretudo se a cotejarmos com conhecimentos de pesquisadores como Adam Parry e Alfred Lord, Éric 
Havelock, Walter Ong, David Olson, Roger Chartier, Guglielmo Cavallo, Paul Saenger e de outros que dão relevo ao milenar embate entre cultura oral e cultura escrita. As abordagens dos lacanianos são interessantes, mas se limitam aos fenômenos mais estruturais da história da escrita ou à dinâmica da própria clínica. Por outro lado, esses estudos historiográficos, sociológicos e linguísticos não levam em conta as concepções mais refinadas da Psicanálise, por exemplo, os conceitos de sujeito, significante, a tríade real-simbólicoimaginário de Lacan. Daí a razão de ocuparmos esse intervalo.

No Brasil, nossas leituras encontraram diversos autores que investem nessa conjunção entre psicanálise e linguística, ou mesmo psicanálise e análise do discurso. No plano da aquisição da linguagem, encontramos a obra de Cláudia de Lemos e de alguns de seus orientandos, que abrem perspectivas para o campo aplicado do ensino da escrita. Outra autoria duplamente interessante é a via aberta por Leda Tfouni, que além de privilegiar uma concepção heterogênea de letramento, em que a oralidade tem o seu peso, propõe uma abordagem desse conceito a partir de uma posição também intervalar, entre psicanálise e a análise do discurso francesa.

Após constatar que a transposição das importantes teorias que se divulgaram no Brasil nas décadas de oitenta e noventa foi tomada ao pé da letra e está provocando efeitos até mesmo contrários ao que preconizavam seus divulgadores, apresento na parte II uma proposta alternativa para enfrentar a heterogeneidade nas classes de alfabetização da escola brasileira.

No terceiro capítulo apresento dados, relatos de processos e reflexões extraídos de uma pesquisa concluída em 2009, e de uma experiência com alunos oriundos das favelas que se localizam nos entornos do CEAGESP (Zona Oeste de São Paulo). Essas descobertas não só complementam a parte II do segundo capítulo, como também mostram um campo aplicado complexo, mas com algumas possibilidades e potencialidades para essa nossa conjunção teórica. 
Por fim, a conclusão vem reafirmar os desvãos que tornam o impossível potente e reiterar que, em se tratando de alfabetização, a nossa concepção moëbiana de oralidade-escrita pode abrir um caminho novo, complexo, mas envolvente, sobretudo para educadores e formadores que sentem na pele o impossível real da escola brasileira.

Em resumo, os dois objetivos deste trabalho são: primeiramente, dar coesão às nossas conjunções teóricas para, com elas, reler o que se faz hoje no campo da alfabetização e da leitura na escola pública brasileira; posteriormente, mostrar o que delas já se apurou no campo aplicado, apresentando reflexões oriundas de nossas pesquisas e atuações, que, talvez, atestem o impossívelpotente de nossa proposta.

Por formular uma proposta clara, erigida num intervalo já esboçado no estado da arte geral das ciências humanas (linguística, psicanálise, análise do discurso), mas relativamente novo no campo da educação, considero o presente texto uma tese. O já escrito e os projetos anteriores foram reaproveitados (um deles, no caso o projeto Keizo, apresentado no capítulo III, traz dados e até mesmo reflexões retiradas diretamente de um artigo já publicado, mas aqui se somaram a dados e experiências ainda não aproveitados). De qualquer modo, o arranjo de todas essas lidas num fluxo de reflexão como o que aqui se constitui é absolutamente novo. Podemos garantir que o texto, em sua articulação, constitui uma tese nova. Seu ineditismo consiste em sustentar que a oralidade tal qual a concebemos, em sua dimensão performática, deve ser a base do processo de alfabetização, por conter, em sua dinâmica linguageira, elementos estéticos que favorecem uma posição subjetiva propícia ao ato de ler e de se defrontar com as demandas da escrita.

Antes de entrar no capítulo I, convém antecipar opções formais que assumimos: o fluxo do relato, das apresentações e do dissertar será feito na primeira pessoa do plural, mas de vez em quando um 
"eu" tomará as rédeas e isso deverá acontecer nas situações mais pontuais e específicas, as que implicam algum dado ou elemento mais pessoal e contextualizado. O uso de itálico será utilizado sempre para as referências bem localizadas, já as aspas entrarão quando se tratar de conjectura ou de retomada da palavra do outro de uma forma inespecífica ${ }^{4}$.

${ }^{4} \mathrm{Em}$ relação ao tipo de letra, optei pela Verdana, cujos contornos, além de elegante, são mais claros e legíveis do que a usual e muito fechada, Times New Roman. 


\title{
Capítulo I
}

\section{ORAL E ESCRITO FAZENDO LETRAS}

O poeta Manuel Bandeira escreve, em Itinerário de Pasárgada, que sua vocação para a poesia encontra origem em sua mais remota infância. A memória do poeta busca lá nos três anos de idade o manancial de sentimentos que ele identifica como de "natureza artística". Seu primeiro contato com a poesia, com os versos, teria ocorrido, segundo suas próprias palavras, a partir da escuta de contos de fadas e histórias da carochinha e ele faz questão de enfatizar a emoção que sentiu quando aos seis anos ouviu pela primeira vez a cantiga da menina enterrada viva, que aparece no conto A Madrasta; ouçamo-la:

\author{
Jardineiro de meu pai. \\ Não me cortes meus cabelos. \\ Minha mãe me penteava \\ Minha madrasta me enterrou \\ Pelo figo da figueira \\ Que o passarinho bicou. \\ Xô, passarinho!
}

Ainda hoje qualquer criança se extasia diante desse "xô passarinho", que marcou a infância de nosso poeta. Mais adiante, Bandeira reforça ainda que, mesmo após sua entrada na escola, dos seis aos dez, seus ouvidos captavam os gêneros populares, os pregões de rua e os textos que vinham das seletas escolares e mesmo dos jornais. De fato, em seus poemas - como o belíssimo Evocação do Recife - os gritos das crianças brincando, as vozes dos adultos nos festejos juninos e a dos pregões de rua dão ao poema um tom nostálgico, de uma felicidade que, apesar de perdida, deixa seus restos ali na memória franqueando a possibilidade poética. 
Jorge de Lima, importante poeta moderno, também nascido no final do século XIX, do mesmo modo que Bandeira, mostra-nos que a poesia esteve na base de sua escrita, vejamos o poema que escreveu quando tinha apenas sete anos:

\author{
Eu queria saber versos \\ como o meu amigo Lau. \\ Nunca vi versos mais belos \\ como ele sabe lá. \\ Trocava até meu carneiro \\ meu velocípede sim \\ sem saber os seus versos \\ meu Pai que será de mim? \\ Meu pai me bote na escola \\ de meu velho amigo Lau. \\ Quero aprender com ele \\ versos não $b, a$, bá. \\ (Lima, 1978. p. 9)
}

Bem provável que os dois poetas contaram com um berço urdido em versos e acolchoado de cantigas e histórias de toda sorte; em outras palavras, foram embalados em um ambiente parental e regional bastante rico em poesias, tanto as de origem oral como as da escrita.

Entretanto as coisas nem sempre são assim tão parentais. Há escritores, como, por exemplo, Graciliano Ramos, que parecem não ter experimentado um contato com esse aliciante estofo materno e paterno. Em seu livro Infância (Ramos, 1972), constatamos, já nos parágrafos iniciais, que os primeiros versos que o escritor ouviu, quando menino, não vieram da boca da mãe ou mesmo do pai. José Bahia, homem rude, espécie de jagunço que trabalhava na fazenda de seu pai, é que abria para ele as possibilidades do verso:

Eu nasci de sete meses

fui criado sem mamar

bebi leite de cem vacas

na porteira do curral. 
Retornos aos primeiros anos da vida, desses e de tantos outros escritores, mostram que os textos orais da infância estão por detrás de toda armação de linguagem que o adulto recria posteriormente, seja escrita, falada, pictórica ou mesmo corporal. Por exemplo, a cena de um jagunço cantando para uma criança de berço, Graciliano a recupera em São Bernardo, com o personagem Casimiro Lopes, jagunço ambíguo que, apesar de ser um assassino do tipo paumandado, mostra desvelo e carinho ao cuidar do filho do patrão, Paulo Honório:

E o filho chorava, chorava continuadamente. Casimiro Lopes era a única pessoa que lhe tinha amizade. Levava-o para o alpendre e lá se punha a papaguear com ele, dizendo histórias de onças, cantando para o embalar as cantigas do sertão. O menino trepava-lhe às pernas, puxava-Ihe a barba, e ele cantava:

Eu nasci de sete meses,

Fui criado sem mamar.

Bebi leite de cem vacas

Na porteira do curral.

(1996, p. 138)

Nos exemplos citados podemos notar o envolvimento dos três futuros escritores com textos bem diferentes daqueles que se poderiam transcrever a partir de uma fala coloquial (diálogo) entre pais e crianças. O que queremos dizer é que nem só de diálogo e de prosa cotidiana vive a criança pequena, pois desde o berço, sua linguagem em constituição é atravessada por uma verdadeira polifonia textual, entretecida a partir de suas relações com os pais, com outras crianças e outros adultos.

$\mathrm{Na}$ tentativa de compreender esses entrecruzamentos textuais, vamos fixar aqui dois eixos linguageiros que se interpenetram de forma bem dinâmica, constituindo, entre eles, essa tessitura discursiva, que desde cedo já revela os elementos e as funções mais 
essenciais da linguagem, inclusive as que podem fornecer as bases necessárias à entrada do sujeito na escrita. A partir dessa configuração, pretendemos discutir possibilidades interessantes de ensino da leitura e da escrita tomando como base, sobretudo do processo de alfabetização, o que definiremos aqui como oralidade infantil.

Para ilustrar esses dois eixos, poderíamos tão somente contrapô-los em duas faixas, constituindo o que seria uma dicotomia simples. Vejamos:

\begin{tabular}{l|l}
\multicolumn{1}{c|}{ Eixo A } & \multicolumn{1}{c}{ Eixo B } \\
manhês, & cantigas, \\
diálogo, & brincos, \\
relato de & parlendas, \\
acontecimento, & mnemonias, \\
conselho, & fórmulas de escolha \\
pedido, & conto (de fadas, \\
chamado, & de encantamento, \\
ordem, & acumulativo etc.) \\
fórmula de & adivinhas, \\
polidez etc. & provérbios, \\
& trava-línguas \\
etc.
\end{tabular}

Entretanto, quando levantamos os complexos fenômenos que ocorrem no uso da língua, percebemos que qualquer modelo imagético teria que admitir seu fracasso ${ }^{6}$. Se levarmos em conta as

\footnotetext{
5 Manhês é o termo que os pesquisadores da área de aquisição de linguagem atribuem à linguagem que as mães atualizam para falar com seus bebês. Consiste, em geral, em uma entonação exagerada, com picos prosódicos e com abrandamentos de consoantes oclusivas e de alguns encontros consonantais.

6 Dufour (2000) discute três possibilidades conceituais para ciência moderna e pósmoderna: a versão unária, a dicotômica (binária) e a ternária (trindade), insistindo que há uma tendência de o binário prevalecer. O filósofo francês leva em conta desde as oposições do estruturalismo aos atuais paradigmas que se beneficiam da lógica booleana da informatização, passando pela trindade lacaniana (Real, Imaginário e Simbólico). Nossa tendência, ao longo deste texto, é de considerar cada polo em sua força opositiva (por exemplo, os embates entre cultura oral e
} 
duas faixas, teríamos que explicar os atravessamentos, ou seja, os falantes, tanto adultos como crianças, fazerem as formas passar de uma para a outra sem pensar muito, na maioria das vezes por um efeito associativo; por exemplo: alguém, para dar um conselho, poderia o fazer contando uma história, uma fábula. Do mesmo modo, no interior de um causo, o contador faz esforços para imitar a fala cotidiana das pessoas; num telejornal, o âncora, embora esteja ancorando a sua leitura em um texto escrito, tenta expressar-se de forma espontânea, mais próximo possível da fala cotidiana.

Frequentemente, as crianças iniciam uma cantiga a partir de uma palavra que a enlaça. Graciliano Ramos mostra isso em Infância, quando, para se proteger de uma ameaça vinda do mundo adulto, a idéia de que o sapo boi morde como cachorro e, se pega um cristão, só o larga quando o sino toca (p.74) entra em uma associação que vai evocar um outro sapo, o da cantiga de ninar:

\author{
Sapo cururu \\ Da beira do rio. \\ Não me bote na água, \\ Maninha, \\ Cururu tem frio.
}

Cantiga para embalar crianças. Os cururus do açude choravam com frio, de muitos modos, gritando, soluçando, exigentes ou resignados. Eu também tinha frio e gostava de ouvir os sapos ( $p p$. 74-75)

Temos aí um belo exemplo da interpenetração e do enredamento dos dois eixos na memória infantil, embora aqui recriado literariamente. Outro caso que podemos citar como exemplo é o de Júlio7 (três anos) que, ao ouvir alguém dizer que um "gato"

cultura escrita), mas manter sempre a possibilidade de uma imbricação ou de uma terceira interferência (como o Real lacaniano incidindo sobre o laço do simbólico com o imaginário, ou seja, impedindo, com seu nonsense, que haja uma acoplagem perfeita entre simbólico e imaginário. (Lacan, R.S. I, 1974-1975)

${ }^{7}$ Sabemos que esse tipo de recolha de dados (pela convivência, pelo ouvido) não é muito recomendável pelas metodologias científicas, mas para nós ela é imprescindível e inevitável, pois se trata de flagrar algo que não comparece em entrevistas ou coletas estruturadas - nesse sentido, tem a mesma natureza de um 
havia entrado no quintal, dispara imediatamente a parlenda "cadê o toucinho daqui? O gato comeu! Cadê o gato...". Ou então o surpreendente e quase inexplicável pedido de Luíza (dois anos) à sua mãe em resposta a uma bronca que levou enquanto batucava em uma tigela com uma colher de pau:

"- Filha, você vai quebrar a tigela!

- Mãe, canta o pato!"

Aqui um fragmento da fala da mãe puxou imediatamente a música e a letra de $O$ pato de Vinicius de Morais, mais precisamente o verso quebrou a tigela, que imediatamente remete a criança ao texto da canção e ao seu título. Na repreensão da mãe, a mensagem punha a criança na posição de sujeito do verbo "quebrar"; com a associação, o pato vem ocupar esse lugar, dando à criança a vantagem - ainda que inconsciente - de sair da posição de quem merece uma bronca e, ainda, contando com a vantagem de migrar para uma situação mais privilegiada, a de quem escuta uma cantiga cantada pela mãe.

Essa relação intertextual ${ }^{8}$ tão importante entre uma palavra ou expressão da fala cotidiana e um texto completo anteriormente memorizado é bastante comum na vida das crianças que têm o privilégio de conviver com uma pluralidade de textos - aliás, é uma operação que abre o traçado de uma subjetividade de entre-textos ${ }^{9}$,

chiste. O que preserva alguma fidedignidade para o leitor é a verossimilhança, ou seja, dá pra perceber que a ocorrência é verossímil, que está próxima de situações que ocorrem em nossa vida cotidiana.

8 Esse conceito será utilizado na acepção mais consensual da análise do discurso, como explicitam Charaudeau \& Maingueneau (2004): O uso tem a tendência de empregar intertexto quando se trata de relações com fontes precisas (citação, paródia) e interdiscurso para conjuntos mais difusos: assim, dir-se-á frequentemente a fala se exerce em um vasto interdiscurso (p. 289). Em nosso caso, as relações se dão da fala prosaica para fontes precisas da tradição oral infantil.

9 Esse conceito, além de evocar o conceito de intertexto/interdiscurso da Análise do Discurso, remete também a Lacan (1998), que põe a subjetividade entresignificantes, como um efeito da cadeia significante. Como no ensino lidamos com textos orais e escritos, com imagens e filmes, é interessante continuar mantendo a ideia de excentricidade do sujeito (veremos mais adiante esse conceito), sua 
ou seja, um sujeito efeito das possibilidades de relações que os dois eixos proporcionam. Esse fenômeno, que no ensino de literatura é conhecido como intertextualidade, é um dos dispositivos fundamentais do bom leitor. Essa associação - é preciso frisar bem é imprevisível, nem o próprio falante percebe como ela se dá. A língua na infância, em seu enredamento discursivo com os textos da cultura, permite à criança exercer suas experiências estéticas e literárias, como, por exemplo, este encaixe métrico realizado por uma criança de cinco anos, que diante de sua tia se propôs a fazer uma música em homenagem "a você e ao Claudemir" e começou a cantar naturalmente:

\footnotetext{
"Alecrim, alecrim dourado

Que nasceu no campo

Sem ser semeado..."
}

Repetiu mais uma vez sem mudar uma palavra sequer. De repente, no verso seguinte, engata, no ritmo e na métrica, o nome do tio:

\section{"Foi o Clau de miiiir \\ que me disse assim \\ Que a flor do campo \\ é o alecriiiim!"}

Aqui notamos a associação entre a música que a tia cantava pra ele cotidianamente e o nome de seu tio. O encaixe métrico aí é surpreendente, o verso "foi o Claudemir", cantado no ritmo e na melodia da música, corresponde ao segmento métrico original, "foi meu amor!" e ainda reformula o sentido geral da cantiga, assimilando a ela sua proposta inicial de fazer uma homenagem à tia, introduzindo o nome do tio na pauta. É impressionante como seu desejo, sua intenção oculta (homenagear a tia, aceitando o tio, mas

natureza intervalar, mas ao mesmo tempo guindar o conceito para as unidades que nos interessam, então, poderemos ter subjetividades de entre-texto, de entrediscurso ou de entre-meios (é o caso de um posicionamento subjetivo ou de um impedimento, por exemplo, na passagem do oral (meio fônico) para o escrito (meio gráfico) ou para o eletrônico. Mantive o hífen para sinalizar o intervalo. 
sem perder o fio erótico que conduzia suas incômodas perguntas sobre o relacionamento dos casais) foi inconscientemente posta em palavras utilizando uma matriz textual que the veio da própria tia (a cantiga). Outro caso que recolhemos e que também impressiona é o de Rafaela (1,9 anos), no seguinte diálogo com a mãe:

\footnotetext{
"Mãe: - como se chama o seu ursinho?

Rafaela: se chama solidom"
}

Uma pessoa que não perceba os efeitos metafóricos e metonímicos da língua poderia cismar que a criança estivesse aí denunciando sua solidão, contudo temos aí um efeito associativo com a cantiga "Se essa rua fosse minha", mais precisamente com o verso "Nesta rua, nesta rua tem um bosque/que se chama, que se chama solidão"

A criatividade linguística de Graciliano, de Júlio, de Luíza, de Gustavo e Rafaela tem dinâmica próxima à de um chiste, em que uma pessoa engata à conversa uma associação sem tê-la planejado, como no exemplo abaixo entre dois vizinhos da cidade de São Paulo:

"- Como é que se explica essa falta de água repentina!

- É, acho que ninguém "SABESPLICÁ" essa calamidade! (ambos riem ao encontrar a sigla da empresa responsável pelo tratamento de água: SABESP inscrita em sabe explicá)"

Outro caso interessante que nos ajuda a questionar o conceito de consciência fonológica: Tomás (seis anos e meio), que por ser filho de um amigo, entretinha comigo uma relação muito próxima a ponto de me chamar de tio fulano (apelido familiar), teve que enfrentar uma situação de distanciamento quando se encontrou comigo no papel de coordenador escolar. Seu pai explicou-lhe que neste ambiente, na escola, ele não poderia utilizar esse apelido familiar e sim o nome Claudemir, que para o menino soava muito 
estranho. Ao se deparar comigo e ao me cumprimentar, cometeu esse interessante equívoco: " - Bom dia, prof. Valdemar!"

É interessante notar que a troca de Claudemir por Valdemar é uma homofonia das mais interessantes; vejamos o pareamento das sílabas e fonemas:

\begin{tabular}{|l|l|l|}
\hline$[$ klau $]$ & {$[$ de $]$} & {$[$ mir $]$} \\
\hline$[$ vau $]$ & {$[$ de $]$} & {$[$ mar $]$} \\
\hline
\end{tabular}

A pergunta que cabe nesse caso incomodaria um pouco os defensores do método fônico, que sustentam seu sistema na ideia de consciência fonológica, ou mesmo dos construtivistas, que veem um sujeito ativo e consciente em cada operação criativa: que consciência ou subjetividade mobilizou essa forma semelhante (Valdemar) no lugar da forma dita antes pelo pai (Claudemir)? Para nós, já fica clara aí a presença de uma dimensão inconsciente, de um sujeito intervalar e de um movimento próprio da língua, com seus efeitos metafóricos e metonímicos.

Esse dinamismo da língua, que implica o inconsciente e uma memória textual/discursiva, de fato não condiz com o modelo das duas colunas discutido páginas atrás e, talvez, nenhum modelo, por mais sofisticado que fosse, recobriria as inúmeras possibilidades associativas entre a palavra cotidiana e os textos lúdico-poéticos. Entretanto, vamos adotar aqui um modelo que, por sua complexidade, julgamos mais adequado: a faixa de Moëbius superfície uni(bi)lateral criada em 1858 pelo matemático August Ferdinand Moëbius.

Esse objeto topológico permite pensar que o Eixo $A$ e o $B$, quando parados, estruturados fora da temporalidade, podem formar dois lados de um fenômeno (como a metáfora da folha de papel proposta por Saussure (1960); mas quando em processo, quando no calor da ação, há sempre a possibilidade da interpenetração entre 
eles ${ }^{10}$. Como na ilustração abaixo, criada por Escher, em que as duas formigas trocam de lado sem se darem conta de terem atravessado alguma borda, algum furo.

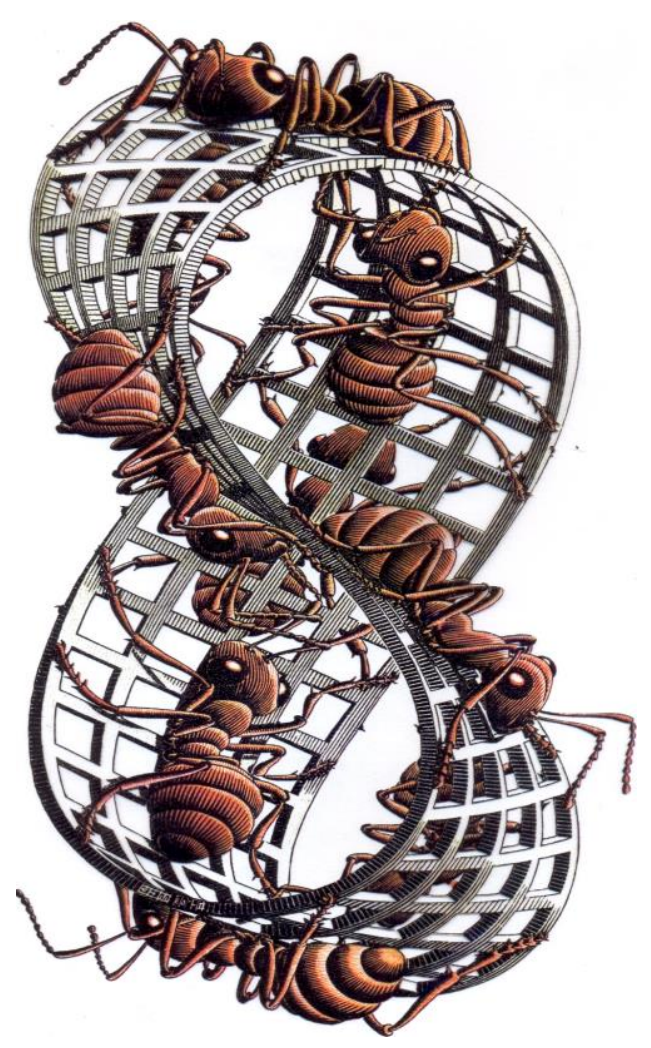

(Escher, 1994 p. 40)

Note que a intenção aqui não é captar todos os fenômenos, mas apenas entender que a qualquer momento, com a língua em processo, as duas dimensões podem convergir para uma única fita alongada. O que é bidimensional se torna unidimensional. Lacan e os lacanianos em geral utilizam a faixa de Moëbius para efetivar suas "mostrações" paradoxais, o modo como o signo cede vez ao significante ou para compreender a interpenetração das cadeias significantes que fazem a dinâmica da língua e do psiquismo.

${ }^{10}$ A faixa de Moëbius comporta paradoxos interessantes: o mais comum reside no fato de se constituir a partir do dois em um; o de haver uma mudança de lado imperceptível quando se faz o seu percurso (o que nos lembra a passagem inconsciente-consciente ou ainda os paradoxos do sonho, por exemplo, o fato de um lugar ser $X$, mas também $Y$ ) e ainda seu corte longitudinal (amplamente explorado por Lacan), por ser um corte que não separa: se cortarmos uma superfície bilateral, temos duas metades, que se coladas fazem um; se cortamos a faixa de Moëbius, o corte resulta em uma fita mais longa, mas com quatro semitorções, e propriedade bilátera. (Granon-Lafon, 1988 p.31) 
Para compreender melhor, retomemos nossos dois eixos de forma dicotomizada, isolando os textos possíveis da fala cotidiana (com função comunicativa) e os chamados lúdicos poéticos (função poética):

na faixa A, elencamos os diálogos cotidianos, as conversas que, em geral, são encaminhadas para orientar as diversas possibilidades de ação entre as pessoas. São os chamados textos comunicativos, diálogos, produções linguísticas que estariam subordinadas à Função Comunicativa e a uma rede discursiva mais ligada à ideia de língua-ação, que podemos também chamar de função pragmática.

Na faixa B, incluímos todos aqueles textos que a tradição veio peneirando, formatando e reatualizando a partir da memória dos pais, dos filhos, das crianças e dos adultos em geral. O que os caracteriza é que eles, em geral (quero dizer, não rigorosamente!), são mais formalizados, mais completos, que os da faixa $A$, além de serem ativados por uma intenção outra, que vai além da utilidade comunicativa. São, como diria Manoel de Barros, "desúteis", ou seja, servem para o "de brinca", para o jogo, para o lazer, enfim, expressam emoções. Quando alguém repete uma parlenda ou canta uma cantiga a uma criança, só espera da criança uma participação jubilosa, esfuziante, alegre, enfim, propõe um enlace marcado pela afetividade, pela emoção. Para que o adulto possa se envolver de fato, suas memórias mais primitivas são acionadas. De onde tiramos, por exemplo, uma brincadeira como o "Serra, serra, serrador" se não de uma memória vivenciada na infância?! Nos ludismos que se dão entre adulto e criança, o que se vê é o reencontro de uma criança do passado (na memória do adulto) com a que está no presente. A produção desses textos se vincula à função poética e eles formam uma rede de memória 
que já enraíza potencialidades para o gosto literário, como mostrou Bandeira.

Em nosso esquema, mesmo no dicotômico, note que é possível dar meia-torção nas duas faixas e as deixarmos com as pontas quase se juntando, significando com isso mesmo que essa divisória entre os eixos só é estanque porque precisamos efetivar didaticamente distinções, mas no processo, no frege dos eventos discursivos, os dois lados podem figurar como apenas um, ou seja, o que aparentava dois fenômenos muito distintos acaba revelando uma dinâmica de encontros entre eles. No entanto, esses encontros podem ser bem marcados, percebidos e apreciados, ou cair no esquecimento. Por exemplo, uma pessoa pode ter sua fala e suas decisões marcadas por alguns provérbios ou adágios, mas não identificar a gênese dessas relações - o que lembra o esquecimento número 1 de Pêcheux (1988 p.173) ou mesmo o recalque freudiano, pois um paciente em análise ao remontar esses fragmentos perdidos, poderia dar um passo importante em sua análise.

Entre um eixo e outro, esses inusitados vínculos intertextuais constituem dinâmicas linguageiras e subjetivas que, como veremos, funcionarão como verdadeiras matrizes sobre as quais se estenderão muitas habilidades linguísticas e discursivas - entre elas, as que aqui mais nos interessam são as que potencializam posições subjetivas que favorecem a leitura significativa, como demonstramos acima. Essa nossa hipótese pode ser assim formulada: apesar das interpenetrações possíveis entre esses dois eixos (função pragmática e função poética), temos aí duas modalidades distintas de uso da língua com possibilidades de dominância de uma ou de outra na infância. Por exemplo, para algumas crianças a fala cotidiana pode se reduzir a imperativos, frases curtas e fragmentadas, muito dependentes do contexto, sempre instruindo ações ou inibições no mundo; para outras, a flexibilidade pode dar o tom, ou seja, haverá 
mais relações com esses textos in absentia. Nesse caso, esse repertório funcionaria como uma rede de facilitação linguageira, que é a base das habilidades exigidas pela escrita, tanto em sua dinâmica de leitura como de produção textual. Isso significaria que a função poética estaria sempre de prontidão, mas dependeria, no entanto, de um posicionamento subjetivo para se efetivar - como veremos mais adiante.

Como mostraremos no capítulo III, temos encontrado em nossas pesquisas alunos que trazem na memória um repertório razoável de textos marcados pela predominância da função poética e outros com repertório mais encurtado e até mesmo quase inexistente. Evidenciaremos que essas diferenças requerem escutas diferenciadas (Belintane, 2010a), sobretudo quando se parte de uma concepção que quer pensar a entrada na escrita facultando possibilidades de posicionamentos subjetivos mais propensos à leitura. Os exemplos que vimos e essa primeira distinção que fizemos têm como objetivo abrir caminhos para um reposicionamento de algumas concepções teóricas da Psicanálise e da Linguística no universo infantil, mais precisamente nas relações de ensino e de aprendizagem (escolares e parentais) que marcam a entrada da criança tanto na língua como na escrita.

\section{(RE)ESBOÇANDO UM PERCURSO TEÓRICO}

Para um educador da área de linguagem é sempre importante saber quais posturas teóricas estruturam esta ou aquela proposta de ensino, mas mais importante ainda é reconhecer que entre teorias e realidades há lacunas e impasses. Não há teoria que se mantenha inabalável diante das diferenças e complexidades que emergem em uma sala de aula situada em seu tempo e lugar. A alegoria da peleja (no interior de São Paulo é o nome que se dá a uma cobertinha curta, 
que não cobre o corpo inteiro, mas que a pessoa acaba se esquentando de tanto pelejar à noite no exercício de cobrir a cabeça e descobrir os pés e vice-versa) deve estar sempre de prontidão no horizonte do educador. A teoria é a cobertinha, nosso jogo de cintura é o pelejar do qual depende o quanto se esquenta.

Como quase todas as concepções gestadas na área de linguagem nas últimas décadas, nossa perspectiva rejeita convictamente a idéia de que a língua seja um mero código consensual que os homens utilizam exclusivamente para a comunicação. Entretanto, marcaremos aqui uma diferença: algum código ou estrutura continua existindo sobretudo no momento em que se isola um elemento para se compreender seu funcionamento por exemplo, como se relacionam os elementos básicos da língua e da escrita: o fonema, a sílaba, a palavra falada e escrita; em outras palavras, ainda se pode, com calma e prevenção, pensar processo e estrutura combinadamente.

Também não caímos na tentação de ver, no funcionamento da língua, apenas as ações construtivas de um sujeito centralizado, que se posta por detrás dos mecanismos linguísticos e, conscientemente, manipula seus elementos a partir de suas tentativas e erros. Do mesmo modo não assumimos, como já se fez muito na pedagogia, em nome de um dinamismo de bom tom, que tudo o que seja passividade deva ser posto de lado como um mal. Tal qual vimos para o par oralidade-escrita, também passividade e atividade se fundem e se separam moëbianamente e, ainda, em nossa concepção, a passagem de uma para outra não é uma mera questão de boa vontade - ou seja, boa parte desses movimentos são inconscientes. Um exemplo é a rápida ligação que Luíza faz entre o que disse a mãe, "você vai quebrar a tigela" e a canção do pato - teria ocorrido aí um esforço cognitivo consciente? A mãe planejara com antecedência esse enlace? Se desse acontecimento discursivo emergiu o sentido da palavra "tigela" pouco se pode dizer, no entanto, o que se pode dizer 
e até se aproveitar no ensino, é que este texto posto antes em sua memória tem uma importância fundamental, pois funciona como uma matriz sensível aos efeitos metafórico-metonímicos - matriz privilegiada, pois em vez de acionar uma outra palavra ou situação cotidiana, remete para um texto completo $e$ instiga um reposicionamento subjetivo de natureza moëbiana: a criança era um sujeito-ação, simplesmente gastando um bom volume de energia, mas de repente aciona-se algo de outra ordem, que baixa o nível energético e engaja a criança na poesia.

Outro elemento importante que já se pode afirmar (e que pretendemos confirmar): faz diferença ter ou não ter um volume de textos na memória, sobretudo desses gêneros da oralidade infantil cujo corpo estético favorece esses reposicionamentos subjetivos. Claro que não pretendemos assumir a ideia de que basta ter textos para que uma subjetividade venha mudar o tom da criança, mas é necessário ter memórias e traquejos discursivos, se quisermos facilitar o caminho para a alfabetização e a entrada na leitura.

Esse desencontro de sentidos entre a fala do adulto e a fala da criança, que é também um encontro, é uma dimensão da língua a que Milner chama dimensão do não-idêntico:

é o equívoco e tudo o que o promove, homofonia, homossemia, homografia, tudo o que suporta do duplo sentido e o dizer em meias-palavras, incessante tecido de nossas conversações (1987, p. 13)

É essa dimensão que permite uma aproximação mais efetiva entre Linguística e Psicanálise. Nesse contexto teórico, nossa concepção encontra apoio também nas pesquisas de Cláudia de Lemos e seguidores - que projetaram no Brasil uma psicolinguística da escuta do equívoco, na dimensão do não-idêntico, balizando seu percurso teórico a partir de seu encontro com a Psicanálise: 
A oscilação entre o outro e a língua - cernidos mais no que a fala da criança fazia ver deles do que por um olhar instrumentado por teorias - se fez sentir nos vários artigos que escrevi até 1992 (ver, principalmente, 1984 e 1982) momento em que encontro na Psicanálise, mais precisamente, em um primeiro contato com a obra de Jacques $L A C A N$, razões para insistir na Lingüística como um afastamento crítico em relação à Psicologia do Desenvolvimento. (2002, p. 50)

De Lemos mostra que a trajetória que engaja a criança como sujeito na aquisição da fala pode ser analisada a partir de uma "escuta", que põe em relevo três posições:

(1) a criança em relação à fala do outro, mas num processo de não-coincidência (aqui se refuta a mera imitação), em que se alternam os fragmentos linguísticos que marcam a alienação (por exemplo, fragmentos vindos diretamente de episódios de fala da mãe, quer da cena linguística da interação, quer de outra acontecida antes) e a separação (que marca mais decisivamente as nãocoincidências de sentido entre a fala da mãe e os fragmentos que reaparecem na fala da criança; por exemplo, a mãe diz "telefone", a criança em vez de repetir o mesmo fragmento diz "alô" - evidenciase aí um processo de subjetivação, assim explicado por De Lemos:

Se o pólo dominante ou convergente da primeira posição é o outro, as relações entre os significantes que vêm do outro dão a ver o funcionamento da língua e um processo de subjetivação por ele regido, isto é, que aponta para um sujeito emergente no intervalo entre os significantes do outro (p. 58) ${ }^{11}$.

11 De Lemos, a partir desse artigo de 2002, incluiu em sua pesquisa o par alienação e separação do Seminário 11 de Lacan (1993) e, com isso, conseguiu um importante avanço no campo da aquisição da linguagem. Em seus trabalhos anteriores prevalecia o par, metáfora e metonímia, como conceito-chave de sua análise. 
(2) na segunda posição, o polo dominante é a língua - observase a emergência subjetiva a partir da análise de erros na repetição de sequências paralelísticas, do tipo:

Episódio 7 (brincando com uma boneca)
eu falo tudo o que eu quero
ela come tudo o que eu quero
ela faz tudo o que eu quero
ela brinca que eu quero
ela brinca que eu faço) -
(Mariana: $2: 9.28$ ) (p. 59 )

Note-se aí que a criança explora a estrutura inicial, mas cruzando outras cadeias, de outros contextos, até chegar a um nonsense com a recombinação de fragmentos já ditos ("ela brinca que eu faço"). A pesquisadora evidencia, neste e em outros episódios, o que esse processo tem de alienação (a criança chega mesmo a interromper uma narrativa por efeito dessas substituições) e o que tem de ganho, pois tais deslocamentos abrem outros sentidos, ....seus enunciados são cadeias permeáveis a outras cadeias e, portanto, passíveis de deslocamento, de ressignificação, de abrirse para significar outra coisa (p. 61).

(3) Na terceira posição, instancia-se uma subjetividade dividida entre o que se fala e o que se ouve, ou seja, a criança percebe não só as reações do interlocutor diante de um enunciado confuso como também refaz por si mesma um erro ou um enunciado pouco claro, como no episódio abaixo:

\footnotetext{
Episódio 11: (Ao contar uma história R. tenta, como diria o linguista, colocar em discurso direto a fala de um personagem)

R: Eu e a Aninha quando crescerem que nem (pausa longa) (retomando) João falou assim: eu e a Aninha quando cresce, crescerem...crescererem...querem sê almirante de navio. (p. 62)
}

De Lemos, em vez de classificar essas alterações como surgimento de uma capacidade metalinguística ou mesmo de um sujeito que progressivamente domina o processo como ocorrem nas 
teorias socio-histórias e gerativistas, prefere antes desvelar aí a emergência de um sujeito em outro intervalo: naquele que se abre entre a instância que fala e a instância que escuta, instâncias não coincidentes...(p. 62)

Ao finalizar seu artigo, a pesquisadora indaga sobre a relação entre os efeitos da língua em si (por exemplo, a criança completando estruturas paralelísticas como um efeito reflexivo da própria língua) e os processos de subjetivação quando se leva em conta o grande Outro como tesouro dos significantes (p. 64). Em outras palavras, a pesquisadora está corroborando, no campo da aquisição, a dinâmica psíquica lacaniana das relações imaginárias (espelhamento com a mãe) atravessadas pelo simbólico (introdução do terceiro elemento sob a égide da função paterna). Nesse contexto, revela também uma diferença entre a criança capaz de produzir mudanças em um estrutura paralelística e outras (psicose, autismo) em que esse jogo metafórico-metonímico parece não ser possível (uso de holófrase, de frases ou expressões inteiras que não se deixam segmentar e intercambiar), o que torna as relações entre posicionamentos e estruturas linguística e psíquica ainda mais complexa.

No Brasil, essa perspectiva de De Lemos é pioneira em aquisição de linguagem, mas já vem sendo retomada também no campo da escrita e de seu ensino: Borges (2006), enfocando o processo de entrada da criança na escrita (alfabetização); Bosco, a relação entre desenho e letra (2002) e a emergência e a função do nome próprio no processo de aquisição da escrita (2009); Oliveira (2009) que analisa a emergência de traços singulares (de autoria) em manuscritos de crianças do ensino fundamental.

Em um artigo intitulado $A$ Alienação e a Separação na Paródia: uma estratégia para a produção de texto com alunos de 9 anos (Belintane, 2009 prelo), aproximamos esses dois conceitos de Lacan da paráfrase e da paródia. Ao longo deste texto, utilizaremos esses 
conceitos, retendo sempre a ideia de alienação na linguagem, ou seja, uma criança pode se alienar na linguagem desde as imagens até, por exemplo, a imagem da letra (quando subvocaliza em demasia, levando um tempo razoável para dela se separar e extrair o conceito, o sentido). O par alienação e separação, no campo analítico, funciona, para Lacan (1993) ${ }^{12}$, como correlatos da metáfora e da metonímia: o efeito de semelhança pode sustentar a alienação, já a mobilidade da metonímia faria o efeito da separação. Toda essa nomeação não deixa de ser uma retomada do par condensação e deslocamento, usado por Freud (1987) na Interpretação de Sonhos ${ }^{13}$.

Como vimos nas páginas anteriores, a criança desde o nascimento está submetida às possibilidades linguageiras dos pais. Cada grito, cada choro, cada gesto infantil será interpretado pelos pais e recoberto por falas, cantos e outras possibilidades da língua; em contrapartida, os acalantos, contos e ludismos linguísticos vão se enredando e constituindo um outro modo de se posicionar na linguagem.

Apesar de os pesquisadores da área de aquisição de linguagem se centrarem demasiadamente sobre o diálogo (adulto-criança; criança-criança), não é difícil reconhecer que o estofo linguístico que envolve a infância é entretecido como uma ampla rede de possibilidades discursivas e textuais. Tanto para a mãe como para o pai, o cabedal linguístico exigido nas relações iniciais com a criança não é apenas aquele extraído do uso comum da língua (função comunicativa), que se atualiza no diálogo. Ao contrário, todos esses jogos linguageiros parecem brotar inexplicavelmente de alguma memória afetiva muito especial, uma memória ativada pela função poética e por uma discursividade que já predispõe uma infância aninhada num amplo e tradicional repertório de textos, que são os gêneros da tradição oral infantil. Notemos abaixo, como Perroni

\footnotetext{
12 O Seminário XI: Os quatro conceitos fundamentais da psicanálise (1964) _

13 Volumes IV e V (1900)
} 
(1992), ao pesquisar a emergência de elementos da narrativa na infância também pôde se deparar com elementos aparentemente inexplicáveis. No diálogo abaixo (com grifos nossos), podemos detectar uma intromissão de um elemento de um conto de fadas na fala da criança (Chapeuzinho Vermelho na versão dos Irmãos Grimm):

(D. procura por um carrinho de bebê)

1. F Não sei onde está.

2.D, Já sei! Deu pro nenezinho da Susana! Sabe quem é?

3. F. Quem é a Susana?

4. É uma moça, amiga da mamãe.

5.F $A$, eu não conheço não.

6. É minha tia.

7. F. Sua tia?

8. É, ela...ela... 'o uma pedra, e...e cortou aqui com a faca, cortou pa tirá a pedra, nasceu uma pedra lá, daí cortou aqui pra tirá a pedra.

10. Nã, aqui.

9. F. A, cortou aí na barriga?

Ela tem um nenezinho. Ela não pode pegar o nenezinho, porque... porque ... porque ela cortou. (D., LXXX, 3,11.28) (p. 138)

Apesar de não explorado pela pesquisadora, que no momento focava a ordenação dos eventos da narrativa/relato, percebemos aí um jogo intertextual revelador: a criança usa o episódio da abertura da barriga do lobo para enfrentar o real insuportável da conversa que está entretendo, os detalhes de uma cesariana. Abrir a barriga evoca o episódio do Lobo, cuja barriga foi aberta pelo caçador e recheada com pedras.

Buscando um esquema para as interações vistas, podemos chamar a instância que põe em jogo a mãe (outro) diante da criança e vice-versa, como eixo eu-outro (Lacan, 1985) ${ }^{14}$. Concordando com a Psicanálise, assumimos que a relação mãe-criança é matricial na formação do psiquismo-linguagem, pois traz o vínculo da alienação para o mundo das relações externas, sujeitando-o à separação. A

\footnotetext{
${ }^{14}$ Seminário II: O eu na teoria de Freud e na técnica psicanalítica (1994=-1995)
} 
entrada de um "pai" na relação é que pode estremecer esse vínculo e abrir possibilidades para uma constituição simbólica que vá além desse aparente espelhamento inicial.

Quando pensamos esses momentos iniciais da vida, levando em conta as figuras parentais concretas, mãe e pai, acabamos criando um jeito meio mecânico de pensar, diríamos que imaginarizado demais. Lacan trabalha com a ideia de função e não com a presença concreta de um pai e de uma mãe. Podemos pensar em função paterna, função materna e a partir daí assumir então que é próprio da função materna abrir a possibilidade de a criança se entregar, se alienar, aos encantos maternais (alimentação, cuidados, manhês, cantigas, carinhos etc.). De outro lado, é próprio da função paterna intervir nessa relação como um terceiro, como uma polaridade que intervém, perturbando, deslocando, descentrando e abrindo o canal da maternância e do universo parental mais geral.

Pensar em função significa ainda deixar aberto o pólo de intervenção, ou seja, outras pessoas ou mesmo instituições podem ocupar esses polos e não necessariamente os pais biológicos e, mais ainda, uma só pessoa pode fazer boa parte do que seria pertinente aos dois polos. Mas aqui é preciso fazer uma distinção. Lacan não era um pensador que se prendia a dicotomias simplórias, vimos sua predileção pela faixa de Moëbius. Então, função materna e função paterna não constituem uma oposição que pode ser diretamente correlacionada ao feminino-masculino e nem mesmo este par corresponderia diretamente a macho e fêmea (Lacan, 1985). A mãe, por exemplo, pode instituir uma relação que traz para o jogo tanto a função materna como a paterna. Toda vez que uma mãe tira o peso de sua presença ostensiva sobre a criança, provocando alguma falta, podemos dizer que há aí a influência de um terceiro pólo que desloca a pregnância maternal e permite um espaço para que o bebê abra uma janela nesse útero imaginário. Por outro lado, quando um homem (sobretudo os maridos contemporâneos) se posiciona ao lado 
da criança com uma voz doce, cantando uma cantiga ou trocando fraldas, pode-se ver aí um reposicionamento subjetivo em relação às posturas mais fálicas do passado, ou seja, o papel social já não é o mesmo, mas a maternância, compreendida moëbianamente, continua, na essência, a mesma. Lacan utiliza o seguinte esquema para ilustrar essas relações:

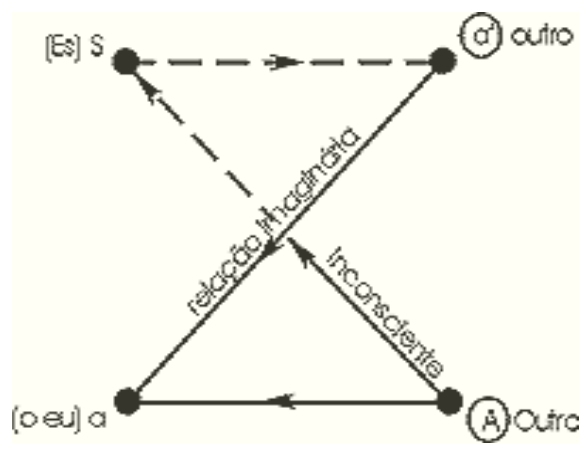

Esquema L (Lacan, $1985^{15}$ p. 307)

Note que no eixo $\mathbf{a} / \mathbf{a}^{\mathbf{1 6}}$ " entrevemos a função materna e no eixo $A / S(E S)$ a função paterna. Do entrecruzamento desses eixos, desloca-se o que chamamos aqui sujeito barrado ou mesmo sujeito dividido (S) ou do Inconsciente (Es - pois Lacan parte da famosa frase de Freud - Wo Es War, sol Ich Werden ${ }^{17}$ )

O que barra este sujeito? O que o descentra de suas certezas? Não é outra coisa senão o outro que tensiona a mãe, a figura paterna com tudo o que representa no psiquismo da mãe: o amor, a lei, a palavra.

\footnotetext{
15 Seminário 2 : "O Eu na teoria de Freud e na Técnica da Psicanálise" (1954-1955) 16 Poderíamos ter utilizado a letra $\mathbf{0} / \mathbf{0}$, pois se trata da letra inicial da palavra outro/Outro, mas achamos interessante utilizar a fórmula original de Lacan a/A (de /autre/Autre = outro/Outro em francês), porque é assim que os leitores encontrarão em outros livros.

17 Lacan dá dois sentidos a esta frase: tomem-no (o seu S, sujeito excêntrico) como sendo a letra S. Ele está aí, ele está sempre aí. É o sujeito. Ele se conhece ou não se conhece. Isto nem sequer é o mais importante - ele está ou não está com a palavra. No fim da análise, é ele quem deve estar com a palavra, e entrar em relação com os verdadeiros Outros. Ali onde o S estava, já tem que estar o Ich. ( $\mathrm{p}$. 311). Sabemos que Lacan mudará essa perspectiva em suas obras posteriores, nas formulações finais não haverá essa passagem, mas sim a ideia de que é o sinthoma em si que passa a ter um papel crucial na amarração das dimensões do psiquismo (Seminário XXIII); no entanto, para o nosso objetivo, essa concepção de sujeito (e também a de significante) é ainda produtiva e interessante.
} 
Talvez aqui possamos criar uma imagem para facilitar as possibilidades de interação que queremos realçar:

- A criança, por ser gestada no útero, por ser parte do corpo materno, ao vir ao mundo ainda mantém as sensações primárias desta ligação umbilical. O corte do cordão, tanto para o bebê como para a mãe, não representa de imediato o corte psíquico. Podemos notar isso ao constatar que, no mundo do lar e da vida, não existe apenas o bebê para a mãe cuidar. Como mulher, ela também está implicada na relação conjugal e em outras dimensões da vida (trabalho, estudo, diversões etc.). Sua relação com o bebê tende, portanto, a perder a pregnância, ou seja, é como se em seu psiquismo se fosse abrindo um espaço entre ela e o bebê e, nesse eletrizado hiato, a figura paterna e as demandas externas estivessem lá como uma lembrança de que a maternidade não é um exercício exclusivo: estaria aí o jogo da alienação e da separação. O pai, apesar de não exercer a possibilidade biológica da gestação, pode exercer - mesmo que não queira ou mesmo estando ausente - essa intromissão psíquica, ou seja, figurar como aquele que atravessa o eixo da relação mãe-criança tanto na vida cotidiana como no próprio psiquismo da mãe. Nesse contexto, sua presença metafórica se põe como uma potência - essa potência é também chamada metáfora do falo, ou seja, elemento marcante da diferença sexual. Paradoxalmente, é potência porque institui um vazio operante. Finalizemos nossa alegoria com uma correção: o pai, na ótica imaginária e simbólica da mãe, ultrapassa o ser real em si e se reveste de uma alteridade outra, ou melhor dizendo, do Outro, do simbólico, da linguagem.

Apesar de, como já o dissemos, Lacan ter avançado em sua concepção de sujeito ao longo das décadas de sessenta e setenta e de os lacanianos e pós-modernos (Dufour, 2005) localizarem certa crise da função paterna e das instituições tradicionais, a ideia de descentramento e de alienação na linguagem continuam como 
importantes e indispensáveis. Para as nossas formulações pedagógicas, o sujeito dividido pela e na linguagem inspira uma compreensão mais aprofundada, por exemplo, das relações de atividade e passividade, sobretudo quando consideramos o modelo que aqui estamos discutindo: uma subjetividade de permeio, cindida entre uma fala pragmática, cotidiana, e outra poética e literária.

Essas contribuições da psicanálise são também cruciais para ampliarmos nossa visão da língua. A partir deste modelo, podemos pensar que a criança é atraída pelos jogos linguageiros da função materna, trocando as possibilidades do gozo imediato do corpo (mamar, carinho, estar ao colo etc.) pelas vozes da mãe (manhês, cantigas, brincadeiras com palavras etc.). A título de ilustração, imaginemos a criança gritando no berço, exigindo algo da mãe. Esta vem e interpreta esse grito, atribui a ele um sentido, mesmo sem saber se interpretou certo ou errado. Em razão dessa incerteza recorre a uma diversidade de tentativas: alimentação, carinho, manhês e acalantos, até que a criança durma. Ao longo do tempo, quaisquer resmungos emitidos espontaneamente pela criança serão interpretados pela mãe, que vai tentando atribuir a esses fragmentos quase inarticulados o estatuto de palavra: a criança diz "ô" ou então "bô", ao terminar a mamadeira, a mãe emenda por cima: "é sim, acabô!" O movimento de atribuição de sentido e de expansão dos signos parte então desse outro, mas também à revelia dele podemos dizer que os equívocos e nonsenses se fazem presentes e são fundamentais nessa equação. Então, em resumo: nessa operação de divisão subjetiva, a polaridade do sentido vai se formando e juntamente com ela ficam ali os traços do sem-sentido (nonsense) que estiveram presentes no próprio ato de fundação da palavra. Nonsenses que tendem a permanecer ligados à subversão (ao puro prazer de emitir sons), que fisgam sentidos inusitados ou mesmo que se perdem no real da língua (Milner, 1987). O que dizer, por exemplo, da nomeação de uma demanda da criança, do tipo "mamãe 
te quero", mas sendo nomeada como "a mamadeira já vai" ou, então, "vou te contar uma história". O equívoco, essa falta de correspondência tem importância estrutural, por deixar seu resto, seu vazio de sentido.

Podemos dizer também em relação à linguagem que bem ali na faixa da fala séria, atravessando-a, está a faixa do nonsense, da brincadeira e também a das possibilidades poéticas. Quando um poeta, como Murilo Mendes, distorce o sentido de uma palavra, como é o caso do verbo "demolir" no excerto abaixo, podemos dizer que ele possibilita uma mobilidade significante a partir desses destrilhamentos que fazem essa dialética do senso e do não-senso.

Demoliram uma mulher

a sons de clarinete ${ }^{18}$

Quando nos deparamos com a forma verbal Demoliram, o senso lógico nos põe diante de algumas possibilidades: demoliram casas, prédios, edifícios?! No entanto, ao encontrarmos o complemento inusitado uma mulher, é inevitável o sobressalto; mas de imediato já acionamos nosso conhecimento poético e aí um fenômeno curioso se dá: esvaziamos o sentido consensual da palavra demoliram e deixamos entrar toda a atmosfera sedutora da palavra mulher, ou seja, erotizamos a linguagem. O verso seguinte só vem confirmar que essa demolição não se deu a golpes de marretadas, mas com a melodia sedutora da clarineta. E aí se depreende, neste ato de ler e na própria proposta do poeta (e dos poetas em geral), o ato de esvaziar, ou seja, jogar fora o sentido de uma palavra para que outro venha sobre ela se assentar. Ao longo desse trabalho, veremos que esse ato de esvaziar é uma operação fundamental da

${ }^{18}$ Excerto do poema "A fatalidade" Murilo Mendes (1945) 
linguagem e da leitura ${ }^{19}$, mas que nem sempre o ser falante o tem de prontidão, sobretudo na escolarização da leitura.

É por este viés do "esvaziamento", da permuta de formas e sentidos, que enxergamos as cantigas e os jogos linguageiros da infância como matrizes textuais da leitura e da própria literatura. É como se os dois eixos (comunicativo e poético) mantivessem um acordo tácito: vamos esvaziar as palavras do cotidiano e deixar que outros sentidos tomem as rédeas de nosso jogo, então, o sapo cururu do açude da Penha e o da cantiga citados por Graciliano podem até entrar em cadeia associativa, intertextual, mas um não se reduz ao outro, o da cantiga é personificado, canta e sente frio como o menino Graciliano. Também nesse eixo vamos amarrar nossas conexões conceituais que vão desde a fala infantil à poesia, à literatura, passando pelos jogos linguageiros de todas as idades (brincadeiras, chistes, piadas etc.) e ainda vamos discutir as relações entre imagem e palavra.

Neste momento, cabe aqui uma reflexão sobre duas dimensões da língua, para melhor situar o universo infantil. Colocamos em jogo o conceito lacaniano de lalangue (comumente traduzido por alíngua). No termo lalangue encontramos a lalação infantil ${ }^{20}$ - aquela reduplicação de sílaba ou ainda os prolongamentos sonoros de vogais e até mesmo a intervenção de um ou outro ruído próximo das consoantes que o bebê produz, sobretudo quando está sozinho em seu berço. O lala do termo francês nos indica que estamos nos referindo a uma dimensão das possibilidades da linguagem em que o

\footnotetext{
19 Iser (1996) e outros autores de Estética da Recepção utilizaram essa mesma ideia de vazio para a leitura e o efeito estético, embora possamos dizer que ela é tributária da psicanálise, pois o conceito se estabelece desde as primeiras obras de Freud.

${ }^{20} \mathrm{Je}$ fais lalangue parce que ça veut dire lalala, la lallation, à savoir que c'est un fait que très tôt l'être humain fait des lallations, comme ça, il n'y a qu'à voir un bébé, l'entendre, et que peu à peu il y a une personne, la mère, qui est exactement la même chose que lalangue, à part que c'est quelqu'un d'incarné, qui lui transmet lalangue. (Jacques Lacan: Conférence donnée au Centre culturel français le 30 mars 1974). In. http://psicanaliselacaniana.blogspot.com/2009/02/lalingua-ou-alinguapequeno-percurso.html (consulta em julho de 2011)
} 
sentido consensual fracassa e por fracassar vai permitir a possibilidade dos jogos linguageiros, como disse Milner (1987), alíngua é, em toda língua, o registro que a consagra ao equívoco ( $p$. 15).

Talvez seja por esse percurso entre língua-alíngua, quase que recobrindo os termos infância-adulto, que alguns falantes usam a interessante expressão para defender o uso sério da língua: - Não sou mais criança, fale sério! Expressão essa que não deve ter muito valor para o pai, mãe ou educador que cuida de uma criança ou mesmo para o indivíduo brincalhão que não gosta de perder a oportunidade de um chiste, de uma piada, de uma gozação.

E o sujeito? Como fica neste contexto? Perfila-se ao lado da língua instrumental, do sentido consensual, ou do lado da equivocação, dos nonsenses e dos jogos?

Vimos em nossos exemplos que há um modo de usar a língua que o eu, a cognição, não tem poder de controle, visto que os sentidos só encontram sua fonte no espaço de cisão entre o outro (função materna) e o Outro (função paterna) e são permeados por um constante não-saber, por uma falta. Se existe alguma causa para o sujeito, esta seria um vazio, uma falta. É neste sentido que se trata de sujeito do desejo inconsciente. A linguagem usual, sem que "pegue delírio"21, está conformada ao ego-imaginário e é entre significantes que emergem na fala que o sujeito pontua seus sentidos fortuitos:

O sujeito não é outra coisa - que ele tenha ou não consciência de que significante ele é efeito - senão o que desliza numa cadeia de significante. Este efeito, $o$ sujeito, é o efeito intermediário entre o que caracteriza um significante e outro significante, isto é, ser cada um, ser cada qual, um elemento (1985, p.68).

No exemplo de Rafaela, o signo "que-se-chama", pura holófrase, efeito de alíngua, torna-se um significante, um S1, que

\footnotetext{
${ }^{21}$ Manoel de Barros. (1993 p. 15)
} 
remete a "solidão", S2, desvelando uma verdade que entremostra uma subjetividade desejante, que nomeia seu urso de brinquedo acumulando o prazer da cantiga ouvida dias antes. Sabemos que quando um adulto se predispõe a cantar uma cantiga para uma criança, está entrando no jogo da demanda, pois esta criança aprendeu a deixar a mãe em paz em função de outras coisas, entre elas, de uma cantiga. Os fragmentos que vêm dessa cantiga (ou mesmo aqueles que tanto nos fazem errar nas letras de música ${ }^{22}$ ) retornam como significante, sonoridade recheada de outra coisa, de outro contexto, que vai além de seu significado. Talvez seja por isso que Lacan (1985), no seminário XX, quando trata do conceito de "lalangue", diz:

A linguagem, sem dúvida, é feita de alíngua. É uma elucubração de saber sobre alíngua. Mas o inconsciente é um saber, um saber-fazer com alíngua. E o que se sabe fazer com alíngua ultrapassa de muito o de que podemos dar conta a título de linguagem (p. 190)

Baseados na reflexão acima, podemos ampliar a formulação algorítmica do intervalo lacaniano (S1-S2), incluindo outras divisões que parecem consentâneas à própria linguagem, já que esta cisão não ocorre somente entre um significante e outro ${ }^{23}$, mas também entre textos, entre linguagens (oral e escrita), entre meios (gráfico e digital) e entre discursos. O importante a compreender é que um elemento metonímico toma as rédeas do processo (que pode o fazer também pela via da metáfora), ou seja, um elemento ou outro condensará os sentidos para que ocorra a remissão a um outro

\footnotetext{
22 Como a famosa alteração na letra de Jorge Vercillo, Tocando B. B. King sem parar! que acaba subvertida em "Tocando de biquíni sem parar".

${ }^{23}$ É preciso entender que o significante lacaniano é elemento de uma cadeia, mas é sobretudo elemento metonímico que está para uma experiência vivida ou fantasiada, como, por exemplo, a cruz está para a crucificação. Nossa ampliação para outros intervalos (sujeito de entre-texto, de entre-meios) é uma estratégia que visa manter a ideia de uma subjetividade excêntrica, por exemplo, diante do fenômeno da leitura, quando uma criança utiliza ou não seus intertextos para deflagrar um fluxo significativo e uma compreensão singular.
} 
(com)texto, tendo claro que a condensação implica o esvaziamento do signo para que ele se ceda sua materialidade a outros sentidos). Mas o contexto, como mostramos, pode ser um texto inteiro, como no caso que analisamos, uma cantiga.

Tomemos um exemplo hipotético no mundo adulto para expandir um pouco mais essas reflexões: imaginemos que um executivo, em uma importante conferência sobre a exportação de cacau para a indústria de chocolate, caindo numa madorra preguiçosa, deixa-se levar por uma associação que traz de volta um antigo jogo lúdico de sua infância:

"Adoletá, lê peti, lê tomá Lê café com cocholat"

Podemos dizer que o sujeito poderia ser inferido como um efeito entre esses dois discursos, entre a fala dos seus pares, séria, concentrada e este outro estranho que veio, por efeito de alíngua, parear com o que sobrou do discurso do comércio. Não vemos muitas diferenças entre esse executivo quase sério e a associação feita pelas crianças em nossos exemplos reais. Se o executivo soubesse interditar de permeio essa intrometida associação, teríamos aí uma subjetividade de entre-texto bem interessante, criativa, produtiva, que talvez pudesse mudar o chato rumo da palestra dos homens sérios e fazer vir à baila uma idéia nova ou, no mínimo, daria uma lufada refrescante no ar pejado da sala. Claro que interditar é, para ele, mais seguro, ajuda a manter o emprego e a compor seu semblant de homem sério.

Essa pequena alegoria do executivo ajuda-nos a estabelecer a diferença entre nossa concepção (que leva em conta a temporalidade infantil dos modos de posicionamento da subjetividade ou a possibilidade de emergência do nonsense como elementos fundamentais do conhecimento ou dos modos de saber) - das concepções desenvolvimentistas. O mesmo exemplo talvez não 
coubesse nem mesmo na concepção enunciativa de Bakhtin, pois o que se levaria em conta é a interação da consciência do executivo (que no momento poria em jogo uma memória discursiva forjada em outros eventos e experiências discursivas) com as palavras do conferencista, contextualizadas na dimensão discursiva do gênero em questão (conferência). Essa consciência, com seu repertório discursivo que está ali de prontidão para entrar em contato com o discurso do outro, já teria sido redimensionada por outros discursos e palavras anteriores, já teria passado por três processos: pela recepção de palavras alheias, pelas palavras próprias-alheias (pois a tensão de outras palavras alheias faria esse efeito) que, finalmente, tornar-se-iam palavras próprias (compondo sua subjetividade singular. Se o nonsense e as memórias infantis irrompessem, seriam considerados irrelevantes.

Na visão da psicanálise, o esforço de ficar concentrado nas palavras e interpretá-las tem, por detrás, demandas outras que também implicam uma subjetividade inconsciente. Como diz Lacan ainda no Seminário $X X$, essa submissão ao conhecimento implica também uma economia de gozo, um balizamento fálico.

Aproximando Lacan (1985), Foucault (1996) e Pêcheux (1988), podemos dizer que a tal língua séria, essencialmente comunicativa, seria matriciada por discursos que vieram se fazendo muito antes do momento em que o falante a põe em jogo, ou seja, a língua séria deixa prontos seus modelos com o objetivo de evitar o acaso, o imprevisto, o equívoco, os laços de alíngua. No caso, o executivo que se deixou levar pelo Adoletá faria todos os esforços para barrar essa intromissão subjetiva, excluí-la para que a voz do outro fizesse seu efeito de seriedade - ou seja, a loucura, a infância e derivas persistentes constituem, estruturalmente, elementos contingenciais do processo. Mesmo os esforços estariam vinculados a seu assujeitamento discursivo ou às demandas parentais da infância, o que significa que todas as suas interações discursivas não 
produziriam uma síntese singular, livre, autônoma, capaz de manejar conscientemente o mundo sem o peso do passado.

A tabela abaixo mostra, no nível da língua, um pouco dos cuidados com as bordas da discursividade. Uma pessoa poderia tê-la nas mãos em uma reunião de executivos e combinar as colunas para produzir falas que soam bem nesses ambientes tão sérios. Com um pouco de experiências em manejá-las, esses fragmentos estratégicos soariam como pessoais, singulares, desde que nenhum outro significante, acaso discursivo ou deriva viesse se imiscuir entre essas linhas e colunas: 


\begin{tabular}{|c|c|c|c|}
\hline $\begin{array}{l}\text { PREZADOS } \\
\text { COLEGAS }\end{array}$ & A EXECUÇÃO DESTE PROJETO & NOS OBRIGA À ANÁLISE & $\begin{array}{l}\text { DAS NOSSAS OPÇÕES DE } \\
\text { INVESTIMENTOS FUTUROS }\end{array}$ \\
\hline $\begin{array}{l}\text { NUNCA É DEMAIS } \\
\text { INSISTIR QUE }\end{array}$ & $\begin{array}{l}\text { A COMPLEXIDADE DOS ESTUDOS } \\
\text { EFETUADOS }\end{array}$ & \begin{tabular}{|l} 
CUMPRE UM PAPEL \\
ESSENCIAL NA FORMULAÇÃO
\end{tabular} & $\begin{array}{l}\text { DAS NOSSAS METAS FINANCEIRAS E } \\
\text { ADMINISTRATIVAS }\end{array}$ \\
\hline $\begin{array}{l}\text { É FUNDAMENTAL } \\
\text { RESSALTAR QUE }\end{array}$ & A EXPANSÃO DE NOSSA ATIVIDADE & $\begin{array}{l}\text { CUMPRE SEMPRE UM PAPEL } \\
\text { ESSENCIAL NA FORMULAÇÃO }\end{array}$ & $\begin{array}{l}\text { DAS NOSSAS METAS DE PARTICIPAÇÃO } \\
\text { GERAL }\end{array}$ \\
\hline $\begin{array}{l}\text { NÃO PODEMOS } \\
\text { ESQUECER QUE }\end{array}$ & $\begin{array}{l}\text { A ATUAL ESTRUTURA DA } \\
\text { ORGANIZAÇÃO }\end{array}$ & $\begin{array}{l}\text { EXIGE PRECISÃO E } \\
\text { DEFINIÇÃO }\end{array}$ & $\begin{array}{l}\text { DOS CONCEITOS DE PARTICIPAÇÃO } \\
\text { GERAL }\end{array}$ \\
\hline DO MESMO MODO, & $\begin{array}{l}\text { O NOVO MODELO ESTRUTURAL } \\
\text { AQUI PRECONIZADO }\end{array}$ & $\begin{array}{l}\text { AUXILIA A PREPARAÇÃO } \\
\text { E A ESTRUTURAÇÃO }\end{array}$ & DAS NOSSAS PROPOSIÇÕES \\
\hline $\begin{array}{l}\text { A EXPERIÊNCIA } \\
\text { EVIDENCIA QUE }\end{array}$ & $\begin{array}{l}\text { O DESENVOLVIMENTO } \\
\text { DE FORMAS DISTINTAS } \\
\text { DE ATUAÇÃO }\end{array}$ & $\begin{array}{l}\text { CONTRIBUI PARA A CORRETA } \\
\text { DETERMINAÇÃO }\end{array}$ & $\begin{array}{l}\text { DAS ATITUDES E DAS ATRIBUIÇÕES DA } \\
\text { DIRETORIA }\end{array}$ \\
\hline POR OUTRO LADO & $\begin{array}{l}\text { A CONSTANTE DIVULGAÇÃO DAS } \\
\text { INFORMAÇÕES }\end{array}$ & $\begin{array}{l}\text { ASSUME IMPORTANTES } \\
\text { POSIÇÕES NA DEFINIÇÃO }\end{array}$ & $\begin{array}{l}\text { DAS OPÇÕES BÁSICAS PARA } \\
\text { IMPLEMENTAÇÃO DE NOVAS } \\
\text { POSSIBILIDADES DE ATUAÇÃO }\end{array}$ \\
\hline UMA VEZ QUE & $\begin{array}{l}\text { A CONSOLIDAÇÃO DOS DADOS } \\
\text { CONJUNTURAIS }\end{array}$ & FACILITA A DEFINIÇÃO & $\begin{array}{l}\text { DAS CONDIÇÕES APROPRIADAS PARA O } \\
\text { NEGÓCIO }\end{array}$ \\
\hline MESMO QUE & $\begin{array}{l}\text { A ANÁLISE DA SETORIZAÇÃO DAS } \\
\text { EXPERIÊNCIAS }\end{array}$ & $\begin{array}{l}\text { PREJUDICA A PERCEPÇÃO } \\
\text { DA IMPORTÂNCIA }\end{array}$ & DOS ÍNDICES PRETENDIDOS \\
\hline $\begin{array}{l}\text { O INCENTIVO AO } \\
\text { AVANÇO } \\
\text { TECNOLÓGICO, } \\
\text { ASSIM COMO }\end{array}$ & $\begin{array}{l}\text { O INÍCIO DO PROGRAMA DE } \\
\text { FORMAÇÃO DE NOVAS } \\
\text { ATITUDES }\end{array}$ & $\begin{array}{l}\text { OFERECE UMA BOA } \\
\text { OPORTUNIDADE DE } \\
\text { VERIFICAÇÃO }\end{array}$ & DAS FORMAS DE AÇÃO \\
\hline
\end{tabular}


Até aqui procuramos mostrar que a entrada do infans na língua dá-se a partir da emergência de uma subjetividade de entre-textos com todas as possibilidades de interferências de antigas camadas discursivas e de modos do sujeito se posicionar. Para as intenções de nossa pesquisa em educação, o desútil estará sempre no calcanhar do útil.

Também fizemos questão de demarcar uma flexibilidade interessante entre as possibilidades de uma fala comunicativa e os jogos e textos permeados pela função poética. Mostramos que, em vez de oposição entre esses dois eixos, assumimos uma impregnação mútua de ordem moëbiana. Sendo assim, também podemos pensar em um movimento subjetivo entre os dois lados da faixa, ou seja, de repente, uma palavra ou expressão subversivamente traz consigo um texto lúdico-poético.

Se nossa concepção de sujeito, de um lado, é tributária do inconsciente estruturado como linguagem de Lacan; se assume a ideia de excentração e o esquema de alteridade de sua psicanálise, por outro, não deixa de ousar um pouco ao sair de um eixo de conceito que tem a clínica como meta ${ }^{24}$ e a intenção de posicionar a psicanálise como ciência. Boa parte do esforço de Lacan toma esse rumo, ou seja, o da construção de uma linguagem matemática como forma de expressar os fenômenos do inconsciente por meio de matemas e das construções topológicas. Para nós, o inconsciente linguageiro comporta uma outra cisão fundamental - que não dispensa a dimensão de alíngua, ao contrário, a convoca - que é esta que mães, pais e a própria cultura produziram ao longo do século, que divide-unifica (moëbianamente) a fala cotidiana e a oralidade, que põe em jogo a função comunicativa e a poética, também moëbianamente.

\footnotetext{
${ }^{24}$ A clínica como meta exclusiva da elaboração teórica pode levar a concepções como a de Násio (1993), que vê o inconsciente como um fenômeno entre dois, ou seja, só há inconsciente entre paciente e analista.
} 
Em contrapartida, veremos no capítulo III que a filiação teórica que busca uma "consciência" vigilante e pronta para tornar seu o discurso circulante em seu meio (universo de letramento), constitui a base de um grande consenso que influencia o ensino de Língua Portuguesa no Brasil. $O$ ideal de que o ensino se dirige a uma subjetividade ativa ou a uma consciência vigilante engendrou, sem querer, um estranho pragmatismo, que chega a empurrar o texto literário para as sombras em nome dos textos que advêm de um tal "universo de letramento", que é comumente entendido como a escrita circulante do universo do aluno (publicidades, logomarcas, receitas culinárias, textos instrucionais e outros). Como veremos no capítulo II, com Ortega y Gasset (critico do pragmatismo), esse sentido meramente utilitário superpõe o mundo adulto sobre o infantil, sufocando a ninez poética e criativa.

\section{DA ORALIDADE AO OUTRO DA ESCRITA.}

Outro balizamento importante para a nossa abordagem é o fato de concebermos fala e leitura, oralidade e escrita, imagem e letra também moëbianamente. Do mesmo modo que instituímos essa relação para a função comunicativa e a função poética, também usaremos o mesmo modelo para esses pares. Isso quer dizer que, em nossa concepção, a escrita, apesar de utilizar um suporte diferente da fala, não deixa de ser uma manifestação da linguagem, do funcionamento simbólico, o que nos põe diante de uma concepção de leitura próxima à de De Lemos (1998, p. 21), ou seja, compreende-se a entrada da criança na escrita pelo mesmo viés discursivo que permitiu sua entrada na fala, embora sempre levando em conta que não se trata de oposição entre a fala como aquisição natural e a escrita como aprendizagem de uma representação secundária. 
Entre os trabalhos orientados por De Lemos, destaca-se, neste campo da aproximação entre oralidade-escrita, o de Borges (1995), que também concebe a oralidade e a escrita como manifestações da linguagem e não como secundaridade representativa, visão que costuma marcar o campo mesmo nas teorias cognitivistas como a de Emília Ferreiro e de Ana Teberosky (1989) ${ }^{25}$. A diferença entre nossa abordagem e a elaborada por Borges em seu doutorado se dá no recorte do objeto. Borges, apesar de considerar oralidade e escrita como processos que, embora mantendo suas diferenças, podem ser abordados como fenômenos originários de uma mesma dinâmica constitutiva, põe seu foco nas produções escritas de crianças. Já nossa visão busca as diferentes possibilidades subjetivas que a dinâmica discursiva dos diferentes gêneros orais da infância permite, quando a criança entra em contato com a dinâmica visual e simbólica da escrita. Cada gênero originário da cultura oral, desde que retomado em sua performance oral (se é um conto, então será ouvido e recontado; se é uma cantiga, então será cantada, de tal modo que o texto seja memorizado ou, em caso de provir da própria memória do aluno, seja reatualizado), traz importantes elementos estéticos e linguageiros que favorecem a alfabetização e a leitura significativa (é o que mostraremos nos capítulos II e III)

No estado da arte atual, contamos com diversos pesquisadores que consideram o par oralidade-escrita de forma não dicotômica, Marcuschi (2000), Tfouni (1997, 2001, 2008), Gnerre (2003), Correia (2004) entre outros. Nossa concepção guarda uma proximidade maior com as pesquisas de Tfouni, não só por sua compreensão de que se pode falar em letramento mesmo quando se trata da produção oral de pessoas não alfabetizadas, mas também por...

25 É preciso reconhecer que as pesquisas de Ferreiro e Teberosky e de outros cognitivistas não se filiam a uma concepção simplista de representação na qual prevaleceria a correlação direta entre grafema e fonema. No entanto, a concepção construtivista não deixa de afirmar o caráter de representação da escrita em relação aos elementos da fala (significantes e significados) - a escrita continua sendo um segundo sistema, a ser construído pela criança. 
...considerar que tanto pode haver características de língua oral na escrita, quanto vice-versa, ou seja, o que está em questão não é se o sujeito é alfabetizado ou não, mas antes em que medida esse pode ocupar a posição de autor (2001, p.82)

Nosso foco insiste, portanto, em desvelar uma subjetividade que se posiciona entre diversos tipos de textos estruturados pelo grande outro da tradição, a partir de procedimentos estéticos tipicamente orais (jogos linguageiros), que, em nossa opinião, constituem as bases para que a escrita seja assimilada e, ao mesmo tempo, inserida como uma importante possibilidade de expressão e meio de manifestação dos usos da língua. A afinidade que a criança tem com esse universo discursivo da oralidade expande-se com mais facilidade para o campo da literatura e das artes do que para os do ambiente imediato de letramento, que exigem posicionamentos e legitimações outras.

Neste ponto nossa abordagem se avizinha a um paradoxo: se as bases linguageiras da oralidade são também as matrizes fundamentais para a aquisição da escrita, como entender as imensas dificuldades que a educação experimenta para alfabetizar crianças na escola pública? Se de fato as crianças tiveram na infância um verdadeiro enredamento discursivo-textual, se foram compelidas por meio de metáforas e metonímias a constituir uma subjetividade de entre-texto, por que muitas delas não leem ou leem de forma precária? Como se dá esse enlace entre fala e escrita, entre oralidade e leitura? Como a escolarização atravessa a infância com sua proposta de ensinar a escrita? Seria possível detectar na aprendizagem da escrita situações que não favoreceriam a emergência dessa subjetividade de entre-textos? Como se dá a conjunção entre a oralidade advinda dos meios parentais e a escrita proposta pela escola? Conjunção ou conflito? Haveria modos de usar 
a língua e a oralidade que não favoreceriam a entrada da criança na escrita?

Para enfrentar essas questões, na parte seguinte, pretendemos buscar uma outra vertente de pesquisa, oriunda da historiografia da escrita (Février, 1948; Gelb, 1976), que apesar de não ter afinidades teóricas com a psicanálise, parte dela já forneceu subsídios importantes para Freud (1988), Lacan (2003), Safouan (1987), Pommier (1993), Alouch (1995) e outros. Além da história da escrita, retomaremos também os estudos da chamada equação oralidadeescrita (Havelock, 1995), ou seja, as contendas e aproximações entre as culturas orais e grafocêntricas, discutidas, entre outros, por Havelock (1995; 1996a; 1996b; 1996c); Ong (1998); Olson (1995, 1997), além de alguns historiadores da leitura (Chartier, 1996, 1999; Manguel, 1997; Cavallo e Chartier, 1998; Gnerre, 1998). 
PARTE II - ESCANSÕES DA VOZ E DA ESCRITA

Para Lacan (2003) ${ }^{26}$ a escrita é uma decorrência do próprio funcionamento do psiquismo $e$, se a tomarmos em seus fundamentos, não se poderia dizer com tranquilidade que ela suceda cronologicamente a fala - como consensualmente assumem boa parte dos historiadores da escrita. Deixar marcas em superfícies externas ou mesmo internas ao corpo e retomá-las mais tarde como significantes que podem ser relidos é característica geral do ser humano:

A escrita como material, como bagagem, esperava - em seguida a um processo sobre o qual retornarei: o da formação, diremos da marca, que hoje encarna esse significante de que vos falo - a escrita esperava para ser fonetizada, e é na medida em que ela é vocalizada, fonetizada como outros objetos, que a escrita aprende, se posso assim dizer, a funcionar como escrita." (p. 93)

O que Lacan quer dizer com esse aparente disparate? Que escrita é essa que esperava para ser fonetizada? Os exemplos dados páginas antes nesse mesmo seminário já aponta certo caminho: o rébus como estratégia central das escritas antigas que permite transformar uma imagem em som é um dos fundamentos dessa reflexão, sobretudo quando levamos em consideração que essa imagem será apagada e estilizada, resumindo-se a nada mais do que um traço diferencial que permitirá ler um som e olvidar a antiga relação de significado que originou essa letra - o exemplo mais citado é o da letra A, cuja origem seria o esboço da cabeça do boi, em semítico, por exemplo, seria o Aleph.

Lacan recorre às escritas cuneiformes, egípcia e chinesa para evidenciar os processos básicos de qualquer escrita: (1) substituir a

${ }^{26}$ A identificação: Seminário 1961-1962 
coisa representada, (2) apagar a imagem da coisa e se tornar traço; (3) possibilidade de ser lida como um significante (ou seja, um traço que evoca um som cujo sentido pode evocar um outro significante e implicar um sujeito em vez de simplesmente significar).

Se a escrita parece escandir o contínuo dos sons humanos em representantes fonéticos (letras) e para isso usa uma materialidade externa (o suporte e a própria figurabilidade da letra), a voz também porta a mesma dinâmica: no espaço entre o isso e o eu, a língua arma seu jogo de fisgar "pensamentos", mas ao mesmo tempo se deixa marcar por ideias não percebidas, investidas de um outro lugar (do inconsciente):

Finalmente, chegamos ao ponto em que o papel das representações-de-palavras se esclarece por completo. É por seu intermédio que os processos internos se tornam percepções. Tudo se passa como se a seguinte afirmação se comprovasse: todo o conhecimento provém de percepções externas. Quando uma camada adicional de investimento de carga é superposta ao pensar (Denken), os pensamentos serão, então, percebidos como se fossem provenientes de fora $e$ tomadas, por esta razão, como reais ${ }^{27}$. (Freud, 2007 p. 36)

Para se ter uma ideia mais completa desse aparelho linguageiro, retomaremos aqui o velho esquema psicológico da representação de palavra (1891), de Freud, do qual James Strachey, editor inglês da obra de Freud, reedita um trecho como "anexo C, Palavra e Objeto" no texto "O Inconsciente" (2006) 28 . Ao retomar essa antiga elaboração conceitual do Freud "neurólogo", Strachey reafirma a importância tanto do esquema como da concepção de representação aí presente, mostrando que esta continuará firme nas reflexões posteriores do pai da Psicanálise. Lacan, em boa parte de

${ }^{27}$ O Eu e o Id (1923). Volume 3

28 Este anexo está no artigo "O inconsciente", escrito em 1915; já o trecho acrescentado por Strachey é de 1891, quando Freud se ocupava dos distúrbios de fala, contestando os localistas Brocca e Werner, que hoje dão nome às áreas da linguagem no cérebro. Freud, 2006, Volume II. 
sua obra, também não deixou de enfatizar a importância desses textos iniciais de Freud, incluindo o renegado Projeto para uma psicologia científica. O que se nota, nesses trabalhos de Freud, como muito bem reforçam Garcia-Roza (2004) e Rego (2006), é um psiquismo-linguagem. Vejamos o esquema da "representação de palavra" como um exemplo que também pode nos inspirar um caminho nas considerações sobre oralidade e escrita.

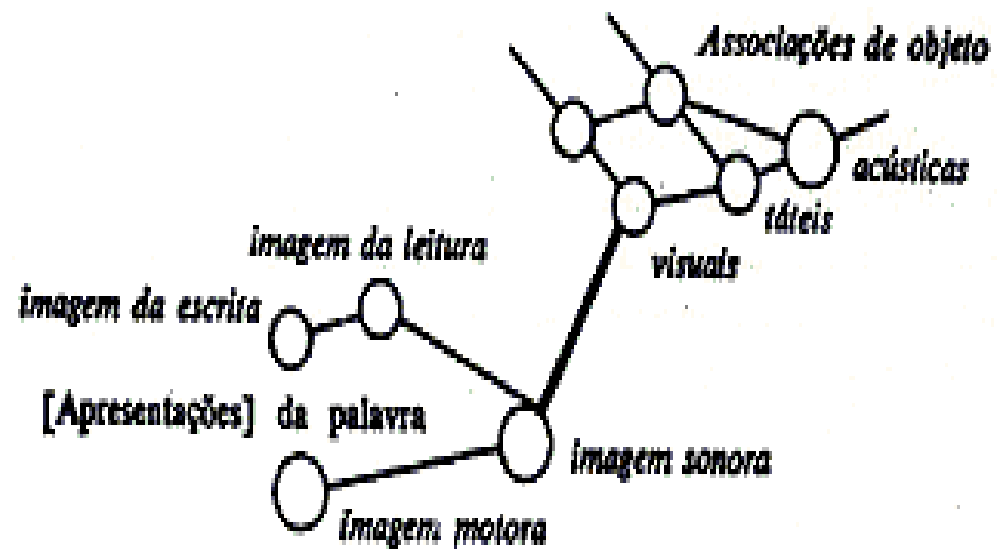

(Freud, 1977, p. 71)

Freud, ao discutir o esquema, insiste na centralidade da imagem sonora, que enfeixa as relações com o complexo da associação de objeto: A representação de palavra não se vincula à representação de objeto através de todos os seus componentes, mas somente a partir da imagem sonora (Freud, 1977, p. 59). O complexo "fechado" (por oposição ao "de objeto", que é "aberto") que forma a representação de palavra inclui as possibilidades da escrita e da leitura. Esse ato de considerar a escrita e a leitura (recepção e produção) como áreas localizáveis, ou como elementos de uma cadeia ou rede das possibilidades da linguagem, era próprio do paradigma neurológico e psicológico do século XIX, pois havia sempre a possibilidade de uma afasia, em que o paciente não conseguia falar espontaneamente, no entanto soletrava, lia ou escrevia, ainda que 
sem obter sentido. Dessa forma, boa parte dos esquemas de Brocca, Wernicke, Lichtheim, Grashey e outros (ibidem) traziam as ramificações para cada uma dessas habilidades de recepção e de expressão.

Freud, nos seis pontos que alinha nesse artigo para discutir o funcionamento normal ou patológico do aparelho, faz diversas referências às fases de aprendizagem, tanto da escrita como da fala. Os cinco primeiros tópicos iniciam com expressões do tipo: (1) Aprendemos a falar...; (2) Aprendemos a linguagem...; Aprendemos a soletrar...; (4) Aprendemos a ler...; (5) Aprendemos a escrever; (6). Se os neurólogos utilizavam as lesões e as autópsias, ou seja, o estado patológico de um sujeito como recursos para conhecer melhor o cérebro e sua topografia, Freud introduz também as disfunções presentes no funcionamento normal do aparelho, por exemplo, os esquecimentos, as trocas linguageiras, os gaguejamentos e outras parafasias motivadas pelo cansaço, pela distração ou então sob a influência de estados afetivos que o perturbam...(ibidem, p.35), o que acrescentava um empecilho nas conclusões inferidas a partir da localização das lesões. Como se pode considerar apenas a lesão como causa, se um indivíduo sem lesão também apresenta, em suas trocas linguageiras, parafasias momentâneas? Essa consideração levava Freud a pensar não em funcionamentos ou distúrbios localizados, mas sim em um articulado tecido cortical..., uma complexidade menos evidente. Ou seja, o pesquisador já traz nesse texto a ideia de um enredamento funcional.

Esse denso artigo apresenta uma versão do aparelho psíquico/de linguagem em que o conceito de representação é central e assume um modelo complexo, que vai além do associacionismo empirista da época e que até hoje surpreende pela sua atualidade. 0 psiquismo, ao reconhecer um estímulo exterior, não o faria por uma condução direta que vai da periferia do aparelho (regiões sensoriais) até um centro no córtex onde se imprimiu essa experiência anterior. 
Se, para os neurólogos da época, a condução do estímulo não representava um grande problema, já que esta era considerada neutra, ou seja, as fibras apenas conduziam sem afetarem ou modificarem o estímulo, para Freud, essa condução não seria simples ou mesmo direta, mas era parte de um sistema, sujeito a mudanças funcionais no percurso. No Projeto para uma psicologia científica ${ }^{29}$ (1988), Freud já utilizará o conceito de "diferença", ou seja, um estímulo não é igual a um outro que lhe antecede, haverá sempre uma diferença perceptível e é essa diferença que pode produzir um novo sentido. Isso já nos permite pensar que a escuta de uma palavra é sobretudo submissão à diferença e que a própria ideia de repetição - como processo fixador de uma forma - só pode ser aceita como fenômeno complexo, sujeito a efeitos de um sistema complexo. A contestação que Freud apresenta aos modelos de Brocca, Wernicke e de Lichtheim, que separavam os fenômenos da associação psíquica e o da representação - como se os processos ocorressem em centros distintos e interconectados por linhas neutras de condução - é o ponto de partida da ideia contemporânea de representação, presente depois nas concepções de Lacan, Derrida e outros. Vale a pena constatar algumas palavras desse incrível momento fundador:

Rejeitamos portanto as hipóteses de que o aparelho da linguagem consista em centros distintos, separados por regiões corticais isentas de funções e além disso que as representações (imagens mnésicas) que servem para a linguagem estejam acumuladas em determinadas áreas corticais denomináveis centros, ao passo que à sua associação procederiam exclusivamente as brancas massas fibrosas subcorticais. Só nos resta pois formular a hipótese de que a região cortical da linguagem seja um articulado tecido cortical dentro do qual associações e as transmissões em que se apoiam as funções da linguagem procederiam com uma complexidade não propriamente compreensível (1977, p. 62)

\footnotetext{
${ }^{29}$ Volume III (1895)
} 
Ao privilegiar a dimensão acústica do processo como elemento fundamental da representação, Freud praticamente gesta as raízes da "prevalência do significante" e, ao enfatizar a ligação entre representação de palavra e apresentação de objeto como um complexo, já elimina aqui a possibilidade de uma concepção naturalista de representação, em que o mundo externo figuraria como referente, como elemento que a palavra designaria diretamente, ou ainda a que prevalecia na época, que via a linguagem ou mesmo o psiquismo como epifenômenos do funcionamento neurológico. Para Freud, o fisiológico e o psíquico não constituem uma relação causal, com o primeiro sendo a causa do segundo: O psíquico é um processo paralelo ao fisiológico ( $a$ dependente concomitan) (1977 p.56). Reforça na sequência que o correspondente fisiológico da representação é da natureza de um processo em que sensação (estímulo fisiológico) e associação (enredamento das sensações) fazem parte de uma mesma dinâmica. Como acima mencionado, o aprender tem a sua relevância na constituição do aparelho, como diz Garcia-Rosa, comentando esse artigo de Freud: Diferentemente de um aparelho perceptivo, que nos colocaria frente a coisas a serem percebidas, o aparelho da linguagem nos coloca em presença de um outro aparelho de linguagem que nos introduz no registro da troca simbólica (2004, p. 40).

Para nós, esse aparelho interessa por incluir a leitura e a escrita como parte inerente do aparelho, ou seja, de qualquer modo é como se a escrita fosse uma decorrência da fala, ou seja, na impossibilidade de alcance do aparelho, lança-se mão de uma impressão não mais na ondulatória do ar, mas em alguma superfície sensível a marcas.

Na Interpretação dos Sonhos, Freud amplia as comparações do funcionamento do aparelho com a escrita: os restos diurnos, imagens ou sons de memória recente são reinvestidos durante o sono e 
reaproveitados como material de escrita - Lacan, em sua formulação do significante, apenas segue Freud, que interpretou o processo onírico como uma dinâmica de escrita, realçando a dinâmica do rébus:

O conteúdo do sonho, por outro lado, é expresso, por assim dizer, numa escrita pictográfica cujos caracteres têm de ser individualmente transpostos para a linguagem dos pensamentos do sonho. Se tentássemos ler esses caracteres segundo seu valor pictórico, e não de acordo com sua relação simbólica, seríamos claramente induzidos ao erro(...). O sonho é um quebra-cabeça pictográfico desse tipo, e nossos antecessores no campo da interpretação dos sonhos cometeram o erro de tratar o rébus como uma composição pictórica, e como tal, ela lhes pareceu absurda e sem valor. (1987. p 303) 30

Ainda oriundo da relação entre representação-de-palavra e representação-de-objetos, Freud faz uma comparação, nesta mesma obra, que nos abre um caminho curioso para as comparações entre psiquismo e escrita, Psicanálise e História da Escrita ${ }^{31}$. Trata-se de sua explicação das distorções de palavras no sonho:

As malformações verbais nos sonhos se assemelham muito às que são conhecidas na paranoia, mas que também estão presentes na histeria e nas obsessões. Os truques linguísticos feitos pelas crianças, que, às vezes, tratam realmente as palavras como se fossem objetos, e além disso inventam novas línguas e formas sintáticas artificiais, constituem a fonte comum dessas coisas tanto nos sonhos como nas psiconeuroses. (ib. id. p. 329)

No livro O Chiste e sua relação com o Inconsciente, Freud explicita melhor essas brincadeiras infantis, citando a linguagem

\footnotetext{
${ }^{30}$ Volume IV (1900). A Interpretação de Sonhos

${ }^{31}$ Gelb (1976 p. 44), que também estabelecia algo semelhante a esta comparação de Freud, recomendava que os decifradores prestassem atenção no modo como as crianças utilizam a palavra e o aproximassem do modo como os "povos primitivos" e os afásicos o fazem, ou seja, a palavra sendo tomada de modo muito concreto e até mesmo como objeto.
} 
secreta (criptológica) do Zittersprach, na qual as crianças acrescentam o som Zitter pra atrapalhar a pronúncia (veremos isso no próximo capítulo quando abordarmos as linguagens secretas). Ao longo dos anos, a criança vai deixando esses nonsenses e assumindo a linguagem dos adultos. Na adolescência, como mostra Freud, esse prazer de explorar o nonsense é retomado e, muitas vezes, exageradamente. Vejamos este trecho de Freud e o comparemos com um extraído da obra Cultura Popular na Idade Média e no Renascimento ${ }^{32}$, de Bakhtin, quando tematiza a parodização de temas e gêneros religiosos na Idade Média:

Igualmente, mais tarde, os estudantes universitários não prescindem destas demonstrações contra a compulsão da lógica e da realidade, cujo domínio, entretanto, percebem crescentemente mais intolerante e irrestrito (...) Com o eufórico nonsense de seu 'Bierschwefel', por exemplo, o estudante tenta recuperar seu prazer na liberdade de pensar, da qual vai sendo mais e mais privado pela aprendizagem da instrução acadêmica. (p. 123) ${ }^{33}$

Mais adiante comenta outra patuscada que ocorre entre congressistas, o Kneipzeitung, que distorce em nonsense as novas descobertas como compensação oferecida ao novo acréscimo em sua inibição intelectual (p. 123).

Vejamos agora o excerto de Bakhtin reinterpretando a questão para os jovens da Idade Média:

As recreações escolares e universitárias tiveram uma importância muito grande na história da paródia medieval. (...) Durante as recreações, os jovens repousavam do sistema das concepções oficiais, da sabedoria e do regulamento escolares e, além disso, faziam deles alvo dos seus jogos e das suas brincadeiras jocosas e degradantes. Eles liberavam-se,

\footnotetext{
32 A comparação não é meramente ilustrativa, pois essa obra de Bakhtin guarda estreita relações com várias hipóteses de Freud, sobretudo as que norteiam $\mathrm{O}$ Chiste e sua Relação com o Inconsciente: a inversão do alto para o baixo e vice-versa nos jogos de palavras, no chiste e no cômico; a descarga psíquica prazerosa e ao mesmo tempo desveladora das situações de poder e de domínio do outro.

${ }^{33}$ O Chiste e Sua Relação com o Inconsciente - Volume VIII (1905),
} 
antes de mais nada, dos pesados entraves da piedade, da seriedade ("da incessante fermentação da piedade e do temor divino".) e também do jugo das categorias lúgubres: "o eterno", "o imutável", "o absoluto". Opunham a elas o aspecto cômico alegre e livre, do mundo inacabado. (1999. p.72).

$\mathrm{Na}$ obra de Freud encontramos muitos outros exemplos que estabelecem essas relações entre a liberação das tensões do recalque a partir de algum folguedo linguístico ou mesmo da retomada de uma narrativa folclórica ${ }^{34}$.

Outro elemento interessante nessas aproximações entre psiquismo e escrita é o nome próprio. Lacan tenta extrair o efeito intrínseco de escrita presente no nome próprio, já que de uma língua para outra os traços principais da estrutura do nome se mantêm ou seja, o nome não se traduz, pois sua tradução perderia a essência de sua nomeação, no dizer de Lacan, o traço unário, o elemento mínimo que o permitiria identificar um único objeto. A ideia de traço, de marca, evoca sempre um objeto perdido, não uma positividade, uma presença, mas antes uma ausência. Mais que o traço, é o traço apagado, que apesar de não estar mais lá, ainda continua evocando uma presença ${ }^{35}$. No luto, por exemplo, pode-se notar a luta contra o esquecimento, seja na manutenção do nome ou de qualquer objeto que evoque a pessoa perdida. Entre os povos ágrafos, o nome, muitas vezes, será assimilado a um totem, a um fenômeno da natureza, como forma de lidar com a, como diz Derrida, "a desaparição da desaparição". Entre os Egípcios, por exemplo, crime pior que o parricídio seria apagar o nome do pai (crime hediondo praticado por Amenófis IV, que matou o pai e mandou martelar seus nomes dos monumentos).

\footnotetext{
34 Juntamente com Oppenhein, Freud chegou a esboçar a organização de um artigo intitulado "O Sonho e o Folclore". Volume XII (pp. 197-220).

35 Para Derrida (1995) é preciso radicalizar esse conceito de traço de Freud: $O$ traço é a desaparição de si, da sua própria presença, é constituído pela ameaça ou a angústia de sua desaparição irremediável, da desaparição da sua desaparição (p. 226).
} 
No campo da decifração, levando em conta as decifrações de Champollion, o nome do faraó Ransés (um nome verdadeiramente egípcio, talvez, RAMESES) permitiu ao francês superar as tentativas do inglês Thomas Young, que até então se esbarrava no entrave de que os nomes decifráveis eram de origem grega (Ptolomeu, Cleópatra e Alexandre). A suposição do pesquisador inglês era correta, os nomes dos faraós eram circundados por um cartucho (ou cártula) e suas escritas eram fonéticas e não semasiográficas (com valor de imagem), como se acreditava até meados do século XVIII; no entanto, como não conseguia avançar na decifração de nomes verdadeiramente egípcios (a língua não era conhecida), Young abandonou o desafio. Champollion sustentou e levou adiante a concepção de Young, mas foi buscar recursos no estudo do copta antiga língua egípcia preservada na liturgia da igreja Copta Cristã (Singh, 2001 p. 237). Sua primeira suposição baseou-se no princípio do rébus, já que o primeiro hieróglifo da cártula de Ransés era o desenho do disco solar:

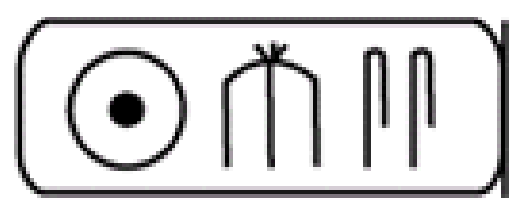

Cártula de Ransés, iniciada pelo disco solar

A inferência do francês, segundo Singh (ib id, p. 238), foi a seguinte: os novos relevos que estava estudando não poderiam conter nomes gregos (como era o caso dos nomes encontradas na pedra de Rosetta), pois eram muito antigos. Ao concentrar-se sobre essa estranha cártula e supor que a língua de base fosse o copta, experimentou o som "ra" para o primeiro elemento (o disco solar). Reutilizando os dois ideogramas do nome de Alexandre, supostos por Young em suas tentativas de decifração, o francês conseguiu chegar a R_SS (levando em conta que os escribas não usavam vogais, 
aproximou o som para RAMESES). Pela primeira vez na história da decifração dos hieróglifos, ocorria a decifração de um nome próprio egípcio. Com isso consolidou-se uma linha de decifração, que além de dar conta da escrita egípcia, constitui-se como paradigma para as demais decifrações (cuneiformes, linear b e outras).

o uso do nome próprio e o conhecimento (ainda que rudimentar de sua pronúncia mesmo que em outras línguas) também estarão presentes nas decifrações dos cuneiformes da Mesopotâmia e da escrita Linear B, da ilha de Creta. O alemão G. F. Grotefend recorreu aos nomes de Dario e Xerxes (império Persa), mas usando as formas do grego, hebraico e avéstico, conseguiu isolar as letras da estrutura de cada nome. O mesmo ocorreu na decifração da escrita linear B (da ilha de Creta) em cujas inscrições Michael Ventris procurou os nomes das localidades de Amnisos e Cnossos, já que também esses eram considerados nomes cujas estruturas consonantais seriam invariáveis. O interessante é que os nomes de lugares e de imperadores, citados por historiadores gregos, funcionaram como elementos de traços esvaziados de sentido pela ação do tempo e pelas sobreposições de línguas e culturas. Os decifradores, de posse de elementos sem sentidos, procuravam sempre o nome próprio como ponto de partida. A criança, em geral, faz a mesma operação ao entrar em contato com a língua - embora, nem todas o façam, existe perfeitamente a possibilidade de a criança tratar o nome do pai como um objeto indecifrável.

As reflexões de Lacan, partindo do inconsciente linguageiro de Freud, abrem um caminho promissor nessas correlações entre escrita e inconsciente, no entanto, sua intenção de correlacionar o automatismo de repetição ou mesmo o traço da coisa perdida (das Ding freudiana) a um certo modo de inscrição e repetição significante, ou ainda comparar as principais características da escrita à ideia de inscrição psíquica (conservar rastros, traços e usar outros suportes para expressão; funcionamento como rébus no sonho ou no 
sintoma) para ajustar a sua teoria de que o inconsciente funciona como linguagem, por vezes, reduz o complexo fenômeno da relação oralidade-escrita a alguns de seus traços, como por exemplo, o próprio conceito de letra que, em sua obra, é muito difícil de ser isolado - como mostra Rego (2006), desde A Instância da Letra no Inconsciente até seus últimos seminários, passando pelo Seminário 9 (Da Identificação), Lacan vai além do uso metafórico da escrita, passa a conceber alguns fenômenos do universo da escrita como um modelo do funcionamento psíquico, ou seja, encontra uma "escrita psíquica":

Certamente, a etapa da metáfora já revelava o isomorfismo entre o funcionamento do inconsciente e a escrita, percepção esta que possibilitou a importação dos significantes escriturais. Na segunda etapa, a escrita deixa de ser a escrita visível, fonética ou ideogramática, e passa à escrita psíquica, fundamento de todas as formações do inconsciente e das produções culturais (p. 245)

A formulação de uma teoria a partir do uso da metáfora como recurso epistêmico corre sempre o risco da redução excessiva das fontes, das metáforas originárias. Tanto Lacan como Derrida (1973, 1995) tentam retirar a escrita da dependência da fala, procuram concebê-la como uma linguagem autônoma, com traços de funcionamento que permitem estudos que vão além da ideia triunfante da secundaridade representativa, ou seja, de que a escrita seria apenas um desdobramento secundário da língua, espécie de subproduto da fala. Essa valorização do fenômeno da escrita em si, que permite considerá-la não um efeito da fala, mas um fenômeno intrínseco da linguagem humana, cuja existência, como suspeitava Lacan, já se põe como potência emergente pari passu com a emergência da fala. Os exemplos que apresentamos no capítulo 1 podem aqui ser re-evocados: a menina de dois anos, Luiza, que ao escutar a bronca da mãe: filha, você vai quebrar a tigela, isola o 
fragmento quebrar a tigela e o aproxima de um fragmento ouvido antes, ...quebrou a tigela e, nessa associação, traz o nome de uma letra de música, mãe, canta o Pato, que põe em jogo simultaneamente elementos de fala/oralidade e de escrita. A associação inconsciente entre as duas formas aciona "algo perdido" de uma cena anterior, então o jubiloso pedido dessa criança vem no sentido de recuperar o instante de prazer perdido. Vemos aqui que a fala serviu como suporte de uma outra inscrição e, nesse jogo - que guarda semelhanças com o fenômeno do rébus - uma forma se esvazia de seu sentido imediato e contextual (ou seja, da fala em ação) para receber um outro sentido e com isso desguiar totalmente a fala em seu percurso de sentido (em sua dinâmica de representação). Podemos dizer que os fenômenos essenciais de uma escrita latente estão aí presentes: um objeto (ou cena) perdido(a) que fez sua marca e se associou a uma outra marca menos visível (marca inconsciente, desejo de retorno ao aconchego materno) se inscreve, por efeito metafórico e metonímico, sobre a fala e sua cena discursiva. Há algo silencioso operando por detrás dos fonemas que faz com que ocorra a homofonia e o efeito de rébus (esvaziamento do sentido do primeiro fragmento para que o segundo se inscreva). Trata-se de uma nomeação singular: entre a primeira tigela (da música do Pato), e a dita pela mãe em outro contexto, corre uma subjetividade movida pelo desejo de recuperar o instante de prazer esvanecido.

De algum modo, temos efeitos da mesma ordem dos que ocorrem na escrita: para ler uma simples frase, como "O macaco comeu a banana", o sujeito passará por vários efeitos de alienação e separação:

1. Deverá se desprender da forma das letras, ou seja, se a identificação de cada forma ainda tiver relevo (devemos lembrar que a forma das letras varia: letra cursiva, bastão, letra de imprensa e 
outras; além de variar também de acordo com a grafia de cada pessoa). Aliás, Saussure (1969), ao discutir a questão do valor linguístico, mostra que o mesmo fenômeno ocorre com a escrita. Os fenômenos da "diferenciação", como elemento básico da discriminação dos elementos significantes e significados, ocorrem tanto na fala (audição) como na escrita (visão). Na fala, para isolar uma unidade e associá-la a um sentido é preciso que o contínuo dos fonemas e dos sentidos seja matriciado por um sistema diferencial: "bata", só se distingue de "pata", por um traço diferencial: o fonema /b/ é sonoro (vozeado), enquanto /p/ é surdo ( não vozeado). Na escrita ocorre o mesmo, vejamos o exemplo dado por Saussure ( $p$. 138):

Como se comprova existir idêntico estado de coisas nesse outro sistema de signos que é a escrita, nós o tomaremos como termo de comparação para esclarecer toda a questão. De fato:

10. os signos da escrita são arbitrários; nenhuma relação existe entre a letra t e o som que ela designa;

20. o valor das letras é puramente negativo e diferencial; assim, a mesma pessoa pode escrever $t$ com variantes tais como:

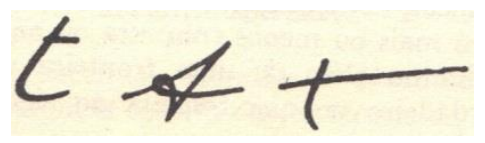

A única coisa essencial é que este signo não se confunda em sua escrita, com o do l e do d etc.(pp. $138,139)$

Saussure prossegue com mais dois itens, no terceiro reforça a ideia de oposição recíproca entre os signos e, no quarto, insiste na ideia de que o meio de produção é totalmente indiferente - Quer eu escreva as letras em branco ou preto, em baixo ou alto relevo, com uma pena ou com um cinzel, isso não tem importância para a significação (p.139)

Então, a subjetividade de nosso pequeno (ou grande) tem que se haver com um traço, que permita fixar o limite de cada letra independentemente de sua materialidade e de sua estilização. 
Constatamos sempre, em nossas pesquisas com crianças que não conseguiram se alfabetizar nos anos iniciais do Fundamental, que nem sempre isso é tão fácil. Michael ${ }^{36}$, por exemplo, implicava com o $\mathrm{P}$ que eu cacografava na lousa para escrever a primeira letra do nome de seu pai (Paulo): "esse não é o $\mathrm{P}$ do meu pai, o do meu pai é assim ó..." e desenhava um $\mathrm{P}$ mais caprichado, fugindo de minha estilização ${ }^{37}$.

Sabemos que a afirmação de Saussure de que o meio é indiferente para o sentido é questionável, pois desde que existe escrita há muitos usos (como o da publicidade ou mesmo da poesia concreta) que fazem as letras tomarem o caminho da motivação sígnica: o S da marca Sadia, por exemplo, sugere a textura e o movimento de salsicha ou linguiça; luzes trocando de cores e de formas num letreiro reforçam a ideia de alegria, de festa, de ambiente animado.

2. O sujeito tem que se separar da pregnância (alienação) que as relações da escrita-fala (ou vice-versa) podem suscitar - isto desde a relação grafema-fonema aos níveis maiores (palavra, frase), ou seja, sair do efeito da leitura subvocalizada, conferida, que não consegue abstrair o sentido. O dedo, por exemplo, apontando para cada fragmento de palavra ou mesmo para a palavra é uma cena típica de leitura conferida, de fixação na correlação grafema-fonema (alienação). A boa leitura exige fluência, ou seja, desprendimento das correlações ("descontextualização"), mas ao mesmo tempo exige também certa prontidão para diferenciar efeitos de sentido que exploram justamente essas correlações. Trata-se da dialética da alienação e da separação, ou seja, é necessário passar pela letra,

\footnotetext{
${ }^{36}$ O caso completo está relatado e analisado em LIMA (2006), tese de doutorado sob minha orientação.

37 Pommier, acompanhando as comparações de Freud e Lacan entre escrita e psiquismo, retoma essa exigência de apagamento da forma das letras como um necessário recalque: "L'ecriture et la lecture réclament une mise em acte du refoulement, sans lequelle celui qui voit les signes restera attaché à leur forme et n'arrivera pas, par consequént, à degager ume valeur litterale subsistant seulement dans leur effacement" (p. 203).
} 
pelo som, mas numa dinâmica de desprendimento e de captação do essencial, do traço metonímico de cada elemento e de suas formas maiores, como na leitura esperta de um poema, como este de José Paulo Pais, em que a palavra violino é uma palavra valise, que contém também duas possibilidades de frase: vi o lino; ouvi o lino:

\author{
Havia um pernilongo \\ chamado Lino \\ que tocava violino. \\ Mas era tão pequenino \\ o Lino \\ e tocava tão fino \\ o seu violino \\ que nunca ouvi o Lino \\ nem vi o Lino \\ (Paes, 2006, p. 17)
}

Esse é mais um ponto fundamental no processo da alfabetização e do letramento que iremos discutir com mais detalhes nos capítulos II e III. Mas, desde já, é possível perceber que aqui se rompe com o impasse entre leitura ideográfica (global) e leitura fônica, que suscita a chamada "guerra dos métodos"38.

3. Ao conseguir reunir os cinco signos (o macaco comeu a banana) e obter o seu sentido mais imediato (a cena), ainda resta ao leitor a operação mais sofisticada da leitura: o efeito de retroação, ou seja, a possibilidade de uma leitura em que a correlação entre significantes e significados irá oscilar em função do contexto, do gênero, do discurso. Por exemplo, essa frase poderia significar "o ingênuo acaba de cair na armadilha" - pois, sobre essa primeira camada de sentido, uma outra se inscreve (à revelia dos signos) e, mesmo sem um querer objetivo. Em outras palavras, despeja-se sobre essa leitura algo de um não sabido, vindo de outra cena da vida (uma letra apagada), que pode, por exemplo, investir nessa frase o gozo de uma

\footnotetext{
${ }^{38}$ Em Belintane (2006a) procuramos diluir essa dicotomia e ir além dessa antiga polêmica.
} 
vingança ${ }^{39}$. Da reflexão sobre o funcionamento da letra e do nome podemos extrair o que poderíamos chamar de essência primária da leitura, que nada mais é do que a possibilidade da retroação e do esvaziamento de signos, fazendo valer a camada significante.

A Linguística, a Análise do Discurso, a Psicanálise de Freud e Lacan e as reflexões pós-estruturalistas, como as de Derrida, abrem perspectivas interessantes no campo do ensino. As duas mais importantes consistem nessas possibilidades de se conceber a escrita como uma imanência da linguagem e como um fenômeno que pode ser pensado de forma autônoma - com isso é possível sair da pregnância que a correlação fala-escrita ordena e abrir perspectivas para análises mais minuciosa do processo de entrada da criança na escrita. Mesmo a comparação de Saussure entre fala e escrita permite ir além de uma secundaridade representativa, já que os fenômenos que prevalecem tanto em um sistema como no outro podem ser pensados como uma linguagem. Ou seja, perceber pela visão ou pela audição (ou por ambas) as diferenças entre elementos, abstrair o som ou a letra de tal maneira que vários de seus elementos sejam apagados; exercer a retroação para perceber o sentido ou ainda para esvaziar o sentido primeiro e inscrever um segundo, tudo isso, constitui um conjunto de habilidades de linguagem comuns aos dois sistemas, o que nos permite afirmar certa imanência da escrita, como considerada no esquema de Freud e em sua comparação da linguagem do sonho com uma escrita pictográfica.

\footnotetext{
${ }^{39}$ A questão da retroação levou Lacan (1998c) a formular e a reformular uma figura topológica que ele designou de Grafo do Desejo. Essa construção amplia as possibilidades de reflexão sobre a leitura, mostrando em seus desdobramentos e patamares os elementos essenciais da constituição da subjetividade linguageira: fala, significante, desejo, eu, Outro pontuam e desdobram os sentidos de uma frase ou de um texto desde o nível direto da linearidade dos significados da palavra em sua sintaxe às dimensões enunciativas em que o esvaziamento dos significantes é recoberto por outros sentidos, tal qual se pode ver na leitura que fizemos do poema de José Paulo Paes.
} 
Por outro lado, como estamos no campo do ensino de língua e não na clínica psicanalítica e nem na gramatologia derridiana, temos que observar o efeito da redução teórica ocorrida na extração dessas importantes iniciativas teóricas. Em Belintane (2008) procuramos mostrar que alguns psicanalistas, entre eles Pommier (1993), ao retomar essas reflexões sobre escrita e psiquismo, em suas rearticulações teóricas, acabam não levando em conta que essas reduções ${ }^{40}$ precisam ser revisitadas ou relativizadas. No caso, em seu Naissance et renaissance de l écriture, Pommier, seguindo uma pista freudiana, retoma com muita propriedade a história da escrita e tenta provar que a origem do alfabeto está ligada ao surgimento do monoteísmo, inicialmente no Egito com Akhenaton e, após, entre os povos semíticos com o êxodo dos hebreus do Egito liderados por Moisés. Na tentativa de aproximar a filogênese da escrita de sua ontogênese, o psicanalista francês insiste na idéia de parear as articulações do complexo de Édipo (p.245) com as articulações possíveis dos elementos estruturais da escrita (imagem, desenho, letra, consoantes e vogais). Associa o modo de fazer prevalecer o desenho ou a imagem (fase dos pictogramas e ideogramas) ao gozo mítico do corpo (o gozo do Outro, Jouissance de l'Autre), momento hipotético em que a criança experimentaria a angústia diante do perigo de ser tragada pelo gozo do Outro - lembrando os três tempos da castração de Lacan (1999), seria o tempo da identificação imaginária com o objeto de desejo da mãe. A imagem remeteria portanto ao paraíso perdido, à estabilização, ao domínio completo do imaginário, como diz Pommier (p. 244)

\footnotetext{
${ }^{40}$ Reduções no sentido de que, ao se apropriar de um episódio ou de um elemento, por exemplo, do rébus ou das fases de cada escrita, nem sempre se levam em conta elementos mais complexos trazidos pelos historiadores. Dito de outro modo: se podemos pensar a escrita de forma autônoma, como um sistema, com seus efeitos que não dependam exclusivamente da fala, não se podem dispensar os efeitos da fala, sobretudo da oralidade, sobre as escritas e as escrituras. Nesse sentido, uma retomada mais detalhada de alguns pontos da história da escrita e da leitura é mais do que pertinente, pois não dá para dizer que esta forma ou este suporte se transformou neste ou naquele elemento, sem vincular aí os feitos e efeitos, por exemplo, da corp-oralidade humana (voz, uso das mãos etc.).
} 
À articulação da escrita em que a imagem é lida como rébus, o pesquisador francês associa o recalque primordial, recalque do gozo do Outro ("refoulement primordial"). Já à fase em que as escritas se tornaram consonantais (como o grego antigo) associa o "recalque secundário" e, por fim, à fase em que os gregos inserem os símbolos para as vogais, associa o "retorno do recalcado":

\begin{tabular}{|l|l|l|l|}
\hline $\begin{array}{l}\text { Joussinace } \\
\text { De IÁutre }\end{array}$ & $\begin{array}{l}\text { Refoulement } \\
\text { Primordial }\end{array}$ & $\begin{array}{l}\text { Refoulement } \\
\text { Secondaire }\end{array}$ & $\begin{array}{l}\text { Retour } \\
\text { du refoulè }\end{array}$ \\
\hline $\begin{array}{l}\text { Pictogramme } \\
\text { Ideogramme }\end{array}$ & $\begin{array}{l}\text { Hieroglyphe } \\
\text { Ideophonogramme } \\
\text { Rébus } \\
\text { Syllabisme }\end{array}$ & $\begin{array}{l}\text { Consonantisme } \\
\text { Ecriture de la loi }\end{array}$ & $\begin{array}{l}\text { Vocalisme } \\
\text { Alphabet }\end{array}$ \\
\hline
\end{tabular}

O autor utiliza esse quadro para interpretar as fases (ou estruturas) de aprendizagem da escrita na ontogênese, baseando-se, para isso, entre outras, nas pesquisas de Evelin Levy, que possivelmente tenha feito seu trabalho na trilha de Ferreiro e Teberosky (1989), pesquisadoras que colocam toda a ênfase na progressão por fases: garatuja, desenho e fases da escrita (présilábica, silábica, silábico-alfabética e alfabética).

Ao trazer para nossa pesquisa os enfoques que redescobriram na história da escrita o embate entre oralidade e escrita (Parry, Lord, Havelock, Ong, Olson, Saenger, Chartier, Svenbro, Cavallo, Denny) ${ }^{41}$, podemos acrescentar uma dúvida ao quadro de Pommier (1993, p.245), já que em seus esquemas, ao privilegiar a passagem da imagem e do pictograma para a escrita fonética, deixa de fora a oralidade ritualística e, ao fazer isso, exclui a possibilidade de o recalque se pôr entre o que imobiliza o corpo e fixa os olhos (a leitura silenciosa) e o que põe verdadeiramente o corpo em gozo, a catarse por meio da voz, a escrita que se faz com o corpo, aquela que se produz a partir do contato direto com os deuses ou com o real do

\footnotetext{
${ }^{41}$ As referências serão feitas mais adiante.
} 
corpo, a escrita da inspiração. Revisitando estes autores, também pretendemos lançar mão de algumas descobertas que a aproximação desses dois campos nos proporcionou.

A passagem das formas pictográficas para formas menos dependentes do contexto, mais propensas a funcionar como suporte da língua, deu-se, em geral, sob forte influência dos textos da tradição oral de poetas, sábios e religiosos. Havelock (1996a, 1996b) conclui que a oralidade grega não só resistiu às possibilidades de ser totalmente subjugada pelo alfabeto, como também paradoxalmente o modificou, criando o algoritmo silábico ${ }^{42}$ que hoje conhecemos (consoante-vogal) a partir da influência da métrica, do ritmo e dos recursos de sua vigorosa tradição oral. Então, a visibilidade das vogais entre as consoantes seria apenas uma metonímia de um universo realmente perdido: o mundo dos bardos, menestréis e sacerdotes das culturas orais - ou seja, se os símbolos para as vogais foram criados para que a escrita se adaptasse melhor à leitura em voz alta do texto poético, o acréscimo desse recurso dispensou de vez o corpo do bardo como portador de texto e emprestou um uso amplo à voz sem corpo:

A musa que cantava traduz-se num escritor: ela, que requeria pessoas para ouvirem, convida-as agora a ler. Faz-se justiça ao atribuir-Ihe ambos os papéis. Não foi o alfabeto inventado sob a sua égide, quando o seu canto ainda era supremo? Devemos negar-lhe o crédito pela sua invenção e pela sua capacidade para o usar? (p.79)

\footnotetext{
42 Havelock (1996c), contrariamente ao que normalmente se divulga, afirma que os gregos não acrescentaram símbolos para vogais a um alfabeto consonantal trazido pelos Fenícios, mas sim formularam pela primeira vez uma representação visual de um ruído linguístico à nossa espécie, que era simultaneamente econômica e exaustiva: uma tabela de elementos atômicos que, através de seu agrupamento numa inesgotável variedade de combinações, consegue, com razoável precisão, representar qualquer ruído linguístico existente ( $p .78)$, ou seja, em vez de apenas reutilizar símbolos para vogais, o que houve foi a verdadeira invenção da consoante, pois, nos silabários consonantais da Mesopotâmia, o que estava em jogo era um símbolo para uma sílaba.
} 
Svenbro (1988) afirma que o termo "kleos", "fama" é um dos elos entre a oralidade e a escrita nascente. A fama que era a glorificação do herói se dava por este termo, "kleos", cujo sentido demarca a sonoridade, o ato de cantar ou de se fazer ouvir:

\begin{abstract}
A glória de um Aquiles é, portanto, uma glória para o ouvido, uma glória sonora, acústica. No plural 'kleos' é de fato o termo técnico que Homero utiliza para designar sua própria poesia épica. Em sua sonoridade, a palavra é eficaz, é ela que faz existir o herói.
\end{abstract}

Nesse contexto de passagem da Grécia oral para a da escrita, Svenbro introduz uma pergunta instigante e fornece uma resposta que explica como e por que a escrita ganhou prestígio:

Para que serviria a 'escrita muda' em uma cultura na qual a tradição oral se acredita capaz de assegurar sua própria permanência sem outro suporte além da memória e da voz dos homens? A resposta mais simples parece ser a seguinte: justamente para a produção de mais 'kleos', por exemplo, graças às inscrições funerárias, que garantiram uma nova forma de posteridade ao morto. (pp. 41,42)

A escrita passa, então, a refletir o 'kleos' da cultura oral e isso justifica a predominância da leitura em voz alta na Grécia. Analisando o vocabulário grego para o fenômeno da leitura, ou mais precisamente para os cinco vocábulos que expressavam o verbo ler, "némein" - que significa "distribuir" -, apesar de ser pouco usual, o autor atesta alguns usos, por autores da época, desse verbo no sentido de "ler em voz alta", ou seja: compartilhar uma informação lida por alguém nas tabuinhas (por exemplo, conferir uma lista de guerreiros ou de pretendentes) ou ainda recitar algo (uma lei, uma genealogia) que se tem na memória.

Outro dado interessante da leitura na Grécia é que o ato de ler era considerado passivo. A leitura, em geral, era feita em voz alta por uma pessoa que podia se submeter, por exemplo, um escravo. Leick 
(2003) mostra que também na Mesopotâmia a escrita se deu a partir da transcrição de textos orais, por exemplo, na formação de escribas prevalecia a cópia de listas de provérbios, classificadas a partir de temas, tais como "pobreza", "casamento", "cidade" etc. Na tentativa de registrar fielmente os textos, em geral sagrados, ou socialmente muito valorizados em razão de seu poder civilizatório, o escriba produzia ajustes na fonetização, transformando a escrita burocrática em uma escrita literária profundamente enraizada na tradição oral. Discutindo as "instruções de Churupaque", Leick mostra os conselhos de um pai (Churupaque) a seu filho, uma longa e copiosa lista (sessenta linhas) de instruções, provérbios e exortações sempre introduzidas pelo refrão "Churupaque deu instruções a seu filho" ( $p$. 92). Aqui o texto escrito tenta ser fiel à própria cena oral em que o conselho teria acontecido e procura-se preservar o tom e a postura em que o sábio, o rei ou mesmo o senhor dono da casa manifesta a sua sabedoria e estende o seu poder. Vejamos a seguinte observação de Leick:

...com a modificação da escrita de uma forma de registro burocrático para um sistema baseado na fala torna-se mais difícil adquirir instrução. Entretanto, no que dizia respeito aos escribas, suas possibilidades de exercer maior influência aumentaram, sobretudo quando penetraram nas estruturas administrativas de templos e outros grandes domínios onde eram indispensáveis não só para cuidar da administração, mas também pela capacidade de se dedicarem à disseminação de propostas ideológicas para influenciar a opinião pública" (2003, pp. 94, 95)

Havelock (1996) fornece abundantes exemplos de sobrevivência das fórmulas orais nos textos escritos na Grécia no período em que o alfabeto começa a se disseminar. Do capítulo 9, "Os gregos antes da escrita", de "A revolução da escrita na Grécia", extraímos uma de suas conclusões: 
O alfabeto grego, tanto na época em que foi inventado, como muitas gerações depois, não foi usado, em primeira instância, para transcrever enunciados coloquiais, mas sim para transcrever o que antes se tinha composto segundo as regras de memorização. É por isso que a literatura grega, até a morte de Eurípides, é predominantente poética. Essa literatura, portanto, escapará à nossa compreensão enquanto efetuarmos a nossa crítica exclusivamente de acordo com as regras da composição letrada. Essas regras, quaisquer que sejam, pode-se dizer que se introduziram lenta e gradualmente em uma condição de tensão crescente entre as modalidades oral e escrita da linguagem. (1996, p. 190)

Pommier (1993) toma como base o recalque e o retorno do recalcado nas passagens da escrita pictográfica para a escrita alfabética (com vogais), mas parece desconhecer ou elidir outros elementos importantes da consolidação do alfabeto na Grécia e no Ocidente. Por exemplo, quando associa o retorno da vogal no alfabeto (é preciso lembrar que, para essa visão psicanalítica a vogal é sempre da ordem do gozo), qualifica o fenômeno como o "retorno do recalcado", ou seja, o esquelético alfabeto fenício, cujo silabário reduziu-se em um sistema consonantal, com os Gregos recebeu novamente o sopro vocálico. Claro, não dá para ter dúvida, as vogais de fato foram suprimidas (reprimidas?!), mas as grandes reprimidas mesmo foram a voz e a pantomima do rapsodo, que ele exercia sob a inspiração das filhas de Mnemosine, as musas. Quando as epopeias retornam nas produções europeias humanistas e renascentistas, sobrou apenas uma matriz textual que servirá para os poetas da escrita simularem o que foi oral, o que era escrito na base da inspiração, da invocação das musas. As musas do Tejo de Camões não passam de uma ficção assumida, pois seu poema não é canto, é escrita, produzida na solidão e não mais diante de uma plateia que tinha fé nas musas e nos heróis.

Retomando uma reflexão de Vico e outras de autores que enfrentaram a questão homérica, Rancière estende a questão para o 
jogo moëbiano entre consciente (pensamento que pensa) e inconsciente (pensamento que não pensa), puxando na esteira de Homero, a figura emblemática do Édipo:

A figura do Édipo, como tema trágico exemplar e universalmente válido, tem como antecedente essa figura hermenêutica do "verdadeiro Homero". Ela pressupõe um regime de pensamento em arte em que o próprio da arte é ser a identidade de um procedimento consciente e de uma produção inconsciente, de uma ação voluntária e de um processo involuntário, em suma a identidade de um "logos" e de um "pathos".( 2009 p. 30)

Nesse sentido, a própria epopeia de Camões vai além de uma produção técnica ou de um mero engajamento estético, pois em sua produção vincam-se a faixa do logos - seu domínio da técnica - e a do pathos, seu contributo singular, oriundo talvez de seus tormentosos delírios de homem do mar em momento de façanha única.

O retorno das vogais ao alfabeto paulatinamente representou 0 silenciamento do rapsodo, mas, por outro lado, abriu o caminho para uma estética em que uma nova corporalidade se projetou, mas agora sem o símile diante dos olhos. Em outras palavras, os novos efebos e seus sucedâneos tiverem que aprender a extrair os músculos, os cabelos longos e loiros, a armadura e o gládio em punho do herói Aquiles, não mais da pantomima do rapsodo, mas de um emaranhado de traços inscritos na superfície de um pergaminho enrolado (volumen). As mãos, em vez de brandir o gládio e o escudo junto com o herói, estarão ocupadas em desenrolar e a enrolar o volumen. Como mostra Havelock (1996c $)^{43}$, muitos efebos e rapsodos

${ }^{43}$ Todas as considerações razoáveis apontam, não para uma pronta aceitação do alfabeto, mas para uma resistência (...). A oralidade primária só lentamente saiu da Grécia, numa taxa a ser determinada pelo grau a que a linguagem escrita armazenada substitui a linguagem oral armazenada. Traços de 'leis' (mais corretamente 'regras', isto é, 'thesmoi' inscritas sobrevivem em Creta talvez até finais do século VII). O primeiro texto coerente (numa parede) é datável de 450 a. C. A chamada Constituição de Quios talvez tenha sido inscrita cem anos antes. 
resistiram, não suportaram essa gigantesca perda, essa exigência de imobilidade do corpo. Entretanto, com o tempo, outras gerações foram assimilando a perda, e compensando-a com a agilidade de "um corpo" apenas imaginado, um software já não tão dependente dos periféricos (rosto, braços, mãos e outras partes do corpo que se implicavam na pantomima da recitação), mas um corpo que também podia (e ainda pode) produzir calafrios, fazer suar e até pôr-se junto com o herói em guerras e amores pelo mundo afora, sem que se tire as nádegas da poltrona. Embora, frisemos, para se obter esse privilégio - até hoje - é necessário que se domine completamente não só o sisteminha enjoado dos rabiscos no papel, mas também o jogo de distanciamento e aproximação entre a pregnância da letra enquanto corpo físico diante dos olhos e os instantâneos que a sua fluência vai liberando ao longo da experiência.

Até aqui, apenas tentamos mostrar que reconhecemos a força pulsional e desejante que faz sua letra (Freud e Lacan) e que abre vertentes para uma escrita fonetizada, mas como enfiamos nesse meio as nossas reflexões às tensões sobre oralidade/escrita, tentando buscar um "recalcado" mais extenso e amplo que o retorno das vogais defendido por Pommier (a corporalidade do rapsodo), tentaremos, no restante deste capítulo, pontuar essas tensões com o auxílio de autores que as tematizaram, mas que não têm compromissos com a concepção de psiquismo e linguagem da psicanálise. Após essa digressão, retornaremos nos capítulos seguintes com os dados de nossa pesquisa, produzida a partir dessa esquiza concepção de escrita-oralidade, que tem um pé nessa trajetória do inconsciente estruturado como linguagem e o outro na história da escrita e das tensões desta com a oralidade.

Estes registros epigráficos, juntamente com o 'código legal' ateniense, tal como foi revisto no final do século $V$, ainda retêm, como já foi notado, traços de formulações requeridas quando tais regras eram uma questão de memorização oral (p. 106). 
Em nosso tempo, quando uma criança domina (ou se deixa dominar por) os elementos de uma narrativa a partir da escrita, quando consegue conjuminar seus elementos e sua progressão usando os olhos-ouvidos como recepção, temos aí uma projeção interessante de uma corporalidade que tem seu tributo lá na iniciação do efebo. Havelock (p. 86) afirma que até os cinco ou sete anos a criança é oralista, mesmo estando diante de adultos profundamente marcados pela escrita. Para a nossa reflexão, é importante essa relação entre a entrada das comunidades orais na escrita (sobretudo a dos Gregos, que é a mais estudada) e o modo como a criança conjuga suas histórias e textos ouvidos com os que irá ler depois.

Vejamos um mágico momento na literatura de nosso tempo, em que o narrador de Infância (Ramos, 1972) põe-nos diante da dura iniciação de uma criança moderna, que com nove anos ainda tem dificuldades para enfrentar sozinho a aspereza das letras: após leituras mal sucedidas de um pequeno romance diante do pai e com uma síntese na memória que este faz do trecho já lido, o menino tenta continuar sozinho, mas hesita, procura ajuda para acompanhar o restante da narrativa.

\footnotetext{
Alinhavei o resto do capítulo, diligenciando penetrar no sentido da prosa confusa, aventurando-me às vezes inquirir. E uma luzinha quase imperceptível surgia longe, apagava-se, ressurgia, vacilante, nas trevas de meu espírito.

Recolhi-me preocupado: os fugitivos, os lobos e o lenhador agitaram-me o sono. Dormi com eles, acordei com eles. As horas voaram. Alheio à escola, aos brinquedos de minhas irmãs, à tagarelice dos moleques, vivi com essas criaturas de sonho, incompletas e misteriosas. (p. 215)
}

Nesse estado de euforia, a criança volta, nos dias seguintes, a procurar o pai para continuar a história, mas este responde com uma 
"falta": afastou-me com um gesto carrancudo (p. 216). Diante dessa negativa, procura a prima, que inusitadamente traz-Ihe uma alegoria para incentivá-lo a ler sozinho:

falou-me dos astrônomos, indivíduos que liam no céu, percebiam tudo quanto há no céu. (...) Ora, se eles enxergavam coisas tão distantes, por que não conseguiria eu adivinhar a página aberta diante de meus olhos? Não distinguia as letras? Não sabia reunilas e formar palavras? (p. 217)

Com essas duas faltas e a bela alegoria dos astrônomos, o menino vai para o quintal buscar sua solidão de leitor iniciante. Nesse momento, Graciliano nos brinda com umas das mais belas reflexões sobre o nascimento de uma vocação:

E tomei coragem, fui esconder-me no quintal, com os lobos, o homem, a mulher, os pequenos, a tempestade na floresta, a cabana do lenhador. Reli as folhas já percorridas. $E$ as partes que se esclareciam derramavam escassa luz sobre os pontos obscuros. Personagens diminutas cresciam, vagarosamente me penetravam a inteligência espessa. Vagarosamente.

Os astrônomos eram formidáveis. Eu, pobre de mim, não desvendaria os segredos do céu. Preso à terra, sensibilizar-me-ia com histórias tristes, em que há homens perseguidos, mulheres e crianças abandonadas, escuridão e animais ferozes. (pp. 214, 215).

O percurso que essa criança faz diante das "faltas" que the foram impingidas é da oralidade para a escrita, pois, no capítulo anterior, o protagonista mostrava como ouvia as narrações bíblicas feitas por Padre Pimentel. Interessante, para nossa tese, observar o encontro de sua memória cotidiana com os novos elementos oriundos do imaginário bíblico proposto pelo padre (como o fizeram no verso as crianças citadas no capítulo anterior, ou o próprio narrador de "Infância", no episódio do "sapo boi", que usamos no capítulo I): 
Não hesitei, ouvindo as mudanças de homens e gado, com certeza tangidos pela seca, em situar a Caldeia no interior de Pernambuco. E Canaã, a terra de leite e mel, aproximava-se dos engenhos de cana-de-açúcar. Mantive essa localização arbitrária, útil à verossimilhança do enredo, espalhei seixos, mandacarus e xiquexiques no deserto sírio, e isto não desapareceu inteiramente quando os mapas vieram. (p. 210 ${ }^{44}$

O elemento mais essencial da leitura já está, portanto, nesse jogo entre oralidade e fala cotidiana; no entanto, o encontro entre essa memória oral e as que estão no escrito figuram para nós como uma estratégia crucial para compreender os esforços das crianças diante do alfabeto. O rapsodo e a musa de Havelock incorporados na escrita, ou o narrador desaparecido de Benjamin(1986) ${ }^{45}$, retornam, ainda que não mais com o vigor de antes, mas na dimensão de um recalcado, que vem persistir como elemento deflagrador da "escassa luz" que se derrama sobre os escritos. A morte do rapsodo e o envolvimento das culturas orais com as grafocêntricas têm seus desvãos por onde se pode infiltrar o narrador recalcado, sobretudo quando o educador se põe nessas brechas e retoma esse jogo das vertentes entre das duas antigas tradições. Certeau(1996) ${ }^{46}$ enfatiza essa sobrevivência e abrangência de uma cultura oral subjacente à escrita e às tecnologias contemporâneas (telefone, rádio, televisão) e realça a importância da tradição oral na ampliação da capacidade de ler da criança (p. 336) - ponto de vista muito similar ao nosso.

\footnotetext{
${ }^{44}$ Notem como Paulo Freire (1982) já estava dentro de Graciliano. "Infância", se bem lido, pode simplesmente recobrir e enriquecer autores e conceitos da educação contemporânea.

45 Benjamin(1986), em O Narrador: Considerações sobre a obra de Nikolai Leskov, mostra que o romance, tal qual o conhecemos, rompe com uma tradição de narradores que tem sua origem no narrador épico, mas mostra o conto de fadas ou as narrativas como as de Leskov (que se baseiam em contos de fadas) como uma espécie de continuidade do ato de contar história.

${ }^{46}$ Esta parte da obra, "Uma ciência prática do singular", Certeau conta com a parceria de Luce Giard
} 
Ong (1998) assume dois modos de oralidade: a primária, que corresponderia à das sociedades ágrafas, em cujo meio prevaleciam o texto formular, a narrativa, o verso baseado em estéticas de memorização (a métrica, o ritmo, a repetição e alegorias - sempre exigindo integralmente a corporalidade presencial; e a secundária, que seria

(...) a nossa oralidade, ou seja, esta da alta tecnologia, na qual uma oralidade é alimentada pelo telefone, pelo rádio, pela televisão ou por outros dispositivos eletrônicos, cuja existência e funcionamento dependem da escrita e da impressão. (p. 19).

As reflexões de Havelock, Ong, Olson e outros estudiosos das exclusões e interpenetrações que se dão entre cultura oral e cultura escrita, por vezes, tomam o rumo de uma certa dicotomia - como a acima mencionada. Em geral, consideram os dois blocos de uma forma homogênea, sem levar em conta que, tanto dentro de uma cultura oral como dentro da escrita há diferenças e heterogeneidades nos modos de distribuição e apropriação de uma e outra47. Uma cultura oral tem seus "autores" - como mostram Parry e Lord (Lord, 1997), e uma dessas marcas de autoria pode ser vista na atuação dos bardos dos Balcãs ${ }^{48}$ (Lord, ib. id.) e nas performances de nossos repentistas nordestinos, que só são bem considerados quando conseguem improvisar diante das situações inusitadas de cada apresentação. No caso dos repentistas, para que sejam reconhecidos como tais, o postulante deve dominar os mais diversos estilos e possibilidades da versificação, conforme Vicente Reinaldo, repentista

\footnotetext{
${ }^{47}$ Essa heterogeneidade ocorre tanto nas sociedades orais contaminadas ou não pela escrita como nas que têm a escrita como dominante na organização geral da política, do trabalho e de amplos setores da vida social, mas que todavia mantêm vastos setores, sobretudo das classes desfavorecidas, vivendo 'de direito' sob o domínio da escrita, mas resolvendo 'de fato' boa parte de seus problemas cotidianos a partir de uma visão de mundo profundamente enraizada na fala prosaica e em elementos da oralidade tradicional.

${ }^{48} \mathrm{Um}$ deles, poeta Iugoslavo a quem Lord (1997) atribui o epíteto de Homero moderno, Avdo Mededovic, que apesar de ser alfabetizado e de expandir suas temáticas por meio da leitura, mantinha seu estro nas fórmulas básicas da composição oral. Esse fenômeno ocorre também com poetas da tradição oral nordestina, como Zé da Luz, Patativa do Assaré e tantos outros.
} 
nordestino, em uma de suas apresentações aos meus alunos oriundos da FFLCH, em meu curso "Metodologia de Ensino de Língua Portuguesa, em 2005, comprovou. Vale a pena abrir aqui um parêntese sobre esse importante encontro: Reinaldo, ao retomar um mote proposto por um aluno de letras, diante do desafio de que o repentista deveria provar que seus versos eram de fato criados na performance, começou (com seu colega, Orlando Dias) a cantar fora de ritmo, com dificuldades na busca das rimas, até que, de repente, interromperam. Vicente, debochando, brincou: "Paramos porque tá feio, o verso tá com o pé quebrado. Vocês sabem por que tá assim? Porque o mote não tem ritmo, não tem pé. Podemos mexer no mote sem mudar o assunto?". Após remendos no mote fornecido, a cantoria prosseguiu dentro da métrica e do ritmo.

O episódio demonstrou que, mesmo para fornecer um simples mote a cantadores, não pode ser qualquer um da platéia. É preciso que o propositor do mote enquadre o tema dentro de uma métrica e deixe uma boa rima pra cantoria render. (Vicente argumenta que se for deixada uma rima rara, do tipo sangue, os cantadores serão obrigados a mudar o estilo para mudar a rima.)

Os amadores da cantoria em geral são meros imitadores ou ainda simples consumidores - que gostam, amam o que ouvem, alguns até memorizam suas cantorias preferidas ${ }^{49}$, mas ficam siderados na catarse da obra, sem forças para dominar a sua maquinaria simbólica. São poucos os que conseguem ouvir e adotar uma postura subjetiva que os leve à autoria, à capacidade de recitar com entonação própria ou mesmo de compor. Já os autores, mesmo quando não têm acesso à poesia (letra) através dos olhos, como os cegos cantadores (Sinfrônio e Aderaldo são notáveis exemplos), e os

\footnotetext{
${ }^{49}$ Um "memorizador de cantoria" nem sempre é um cantador. São importantes porque salvam a cantoria do esquecimento, permitindo que cantadores amadores coloquem em circulação o que estaria destinado ao esquecimento. Foi graças a memorizadores desse tipo que Leonardo Motta conseguiu organizar o seu Cantadores (1987)
} 
analfabetos (como Anselmo Vieira de Sousa), assimilam o estro pelo ouvido (Motta, 1987).

Na escrita, também temos leitores que nunca ultrapassam a camada parafrástica de um texto ${ }^{50}$, são leitores que só conseguem lançar mão da inferência fraca e são suscetíveis às alegorias - basta ver, por exemplo, a legião de fãs de autores como Gabriel Chalita ${ }^{51}$, Paulo Coelho52, Rubem Alves ${ }^{53}$, Içami Tiba54 e outros, que se valem fartamente de alegorias bem tradicionais para se fixarem como gurus de boa parte dos professores - como se fazia nas comunidades orais.

Seja na escrita ou no oral, podemos distinguir com facilidade um modo de recepção mais propenso à autoria, ao envolvimento reflexivo de um modo mais alienante e catártico ${ }^{55}$. O mesmo esquema pode ser levado à sociedade tecnológica: há, por exemplo, do ponto de vista da alienação, muitas semelhanças entre os aficionados pelas novelas de televisão e os consumidores de jogos ou de outras diversões baratas na Internet, que chegam a preocupar educadores face à propensão ao vício a que seus usuários estão sujeitos.

\footnotetext{
${ }^{50}$ No capítulo seguinte pretendemos discutir a adivinha, texto de origem oral, como um modelo para se compreender alguns fenômenos que perpassam a oralidade e a escrita, e, para isso, vamos recorrer a quatro posições subjetivas na recepção de um texto (seja oral ou escrito): fragmentária, parafrástica, crítica, extrapolativa. Nesse sentido, esse termo que usei, "camada parafrástica" se tornará mais claro e mais contextualizado.

51 Ex-secretário da educação do Estado de São Paulo, autor de muitos livros na linha da auto-ajuda, muitos tendo a educação como contexto. Quando secretário, tinha a pretensão de liderar os professores da rede estadual por meio de discursos "alegóricos". Após sua saída da secretaria, tornou-se um dos campeões de voto nas eleições para os legislativos estadual e federal.

52 Escritor de renome internacional na mesma linha da autoajuda alegórica.

53 Apresenta-se como teólogo e psicanalista e seus livros fazem muito sucesso entre os professores brasileiro;

54 Psiquiatra, suas palestras e livros fazem muito sucesso; nelas os educadores encontram conselhos triviais, mas quase sempre marchetados por alegorias bem simplórias. Seu sucesso o levou à televisão, onde sempre aparece como especialista em questões ligadas à indisciplina e às relações entre pais, alunos e família.

55 Mais uma vez aqui poderíamos aproximar o processo do par alienação e separação. O amador fica mais preso à alienação, já os com propensão a autoria envolvem-se na dialética da alienação e da separação.
} 
A partir desses dois polos propostos por Ong para compreender a oralidade, podemos projetar a possibilidade de uma terceira dimensão e, ao mesmo tempo, pensando na faixa de Moëbius, de uma unidimensão: a terceira seria a oralidade periférica, ou seja, uma forma de sobrevivência "esfarrapada" da oralidade tradicional, que podemos ver, por exemplo, nas favelas, nas quais pessoas oriundas de lugares de forte tradição oral (por exemplo, o Nordeste com seus cantadores, emboladores, rezadeiras, cordelistas e outros mestres da oralidade), convivem oprimidos pela cultura da escrita, mas, ao mesmo tempo, sem ligação com a sua tradição. O fenômeno também se dá nas classes favorecidas, sobretudo quando a escrita pragmática do trabalho e as formas de lazer se restringem às mídias, menosprezando as escritas mais densas (seja a literária ou a das ciências humanas). O que parece prevalecer é uma apropriação muito parcial dos poderes da escrita - não é por acaso que Foucambert (1994 p. 33), no final da década de oitenta, encontrou números tão estarrecedores quando quis saber o nível de leitura do francês: ...uma minoria (entre $15 \%$ e $20 \%$ ) consome sozinha $85 \%$ da produção escrita, enquanto o restante da população francesa tem com a escrita apenas encontros ocasionais. (p.33). Já no Brasil, uma pesquisa de 2007, executada pelo Instituto Pró-livro e Ibope, afirma que $55 \%$ dos brasileiros são leitores ${ }^{56}$.

Pesquisando em uma favela da Zona Oeste de São Paulo, nossa equipe constatou que, para introduzir um texto da tradição oral nordestina (cordel, repente, embolada), é preciso um bom

\footnotetext{
56 Possivelmente a metodologia utilizada (perguntar se a pessoa leu um livro nos últimos três meses) favoreça o número de leitores, pois a pesquisa, apesar de levantar dados sobre dificuldades de leitura, só leva em conta os $16 \%$ de analfabetos dentro da amostra de não-leitores. Um dos itens da pesquisa (sempre a partir de declaração direta) revela que $42 \%$ dos entrevistados teriam problemas de leitura (Lentidão: 17\%; problema de compreensão: 7\%; falta de paciência: $11 \%$; falta de concentração: $7 \%$ ).

http://www.prolivro.org.br/ipl/publier4.0/dados/anexos/48.pdf (consulta em julho de 2011).
} 
preâmbulo, pois boa parte dos alunos costuma rejeitar esses gêneros como se fossem produtos de pouco prestígio. No entanto, aceitam com facilidade os que vêm da televisão ordinária (programa do Faustão, do Gugu Liberato, do Ratinho e de outros, ou as novelas, "Big Brother" e filmes de narrativas simplórias e heroicas). Aliás, a televisão reaproveita ao seu modo essa herança oral, produzindo programas que exploram narrativas amorosas formulares (novelas), humor, situações picarescas, esportes, que antes eram temas da voz e do ouvido.

Ainda dentro da ideia de que com a morte do rapsodo perde-se uma corporalidade mimética, caberiam estudos mais detalhados que talvez pudessem reinterpretar os fenômenos da música contemporânea (os mega-shows dos roqueiros, por exemplo) voltada para as classes alta e média como um certo "retorno" ("do recalcado") do antigo show mimético dos rapsodos (o tom agonístico, guerreiro, é comum nesses shows). O rap, com sua gesticulação em que o índex parece a todo momento cobrar um aqui e agora de uma bravata ou de um clamor de vingança, retoma parte dessa corporalidade: é interessante ver na favela como as crianças chegam a dispensar a letra da música, para se agarrarem na gesticulação, na ginga de seus "rappers" preferidos, soerguendo o orgulho em tom de desafio, mesmo sem compreender integralmente o que se diz na letra (por incrível que possa parecer, nem sempre há proximidade entre a letra dos rappers e as comunidades periféricas, estes já trazem termos e construções que vão além da cultura linguística localizada).

Já a unidimensão, certa passagem tranquila de um lado da faixa para o outro, ocorre quando uma criança oriunda de uma família letrada consegue manejar a escrita reaproveitando as habilidades narrativas e linguageiras que viera cultivando desde o berço, ou ainda, uma criança de um meio menos letrado, mas de rica herança oral, que estabelece passagens da fala cotidiana para os textos mais formalizados que guarda na memória - por exemplo, Graciliano ouvia 
as narrativas bíblicas, mas recontextualizava as imagens a partir do seu mundo conhecido. Esse jogo de contextualização e recontextualização (que chamamos de posição subjetiva, aproximação e afastamento, alienação e separação) pode dar-nos uma perspectiva privilegiada para enxergar com mais clareza a relação oral-escrita, mas mantendo uma perspectiva menos homogênea.

Do mesmo modo que a oralidade primária grega, por exemplo, deve ter se bifurcado, criando um ramo resistente que tenderia a morrer em sua dureza e um outro que sobreviveria ou até mesmo se aproveitaria da escrita para expandir suas próprias habilidades oralistas - Platão, ao aproveitar o discurso oral de Sócrates em seus escritos, pode ser um representante desse ramo emergente - na escrita tais bifurcações também devem ter feito sua heterogeneidade, pois, em uma sociedade complexa e dividida como a nossa, é natural que a escrita funcione também como um divisor de águas, criando resistências ou mesmo distribuições e influências limitadas, e que, entre um modo ou outro de apropriação, apareçam exploradores que tirem proveito econômico da situação: há mercados que sabem dialogar eficientemente com pessoas que não se dão bem com a escrita, sejam elas das classes sem ou com privilégios (os gurus, exemplos dados nas páginas anteriores, constituem uma boa fatia deste mercado).

Em geral, o fenômeno da descontextualização é um elemento crucial para os defensores da tese que atribui à escrita uma posição chave no surgimento do pensamento racional e científico do mundo ocidental Macluhan (2006); Havelock (1995); Goody (1986); Goody e Watt (2006); Olson (1997) e outros. O pensamento, ao ser manejado pela escrita, tem mais condições de se descontextualizar, de sair do imediato e partir para formas mais abstratas de representação. Distanciar-se do falado e de suas circunstâncias permite a interpretação, nesse sentido, a escrita já promove por si 
esse distanciamento e ainda, por ser fixa, permite a releitura, a retomada que fornece a interpretação. Olson (1995), um dos defensores dessa tese, analisa autores que mostram as mudanças ocorridas com o surgimento do protestantismo, que vai promover a leitura autônoma, mais descontextualizada, ou seja, sem a interpretação já pronta da igreja católica. Em paralelo ao protestantismo, surge a ciência que também vai promovendo a leitura do mundo e encontrando uma linguagem para expressar os fenômenos e refletir sobre eles.

Mesmo acompanhando as reflexões que tentam mostrar que as culturas orais são capazes de elaborar boa parte das habilidades exigidas pela escrita, ou ainda que a escrita se apropriou justamente do que havia de melhor na cultura oral, essa discussão, feita sob a ótica da generalização, sem levar em conta as marcas e situações de heterogeneidade que indivíduos, famílias e grupos estabelecem tanto ao assumir os recursos da oralidade como os da tecnologia em geral (entre eles, a escrita). Vimos, por exemplo, que, mesmo quando os historiadores tentam apontar um marco para o surgimento da leitura silenciosa, não podem ignorar muitos documentos que apontam leitores que liam em silêncio desde o mundo grego (Saenger 1998). Resumindo: as formas de apropriação foram diferenciadas desde o início, seja do oral ou do escrito.

Do mesmo modo, podemos conceber nossas salas de aula e até mesmo o mercado de trabalho ou ainda os leitores de hoje a partir de uma visão que leva em conta a heterogeneidade das situações. Se podemos dizer que a assimilação das formas abstratas da geometria e do algoritmo da multiplicação ou a compreensão de um artigo de opinião da imprensa significam avanços de uma mentalidade que a escrita propiciou, isso não nos permite enxergar que esses sucessos ocorreram ou ocorrem de uma forma homogênea. Há, sem sombras de dúvidas, pessoas com muitos anos de escolarização que são incapazes de pensar de forma descontextualizada tanto as figuras 
geométricas como as quatro operações. (Isso dá para perceber quando se introduz, por exemplo, o conjunto dos números inteiros nesse novo contexto, a simples operação entre números negativos e positivos parece constituir um ponto de enrosco no avanço da aprendizagem da matemática e de sua linguagem). Ou ainda os que usam a leitura e a escrita de forma muito direta, sem compreender (ou mesmo se interessar por) as dimensões polissêmicas e interdiscursivas de um texto.

Tfouni (2008) mostra que o fenômeno da dispersão pode se dar tanto na produção oral como na escrita, e que nem sempre o grau de escolaridade é suficiente para indicar maior ou menor propensão à autoria.

Considerando o outro lado, o da cultura oral, não é difícil deduzir que, dentro de público ouvinte de cantorias, haverá sempre alguns que conseguem ir além da pregnância imaginária, ou seja, que são capazes de escutar de forma descontextualizada, ouvindo não apenas o cantor mas a maquinaria verbal e seu modo de funcionar ou seja, uma escuta mais pendente para o simbólico do para o imaginário. ${ }^{57}$

Se até aqui utilizamos a figura do rapsodo de uma forma um tanto alegórica, convém situar um pouco melhor o seu desaparecimento e a emergência do leitor de corpo silencioso. Segundo Havelock (1996), a entrada do alfabeto na Grécia por meio dos Fenícios não pode ter se dado antes do século VII a. C. E a sua divulgação e uso intelectual se deu paulatinamente - esse estudioso toma a morte de Tucídides como marco para situar a poesia homérica. Desde setecentos, ou seja, por mais de trezentos anos, as

\footnotetext{
57 Os conceitos aqui são baseados em Lacan, mas omitimos de propósito a dimensão do real, pois queremos apenas mostrar que a escuta de uma cantoria pode ficar presa à história, ao ritmo, aos efeitos mais aparentes - como, por exemplo, a catarse no teatro. Ou então, despertar uma escuta que vai além dessa pregnante camada e envolva os modos de composição do texto, ou seja, sua maquinaria simbólica. Nesse sentido, o imaginário estaria mais para a alienação e o simbólico mais para a separação. No entanto, temos que admitir a dialética entre alienação e separação só se dá com os incômodos e nonsenses do real.
} 
letras se esbarravam na forte cultura oral grega. Seu interessantíssimo Prefácio a Platão (1996) tenta matizar essa zona confusa, que vai dos tempos homéricos a Platão, e entender as duas investidas paradoxais de Sócrates, a do Fedro (em que Sócrates questiona a leitura como recurso para se obter sabedoria) e a da República, em que investe contra os poetas, tomando Homero como o maior de seus representantes.

Já na República, Platão (2001) dispara contra os poetas homéricos, tentando estabelecer diferenças entre esse modo catártico, mimético e alegórico (simulacros) e a maiêutica dialética da filosofia socrática. O duplo paradoxo é que Platão transmitirá a filosofia socrática e a sua por meio da escrita, mas mantendo o diálogo de estilo socrático (aí, já em seu nascimento, temos um exemplo de escrita estruturada a partir de uma textualização oral). E Sócrates, um dos maiores mestres orais da história, entrará para a eternidade sob a escrita de Platão e de outros seguidores. A voz de Sócrates e seus gestos e rituais se perderam, apenas um ou outro ainda podem ser percebidos nos textos, por exemplo, o momento, no Banquete, antes da entrada na casa de Agaton, em que o filósofo se distancia de Aristodemo para meditar sozinho.

Nesse tempo do "Banquete", embora já fosse possível ler com um alfabeto completo, ainda restavam duas dificuldades complexas: resolver o problema do suporte (pois os rolos tinham suas limitações) e ampliar o público leitor para que as obras pudessem chegar mais longe.

Svenbro, Cavallo e Saenger ${ }^{58}$ atestam práticas de leitura silenciosa entre os gregos, mas estas eram raras, o comum era a audição do texto. A permanência da chamada scripta continua vinda dos gregos até o século XII atesta que a leitura silenciosa (scipiere) só foi se instalando bem tardiamente à medida que a edição dos

\footnotetext{
${ }^{58}$ Seus artigos estão reunidos na coletânea História da Leitura no Mundo Ocidental, organizada por Cavallo e Chartier, 1998.
} 
textos foi também se transformando. A passagem do rolo (volumen) ao livro encadernado (codex) que se consolidou no início do século $X$ (Cavallo, 1998 p. 91), associada a mudanças editoriais (espaço intervocabular, marcação de parágrafos, divisão da obra em partes, índices e outros recursos) facilitou ainda mais a leitura silenciosa e analítica. Vários historiadores retiram da empolgação de Santo Agostinho, quando comenta o modo como Santo Ambrósio lia, um exemplo evidente de que a leitura silenciosa ainda (século IV) causava estranhamentos:

Mas, quando lia, os olhos divagavam pelas páginas e o coração penetrava-Ihes o sentido enquanto a voz e a língua descansavam. Nas muitas vezes em que me achei presente (...) sempre o via ler em silêncio e nunca de outro modo. (Agostinho, 1984 p.91)

A sedução que o livro poderia exercer também era outra preocupação, sobretudo dos líderes religiosos, que preferiam os livros sagrados, ou mesmo os de filosofia e ciência, sempre nas mãos de um mestre, que além de ler, limitava os sentidos (modos de leitura da igreja) à doxa predefinida pela tradição da igreja. A ruptura proposta por Lutero e Calvino tem como um de seus pontos a liberdade de interpretação dos livros sagrados, tanto que até hoje a imagem do protestante é sempre marcada pela bíblia segura na axila. A leitura silenciosa significou parte dessa liberdade, pois ao ler para si mesmo, em silêncio, o leitor saía da inspeção direta de seus superiores ou mesmo da doxologia que ditava a entonação de acordo com a interpretação atribuída ao trecho.

Alguns autores contemporâneos como Smith (1989), Foucambert (1994), Goodman (1997) apostam na autonomia dos olhos durante a leitura e atribuem à leitura lenta certa dependência da fala, como se o leitor não fosse capaz de extrair os sentidos diretamente, sem uma passagem pela pauta sonora, fato esse que 
atrasaria o fluxo e limitaria a apreensão dos sentidos. Ou seja, para eles a leitura silenciosa não apenas se consolidou, mas também se tornou o modo significativo e verdadeiramente intelectual de ler; desse modo, para esses autores, desde sua iniciação nas letras o leitor já deveria ir relegando o ouvido a um segundo plano.

De fato, é grande o número de leitores que mesmo após quatro ou cinco anos de escolarização continuam lendo com excessiva dependência da identificação dos fonemas e das sílabas. São leitores que experimentam dificuldades na compreensão de textos simples, que são incapazes de se valer de inferências mais profundas.

Enfrentar as letras em silêncio, posicionado como sujeito capaz de usar bem esse esvaziamento de som, é um fenômeno que na história da escrita fez um percurso longo e difícil. As dificuldades de nossas crianças e dos muitos não-leitores localizados por Foucambert talvez nos coloquem diante de, no mínimo, dois modos de aprendizagem que marcam os leitores, cujos polos talvez representem posições discursivas que os acionaram.

Finalizando este capítulo, reiteramos o que vimos em nossa abordagem da história da escrita e da leitura: o alfabeto só gestou a leitura silenciosa a partir de uma intensa ampliação de seu uso, sobretudo a partir do momento em que os leitores puderam escapar das leituras autorizadas e ritualísticas e também sair das constrições que mantinham o texto como dependente da vocalização (a scripta continua, a ausência de marcas que ajudassem o leitor situar palavras, frases, temas e partes do texto) - antes de acionar o entendimento, o texto era dito, declamado. Ou seja, pouco a pouco, essa voz, que já fora a voz dos rapsodos, passa a ser e ainda é o nó górdio da leitura.

As questões formuladas passam necessariamente por este silenciamento e seus efeitos. Em nossas pesquisas encontramos crianças que são capazes de dar voz a um texto muito rapidamente, mas sem compreender seu sentido. Também encontramos outras que 
extraem essa voz com muita dificuldade, subvocalizando cada palavra, cada sílaba, a tal pondo de o efeito de retroação que enlaça o sentido não se fazer. Mas também há - são poucas mais existem crianças que conseguem ler com fluência e em silêncio, compreendendo em profundidade o texto que leem.

Moraes (1996), um dos defensores da metodologia fônica em alfabetização, cita um episódio interessante para ilustrar sua concepção de leitura. Retoma o episódio da cegueira do poeta Milton, que era um excelente conhecedor de grego, e que após ter perdido a visão ensinou às suas filhas o alfabeto grego, de tal modo que elas pudessem fazer uma leitura em voz alta, mesmo não compreendendo o sentido. Com frequência reapresento esse episódio aos meus alunos com a mesma formulação: quem está lendo de fato? As respostas constituem quase uma unanimidade: Milton é quem lê, pois é ele quem faz a compreensão. De fato, o foco na compreensão e em uma dinâmica subjetiva que a realiza é o que prepondera nas teorias contemporâneas.

A partir do que vimos na história da escrita e nas formulações de Freud e Lacan, quanto à letra e à subjetividade, podemos, agora, afirmar a importância da compreensão moëbiana entre o som e a letra. Sabemos, através do rébus, que a operação de apagamento da imagem e a exploração de sua homofonia foram fundamentais para o aparecimento dos silabários e do alfabeto; e que a voz do rapsodo (e até mesmo a de Sócrates e de outros mestres do oral) também foram silenciadas enquanto performance, mas, nas práticas de leitura, o que se passou a ouvir foi a voz do leitor no púlpito, pois a voz manteve seu resto e, por isso, a leitura silenciosa demorou para emergir e, ainda hoje, é apenas um dos modos de ler, em geral, dos intelectuais.

Em resumo, podemos concluir que o par oralidade-escrita pode ampliar as concepções de escrita da psicanálise para além da ideia de um recalque incidindo sobre a imagem ou o som das vogais. 0 
elemento de fato recalcado é, para nós, o corpo. Há um corpo perdido em toda escrita, por outro lado, como há também a emergência de uma nova corporalidade (de um possível leitor silencioso, que consegue projetar-se um corpo imaginado durante a leitura da obra).

A partir dessa ideia de corpo perdido, nessa passagem da oralidade para a escrita, podemos reinvestir nossa concepção de sujeito intervalar, que se posiciona entre textos, entre meios, entre modalidades de linguagem. Podemos também entrever nesses posicionamentos subjetivos a questão da heterogeneidade, ou seja, assumir que tanto na oralidade como na escrita, haverá propensões a certos posicionamentos mais ligados ao imaginário, ou seja, o receptor assumindo os significados de uma forma mais direta e alienante, sem as mobilidades que the permitam interpretações mais descontextualizadas; ou então, posicionamentos mais simbólicos, mais propensos a despregar-se das primeiras camadas do texto para enxergar suas dimensões discursivas e polissêmicas - em outras palavras, a emergência de um sujeito na dialética da alienação e da separação.

O que se gesta aqui, para compreender melhor o leitor emergente, sobretudo nas séries iniciais, é uma abordagem dinâmica da oralidade-escrita, a partir de uma concepção de sujeito, esboçada nesses dois capítulos, que leva em conta o desejo e um conceito de psiquismo em que o inconsciente linguageiro pode ser concebido como estruturador das condições básicas que permitem a leitura fluente e significativa. Nossa concepção pretende superar essa antiga dicotomia em que olhos e ouvidos se dividem.

No próximo capítulo, tentaremos mostrar como a educação contemporânea na esfera pública vem mantendo a dicotomia oralidade-escrita e posicionando as crianças de acordo com um pernicioso pragmatismo, que em nada favorece à formação de bons leitores. Como contrapartida a essas críticas, apresentaremos 
também nossa concepção de oralidade e explicitaremos suas potencialidades linguageiras também no campo da leitura e da escrita. 


\section{CAPÍTULO II}

\section{DO LITERAL AO LITERÁRIO}

As duas diferenças mais marcantes entre nossa perspectiva de trabalho e as que preponderam hoje no discurso educacional brasileiro, a construtivista e a sociointeracionista, estão na concepção de sujeito e na possibilidade produtiva da relação inconscienteconsciente. Os construtivistas, por exemplo, partem sempre de uma escrita que se constrói por meio de uma subjetividade ativa, centralizada. Nossa concepção de trabalho parte das habilidades linguageiras ${ }^{59}$ da infância, tendo como referência o conceito de oralidade definido no capítulo I, que põe em relevo o corpo como suporte de "um modo de escrita" e uma subjetividade de permeio, intervalar. As diferenças de abordagem ficam bem claras quando consultamos algumas orientações que seguem para os professores das escolas públicas de hoje - vejamos, como exemplo, a definição do conceito de "sondagem" dada abaixo pelo Guia de Planejamento e Orientações Didáticas do Programa Ler e Escrever da rede estadual paulista (nosso grifos ressaltam o centramento na escrita):

É uma atividade de escrita que envolve, num primeiro momento, a produção espontânea pelos alunos de uma lista de palavras simples sem apoio de outras fontes de escrita. Ela pode ou não envolver a escrita de frases simples. É uma situação de escrita que deve, necessariamente, ser seguida da leitura pelo aluno daquilo que ele escreveu. Por meio da leitura, você poderá observar se o aluno estabelece ou não relações entre aquilo que ele escreveu e aquilo que ele lê em voz alta, ou seja, entre a fala e a escrita. (SÃO PAULO, 2008, p. 33)

\footnotetext{
59 Utilizamos a expressão "habilidade", mas não no mesmo sentido que atualmente se utiliza. Na nossa concepção, uma habilidade não se constitui isoladamente, só funciona em rede com outras, portanto qualquer item avaliável sempre se constituirá de uma rede de habilidades e nunca de um só ITEM como se apregoa, por exemplo, nas avaliações da Prova Brasil, do SARESP e de outras que utilizam as teorias de competência e habilidade associada à Teoria (estatística) de Resposta ao Item - TRI.
} 
Note-se que o aluno é confrontado com a escrita mesmo que ainda não tenha o seu domínio. O que se quer é extrair daí sua hipótese de escrita, ou seja, a hipótese da hipótese - a hipótese que vem do professor e da teoria, que acreditam que esse aluno, ao escrever uma palavra ditada pelo professor e ao lê-la depois, revelaria de forma transparente seu conhecimento sobre a escrita e, a partir daí, poderia ser concebido como um sujeito classificável em uma das fases ou níveis previstas pela teoria (pré-silábico, silábico, silábico-alfabético e alfabético $)^{60}$.

Já nossa concepção de diagnóstico procura na oralidade a dinâmica de uma escrita. O par é assimilado de forma moëbiana, ou seja, a oralidade tradicional (sobretudo a da infância) se enreda com a principal modalidade de escrita - a que mais nos interessa para alfabetizar e promover a entrada da criança no universo letrado: a literária. Os rituais da oralidade, como vimos no capítulo I, se diferenciam, mas também se imbricam com a fala cotidiana - o mesmo ocorre com a literatura, seja infantil ou adulta. Então, o diagnóstico da escrita incide primeiro nas habilidades linguageiras da oralidade e apontam para o misterioso simbólico da função poética presente sobretudo nos textos literários escritos da cultura oral.

O outro polo da diferença entre nossa concepção de ensino da oralidade, leitura e escrita, em relação à vigente (construtivismosociointeracionismo), pode ser desmembrado em quatro dicotomias:

- Utilidade $x$ Desutilidade

- Proximidade x Distância

- Comum x Estranho

- Letramento-escrita - oralidade-literatura

60 De Lemos (1998) opõe a esse desvelamento, a opacidade, ou seja, certa precaução para não enxergar a fala da criança de maneira direta, sem levar em conta o cruzamento de outras falas e demandas que a tensionam. 
Essa topologia bem marcada de um suposto sujeito bem posicionado, que paulatinamente domina o objeto linguagem ou, então, que se estrutura na dimensão de um outro externo, palpável e presentificável, leva os educadores a encontrar os campos e setores da vida em sociedade que supostamente favorecem a compreensão dos "usos" da linguagem, de sua "função social", ou ainda, os gêneros e textos escritos que estão disponíveis no cotidiano da criança, ao alcance de seus olhos e de sua cognição interessada (seu "universo de letramento"). Tudo isso parece brotar de uma transparência que reduz os mistérios da singularidade e do desejo da criança a uma instância planejável, articulável em uma pedagogia ao alcance da mão. No campo aplicado da alfabetização a situação é ainda mais complexa, pois quase sempre a teoria é reduzida a uma prática caricatural, como observa Smolka em sua pesquisa:

Contudo, ao invés de se tomar o estudo de Ferreiro \& Teberosky como contribuição para o entendimento dos processos de aquisição da escrita, tem-se reduzido o ensino da escrita à questão da correspondência gráficosonora, categorizando criança e turmas de crianças em termos de níveis de hipóteses(...). (2003 p.63)

O estado da arte que desanda nesse pragmatismo todo é muito bem intencionado, pois procura honestamente uma ruptura com a escolarização do texto, com as concepções tradicionais que punham a gramática normativa, a estrutura idealizada da língua, como ponto de partida e de chegada de todas as atividades do ensino de Língua Portuguesa.

Além dessa vertente construtivista, uma plêiade de bons autores que emergiram nas frondes do marxismo, Vigotski, Bakhtin, Bourdieu, Labov, Snyders, além de outros da área da análise do discurso, Pêcheux, Maingueneau, reforçaram e ainda reforçam a ideia de que língua e linguagem são instrumentos de poder e, na escola, estariam mais a serviço das classes dominantes do que das classes 
populares. Um conjunto de metáforas e alegorias econômicas e sociológicas deu corpo a alguns princípios interessantes e bem intencionados, expressos a partir de conceitos de origem marxista: condições de produção e de circulação, uso, reflexão, práxis, valor, ideologias, trabalho etc. Soares (1989), em seu Linguagem e Escola: Uma perspectiva social, obra que exerceu significativa influência na década de noventa, deixa bem claro a emergência desse fundo epistêmico:

O conhecimento recente, mas já significativo - das relações entre linguagem e classe social e 0 reconhecimento dos aspectos políticos e ideológicos dessas relações, numa sociedade de classes, apontam para um ensino da língua materna radicalmente diferente. ( p.78)

Na década de noventa, sob essas influências, estabelecida na forma de uma síntese meio aberta entre Análise do Discurso francesa e as importantes obras de Vigotski e de Bakhtin e, ainda, em alguns casos, acrescida da concepção construtivista de Ferreiro \& Teberosky, firmou-se uma concepção de alfabetização e de ensino de Língua Portuguesa que vem prevalecendo discursivamente nas redes de ensino e em praticamente todas as instâncias administrativas dos governos. Nos Parâmetros Curriculares de Língua Portuguesa (PCNLP) (BRASIL, 1998b), as ideias de uso-reflexão e de construção do conhecimento, associadas à concepção de gênero de Bakhtin foram assumidas nas instituições oficiais e no mercado de didáticos de uma forma bastante abrangente, não obstante, como mostraremos, de forma bem equivocada, chegando mesmo a contrariar os ideais de suas fontes e de seus divulgadores ${ }^{61}$.

${ }^{61}$ Talvez aqui se possa argumentar que a má assimilação dessas influências se deu
em função da expansão rápida do ensino, que implicou na contratação de
professores mal formados ou mesmo da implementação apressada do regime de
ciclos; no entanto, o que vamos analisar adiante mostra que o cruzamento entre
neoliberalismo e propostas marxistas (como também se deu na política econômica)
vai se dar nas obras e projetos de fomentação do ensino, boa parte deles a partir 
Esse sujeito transparente - com uma cognição que se constitui e se impulsiona na dimensão de um outro sociológico e econômico veio a se configurar como um sujeito de prontidão, aberto à intelecção dos gêneros úteis de seu cotidiano (de um sujeito da práxis chegou-se a um sujeito utilitarista, captador do que seria supostamente útil para a cidadania). Um suposto universo de letramento permitiria aos educadores dessa perspectiva imaginar um sujeito ativo entre textos do cotidiano, navegando entre receitas, instruções de uso, listas, cartas, bilhetes, embalagens, rótulos etc. (Nas páginas 111 e 112 dos PCN-LP o professor encontra uma lista de gêneros adequados à linguagem escrita.) Tudo isso surgiu nesse importante clima de embate, sustentando um novo polo na dicotomia da luta, cuja intenção seria a de acabar com a chamada "escolarização da leitura", tanto dos "pseudotextos das cartilhas" como dos textos literários que eram escolhidos como pretextos para lições de gramática e não para serem lidos, como mostra o documento:

O Ensino de Língua Portuguesa tem sido marcado por uma sequenciação de conteúdos que se poderia chamar de aditiva: ensina-se a juntar sílabas (ou letras) para formar palavras, a juntar palavras para formar frases e a juntar frases para formar textos. Essa abordagem aditiva levou a escola a trabalhar com "textos" que só servem para ensinar a ler. "Textos" que não existem fora da escola e, como os escritos das cartilhas, em geral, nem sequer podem ser considerados textos, pois não passam de simples agregados de frases (BRASIL, 1998b, p. 35)

Menos de uma década depois da publicação desse documento e um pouco mais de duas décadas das influências desse campo de

da influência de intelectuais das Universidades e do Ministério da Educação, ocorrendo nas avaliações do INEP (SAEB, PROVA BRASIL) e das secretarias de educação dos estados (SARESP) e municípios (PROVA DA CIDADE). O mercado didático, seguindo instruções normativas dessa tendência, aplicou as influências ao seu modo - é o que veremos adiante. 
autorias, os formadores de professores, autores de livro didático e responsáveis pelos setores técnicos do ensino de Língua Portuguesa/alfabetização, em suas intervenções, parece terem levado tudo ao pé da letra o que seus mestres abriram de possibilidades.

A aplicação direta e militante dessas influências pode ser vista nos manuais didáticos aprovados pelo PNLD, nos documentos oficiais, nos materiais didáticos encaminhados às escolas e nas avaliações e projetos do MEC/INEP e das Secretarias estaduais e municipais que circulam hoje sob um razoável consenso, tanto nas universidades como nos mais diversos setores da educação brasileira, sobretudo na área de alfabetização62. A busca do texto que realmente circula, 0 texto significativo do universo de letramento do aluno, a estruturação do gênero, a relevância do suporte e do portador de texto, a busca do ambiente de letramento do aluno - tudo isso, paradoxalmente, acabou resultando no afastamento da leitura crítica e do texto literário, em prol de um pragmatismo com contornos de neoliberalismo. O tiro contra os tradicionalistas saiu pela culatra, pois a prática que se observa hoje não é muito diferente daquela criticada por eles, e, em alguns aspectos, a situação até piorou. Talvez as grades de gêneros dos PCN tenham ensejado essa "diversidade" pela "diversidade", que parece, como veremos, não enxergar as singularidades da infância, impondo sobre ela gêneros e textos de uma discursividade adultocêntrica (propaganda, logomarca, texto instrucional, reportagem, notícia etc.).

62 É preciso dizer que esse consenso em torno da abordagem sócio-histórica ou mesmo da construtivista, ou ainda em torno das teorias enunciativas de Bakhtin, contam com um amplo estado da arte e este é muito bem articulado nacional e internacionalmente, sobretudo nos países de língua latina. Mesmo nós que partimos de concepções e campos de estudos diferentes destes, reconhecemos que esses campos se formularam e ainda se formulam com todos os cuidados teóricos possíveis - haja vista os estudos em torno do círculo de Bakhtin e dos psicólogos soviéticos Vigotski, Lúria, Leontiev e outros. O que parece fazer água é o modo como esse arsenal teórico é levado para a prática ou, mais grave ainda, como atravessa as políticas dos governos e legitima aplicações, muitas vezes com resultados contrários ao que os próprios autores propunham em suas obras. 
Se o polo negativo dessa contenda, o tradicionalismo, parecia ter como pano de fundo o reacionarismo da ditadura militar, o outro, sob a bandeira de pensadores de correntes neomarxistas, acabou, consciente ou inconscientemente, tangido pela política neoliberal cuja palavra de ordem é o mercado. A educação parece ter acompanhado pari passu o que se deu na política brasileira: as vozes de oposição, que lutaram contra a ditadura, que brandiam o gládio da defesa dos trabalhadores, acabaram sendo absorvidas pela lógica do capital financeiro internacional, em que o valor utilitarista e de mercado ditam e editam os demais valores humanos.

Nas páginas seguintes, apresentaremos alguns exemplos que, apesar de não constituírem uma pesquisa quantitativa ampla, serão suficientes para sustentar essa nossa crítica. Empreenderemos uma análise, a partir de uma compilação de material oriundo das avaliações da Prova Brasil, SARESP e Prova São Paulo e, ainda, de algumas atividades extraídas de manuais didáticos bem classificados nas avaliações do Programa Nacional do Livro Didático-PNLD/201063. Acrescentaremos também algumas informações extraídas do cotidiano de duas pesquisas, uma já empreendida, outra ainda em andamento; a pesquisa concluída foi realizada na Escola Estadual Keizo Ishirara64 (zona Oeste de São Paulo) e foi financiada pela FAPESP - dela já se publicaram um artigo científico (Belintane, 2010a), vários artigos de divulgação, uma dissertação de mestrado já defendida (Lucas, 2010) e mais duas outras em fase de finalização (Prol Otero, 2011; Giorgion, 2011). A outra é uma pesquisa em rede, envolvendo três pólos (FE-USP/Escola de Aplicação; UERN, campos do Sertão do Rio Grande do Norte, mais precisamente na cidade de

\footnotetext{
63 Reconhecemos, como afirma Batista (2003), que a má formação do professor é um dos elementos que parecem justificar a simplificação crescente dos manuais didáticos; no entanto, abrimos aqui um parêntese, deixando de fora essa já notória formação do professor, e apontamos mais diretamente para os intelectuais e empresas (algumas ONGs) que instrumentalizam as políticas de educação dentro dos governos.

64 Doravante denominada PROJETO KEIZO
} 
Pau dos Ferros, associada a uma escola da rede estadual do RN; UFPA - Faculdade de Educação, campus de Belém, associada a uma escola estadual. A primeira pesquisa será explicitada no próximo capítulo, pois embasará uma parte de nossas reflexões e de nossas propostas; a segunda, ainda em andamento, contribuirá com alguns dados, entre outros, a análise dos três livros didáticos enviados pelo PNLD nas três escolas do projeto. A seguir iniciaremos a análise dos materiais oriundos dos governos (parte I) e, logo após, voltaremos a rediscutir as diferenças entre as linhas que hoje prevalecem e as que meu grupo de pesquisa vem tentando esboçar (parte II). 
1. PDE - PROVA BRASIL - MATRIZES DE REFERÊNCIA, TEMAS, TÓPICOS E DESCRITORES (ENSINO FUNDAMENTAL) (BRASIL, 2008/2009)

Trata-se de um documento de 200 páginas, no formato de livro, que apresenta a "PROVA BRASIL", como uma decorrência do direito de aprender. Já no título deixa claro que é em nome do direito que a Prova Brasil vai ser apresentada. Após o primeiro parágrafo, já temos a citação de um excerto de Antonio Nóvoa65, que vem para situar o leitor dentro de uma trilha ideológica bastante comum na Educação hodierna, a ideia de educar para integrar e libertar o indivíduo. Assim, a Prova Brasil seria uma das maneiras de verificar se o aluno está aprendendo as competências cognitivas básicas da cidadania. Em razão de certa equanimidade do direito às competências cognitivas, o documento defende a pertinência da "padronização" e do "uso de medida". Na sequência, procura mostrar a escala de pontuação da Prova Brasil, que vai de 0 a 500. Após apresentar um "item" (uma questão) para ilustrar os pontos dessa escala e o efeito que o posicionamento das escolas (nessa escala) pode ter sobre o ensino no Brasil, o documento apresenta um conjunto de questões de

\footnotetext{
${ }^{65} \mathrm{~A}$ citação abrupta até parece inofensiva, mas é um traço discursivo marcante do pesquisador brasileiro da área de educação, que marca sua preocupação em logo respaldar o que diz em alguma autoridade consensual. Assim, a expressão "segundo fulano", dá o tom de tudo no país, ainda terceiro-mundista no campo da educação; é preciso (a CAPES manda) se atrelar a autoridades internacionais, ainda que a nossa realidade lance seus gritos esganiçados e destoe dos gritos europeus e americanos. Nóvoa, Sacristán, Hernandes, Bronckart, Schneuwly, Perrenoud, Ferreiro etc constituem um batalhão de frente, que vem para nos definir "competências" e "habilidades", "pedagogia de projetos", "alfabetização construtivista", e constituir uma educação contemporânea para o pobre da escola pública. Enquanto isso, as escolas privadas, onde estudam os que entram nas grandes universidades públicas, continuam com seus currículos repletos de conteúdos tradicionais, que lidam com a tradicional interpretação de texto e com a leitura obrigatória do texto literário.
} 
provas já aplicadas nos últimos anos (SAEB e PROVA BRASIL). Ainda nessa introdução, encontra-se a explicação mais interessante para a nossa crítica, o cruzamento das Matrizes de Referência - que em 2001, foram atualizadas em razão da ampla disseminação, pelo MEC, dos Parâmetros Curriculares Nacionais (PCN) (p. 13) - com uma nova metodologia estatística conhecida como Teoria de Resposta ao Item, TRI, que tem permitido, entre outras coisas, a comparabilidade dos diversos ciclos de avaliação. (p. 12). As matrizes de referências (MR) e a TRI se cruzam para garantir certa cientificidade à comparação entre os diversos ciclos do ensino (p. 12). Na nossa opinião, só faltou averiguar se o campo da leitura pode ser expresso por essas "referências" e se cada questão pode de fato constituir um item avaliável nos moldes preconizados pela TRI. De qualquer modo, faltam também análises epistêmicas sobre essa associação, ou seja, indagar se do ponto de vista metodológico, a TRI e a Tábua de Habilidades, assim associadas, poderiam dar conta do campo da leitura ou mesmo do leitor em formação.

As questões apresentadas como modelos para que os educadores entendam essa associação mostram o quanto esse conjunto de questões não poderia, em hipótese alguma, orientar o ensino da leitura - embora isso pareça ser desejável no documento (p.24) e até já venha ocorrendo, por exemplo, nas redes estadual e municipal públicas de São Paulo, onde as escolas começaram a basear suas intervenções no exemplário das avaliações do SARESP e da PROVA CIDADE DE SÃO PAULO, com o objetivo de melhorar a performance nas próximas edições do processo avaliativo. $O$ resultado pode ser (já vem sendo!) bem desastroso. É isso que aqui pretendo demonstrar, com o objetivo de dar continuidade à comparação entre a formulação pragmática dessas concepções e a que venho tentando desenvolver. 
Cada questão apresentada - diferentemente, por exemplo, das propostas pelo PISA de $2009^{66}$, que procura integrar habilidades em competências mais amplas - procura isolar uma habilidade ou "descritor" em cada teste, como se a soma dessas habilidades e desses itens pudesse fornecer a medida do quanto o aluno pode ou consegue ler. Como se pode facilmente averiguar, os textos postos lá não são para serem lidos integralmente ou deles serem extraídas mensagens em diversos níveis de compreensão, mas simplesmente para testar um item, ou seja, uma habilidade. Tomemos o exemplo que aparece na página 7 - apesar de ter sido posto ali apenas para ilustrar a relação entre avaliação de um item e possibilidades de intervenção, vamos abordá-lo, pois se trata de uma questão presente em avaliações anteriores. Coloca-se um belo poema de Manuel Bandeira, "O bicho", e dele se extrai uma atividade de interpretação (com solução duvidosa). Vale a pena transcrever o poema e a questão:

O bicho

Vi ontem um bicho

Na imundice do pátio

Catando comida entre os detritos

Quando achava alguma coisa

Não examinava nem cheirava:

Engolia com voracidade.

O bicho não era um cão,

Não era um gato.

Não era um rato.

O bicho, meu Deus, era um homem.

66 PISA - Programme for International Student Assessment - No portal do MEC havia três questões modelos, mas na hora de referenciar não reencontramos a página. Passamos, portanto o link abaixo que remete para a REVISTA NOVA ESCOLA, que também publicou as três questões modelos.

http://revistaescola.abril.com.br/planejamento-e-avaliacao/avaliacao/pisa-alemranking-621959.shtml?page $=1$ e fez comparações com a PROVA BRASIL, evidenciando que naquele há questões dissertativas, que cobram reflexões e tomadas de posição diante de textos polêmicos. 
Segue-se a questão:

o que motivou o bicho a catar restos foi
A) a própria fome.
B) a imundice do pátio.
C) o cheiro da comida.
D) a amizade pelo cão.

Não é difícil perceber que a compreensão de um poema como este de Manoel Bandeira não é tão direta e óbvia como supõe a resposta (alternativa $A$ ). Outros motivos poderiam ser inferidos (se o leitor não fosse tão militante), por exemplo, o abandono, a loucura. Em nosso campo de vivências, é possível fazer a hipótese de que boa parte dos famintos busca comida criteriosamente, só os que chegam aos limites do abandono e da loucura comem com essa voracidade de bicho. O poema fala mais de abandono absoluto de um ser humano do que da fome. Diante das alternativas, o aluno, para não errar, extrai a resposta por meio da comparação entre os "distratores" (respostas erradas e absurdas) e não de sua própria leitura do texto, pois outras poderiam ser as respostas, se a questão fosse aberta, como, por exemplo, algumas da prova do PISA.

Prosseguindo nos exemplos de "itens", o documento segue nessa toada, ofertando um texto para cada habilidade. Por exemplo, a questão seguinte, página 25 , apresenta um texto informativo e dele se procura extrair a habilidade de localizar uma informação solicitada, que pode estar expressa literalmente no texto ou pode vir manifesta por meio de paráfrase (p.25). O texto apresentado, "O disfarce dos bichos", possui dois parágrafos, ambos com cinco linhas; vejamos o primeiro: 
porque o graveto era um inseto conhecido como

"bicho pau". [...]

$[\cdots]$

O bicho-pau se parece com
(A) florzinha seca.
(B) Folhinha verde.
(C) Galhinho seco
(D) Raminho de planta.

Não transcrevemos o restante do parágrafo e, nem o segundo, por não ser necessário, já que a questão incide no início do primeiro parágrafo, pois é possível extrair a resposta correta lendo apenas metade do primeiro parágrafo; e mesmo para comparar os demais distratores não seria necessário ler o segundo parágrafo, já que o texto é proposto apenas para se avaliar uma habilidade específica. Como se dizia nas críticas mencionadas anteriormente: trata-se de um "texto-pretexto", mas piorado, pois apenas um fragmento será o pretexto, o resto pode ser abandonado.

O texto seguinte é uma tirinha do Maurício de Sousa, cuja interpretação traz mais uma ambiguidade, que levou um distrator a ser confundido ( $34 \%$ assinaram a alternativa A como a correta) com a resposta correta, alternativa C (31\%). Vejamos:
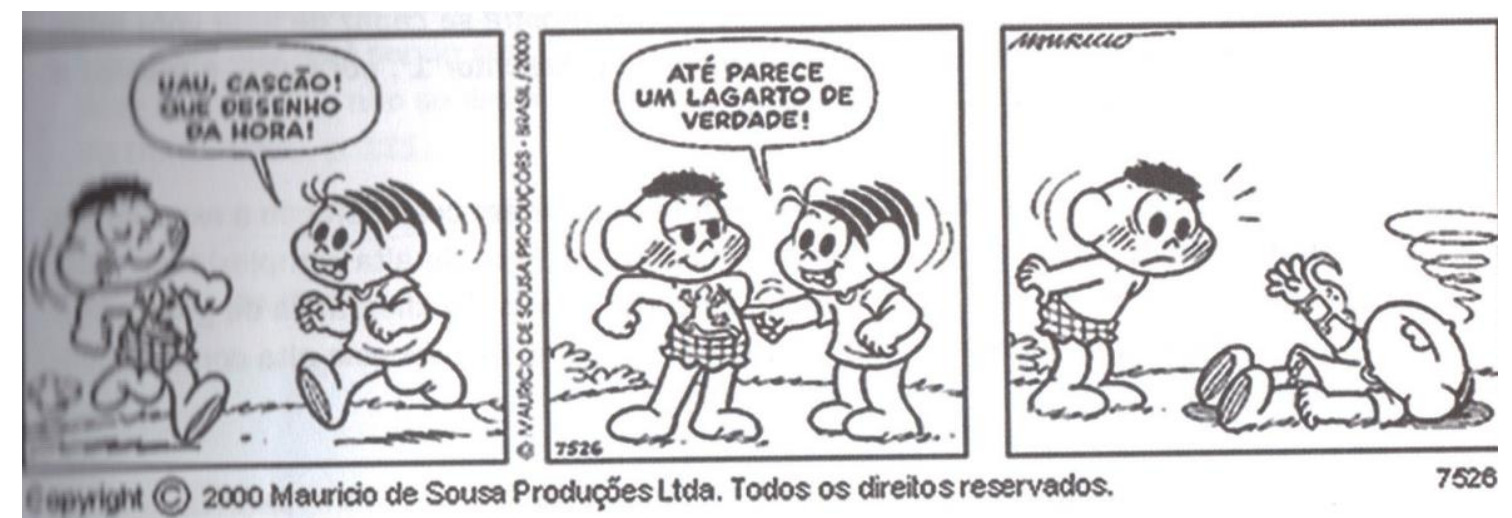
Questão:

No primeiro quadrinho, a Mônica pensou que o lagarto era um desenho. Ao usar a expressão "DA HORA" ela deu a entender que o desenho
(A) tinha acabado de ser feito.
(B) durava somente uma hora.
(C) era moda entre a turma.
(D) deveria ser usado na hora.

Dá pra entender o porquê de somente $31 \%$ escolherem a alternativa C (correta), pois a expressão da hora pode sim ter outros sentidos como "muito legal", "bem feito" - não é muito fácil para uma criança de dez anos entender a resposta correta, ou seja, que a expressão deve ser compreendida como "moda", pois o desenho poderia ser "da hora" exatamente por ser diferente, não ser "moda". Bem, além da má formulação da resposta correta - como sempre - a essência da tirinha não foi abordada, pois o que a torna interessante para o leitor é a confusão entre uma imagem e seu referente, ou seja, um desenho que, de repente, está vivo e vai para a mão da Mônica, provocando o desmaio. Mas, o que se queria aferir era apenas uma habilidade, ou seja, extrair o sentido de uma palavra ou expressão no texto, ou seja, dando a determinadas palavras seu sentido conotativo. (p. 27)

Todas as demais questões prosseguem dessa forma, um texto ou até mais de um, para averiguar isoladamente apenas uma habilidade. Bem, aqui até poderíamos aceitar o argumento de que esse cotejamento um a um (um texto para uma habilidade) foi pensado apenas para exemplificar com clareza cada habilidade, o que não é verdade, pois as avaliações seguem o mesmo padrão. Em geral, as exigências mais importantes que um texto colocaria ao leitor, de uma forma complexa, enredando habilidades, não são 
tocadas pelo instrumento de avaliação. Em nome da diversidade de gênero, do uso e da circulação social do texto e da certeza de que o "item" está sendo contemplado, afere-se apenas um aspecto de cada texto.

No final do documento (p.104), nas Considerações Finais sobre a prova de Língua Portuguesa, chama-se a atenção para a competência estabelecida no Tópico IV, por tratar-se de elementos que constituem a textualidade, ou seja, aqueles elementos que constroem a articulação entre as diversas partes de um texto: a coerência e a coesão. Logo a seguir, toca-se no efeito de sentido decorrente do uso da pontuação e de outras notações, mostrando que uma competência que deve ser trabalhada desde os primeiros anos do fundamental se comporia das habilidades que permitem compreender a função desses sinais e notações, para além das classificações da gramática normativa, ou seja, mais em função dos efeitos de sentido que causam no leitor. Outra competência que se põe em destaque é o conhecimento da variação linguística, que é interpelada em nome do respeito à variação da fala e da inclusão dos alunos considerados linguisticamente fora do processo de ensino/aprendizagem ( $p .104$ ), que também vai se configurar como um "item" e soar com absoluta artificialidade nos testes propostos. Desta forma, pouco se valorizam as potencialidades do regional em obras literárias modernas, como as de Guimarães Rosa, Manoel de Barros, Zé da Luz, Patativa do Assaré e de tantos outros, ou seja, deixa-se de mostrar o essencial: que as normas regionais rendem literatura tanto quanto a tal norma culta. Em vez disso opta-se pelo politicamente correto, pela ideia de "respeito", assumindo a carga semântica desse verbo, que no Brasil é quase pejorativa, pois respeita-se o que a sociedade não valoriza (o pobre, o deficiente, a fala regional etc.). O que se deveria fazer é mostrar o valor da fala regional, sua potencialidade expressiva - só se pode fazer isso por meio da boa literatura. 
O que também fica claro nessa finalização do caderno é que mesmo para as habilidades que ocupam o topo da tabela, ou seja, as que compõem as competências e habilidades mais complexas, Tópico IV Coerência e Coesão no Processamento do Texto; Tópico V. Relações entre Recursos Expressivos e Efeitos de Sentido, as questões que se apresentam continuam nesse ramerrame de avaliar uma habilidade por texto, sem exigir de fato sua leitura completa, tendo até mesmo algumas que podem ser resolvidas com a leitura apenas da consigna. Vejamos a da página 102, em que se apresenta um pequeno conto de Ignácio de Loyola Brandão, $O$ homem que entrou pelo cano, que aqui nem precisamos transcrever, pois o teste novamente dispensa o texto; vejamos, portanto apenas a consigna e o teste:

Na frase "Mamãe, tem um homem dentro da pia." ( . 9, o verbo empregado representa, no contexto, uma marca de
(A) registro oral formal.
(B) registro oral informal.
(C) falar regional.
(D) falar caipira

Bastaria ao aluno saber o sentido das expressões técnicas registro oral formal, registro oral informal, para assinalar a correta. No entanto, pelo desempenho dos alunos $(A=35 \% ; B=33 ; C=26 \%, D=$ $6 \%$ ), só dá pra afirmar que $6 \%$ dos alunos não sabem o que é "falar caipira". Também não dá para entender por que transformar conhecimento de nomenclatura técnica da linguística ( o termo "registro") em habilidade.

O exemplo da página 95 é ainda pior que esse, pois um texto (de gosto bem duvidoso) de 31 linhas ( 7 parágrafos) é utilizado para testar o descritor 17, que explicita a habilidade: Identificar o efeito de sentido decorrente do uso da pontuação e outras notações. Vejamos: 
No trecho "...nem tomo muito refri (celulite!!!)" ( . $14)$, a repetição do "ponto de exclamação" sugere que a personagem tem
(A) incerteza quanto às causas da celulite.
(B) medo da ação do refrigerante.
(C) horror ao aparecimento da celulite.
(D) preconceito contra os efeitos da celulite.

Fica clara aqui a intenção de transpor para a ideia de que se deve estudar a fala cotidiana, a fala em uso. Só nos resta perguntar onde o aluno da escola pública pode ir com esse tipo de conhecimento que a língua Ihe dá intuitivamente.

Ainda nessas considerações finais, há um parágrafo que parece reconhecer os limites desse tipo de avaliação por "item":

\begin{abstract}
É imprescindível ressaltar que as formas de se trabalhar a leitura não se esgotam em apenas um item no desenvolvimento de uma habilidade. Na verdade, são inúmeras as possibilidades que o professor pode lançar mão em sala de aula, e que, em uma avaliação como esta, devido às limitações operacionais e à metodologia utilizada, as quais permitem medir apenas uma habilidade por item, não são passíveis de serem mensuradas. (p. 104)
\end{abstract}

Estariam os avaliadores reconhecendo que a complexidade do campo da leitura não combina com a Teoria de Resposta ao Item? Se for isso, aqui fazemos questão de parabenizar o autor desse trecho e sugerir que ele insista nesse rumo. No entanto, no parágrafo seguinte, as considerações recomendam que, para ajudar o aluno a desenvolver as habilidades e competências,

o professor precisa considerar a utilização dos gêneros textuais diversificados para que os alunos adquiram familiaridade com temas e assuntos variados. Para isso seriam textos que despertem interesse e façam parte de suas práticas sociais e arrematam dizendo que a construção da competência linguística dos alunos depende necessariamente da variedade de gêneros textuais que circulam na escola e das práticas de letramento de que participam. (p. 105) 
Estão aí, portanto, em um documento oficial, as balizas que se vêm adotando - com muita tranquilidade, pois a repetição dos termos chave dessa concepção dominante já ganhou um status discursivo tal que qualquer dissensão é considerada absurda ou esquisita. Até mesmo a mídia silenciou, pois deve ter achado interessante o tecnicismo do relatório da TRI e visto nele alguma coisa bem fundamentada na seriedade das estatísticas.

Como voz dissonante, apresentaremos, ainda neste capítulo, algumas ideias (algumas até tradicionais) que contrariam esse amplo consenso. Mas, antes disso, ainda pretendemos retirar mais alguns exemplos de instrumentos de avaliação, tomando o SARESP e a PROVA SÃO PAULO com a intenção de mostrar o espalhamento das concepções de língua e de texto já nesse amplexo com a TRI. Apresentaremos essas críticas em dois tópicos, que deverão revelar esse estranho comprometimento dos avaliadores com 0 neoliberalismo, com o mercado e, ainda, a adoção dessa postura afrouxada que permite essa substituição dos textos da boa literatura por textos bem triviais ou mesmo essa aceitação passiva do discurso estatístico que rege a escolha dos textos e faz deles apenas "itens" de avaliação.

Essa indiferença e permissividade, com certeza, não advêm diretamente da obra de Bakhtin, de Bourdieu, de Pêcheux ou mesmo dos autores brasileiros que partiram dessas correntes. Lembram mais uma deriva sem controle dos termos que se foram somando e se sedimentando no "uso da língua" e dos "gêneros" que matriciam o ensino de Língua Portuguesa e da Alfabetização (termos como "práticas de letramento do aluno", "uso da língua", "função social da escrita", "diversidade de gêneros", "universo de letramento" e outros) e que se opuseram à tradicional ideia de textos ou gêneros alienantes (distantes da realidade do aluno pobre, que favorecem mais a elite dominante) ou da escolarização do texto (o tal texto-pretexto). 
Talvez também lembrem certo modo de aceitação da universidade terceiro-mundista em que as teorias assimiladas das grandes universidades do primeiro mundo têm o poder de falar mais alto do que os dados oriundos da realidade brasileira.

\section{ALGUNS EXCERTOS DO SARESP}

Abordo aqui apenas alguns cadernos da $4^{a}$ série das avaliações de 2007, que são as últimas disponíveis. A partir de 2008, as questões passaram a ser reutilizadas nos anos seguintes como forma de melhorar a comparação entre um ano e outro, portanto seus exemplares não estão disponíveis ${ }^{67}$.

De maneira geral, prevalece a teoria da diversidade de gênero, com uma distribuição que segue mais o menos o seguinte padrão:

1. Texto literário, em geral uma fábula ou conto de fada europeu;

2. Uma história em quadrinho;

3. Um texto de divulgação científica;

4. Uma notícia de revista ou suplemento infantil;

5. Uma publicidade, rótulo ou outro gênero do mercado;

6. Um texto instrucional.

Das trinta questões, seis trazem textos literários (conto de fadas ou fábula), as demais se distribuem entre outros gêneros. As vinte e quatro questões contemplarão o universo de letramento do mundo urbano, onde circulam o cartaz da propaganda, a revista infantil, o suplemento do jornal. Nesse afã de cercar o suposto universo de letramento da criança, a literatura fica para um plano

\footnotetext{
${ }^{67}$ Sobre essa situação também cabe uma crítica, pois em nome de se preservar questões para repeti-las e com isso garantir a comparabilidade das performances ano a ano, retiram-se os instrumentos de avaliação do alcance da crítica. Só pra se ter uma ideia desse sigilo citemos um fato recente: em maio deste ano (2011), enviei mensagem ao INEP, solicitando as avaliações dos últimos anos, a resposta foi a seguinte: Como o foco da avaliação é a unidade de ensino, não são divulgados resultados ou emitidos certificados de desempenho individual dos alunos. (falabrasil@mec.com.br)
} 
menor: apenas $20 \%$ do contínuo. Se, no passado, o texto literário ocupava em uma avaliação $60,70 \%$ da prova, como ainda acontece nos grandes vestibulares, a atual preocupação com a cidadania e com a usabilidade da língua reduziu o texto literário a um ínfimo percentual. Além dessa redução, ainda é problemática a escolha e o nível discursivo dos demais textos, que em geral são assimilados de forma anódina, sem relevância discursiva. Veja-se, por exemplo, que situação mais anti-bakhtiniana a exploração desta publicidade:

Atenção: Para responder às questões de números 22 a 26, leia a propaganda abaixo.

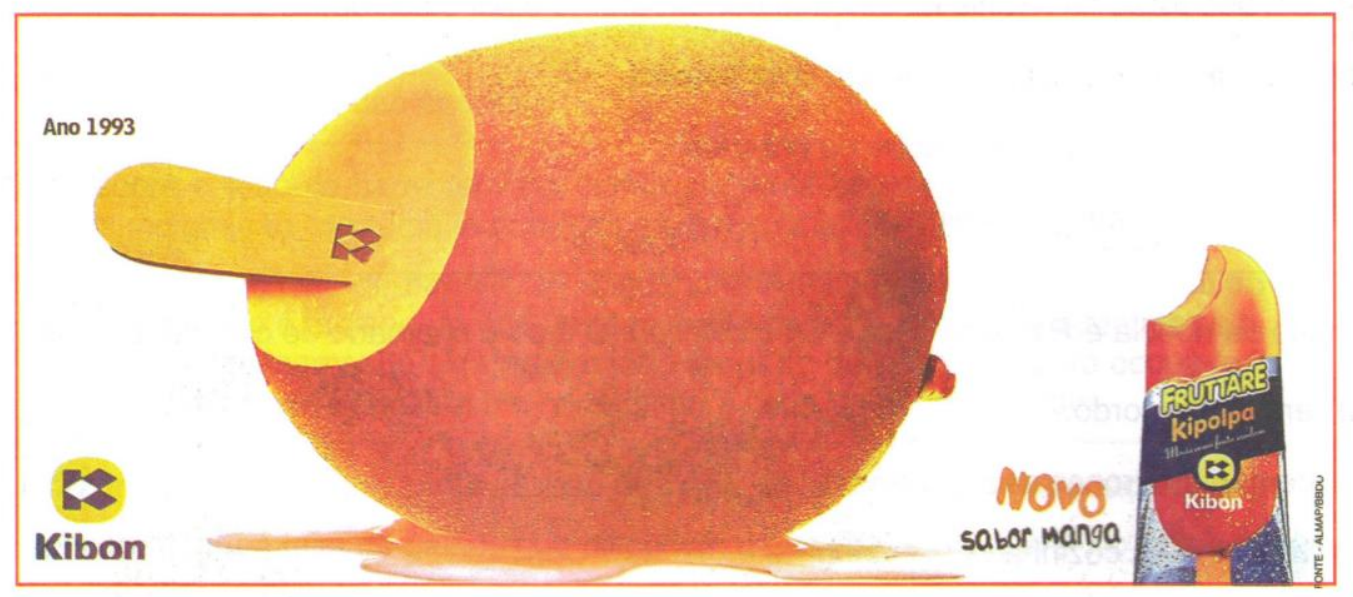

Vejamos as questões: 
22. Onde você poderia encontrar esta propaganda?
(A) No Posto de Saúde.
(B) Na padaria.
(C) No mural da sala de aula.
(D) No consultório do dentista.

23. Esta propaganda foi feita pensando em
(A) todas as pessoas sem distinção de idade ou sexo.
(B) só nas pessoas que gostam de fruta.
(C) somente nas crianças.
(D) apenas nos adultos.

24. Este sorvete é diferente dos outros da mesma marca por ser
(A) o lançamento de um novo sabor.
(B) o que tem a maior fruta.
(C) o mais vendido da Kibon.
(D) a manga, a melhor fruta do mundo.

25. O nome do sorvete é "Fruttare Kipolpa". Ele chama-se assim porque é um sorvete
(A) bonito e diferente.
(B) que tem o nome da fruta.
(C) feito com polpa de fruta.
(D) estrangeiro.

10

SARESP-LP-4EF-Manh

Como não enxergar, nesta operação, a presença do neoliberalismo com toda a sua força pragmática recobrindo as teorias revolucionárias das décadas de oitenta e noventa? Tudo parece correto, dentro do modelo: trata-se de um dos gêneros do contínuo da diversidade, um texto do cotidiano do aluno, de seu universo de letramento (texto real, uso da língua), que, com tais características, tem condições de constituir um ITEM avaliável (exigência da TRI), ou seja, uma habilidade pode ser extraída de sua leitura, independentemente de seus outros enlaces discursivos. 0 neoliberalismo se perguntaria: para que ter preconceito com a publicidade? Não se trata de um estrato de uso da língua? Talvez aqui a empresa (isso não seria um bem?) poderia até arcar com parte do 
custo da prova, já que vai divulgar seus produtos? E a criança? Ora, de qualquer forma ela já não seria cingida por esse tipo de discurso? Não tem todas as características para fazer sobre ele incidir a reflexão como se apregoa nos PCN? Cá pra nós, fica a certeza de que, como é impossível desconstruir o discurso publicitário para essa faixa etária, estamos assistindo ao ingresso da publicidade também na sala de aula - do mesmo modo que, com a complacência intelectual neoliberal, ela se instalou no cinema, nas redes sociais e em outros setores da vida. Drummond anteviu essa invasão e a traduz magistralmente no poema Eu Etiqueta (Drummond, 1992 p. 1018).

Para completar o exemplo, notemos como os testes 24 e 25 são textos "autênticos": como a publicidade traz explicitamente o nome do produto, Kipolpa, a criança é obrigada a concordar com a alternativa correta, que ele é honestamente feito de polpa de manga, ou seja, "se se trata de uma propaganda" - diz o neoliberalismo enviesado no espaço interdiscursivo - "por que não a alternativa correta não corroborar sua intenção?" Na outra versão da prova (turma da manhã), a empresa beneficiada com a publicidade é a Philips. Novamente temos as alternativas corretas atestando a qualidade do produto. A Philips agradece ou remunera os avaliadores? Se a palavra é aí uma arena de luta como diz Bakhtin (1995 p.66), a contenda vem sendo nitidamente ganha pelo mercado.

O balanço geral entre os trinta testes, além de revelar esse enfraquecimento da literatura e essa abertura para os textos "úteis" (jornais, textos instrucionais, publicidades), mostra também uma exploração superficial dos textos, prevalecendo a leitura direta (sem inferências mais fortes), com pouca ênfase nos efeitos de sentido mais produtivos e inteligentes ${ }^{68}$. Como a prova deve compor um

\footnotetext{
${ }^{68}$ Não era exatamente isso que denunciavam os intelectuais das décadas de 80 e 90 (Geraldi, Marcuschi, Kleiman, Chiappini, Lajolo, Zilberman e outros?).
} 
espectro para uma faixa etária bem ampla, da quarta à oitava séries (atualmente, do quinto ao nono ano), os "itens" e "habilidades" constituiriam um leque aberto onde se poderiam situar os diversos níveis de cada ciclo, ou seja, seria possível dizer em quais habilidades previstas para a quarta série o desempenho dos alunos da oitava série teria ou não condições de se situar - essa preocupação em isolar bem cada habilidade leva a esse aborto da complexidade discursiva que a leitura de um texto põe em jogo.

\section{A PROVA DA CIDADE}

Aplicada em 2009, para o quarto ano do ciclo I, a avaliação da rede municipal de São Paulo parece extrapolar todos os limites do bom senso. Se o SARESP ainda mantém certa preocupação com uma leitura mais ampla dos textos escolhidos (pois põe diversos itens para um mesmo texto, ainda que redundando na superficialidade), a Prova da Cidade, além de estreitar ainda mais a interpretação, comete erros elementares e até absurdos. Bem provável que seus autores estejam ainda mais equivocados quanto ao paradigma construtivista ou "sociointeracista/bakhtiniano" do que os do SARESP, pois exageram absurdamente na escolha de textos banais, supostamente do "universo de letramento da criança", dispensando o texto literário de boa qualidade e fugindo do texto de maior extensão. Vejamos a diversidade, depois vamos nos ater a certos detalhes neopositivistas que fariam Bakhtin e Vigotski tremerem em seus túmulos e poderiam fazer nossos linguistas e educadores das décadas de oitenta e noventa reverem a pujança de seus argumentos quando recomendam a transposição de teoria para a prática, sobretudo os que vêm na esteira dos suíços Bronckart e Schneuwly ${ }^{69}$.

\footnotetext{
${ }^{69}$ Constatável tanto na proliferação do nome desses autores em coletâneas que abordam a questão dos gêneros na escola, como nos próprios PCN (BRASIL, 1997b, p. 26).
} 


\section{GÊNEROS E QUESTÕES DA PROVA DA CIDADE}

Notícia (curta, de seis linhas) para dois testes que exploram leitura direta do texto, questões 1 e 2;

Receita: de suco de abacaxi e maçã, que apresenta 4 ingredientes e para o Modo de Fazer apenas uma linha. Cobram-se as seguintes habilidades:

(3) para que serve a receita (função social do texto), fornecendo a resposta correta: C - Ensina a preparar um suco.;

(4) leitura direta de informações de um dos itens dos ingredientes: 1 maçã descascada, sem sementes e picada, deve ser parafraseada por a maça deve ser picada e sem sementes;

(5) Que gênero é o texto: uma receita. O mais curioso é que aqui a adesão à teoria parece impedir os examinadores de perceber que nesse texto, apesar de ser uma receita, a lista de ingredientes prevalece sobre o modo de fazer, então o "para-que-serve-o-texto" fica meio complicado, de vez que muitos alunos devem ter assinalado a alternativa ( $B$ ): fazer uma lista de compras, pois a verdadeira, que é (C) ensinar a preparar o suco, só tem uma linha e traduz uma ação que nem precisa de ensino, pois explicita apenas duas ações comuns: pôr os ingredientes no liquidificador e bater. Talvez, para a criança, o mais complicado seria memorizar a lista de ingredientes, sendo assim, a utilidade prática estaria na lista e não no modo de fazer. Aqui, como em outros pontos da prova, a teoria dos gêneros, enviesada pelo utilitarismo que traduz a ideia de universo de letramento, fica acima do ato de ler.

6. Um inusitado "texto instrucional", que é mais publicidade do que texto instrucional, pois, por trás do truque de se ensinar como se desenha a boneca Hello Kitty, está a divulgação do produto. Vejamos: 
6. Leia o texto a seguir para saber como desenhar uma boneca.

\section{Para desenhar a Hello Kitty}

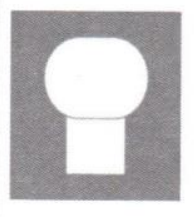

Comece fazendo os traços para a cabeça e o corpo, sem apertar o lápis.

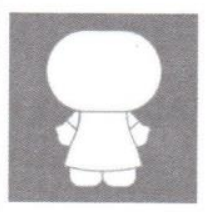

Desenhe os braços, os pés e o vestido.

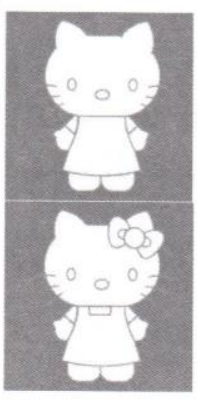

Faça as orelhas, os olhos, o nariz e os bigodes

Agora desenhe um pequeno decote no vestido e um detalhe importante: o laço na orelha esquerda.

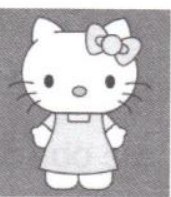

Fonte: Recreio. Disponível em: http://recreionline.abril.com.br/

atividades/desenhe/atividade_53007.shtml?atividades. Acesso em: 2008.

Para desenhar os braços, os pés e o vestido é preciso fazer primeiro

(A) o decote no vestido.

(B) o laço na orelha esquerda.

(C) as orelhas, os olhos e o nariz.

(D) os traços da cabeça e o corpo.

PROVA DA CIDADE - SEGUNDO SEMESTRE DE 2009 
7. Poema infantil - Apesar de o poema pertencer a uma autora de bom nível, Tatiana Belinky, tanto pela temática (comida) como pela estética, não é um poema dos mais interessantes. Vejamos:

\section{Que Delícia!}

Comida gostosa.

Ai que coisa louca

Que só de pensar

Me dá água na boca!

Batata assada,

Com manteiga e sal

Derrete na boca

Prazer sem igual!

Domingo cai bem

A macarronada,

No sábado - hum!

Lá vai a feijoada!

A consigna propõe: a palavra sal rima...Explora, de uma maneira simplória e direta, apenas uma das rimas (com igual) e não a sua repetição ao longo do poema. O fato mais interessante sobre as rimas do poema seria o modo como elas o estruturam, o esquema abcb, ou seja, em cada estrofe rimam apenas dois versos, o segundo e o quarto, o que facilita a construção do poema. Levar o aluno a perceber isso - o modo de construção do poema - poderia ser uma contribuição mais interessante.

8. A questão tenta explorar a expressividade do uso de sinais de pontuação, no caso a exclamação.

Em "prazer sem igual !", o ponto de exclamação reforça a ideia de
(A) alerta.
(B) desejo.
(C) tristeza.
(D) espanto. 
Mas novamente se limita a um verso, sem chamar a atenção para o efeito que o uso da exclamação produz ao longo do poema, desde o título à última estrofe, pois o sinal é utilizado quatro vezes. Em vez de fazer uma pergunta mais abrangente, buscando o efeito da exclamação sobre o texto, prefere-se o "item" isolado, despegado das condições mais gerais da leitura. As exclamações dão ao texto um efeito de sentido especial, que reforça o desejo de comer, a atração da comida. Mesmo diante de uma quarta-série, seria possível abordar esse efeito.

9. A questão toma uma expressão do texto comida gostosa e pede seu sinônimo, mas de uma forma que se pode também dispensar a releitura do texto, pois é só contrastar a alternativa (D) saborosa com os demais distratores.

Conto infantil - outra escolha que revela mau gosto estético e ajeitamento para contemplar a tal diversidade de gênero (um conto pequeno toma pouco espaço e contempla a diversidade). Apesar de a autoria ser interessante, Paulo Mendes Campos, o tal continho não passa de uma anedota simplória:

\section{Continho}

Era uma vez um menino triste, magro e barrigudinho, do sertão de Pernambuco. $\mathrm{Na}$ soalheira do meio-dia, ele estava sentado na poeira do caminho, imaginando bobagem, quando passou um vigário a cavalo:

- Você aí, menino, para onde vai esta estrada?

- Ela não vai, não; nós é que vamos nela.

- Engraçadinho duma figa! Como você se chama?

- Eu não me chamo, não; os outros é que me chamam de Zé.

(Fonte: Campos, Paulo Mendes. Para Gostar de Ler: crônicas. São Paulo: Ática, 2000) 
A questão 10 pede apenas que se localize qual é a fala do menino. A questão 11 solicita apenas a extração direta de um dado: $\boldsymbol{O}$ menino do Continho era.... (B) do sertão pernambucano.

Em relação a esses dois últimos textos da prova (poesia e conto), cabe uma boa crítica: escolhe-se e explora-se de forma equivocada o texto literário. Mesmo admitindo que, segundo a teoria utilizada, uma informação direta é um item bem concreto, por que não fazer isso com gêneros em que a informação direta é o que está em jogo, por exemplo, a notícia, etc.? Se se quer "usar" gêneros literários, deve-se escolher o melhor texto possível e explorar o que a arte da literatura tem para oferecer, que é a estética, a expressão que ressignifica a língua, o mundo e as relações humanas, enfim explorar o "uso da linguagem" que permite à criança ir além do imaginário cotidiano e tratar a palavra, a língua e a leitura como campos de mistério, de fantasia, da expressão de si.

No caso desta e de outras avaliações, o texto literário parece não se diferenciar dos demais gêneros "úteis" - nesse sentido, tanto as escolhas dos textos como o tratamento dado às atividades de leitura diferem muito da nossa perspectiva, que foca o "desútil", a fantasia, o jogo linguageiro e suas relações com o inconsciente.

Notícia - Texto publicado no site da UOL, com tema sobre a gripe suína no Brasil. Aqui a incompetência chega ao absurdo, pois os dois testes apresentam problemas. Vejamos:

Leia a notícia a seguir para saber como anda a gripe A no Brasil.

Chegam a 21 casos confirmados de gripe no Brasil; creche é interditada em Campinas (SP)

Do UOL Notícias Em

São Paulo 
O Ministério da Saúde divulgou na noite desta segunda-feira $\left(1^{e}\right)$ que foi confirmado mais um caso de gripe suína, a influenza A (H1N1), no Brasil. A paciente é de Campinas (SP). Com isso, chega a 21 o total de casos confirmados no país.

Esta nova paciente, que está internada e passa bem, teve contato próximo com uma pessoa que pegou a gripe no exterior. Ela trabalha em uma creche que atende a 30 crianças. Todos, incluindo crianças e funcionários do local, bem como seus contatos próximos, estão sendo monitorados pelas autoridades de saúde, segundo nota do ministério.

Por medida de precaução, o Ministério da Saúde afirma que as atividades da creche em questão foram suspensas por dez dias, período de manifestação dos sintomas da doença.

Dos casos confirmados até agora, sete foram de transmissão autóctone (dentro do território nacional), causados por contato com pacientes vindos do exterior. Os casos suspeitos no país são 21 e outros 369 já foram descartados.

De acordo com a Organização Mundial de Saúde, há 17.410 casos confirmados de influenza A (H1N1) em 62 países, e 115 pessoas morreram.

Fonte: UOL Notícias Cotidiano. 01/06/2009 - 21h08. Disponível em:

http://noticias.uol.com.br/cotidiano/2009/06/01/ult7403u81 .jhtm. Acesso em: maio de 2009.

A questão 12 indaga sobre o local da publicação, ou seja, o portador do texto. A resposta do gabarito seria: (B) de um jornal. O esquema de fidelidade ao gênero leva os autores à relação direta: "notíciajornal". Só que o texto fornece até a URL da publicação, ou seja, trata-se de um portador on line, o site da UOL. Reaplicamos essa prova a alunos de $4^{a} / 5^{a}$ séries, considerados bons leitores, que não só gabaritaram a prova com facilidade, como alguns ainda corrigiram essa questão, acrescentando uma alternativa (e), escrevendo após os quatro distratores: "(e) de um site".

Já a questão 13 erra na gramática: o pronome $E L A$, em negrito no texto, se refere a "Esta nova paciente" e não a "ao paciente" (alternativa C), no masculino, pois fica clara a intenção do enunciador no texto em tratar o paciente aqui em seu gênero feminino, indicando inclusive sua profissão (trabalha em creche, onde em geral trabalham mulheres); portanto, a presença dessa contração "ao" não se justifica.

Adivinha - Apresenta-se uma adivinha, que é um gênero de origem oral que, muitas vezes - como a piada, o chiste -, só funciona bem 
na fala, na oralidade, pois o jogo de palavra, ao ser posto na escrita, acrescenta às homofonias certa complexidade gráfica. A questão parece bem formulada, talvez a melhor da prova, mas mesmo assim há certa inadequação na consigna. Vejamos:

14. Leia com atenção e descubra a resposta da adivinha

O QUE É O QUE É
UMA PALAVRA DE SEIS LETRAS
QUE TEM MAIS
DE TRINTA ASSENTOS?

A palavra é:
(A) acento.
(B) bancos.
(C) ônibus.
(D) agudos.

Como esta adivinha é de origem oral, seu "uso" traria o jogo de sentido típico da brincadeira linguística. Leva-se o sujeito a pensar, como resposta, em uma palavra que tenha acento gráfico, mas ao se deparar com o absurdo (não existe palavra com tantos acentos), o adivinhador faria uma retroação para descobrir a homofonia (acento/assento) e, em seguida, o referente da palavra com "trinta assentos". Na questão, a resposta acaba fazendo a função da retroação, o que retira a principal característica da adivinha, que é uma espécie de compreensão de texto na oralidade (Belintane, 2006). Sempre que se usa texto de origem oral na escrita, algo de sua essência se perde. Mas, descontando essa exigência, trata-se da melhor questão da prova, pois é a única que envolve uma inferência mais interessante.

Cordel - apresenta-se uma estrofe de cordel, para simplesmente se explorar a rima, da mesma forma que foi explorada no poema anterior (questão 7), ou seja, sem nenhuma consequência para a releitura do poema: a palavra que rima com brasileiro é... a 
resposta é inteiro. A rima isolada desta maneira já teria sido contemplada em questão anterior, então por que trazer um trecho de cordel para se repetir a cobrança desse item tão isolado, senão apenas para pôr mais um gênero na prova e mostrar que se está contemplando a diversidade de gênero?

Fábula : trata-se de uma fábula da coletânea de Esopo, mas aqui deve ter sido modificada pelo autor da obra referenciada na prova: $O$ livro das Virtudes para Crianças, Willian Bennet. Novamente o texto é posto para se classificar o gênero: o teste 16 pergunta se o texto é...uma fábula. O teste 17 revela um tipo de ambiguidade, sutil, mas que deve ser levado em conta quando se lida com leitura: a leitura do texto mostra que o menino é retratado como brincalhão: "encontraram-nos às gargalhadas", "ainda uma vez ele fez a mesma brincadeira"; "e ele caçoou de todos". Só na moral é que se menciona o termo mentiroso: Ninguém acredita quando o mentiroso fala a verdade. Nos testes, os alunos que leram o texto todo poderiam, pelos termos que apontei, achar que o menino era mais um brincalhão do que propriamente um mentiroso, como afirma a alternativa correta. Há mais pistas para uma criança inferir que o menino era brincalhão do que para inferir que ele era mentiroso; afinal, o texto diz claramente que seu desejo era caçoar, brincar, pregar peças. Já o aluno que não lê o texto, mas procura a palavra diretamente na moral da fábula, não enfrentará esse conflito e acertará mesmo sem ter lido o texto. As fábulas não são tão simples como quer esta questão, pois entre a alegoria e a moral cabem interpretações. Não se pode simplesmente aceitar a fábula e sua moral, sobretudo aos dez anos e este caso é um exemplo, pois o modo como se busca a moral, afirmando se tratar de um mentiroso, pode ser questionado pela boa leitura, pois podemos dizer que é a brincadeira inconsequente que está em jogo e não a mentira. A moral poderia ser outra: a brincadeira de mau gosto, que prega peça às 
pessoas, pode retornar na forma de prejuízo para o próprio brincante. Boa parte das fábulas, como "A cigarra e a formiga", tantas vezes parodiadas, são moralistas demais. Apresentam a alegoria - que encanta as crianças, pois são animais que falam - e encerram abruptamente com a moral. Muitos desses fechos têm que ser questionados. Descontruir a moral das fábulas na quarta-série é atividade importante. Não é o caso da Prova da Cidade e de outras avaliações e até mesmo de muitos livros didáticos que, em nome da teoria dos gêneros, abordam as fábulas sem desconstruí-las a partir de uma leitura crítica. Ou seja, como neste gênero a finalização com uma moral é um elemento estruturante, então o foco na moral parece prevalecer sobre a leitura crítica.

Capa de livro: a teoria parece ter mandado explorar, nesta prova, além da diversidade de gênero, também a de portador, pois uma capa de livro é apresentada para o aluno localizar apenas o título da obra. Ou seja, mais uma vez isola-se um item do complexo fenômeno da leitura. Não é preciso ser um especialista em educação ou em leitura para perceber que se trata de um rebaixamento de nível, pois qualquer criança de quarta-série, mesmo sem dominar completamente a leitura, saberia identificar o título de um livro ao olhar para a sua capa (no caso, o aluno copista copiaria com os olhos o nome da obra).

\section{Texto de divulgação científica/(12) Texto de divulgação científica}

Dois textos do mesmo gênero em sequência, um abordando a função da cauda nos animais, e o outro, descrevendo o golfinho. O primeiro traz dois testes $(19,20)$ e o segundo, três $(21,22,23)$, todos cobrando localização direta de informação. Os três sobre o golfinho (p. 11) quase não necessitam do texto para serem resolvidos, pois são absolutamente autoevidentes. Perguntam se o golfinho é: 
(A) um réptil; (B) um peixe; (C) um inseto; (D) um mamífero.

A dúvida do aluno, sem ler o texto, ficaria entre a $B$ e $D$, peixe ou mamífero, mas a primeira linha do texto já resolve:

Todo mundo pensa que o golfinho é um peixe, mas não é. Ele é um mamífero.

O teste seguinte (22) pergunta o que o golfinho-comum come:

(A)folhas, $(B)$ insetos, $(C)$ peixes e lulas $(D)$ ratos e coelhos.

Também não é preciso ler o texto, visto que com base em imagens da TV (são frequentes as imagens de golfinhos comendo peixe), se pode concluir que esse bicho come peixes e lulas.

O teste 23 é também bem simplório, pois a pergunta por que 0 golfinho-comum, quando mergulha, não pode ficar embaixo da água por mais do que 8 minutos também não exige que se (re)leia o texto. $\mathrm{E}$ as alternativas apontam que ele deve subir à tona para:

(A)nadar, (B) comer, (C) brincar, (D) respirar.

Temos aí, então, dois textos mais ou menos longos na prova (os dois juntos somam 26 linhas), cujas leituras também podem ser dispensadas, favorecendo o que já é praticado nas escolas, a intepretação de texto cuja leitura - "revestrés" - vai dos testes para o texto, ou seja, primeiro se toma consciência sobre o que o teste pergunta, depois se procura com o dedo a parte onde está a resposta. ( $O$ aluno sempre deduz que, em geral, ela se encontra no primeiro parágrafo, já nas primeiras linhas), situação esta já denunciada por Geraldi: 
E é muito frequente os alunos lerem primeiro as perguntas que se seguem ao texto de leitura do livro didático para encontrarem alguma razão para o esforço que farão. Mais frequentemente ainda, como tais perguntas podem não exigir qualquer esforço, de posse delas, o aluno passeia pelo texto e sua superfície em busca das respostas que satisfarão não a si, mas a aferição de leitura que livro didático e professor podem vir a fazer" (1997, p. 170)

Parlenda: Trata-se de um texto de origem oral, Cadê o toucinho daqui?, que é interrompido para que o aluno descubra o verso que melhor complete a sequência. Como o último verso é Cadê a água? A resposta no teste só pode ser a (B) $O$ boi bebeu, pois todas as demais não teriam nada a ver com água: (A) O boi saiu, (C) $O$ boi comeu, (D) O boi morreu. Mais um texto que é incluído na prova só para "provar" que a diversidade de gênero e a oralidade infantil estão contempladas, pois do ponto de vista da leitura o teste cobra uma inferência direta e muita simples. (Mesmo que o aluno não tenha o texto na memória, a relação "bebeu" só pode ser com "água", certo?) É muito difícil cobrar textos de origem oral em prova escrita, já o vimos com a adivinha. Como veremos, em nossa perspectiva eles são fundamentais para preparar a leitura, mas não se precisa forçar a barra para torna-los itens de avaliação.

\section{Tirinha de revista em quadrinhos :}


25. Leia a tirinha e responda.
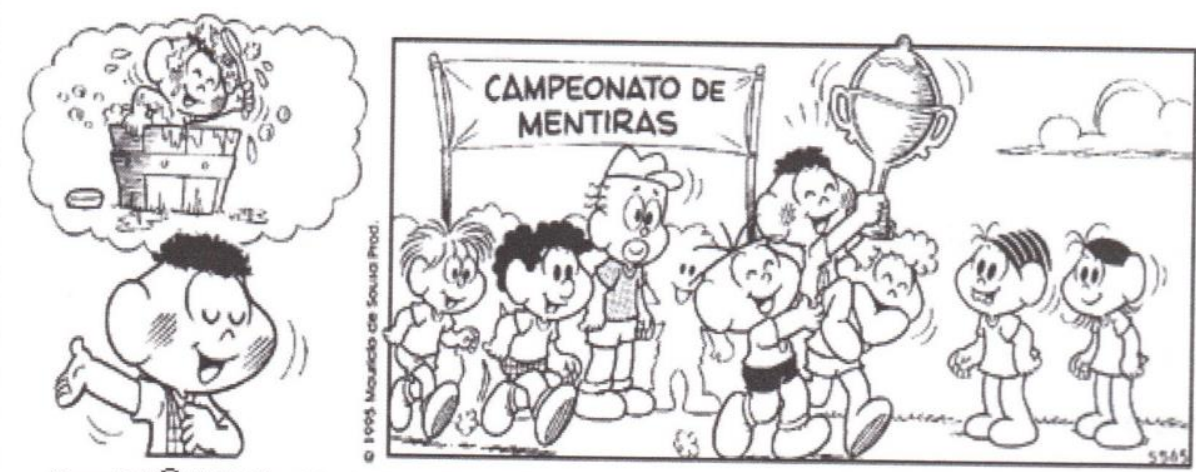

Copyright (C)1999 Mauricio de Sousa Produộes Ltda. Todos os direitos reservados.

O Cascão ganhou o concurso de mentiras porque
(A) é o campeão do futebol.
(B) comeu mais que a Magali.
(C) é o melhor amigo da Mônica.
(D) disse para os amigos que tomou banho.

Talvez esse seja o único teste da prova que realmente exige uma inferência, ainda que bastante óbvia para um leitor de revista em quadrinhos, pois mesmo que ele não percebesse a relação entre um quadrinho e outro, o contraste entre as alternativas deixa tudo claro sem grandes necessidades inferenciais.

Conto de fadas : apresenta-se um fragmento do conto de fadas $A$ princesa e a ervilha para se cobrar três testes que novamente vão solicitar informações explícitas e diretas do texto.

Fábula : utiliza-se mais uma fábula para se extrair dois testes do mesmo nível que o anterior, embora talvez possam ser considerados pelos avaliadores como outros "itens" ou habilidades. Novamente as questões redundam em inferências simplórias, a partir de elementos bem explícitos no texto. 
Texto científico: Trata-se de um texto sobre a Onça pintada, mais precisamente sobre sua alimentação, pois de suas seis linhas apenas a primeira e parte da segunda tratam de outro tema que não a sua alimentação; no entanto, estranhamente, aparece embaixo um esquema para a extração de informações a partir dos tópicos:

NOME POPULAR

NOME CIENTÍFICO

PESO ADULTO

HABITAT

As três primeiras estão explícitas no título e na primeira linha. A quarta estaria também na primeira linha, mas trata-se de um equívoco: o habitat da onça-pintada é a mata atlântica, o serrado e outras matas brasileiras e não a resposta que se espera, a América, pois este termo seria o continente ou espaço por onde se distribuem os habitats desse animal. Falta de precisão também é um atributo desta avaliação.

A avaliação se encerra com uma redação que consiste em reescrever uma fábula que alguém leria previamente para os alunos. Aliás, a fábula passou a ser o "gênero encantado" desde que se adotou a "perspectiva da diversidade de gênero": por ser de pequena extensão, ocupa pouco espaço e permite questões que facilmente se tornam "item", por exemplo, o aluno descobrir de que gênero se trata ou onde se localiza a moral da história. 


\section{SÍNTESE E REFLEXÕES SOBRE O CONJUNTO DAS AVALIAÇÕES E SEUS ESTOFOS TEÓRICOS E METODOLÓGICOS.}

Nos três modelos, Prova Brasil, SARESP e Prova da Cidade, fica evidente que as teorias estão sendo levadas ao pé da letra e que o esforço de fidelidade a elas acaba abrindo as comportas da permissividade em relação aos discursos dominadores, como o publicitário, além de favorecer a simples extração de informações explícitas do texto, como já denunciaram Geraldi (1997, p.158) e Marcuschi $(2001)^{70}$, em relação aos livros didáticos e aos manejos pedagógicos tradicionais. Outra tendência comum aos três sistemas é a banalização do texto literário, posto em jogo como se fosse um gênero útil, um "texto-pretexto", figurando em pé de igualdade com gêneros triviais do cotidiano, como a receita, a propaganda, o texto instrucional, a notícia e outros - denúncia que se encontrava em Lajolo, Zilberman e em boa parte dos autores da coletânea Leitura em Crise na Escola: As alternativas do professor (Zilberman,1988). Os textos do cotidiano, sob o pretexto de situar o universo de letramento do aluno, prevalecem sobre os gêneros literários e de opinião (textos polêmicos), que são os mais interessantes para o ensino da leitura. Os poucos testes, em geral de curta extensão, que incidem sobre os textos literários, em vez de valorizar seus elementos estéticos e sua dinâmica intersubjetiva, tratam-nos como se fossem textos informativos ou de uso cotidiano.

\section{MANUAIS DIDÁTICOS: UMA OLHADA NO PNLD}

Analisando os manuais didáticos mais bem cotados na avaliação do PNLD, pode se notar que também nesse campo se vem assumindo

\footnotetext{
70 Nesse seu artigo, Marcuschi classifica os tipos de questões dos livros didáticos em nove tipos, o primeiro, o mais simplório era CAVALO BRANCO, ou seja, perguntas do tipo "Qual era a cor do cavalo branco do Napoleão", ou seja, "autorespondidas pela própria formulação" (p.52). Boa parte das questões da PROVA SÃO PAULO enquadra-se nesse tipo.
} 
toda essa carga ideológica. Em todos eles pululam receitas de culinária, textos instrucionais (como manuais de brinquedo ou instruções para se fazer um desenho ou um objeto), passagem de ônibus, bula de remédio, logomarcas, cartazes publicitários e outros. O texto literário figura do mesmo modo que nas avaliações, distribuído a partir de certa diversidade de gênero (contos de fadas, fábulas, poesias infantis, cordel e outros), sempre perdendo em volume para os gêneros úteis. A estratégia da diversidade de gêneros é adotada de forma dispersiva, sem levar em conta que determinadas faixas etárias precisam conviver de forma mais densa e demorada com alguns gêneros, por exemplo, com os contos de encantamento. Como é a diversidade que está em jogo, distribuem-se ao longo do ano letivo todos os gêneros possíveis (quanto mais diversidade, melhor), mas sempre priorizando o texto curto, bem adaptado à lógica e ao custo do mercado editorial.

\section{O GUIA DE LIVROS DIDÁTICOS: MAIS EQUÍVOCOS}

Para demonstrar como a "diversidade", "a língua/linguagem como uso", "o universo de letramento", "os gêneros do discurso", "a construção do conhecimento" se enfeixaram num amplo consenso nas políticas dos governos, tomaremos para análise o Guia de Livros Didáticos - PNLD 2010 : Letramento e Alfabetização: Língua Portuguesa ${ }^{71}$.

Na Introdução, encontramos a justa relevância que se dá às áreas de Língua Portuguesa e Matemática e já se enuncia o objetivo central, também justo e bem adequado; no entanto, como veremos mais adiante, já se põe aí a premência de uma demanda que vai justificar toda a instrumentalização teórica e prática para que supostamente se chegue à sua consecução:

${ }^{71}$ http://www.oei.es/pdf2/guia_pnld_2010_lingua_portuguesa.pdf (última consulta: 03 de agosto de 2011) 
Nesse contexto, o letramento e a alfabetização linguística, de um lado, e a alfabetização matemática, de outro, têm se revelado como demandas nucleares, o que lhes tem conferido o papel de eixos orientadores, tanto das reorganizações curriculares para o primeiro segmento, quanto da formação docente continuada, ou mesmo de avaliações oficiais de rendimento, como a Provinha Brasil. Assim, o ensino-aprendizagem de cada um dos componentes curriculares vem sendo abordado, nas orientações oficiais, do ponto de vista de sua contribuição para a consecução do objetivo central de inserir a criança, da forma mais qualificada possível, na cultura da escrita e na organização escolar, garantindo sua plena alfabetização, tanto linguística quanto matemática, nos dois ou três primeiros anos.(p.18) (grifo nosso)

Na sequência, chama-se atenção para a centralidade dos objetivos desse ciclo inicial, realçando a importância de a criança (de seis anos) (re)conhecer as "funções sociais" da escrita e da matemática. Após apresentar os objetivos centrais de Língua Portuguesa, o documento reforça sua posição discursiva:

Assim, as práticas de uso da linguagem, isto é, as atividades de leitura e compreensão de textos, de produção escrita e de produção e compreensão oral, em situações contextualizadas de uso, devem ser prioritárias nas propostas dos livros didáticos. ( $p .18$ )

Não é difícil concordar com essas divisas, pois de fato é o mundo vivo da linguagem que conta, mas não seria fundamental compreender o que seria uso da linguagem ou as tais situações contextualizadas de uso quando se pensa em uma criança de seis ou sete anos? Se tomarmos o cotidiano de uma criança urbana (talvez até mesmo rural, pois hoje as mídias conseguem programações onipresentes), o que vamos encontrar? As crianças assistem à TV, estão constantemente em contato com produtos do mercado e 
submetidas a seus apelos publicitários (brinquedos, doces, comidas, roupas etc.), um certo percentual (seria interessante saber qual) conta com conversas com os pais, nas quais podem se incluir atividades lúdicas, histórias e outros gêneros (também seria importante saber quais gêneros e textos prevalecem). Já se tornou corrente dizer que o universo de letramento de uma criança urbana é amplo, rico, diverso. Tudo isso parece indicar uma lógica meio direta: cabe à escola simplesmente trazer e intensificar esse "uso da linguagem" (esse "universo de letramento", esses gêneros e situações discursivas que estão presentes no cotidiano das crianças). É o que, sem grandes dissensões, vão fazer os manuais didáticos, ou seja, encadear ao longo dos anos essa diversidade para que a criança reconheça as funções sociais da escrita e se sinta verdadeiramente incluída. Aliás, esse amplo consenso é quase comemorado pelos autores do Guia:

Já se pode perceber nitidamente, no conjunto das coleções, uma incorporação maior dos objetivos e das perspectivas introduzidas pela virada pragmática no ensino de língua materna, tais como aparecem nos PCN da área e nos próprios princípios e critérios de avaliação propostos pelo PNLD (p. 27)

A virada pragmática é explicitada no rodapé da página. Como venho tentando mostrar, parece haver uma ânsia e até certo medo dos educadores e teóricos de se parecerem ou demonstrarem afinidades com as "coisas do passado" (da ditadura?); nesse sentido, convém mostrar o que se entende por esta virada:

A expressão "virada pragmática" tem sido empregada para caracterizar um conjunto de mudanças que, desde a década de 1980, vêm ocorrendo na pesquisa acadêmica, na concepção do que deve ser o ensino da língua portuguesa. Muito resumidamente, mudou, de um lado, a concepção do que seja ensinar, sob o impacto das pesquisas em aprendizagem e, em 
especial, em aquisição da escrita; como já é possível entender como se aprende, as concepções, os métodos $e$ as técnicas estabelecidas de ensino vêm sendo inteiramente revistas, com o objetivo de ajustar-se ao movimento próprio da aprendizagem. Por outro lado, mudou, também, a concepção de linguagem, com a incorporação progressiva de investigações mais recentes sobre a língua em uso (discurso) e sobre os procedimentos e mecanismos envolvidos na construção do texto (rodapé da página 27).

Mais adiante, o documento mostrará que as coleções aprovadas para as séries iniciais estão todas dentro da "linha" e faz questão de mostrar a diferença entre estas e as de "15 ou 20 anos atrás", frisando que os textos apresentados são autênticos e não pseudotextos. Realçam também que todas elas assumem a perspectiva do "gênero", ou seja, assumem o gênero como "unidade básica" e, muitas vezes, o tomam como "objeto de estudo".

As dezenove coleções aprovadas apresentam, então, essa notável afinação teórica e metodológica. Em todas elas se encontram os gêneros do cotidiano: receita, cardápio, logomarca, cartaz, bilhete, carta, convite, texto instrucional, notícia, reportagem, placa e outros. Semeados entre eles, poemas, contos, fábulas, parlendas, adivinha e outros da cultura popular e da literatura.

Como não é possível analisar todos os livros didáticos, vamos nos ocupar apenas de três deles, os que encontramos nas escolas e cidades onde se processa nossa pesquisa em rede:

1. Belém - PA : Manual Didático enviado ; "L.E.R: ESCRITA E REFLEXÃO" - 10. Ano" Editora FTD, (PNLD 2010, 2011,2012)

Na análise do PNLD, a resenha desse manual está entre as páginas 81 e 85 e sua tipologia textual assim é apresentada:

10. Ano: lista, ficha informativa, instrução de jogo, história (produção, reprodução, modificação final). 
A análise do volume do primeiro ano mostra que essa tipologia feita pelos que analisaram o livro é bem parcial, pois encontramos muitos outros textos (parlendas, trava-línguas, cantigas, música infantil, textos informativos e outros), mas o que morre à míngua mesmo é a literatura, seja oral ou escrita. Fiel ao projeto de inserir o aluno nas condições de letramento e partir da ideia de que língua/linguagem é uso prosaico, a página inicial abre um cenário de cidade, com placas de ruas e publicidades, além de um homem lendo jornal. A cena sintetiza a preocupação do livro, pois esta será a toada até a última página.

O módulo I traz atividades, a partir de uma ideia de biografia/identificação da criança, que se concentram no objetivo de conhecer as letras e correlacionar a palavra escrita com sua imagem. Apenas dois textos de autoria acompanham essas 55 páginas: uma letra de música e o texto Gato de Ricardo Azevedo com marcas de supressão de trecho. Esses tipos de atividade, por exemplo, atividades com letras e com os nomes dos amigos da classe, das professoras da escola em questão, em geral, os professores fazem sem necessidade de manuais.

O módulo II traz gêneros para se brincar com o "som" das palavras (p. 57) - talvez seja o módulo mais interessante do livro, o único que de fato contempla uma relação interessante entre textos do universo da criança e atividade de alfabetização (por exemplo, exploração de rimas em parlendas).

O módulo III apresenta o texto instrucional, texto que ensina a fazer coisas, entre elas a famigerada receita. Há mais texto instrucional no livro do que poesia.

O módulo IV se ocupa do texto informativo, com suas fichas de características de animais. São muito semelhantes às que estão na Prova Brasil e em outras avaliações (SARESP, Prova da Cidade) prevalece a descrição do animal e suas características. 
O módulo $\mathrm{V}$ traz três histórias, A princesa e a ervilha, Os três porquinhos, e uma de autoria, $O$ velório da onça (Pedro Bandeira).

Levando em conta que este livro se destina a crianças de seis anos, de uma escola da periferia de Belém, já temos aí uma significativa discrepância. O imaginário da Amazônia sequer aparece no livro, talvez um texto que poderia resvalar levemente seria a história da onça, em $\mathrm{O}$ velório da onça. Além da quantidade insuficiente de textos, o conjunto de narrativas do livro não tem a missão de encantar, de pôr a criança na narrativa e diante de um imaginário interessante. Se lembrarmos que o folclore amazônico permitem narrativas instigantes (As lendas do Guaraná, do Açaí, da Mandioca, do Uirapuru, ou mitos bem interessantes como 0 Mapinguari, a Matinta Pereira, Cobra Norato, Boto e tantos outros), fica muito claro que o livro distancia a criança de seu imaginário regional. Talvez até seja por isso que apostar no texto instrucional, na receita, na propaganda, seja interessante para as editoras e para os autores, pois assim é possível contemplar o "uso da língua" de uma forma mais generalizada, sem ter que fazer concessão à regionalidade - afinal, um universo de letramento sem singularidades não precisa ter cuidados sutis com as regionalidades, bastando apresentar aqui e ali alguns exemplos de "respeito à língua popular", para assim contemplar mais um item desses compromissos: a variação regional.

Consultando abaixo a lista de gêneros do segundo ano, pode-se notar que a diversidade e a dispersão são ainda mais amplas:

20. Ano: fotografia, história em quadrinhos, canção, certidão de nascimento, quadrinha, poema, biografia, conto, diário, acróstico, bilhete, receita culinária, trova, aquarela, reportagem, entrevista, artigo de divulgação científica, adivinha, conto de fadas, $1^{a}$. capa de jornal, capa de DVD. 
2. São Paulo - Escola de Aplicação da FE-USP: PENSAR E VIVER : LETRAMENTO E ALFABETIZAÇÃO LINGUÍSTICA. Editora Ática, 2010 (PNLD 2010, 2011, 2012)

O livro apresenta 240 páginas e um encarte com alfabeto e sílabas recortáveis. Em linhas gerais, traz um conteúdo superior aos enviado à escola de Belém, mas a escolha dos textos é igualmente guiada pela ideia de diversidade de gêneros. Recobre desde os gêneros prosaicos do cotidiano (logomarcas, rótulos, embalagens, propagandas, bilhetes, etiquetas, textos instrucionais e outros) a textos de autoria e da tradição oral infantil (embora veiculados como material da escrita). Apresenta no final do volume uma coletânea de textos como leitura suplementar e uma espécie de síntese dos capítulos na forma de lição de casa.

Como todo manual didático, também procura recobrir o trabalho do professor, apresentando desde o trabalho com o nome do aluno (neste manual é extenso e redundante, ocupando muitas páginas) a abordagens de temas bem atuais, como por exemplo o bullying, que norteia, por exemplo, a escolha do texto Ninguém é de Ninguém (p. 56-57), para tematizar os apelidos que são dados para caracterizar diferenças. Há uma grande quantidade de tirinhas e de excertos de quadrinhos, por exemplo, da turma da Mônica. Boa parte das atividades de leitura, seja de quadrinhos ou de textos literários, fica no entorno do texto (autor, personagem, capa de livro, balão de quadrinho etc.), ou seja, não produzem leitura.

Em relação à introdução do neoliberalismo na escola, não fica atrás dos demais: apresenta propagandas e logomarcas (logo no início, já encontramos, na página 16, Fiat, Açúcar União, Unibanco, Nestlé, Pepsi. Mais adiante, apresenta propaganda direta de docinhos: Goiabinha, Triunfo, Bauducco, p. 86), pesquisas com embalagens (p. 62). Difere do outro por uma heresia um pouco maior: na página 159 as personagens da turma do Sítio (Monteiro 
Lobato) são veiculadas na embalagem do sabão em pó OMO. Ao abordar a propaganda, uma das questões até tenta alertar a criança (de seis anos!) para o efeito da publicidade, mas o que prevalece, em volume e sedução, é a propaganda em si. Os autores chegam a destacar em um box colorido que

A TURMA DO SÍTIO DO PICA PAU AMARELO ESTÁ
ESPERANDO PARA BRINCAR COM VOCÊ. TEM A EMÍLIA,
O VISCONDE, A CUCA, O SACI E O RABICÓ PARA VOCÊ
COLECIONAR. E TEM AINDA UM CENÁRIO BEM LEGAL
PARA VOCÉ MONTAR. PEÇA JÁ PARA SUA MÃE. ELA VAI
ADORAR A BRINCADEIRA (p. 160)

A questão $\boldsymbol{d}$, que tenta alertar sobre o efeito da publicidade, está ali apenas para driblar as normas do PNLD, que proíbe propagandas nos manuais didáticos, embora os próprios autores e editoras saibam que essa proibição figura nas normas para ser driblada, como um zagueiro bobo em campo.

Em relação aos gêneros oriundos da tradição oral, o conhecimento dos autores é precaríssimo. Há apenas dois contos populares brasileiros, mas adaptados para a escrita, embora haja alguns textos que são da oralidade, mas que foram apropriados por autores; por exemplo: a historinha de Maurício de Sousa (p. 172), Chico Bento em Santo Antonio e o Bode (trata-se de uma história popular brasileira), ou ainda o conto VAIEVEM VAI? (p. 188), também uma historinha popular da qual a autora se apropriou. A diferença entre oralidade e escrita, confortavelmente para as autoras, não existe; tudo é veiculado pela escrita e pertence ao mundo dela.

Se levarmos em conta a heterogeneidade que há nas duas salas de primeiro ano da EA-FEUSP, as singularidades do espaço escolar (a escola tem uma grande biblioteca, biblioteca de classe com livros e revistinhas à vontade, silabários e alfabetos móveis, coletâneas próprias de textos orais, duas salas de computadores, projetores multimídias; todas as crianças possuem o laptop do projeto UCA) e que boa parte dos trabalhos apresentados no início do livro já foi 
posta em jogo pelas escolas infantis, de fato não é difícil aos professores justificarem a recusa do livro (os exemplares ficam empilhados em um armário da sala, mas não são utilizados), pois o que fazem (mesmo ainda não tendo um vasto conhecimento das técnicas e repertórios da tradição oral) é muito superior ao que o livro apresenta.

1. PAU DOS FERROS (Sertão do Rio Grande do Norte): -INFÂNCIA FELIZ : LETRAMENTO E ALFABETIZAÇÃO LINGUÍSTICA. Editora Escala Educacional

Dos três manuais analisados, o Infância Feliz é o que mais propõe atividades oriundas da cultura oral. Não enfatiza tanto os textos úteis do cotidiano (receitas, textos instrucionais), ou seja, não assume ao pé da letra a palavra de ordem dos usos da língua e do universo de letramento do cotidiano. Quase todas as atividades partem de brincadeiras encetadas a partir de performances e que, ao mesmo tempo, valorizam os elementos estéticos dos textos escolhidos. Mesmo os poucos textos instrucionais estão voltados para o jogo, para a brincadeira. Traz também alguns projetos interessantes, que levam as crianças a pesquisar brincadeiras de antigamente, histórias, cantigas, animais (e as canções que falam de animais). Seu "Hora da História" reúne alguns contos brasileiros, embora ainda prevaleça o conto europeu.

Mesmo tendo apontado essas qualidades, insistimos ainda que, se levarmos em conta que foi remetido para classes de crianças sertanejas (Pau dos Ferros-RN, centro do sertão nordestino), ainda pode ser considerado um genérico como os demais. Há poucos elementos no livro que evoquem a paisagem, o homem e 0 imaginário desta cidade ou mesmo da região: não há menções a cisterna, açude, frutas da caatinga, vaqueiro, cordel, forró, histórias de Trancoso, cantadores e, muito menos, histórias e mitos do folclore 
regional ${ }^{72}$. Tomemos um gênero como exemplo: as tirinhas e histórias em quadrinhos são do SUDESTE e, como em quase todos os didáticos, prevalece a Turma da Mônica, de Maurício de Sousa. Essa centralidade de alguns autores de quadrinhos acaba impedindo que produções regionais bem significativas, como a do baiano Antônio Cedraz, tenham vez. Mostro abaixo uma tirinha deste autor, cujas revistinhas são publicadas pela mesma editora do Infância Feliz (A Escala), apenas para ilustrar que há mais do que Sudeste no mundo dos quadrinhos:

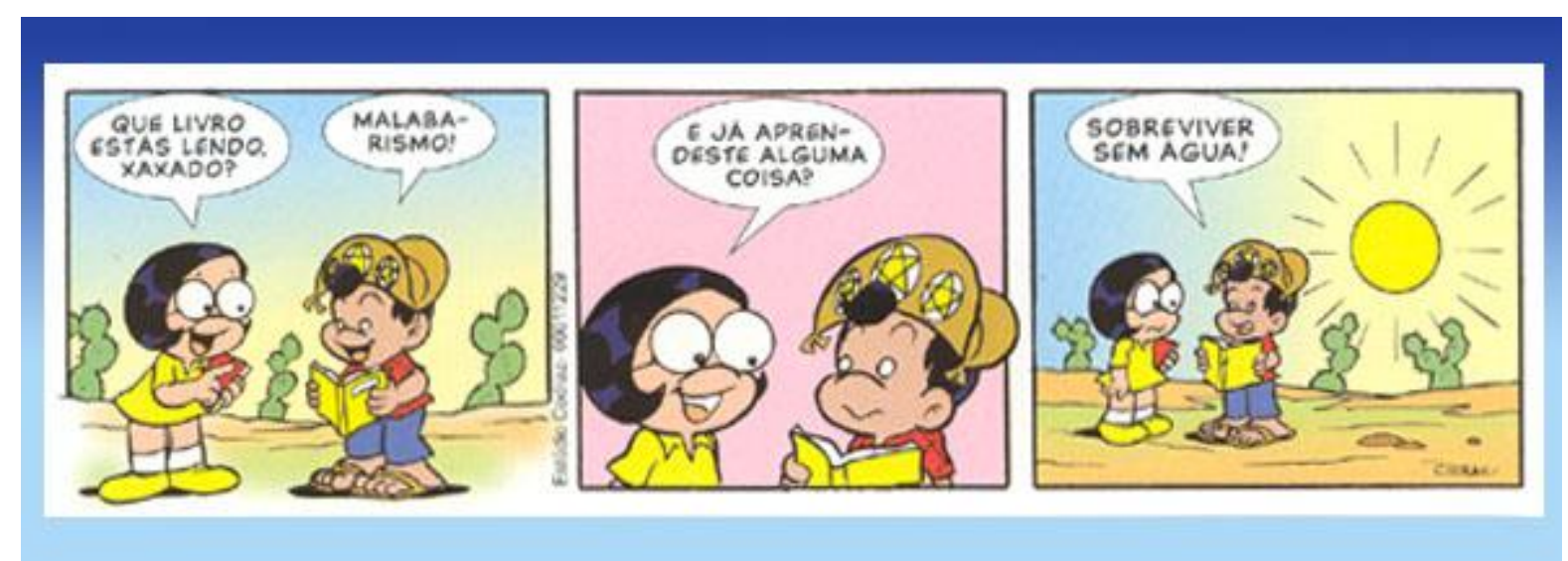

Turma do Xaxado - Antonio Cedraz

\section{CONCLUSÃO GERAL SOBRE A ANÁLISE DOS TRÊS LIVROS}

Em nenhuma das localidades o livro é utilizado pelos professores a partir do que propõem seus autores. Nas três escolas as imagens e temas ou se distanciam das reais necessidades da sala de aula ou do imaginário local. Boa parte das questões relacionadas a atividades de alfabetização - que, em geral, significam um grande volume de páginas desses livros - pode ser realizada com tranquilidade pelos professores, a partir de materiais confeccionados por eles mesmos: crachás para portar os nomes; trabalho com a

\footnotetext{
${ }^{72} \mathrm{O}$ professor do Rio Grande do Norte pode encontrar com facilidade uma coletânea, como, por exemplo, a que está no site do próprio governo do RN:

http://www.educacao.rn.gov.br/contentproducao/aplicacao/govrn/rio_grande_do_norte/gerados/cultura fo lclore.asp (consultado em agosto de 2011). E se isso for pouco (e, é!), é só relembrar que Câmara Cascudo é Potiguar e andou pelo sertão.
} 
correlação letra-imagem (quase sempre, nos livros o trabalho é feito com a primeira letra e não com a sílaba); uso de textos do cotidiano (rótulos, embalagens, receitas, bilhetes e outros); alfabetário (normalmente os professores fazem letras bastão e cursiva em folhas de sulfite e as dependuram no espaço acima do quadro negro). Talvez seja por isso que em duas escolas o uso é muito parcial e que em uma delas (São Paulo) o livro nem é utilizado ${ }^{73}$.

Em nossa atuação nas três escolas percebemos com clareza que, se em vez de um livro didático, a escola recebesse uma coletânea de gêneros oriundos da cultura popular local; se estes fossem correlacionados a manifestações culturais de outras regiões e até mesmo ampliados em outras coletâneas mais universais, como por exemplo a mitologia grega, ou os contos europeus desconhecidos (não os veiculados pelo mundo Disney), sua adoção favoreceria mais a criança e o seu meio familiar, pois no mínimo suas imagens e textos com alguma familiaridade despertariam possibilidades de expansões e enriquecimentos da cultura popular local.

A não utilização do livro ou seu uso parcial por parte dos professores talvez se efetive por três razões: (1) a pretensão que os manuais ostentam em recobrir as atividades práticas do professor e mediar demais sua relação com a classe (fazer crachá, explorar o nome próprio, definir projetos, ditar a atividade etc.); (2) a tentativa de recobrir o universo de letramento do aluno a partir de uma escolha de textos supostamente do cotidiano da criança; (3) as consignas montadas a partir de interações simuladas (para cumprir as metas do interacionismo?) artificializam ainda mais a relação professor-aluno, pois se boa parte das crianças ainda não lê, o professor teria que emprestar sua voz ao livro. Para se ter uma ideia,

\footnotetext{
${ }^{73} \mathrm{O}$ livro também não foi utilizado na ESCOLA ESTADUAL KEIZO ISHIRARA, que recebeu o mesmo manual que a Escola de Aplicação da USP, e onde se deu nossa pesquisa de 2007/2009. Esse fato está mencionado em nosso artigo, Belintane, 2010b.
} 
vejamos o início do capítulo I do Infância Feliz e imaginemos o professor em sala de aula fazendo a voz do livro:

COMO É BOM BRINCAR DE BOLA, DE BONECA, DE CARRINHO, DE CORDA! MAS, BRINCAR COM OS AMIGOS É MELHOR AINDA!

OBSERVE A HISTÓRIA ABAIXO, CONVERSE COM SEUS COLEGAS E RESPONDA ORALMENTE:

- VOCÊ CONHECE ESSA BRINCADEIRA?

- VOCÊ JÁ BRINCOU DESSE JOGO? (p.10)

(seguem-se quadrinhos de Eva Furnari, que mostram, apenas com imagens, crianças brincando de cabra-cega)

Sabemos que o custo baixo dessas autorias e o lucro que o PNLD tem representado para as editoras também entram nas justificativas que levam à manutenção do formato desses manuais; mas está mais do que na hora de repensar a proposta, talvez buscando formatos que consigam estabelecer uma ponte mais clara entre a cultura regional e outras, de abrangências e historicidade mais amplas, ampliando talvez a cultura do próprio professor. Os recursos atuais, computadores em rede e rotativas que conseguem imprimir a partir de matrizes diferenciadas, apontam para um futuro em que se pode produzir material verdadeiramente contextualizado, seja no suporte gráfico, seja no eletrônico. 
PARTE II : ALGUNS PONTOS DE NOSSA METODOLOGIA DE ENSINO DE LÍNGUA PORTUGUESA E DE ALFABETIZAÇÃO

O maior apetite do homem é desejar ser. Se os olhos veem com amor o que não é, tem ser (Pe. Vieira, em Paixões Humanas) ${ }^{74}$

Como boa parte das teorias que sustentam a concepção vigente nos governos vem de abordagens sociais e discursivas, em que parece predominar a herança marxista, que põe em relevo as "condições concretas de produção" e uma "consciência de classe"75, indagar e refletir sobre ideais, fantasias, distanciamentos da realidade concreta e palpável do cotidiano pode ser considerado "fuga da realidade" do aluno, como já o foi no passado, quando se acusava o excesso de literatura e se propugnava por mais realidade na sala de aula. O que é relevante hoje é o texto dito "real", "autêntico", que está ali diante dos olhos na convivência diária, desde o rótulo do pacote de salgadinho ou da lata de farinha láctea da Nestlé, aos escandalosos M de McDonald's e S de Sadia sassaricando diante da criança. Com a Internet, as influências se propagam e se desvirtuam com muito mais rapidez e facilidade.

Há hoje muitos sites e blogs de professoras alfabetizadoras que privilegiam os gêneros do mercado para alfabetizar. A logomarca entra como um recurso imprescindível, pois é uma escrita onipresente, cheia de um charme assimilado por uma permissividade intelectual já há muito tempo. O poema de Drummond (1992 p. 1018), Eu Etiqueta, talvez seja um grito importante contra a fixação da "letra com dono" no corpo da gente.

\footnotetext{
${ }^{74}$ Retiramos esse fragmento do "Livro sobre nada" de Manoel de Barros (Barros, 2010. p. 337).

${ }^{75}$ Embora essa influência seja clara, atualmente pouco se fala em consciência de classe como prefeririam os marxistas. Fala-se hoje em cidadania, consciência cidadã.
} 
Vejamos abaixo um exemplo de alfabetização a partir de logomarcas na Internet:

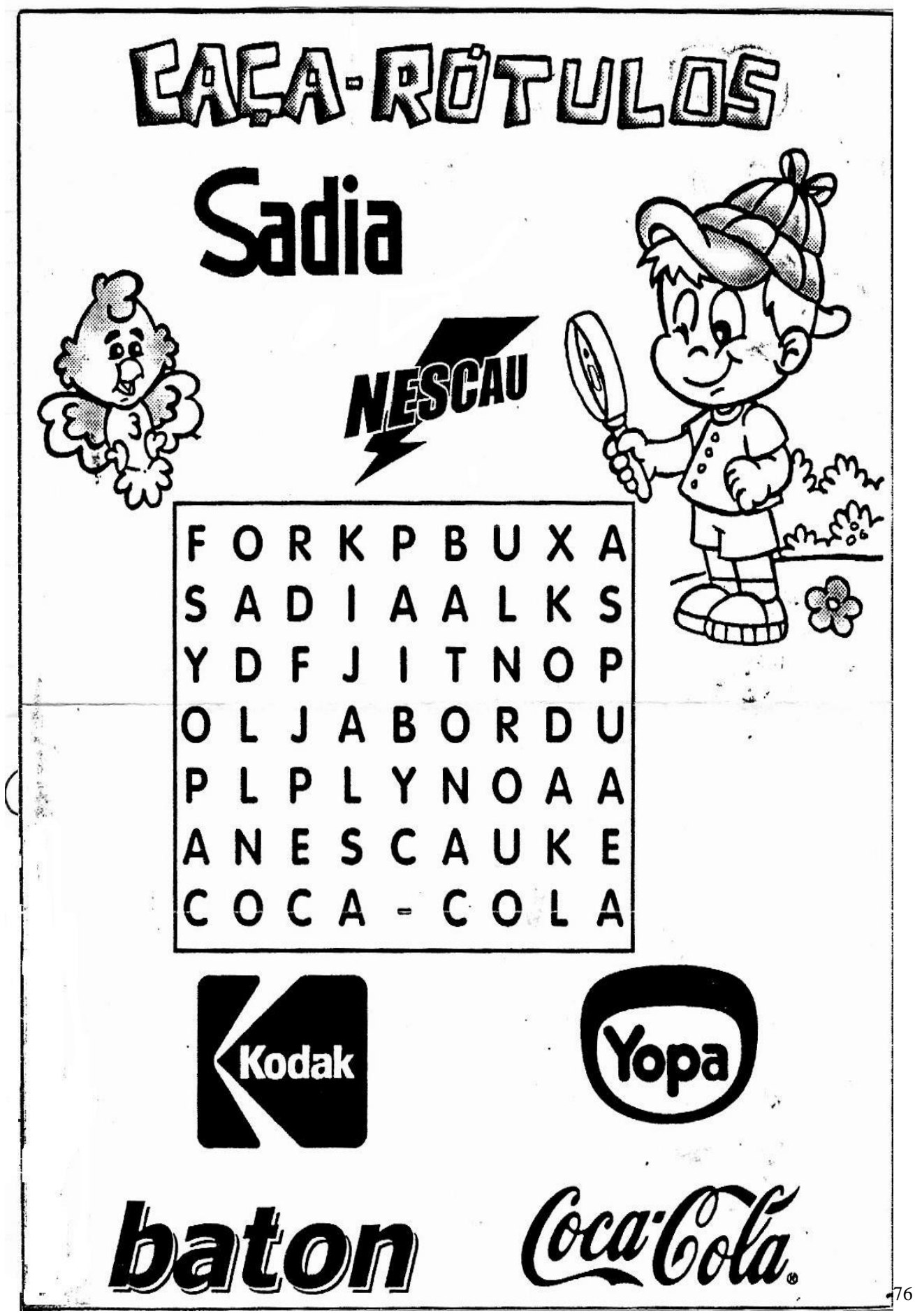

\footnotetext{
${ }^{76}$ http://cantinhodosaber11.zip.net/ (a autora do Blog, Tia Andreia, faz questão de referenciar que a maioria das atividades foram retiradas do livro "Linhas e Entrelinhas", da Editora Positivo).
} 
Esse mundo concreto de se pegar com a mão, por mais que se ofereça aos olhos e ouvidos da criança e se insinue como universo de letramento do aluno, não se compara ao que de fato põe para ela uma demanda diferenciada, do tipo "decifra-me ou devoro-te". Este universo é, ao contrário, o das coisas que não se deixam ver com facilidade. Nesse sentido, nossa perspectiva parte de um princípio, tão caro à literatura e à psicanálise, que é a ideia de falta, que Manoel de Barros traduz tão bem em versos como este, "Tem mais presença em mim o que me falta"77.

O muito próximo, ou "universo de letramento", trocaremos, sem cerimônias, por "mais distância". O concreto, ou a linguagem autêntica, trocaremos pelo abstrato, pela linguagem inventada. Assumiremos com rigor que o assunto mestre de um profissional da linguagem é a literatura, ainda que pese sobre essa escolha toda a crítica que a nova escola e as concepções vigentes fizeram ao beletrismo do passado. Tentaremos mostrar que nela é possível encontrar tudo o de que se necessita, não só para expandir a competência leitora desde a mais tenra infância, mas também para encarar as novidades do mundo contemporâneo a partir de uma nomeação desafiadora.

\section{RETOMANDO NOSSA PERSPECTIVA: O ENTUSIASMO DE UMA ORALIDADE QUE FAZ LER E ESCREVER}

Como tentamos mostrar no capítulo I, a perspectiva de ensino de leitura e escrita que estamos elaborando diferencia, mas não dicotomiza oralidade-escrita, fala cotidiana-oralidade (função comunicativa-função poética) e nem assume a ideia de um sujeito construtivista ou neomarxista-liberal de prontidão diante de quaisquer textos, gêneros ou discurso de seu meio. Diferentemente,

\footnotetext{
${ }^{77}$ Livro sobre nada (Barros, 2010. p. 345).
} 
quando sondamos ou diagnosticamos a leitura a partir da oralidade, levamos em conta que, no domínio de textos orais, já se encontram as principais habilidades de leitura, e que muitas delas não figuram como um conhecimento que se extraia com facilidade. A trama de textos orais e os interjogos linguageiros que resultam em boa leitura não são produto de uma construção consciente - como vimos no capítulo II, resultam dos efeitos da própria alíngua, efeitos metafóricos e metonímicos. Ou seja, contrariando Bronckart (1999), não conseguiríamos nos livrar de uma perspectiva "solipsista" como ele facilmente se livra no capítulo I dessa sua obra, pois o que não é tão concreto, material e palpável é o que mais nos interessa. Como mostraremos a seguir, nosso "letramento", como o defendido por Tfouni (2001), comporta o oral e, essencialmente, os gêneros que privilegiam a função poética. Em vez de levar à criança uma cidadania e uma consciência adultas, privilegiamos o desejo e a fantasia como forma de abrir portas para a cidadania do mundo, que em vez de comportar a língua e a linguagem do cotidiano imediato (que, na maioria das vezes, são marcadas pelo mercado), potencializa encontros entre o regional e o universal.

Para ilustrar e tornar mais clara nossa posição diante das linhas consensuais que influenciam o ensino da linguagem em nosso tempo, retomaremos aqui uma velha polêmica já aludida nos capítulos I e II, a questão do útil $x$ o desútil, ou seja, a posição da função poética e da literatura diante da função comunicativa/pragmática dos textos oriundos do universo de letramento imediato da criança (gêneros do cotidiano).

Ortega y Gasset, já em 1920, vislumbrava um letramento outro - muito mais para a função poética do que para a subjetividade cidadã do ensino de hoje. Em seu brilhante artigo El Quijote en la Escuela (1993), o filósofo espanhol contesta o pragmatismo que já vinha se esboçando no campo da educação. Seu texto dialoga com um artigo de jornal escrito por Antonio Zozaya, que criticava a 
adoção de Dom Quixote em todas as escolas primárias da Espanha (essa era uma imposição da Real Ordem Espanhola). Para Zozaya, em vez de literatura, a escola deveria se ocupar de certas técnicas e leituras que preparariam para a vida (tudo a ver com o que hoje se apregoa, a preparação para o exercício da cidadania), daí que sugeria, portanto, a leitura de periódicos.

O filósofo contraria o escritor-jornalista e sua pedagogía practicista, mostrando que o jornal e as revistas se ocupam da superficialidade da vida e que mesmo a curiosidade em torno da tecnologia - o que é ou como é um trem de ferro, uma fábrica ou letra de câmbio, referências aludidas por Zozaya (p. 12) - não toca na dimensão mais profunda que motiva a criança a aprender, a descobrir. Discutindo a questão a partir da ideia do que seria mais vital para o psiquismo da criança, Ortega mostra que o fundamental não é educar para a vida, mas sim para uma vida criativa, para uma vida em que prevaleçam a arte, o mito, a literatura e os esportes. Apesar de o artigo trazer fortes influências da biologia da época e até mesmo do Übermensch de Nietzsche, seu toque principal é o combate ao pragmatismo, a uma educação que, em vez de aproveitar a pujança do desejo infantil e suas possibilidades de expansão mítica e imaginativa, poda-Ihe seus brotos mais promissores, bonsaizando-os precocemente para adaptá-los a um meio adultocêntrico, ou como poeticamente expressa o filósofo, atua contra la niñez del niño, a reducir quanto puede su puerilidade, introduciendo en él la mayor cantidad posible de hombre. (p. 32). Impressiona como essa crítica do filósofo poderia ser reaplicada hoje, mesmo incluindo o desenvolvimentismo vigotskiano:

[...] es la madurez una integración de la infância. Todo el que tenga fino oído psicológico habrá notado que su personalidade adulta forma uma sólida coraza hecha de buen sentido, de previón y cálculo, de enérgica voluntad, dentro de la cual se agita, incansable y prisioneiro, um niño audaz. [...] Así, el canto del poeta y la palavra del sábio, la ambición 
del politico y el gesto del guerrero son siempre ecos adultos de un incorregible niño prisioneiro ( $p .33$ )

O mito, a lenda, as narrativas que tocam nas origens, que enfrentam o mistério da morte e da ressurreição (como a lenda brasileira do "guaraná" ou a história da "Bela Adormecida") também, de alguma forma, são efeitos da função poética e das matrizes primevas e fundamentais da literatura. A magia, por exemplo, que faz nascer de um corpo humano enterrado (de uma menina) um pé de vegetal que vai matar a fome de um povo, não deixa de ser um deslocamento dos elementos da realidade que em geral são recobertos pela função referencial da linguagem: o corpo simplesmente apodreceria na terra sob o festim dos vermes juntamente com ele, não fossem essas possibilidades de expansão mítica, apodreceria também a vitalidade da linguagem e do psiquismo infantil. Do mesmo modo, quando a criança bordeja o nonsense, abrindo a linguagem ao mistério, ao estranhamento, está também revitalizando seu psiquismo, suas possibilidades de releitura, tanto da vida como da palavra. Por outro lado, se sua infância se concentra em uma linguagem unívoca, instrumentalizada pelo uso cotidiano dos adultos, muito provavelmente seu desejo de ler, de enfrentar destemidamente textos longos e misteriosos ficará embotado, sempre preso à correlação direta entre significante e significado, ou entre linguagem e o mundo prosaico. Mais grave ainda é a criança não poder desfrutar da emoção estética da poesia, dos efeitos de sentido que emanam desse redobramento da mensagem sobre si mesma, como os que Jakobson (1995) brilhantemente analisa na poesia "O Corvo", de Edgard Alan Poe; emoção que não deixa de ser o motor psíquico de toda criança, seja ela o aluninho que tenta se alfabetizar, seja o cientista que reabre seu espaço de autoria a partir de seus delírios e fantasias sobre a vida e a morte.

É muito difícil encontrar uma criança que não aprecie esse redobramento, mesmo nas piores condições da vida - por exemplo, 
em uma favela da zona Oeste da cidade de São Paulo, onde desenvolvíamos um projeto pedagógico, eu costumava cumprimentar as crianças e até mesmo os adolescentes com uma fórmula inspirada nas apresentações do palhaço Arrelia ${ }^{78}$ (aqui ligeiramente modificada):

- Como vai, vai bem?

Vai a pé ou vai de trem?!

O efeito era sempre positivo desde os primeiros contatos. Não raro, as próprias crianças vinham ao meu encontro me cumprimentar repetidamente só pelo prazer de brincar com a fórmula rimada. Até mesmo aquelas de catorze, quinze anos - que tanto nos assustam nos faróis - vinham sorrindo brincar com as palavras. Algumas imediatamente entravam no faz de conta e respondiam: "hoje eu vou de avião!" "...de navio", "...de bicicleta", enfim, iam variando suas possibilidades de seleção, mas o mais gostoso era perceber que elas curtiam essa ambiguidade da forma verbal "vai" (ir bem de saúde, na vida, e "ir" no sentido da locomoção - essa ambiguidade rompe com a seriedade da polidez adulta).

É interessante frisar que de fato há um envoltório de letramento na favela, nas periferias (propagandas da Kibon, da Hello Kit, do McDonald's, da Sadia, do Itaú chegam a essas crianças de forma até excessiva), pois há uma infinidade de cartazes nos bares e padarias, assim como há revistas e DVDs que circulam gratuitamente a baixíssimo custo. Mas nada disso resulta em leitura, em algum tipo de envolvimento mais denso com a escrita; ao contrário, parecem suscitar uma leitura iconográfica, apressada, que extrai os seus sentidos dos elementos mais periféricos ao texto (tamanho do

\footnotetext{
78 Arrelia cumprimentava com o seu famoso, "Como vai, como vai, vai-vai?", a criança tinha que fazer o paralelismo: "Eu vou bem, muito bem, bem-bem!" Até hoje esse sino que bate alegre na voz do velho palhaço e da criança traz um encanto maravilhoso. Lembra bem o poema de Manuel Bandeira, "Os Sinos", pois os "Sinos de Belém/Batem bem bem bem!".
} 
portador, local onde está afixado, imagem etc.) - como vimos, as avaliações, materiais didáticos e programas dos governos redundam suas estratégias também nesses aspectos exteriores ao texto em si. No afã de cumprir a meta ideológica que apregoa o social, o uso da linguagem, o gênero, o letramento etc., esses intelectuais esquecem que a criança, sobretudo a criança pobre, precisa muito de encontros constantes com a fantasia, com o mítico, com o que extrapola a realidade palpável. Pois é dali que ela poderá reunir forças, vitalidade psíquica, para fazer da escrita uma ferramenta que a faça capaz não só de ler denotativamente a realidade que a cerca, mas também de imprimir a ela o desejo de transformá-la, ainda que inicialmente esse desejo seja fantasioso. É bem verdade que o chamariz dos textos publicitários, dos rótulos e artifícios marqueteiros se vale da função poética e pode atrair a criança, contudo não é preciso introduzi-los como lição nas salas de aula de crianças de seis a dez anos - se elas aprendem a ler com a pujança dos textos literários, com a nutrição substanciosa dos mitos e lendas, com o puxa-puxa do conto de aventura que faz uma criança de sete anos ler "O Saci" de Monteiro Lobato79, certamente saberão ler os textos do cotidiano e estarão preparadas para desconstruí-los na idade certa.

Em vários $\operatorname{artigos}^{80}$ venho chamando a atenção para a importância da narrativa e dos gêneros de origem oral em que prevalece a função poética da linguagem. Insisto que esse estofo linguageiro é fundamental para uma alfabetização dinâmica porque constitui as matrizes textuais que estabilizam e fornecem o fluxo, 0 ritmo, a dicção, dando corpo a uma leitura significativa e de maior

79 Como mostramos em Belintane (2010), durante a execução de nosso projeto, conseguimos ler o Saci de Lobato com uma classe de primeiro ano, utilizando a estratégia da contação de história em primeiro plano, retomando com vigor a figura lendária do Saci. Em seguida, iniciamos a leitura do livro, mas intercalando leitura e contação de forma bem estratégica. Nos momentos mais catárticos, deixávamos a leitura por conta deles, que embalados pela curiosidade, pelo entusiasmo da aventura e dos mistérios que os personagens e seres lendários punham em jogo, conseguiam em grupo terminar o trecho posto como desafio. No capítulo IV, vamos discutir com mais detalhes os resultados desse projeto.

${ }^{80}$ Belintane (2005, 2006a, 2006b, 2008, 2010) 
envergadura. Diferentemente dos textos oriundos da fala e do cotidiano, os de origem oral, como a leitura, exigem rituais de apropriação, momentos de parada do corpo - aliás, uma boa contação de história ou uma oficina de ludismos orais são mais que ritalinas no combate ao TDAH ${ }^{81}$-, lidas específicas com o ato de narrar, de declamar ou mesmo de usar a linguagem fora da dimensão pragmática da fala.

A fala, os gêneros, textos e discursos que banham o cotidiano da criança constituem de fato dimensões importantes da língua e da linguagem, mas não possuem o mesmo relevo e poder que os textos oriundos da tradição oral e os literários exercem sobre o imaginário infantil. Não é por acaso que a propaganda e o marketing se valem da função poética e das artes em geral e que os homens, desde as civilizações da Mesopotâmia, lançavam e lançam mão de provérbios, alegorias, fábulas e poemas para aconselhar ou ensinar os valores da vida. Não são ocasionais os sucessos dos gurus já citados nesta tese (Chalita, Içami Tiba e outros), pois todos se valem de alegorias para contentar os professores. É preciso entender que, no mundo contemporâneo, a propaganda tenta tomar esse lugar - ensina, por exemplo, que ser livre é usar a roupa tal, que ser esperto é ter o que o outro não pode ter (por exemplo, uma boneca Hello Kitty) e que se alimentar bem é introduzir as comidas de marca nos hábitos alimentares (existem crianças que não comem mais uma manga, uma laranja, uma fruta, pois só o fazem por meio do sorvete $X$, do suco $Y$, do extrato da fruta; existe um marketing cada vez mais vigoroso e aplicado em departamentalizar o universo infantil e voltálo para o mercado. A direção do olhar que vê a fruta madura deverá

81 Belintane, 2009 (o já famoso Transtorno do Déficit de Atenção e de Hiperatividade é abordado neste artigo, que propõe nossa concepção de oralidade como medicação no lugar do Metilfenidado). 
olhar para sua foto na embalagem. A fantasia com seus mistérios e heróis, nesse meio discursivo, será sempre engolida pela bulimia.

Quanto mais os homens puderem ter de niñez, narrativas, poesia e fantasia na alma, tanto mais terão em criatividade e resistência para fazer da cidadania algo mais do que uma palavra desgastada pelo uso vulgar. Nossa intenção é fazer falar o "dada" da cidadania, levando-a para além das fronteiras da cidade. Entre os mitos, lendas, contos de encantamento, cantigas e ludismos do cotidiano há intervalos e canais por onde uma subjetividade, sem perder suas raízes regionais, pode encontrar o universal: entre o mito do fogo dos Xavantes e a tragédia de Prometeu pode vicejar uma subjetividade pronta para uma cidadania que vai além da cidade consumista.

\section{A ESCRITA QUE SE (RE)DESCOBRE A PARTIR DA ORALIDADE}

Como mostramos no capítulo I, a distinção moëbiana entre oralidade e fala cotidiana abre espaço para uma subjetividade de permeio, para nós indispensável à (re)descoberta da leitura e da escrita. As narrativas míticas, de encantamento, de aventuras e outras, que instigam o desejo de continuar a saber, aliadas aos gêneros da infância e da tradição oral, constituem o que nomeamos "oralidade". Nossa aposta ${ }^{82}$ consiste em uma metodologia ${ }^{83}$ que tenha como base essa oralidade, que se abre na forma de matrizes e de pujança psíquica para a escrita. A escolha desses gêneros e de seus textos principais tem como referência e inspiração o

82 Chamamos "aposta" a uma hipótese já experimentada, com razoável nível de confirmação em experiências controladas (como a que mostraremos no capítulo III), mas ainda não verificada em larga escala.

83 Para nós, metodologias são necessárias no ensino, pois não basta ter uma concepção ou filosofia e deixar o campo aplicado por conta dos professores. Uma metodologia pode ser dialética, bem contextualizada e propensa a sentir os inevitáveis efeitos de um real arredio, complexo, indomável. 
inconsciente linguageiro de Freud ou aquela dimensão que Lacan chamou "lalangue", de cujas bordas emerge uma língua/linguagem constitutivamente ambígua, polissêmica, sempre propensa à função poética e ao equívoco.

Para facilitar a leitura do capítulo seguinte, que é basicamente a aplicação desta concepção, pretendemos no tópico abaixo mapear mais ou menos esse campo e evidenciar a função de cada gênero ou de cada estratégia linguageira.

GÊNEROS DA ORALIDADE E ESTRATÉGIAS LINGUAGEIRAS FUNDAMENTAIS PARA UMA ALFABETIZAÇÃO DINÂMICA

Como vimos no capítulo I, a criança já nasce enredada pela linguagem. Desde os seus primeiros momentos, a voz parental, com nítida prevalência da materna, já potencializa a relação entre o ver e o escutar, que gradativamente vai se matizando da dialética do desejo, onde o outro parental tem um papel estruturante. Nessa alteridade nascente, os gêneros e textos oriundos da tradição da maternância jogam um papel crucial, pois abrem uma fissura entre o utilitarismo da sobrevivência e o espaço da fantasiação. Alguns deles podem e devem ser içados para o ensino, mas, sempre possível, respeitando as versões locais. Nas fases iniciais do Ensino Infantil ou mesmo desde o berçário e a creche, o educador tem que se preocupar com repertórios e com certa diversidade. Para esse período, recomendamos um agrupamento de gênero - esta nossa tipologia leva em conta as feitas por Cascudo (1998b) e Weitzel (1995), mas procura adaptá-las mais às possibilidades de uso desses textos no ensino infantil e nas séries iniciais do ensino fundamental. 


\section{a) Gêneros poéticos da maternância}

1. Cantigas de ninar: - São cantigas que as mães, pais, babás (antigamente mucamas) canta(va)m para acalmar ou adormecer crianças. Essas cantigas vieram sendo joeiradas esteticamente pela tradição, refinando suas métricas e ritmos e, em muitos casos, simplificando e readaptando seu léxico em função dos contextos regionais. Certo mistério da voz materna e do aconchego parental parece habitar seu ritmo embalante e sua temática extemporânea. Se todo texto ou gênero contém seu outro, sua alteridade, seu já dito, o outro da cantiga de ninar reveste-se de uma poética paradoxal, em que algo de milenar e distante vem amalgamado a um sentimento de forte presença parental. Sua temporalidade é moëbiana por excelência: um arrepio de um aqui-e-agora assimilado por uma sensação de eternidade. Não é por acaso que muitos poetas e músicos retomam com frequência esses textos em suas composições. Mencionaremos apenas um exemplo, que utilizamos com frequência na sala de aula: uma bela paródia de Francisco Marques (Chico dos Bonecos):

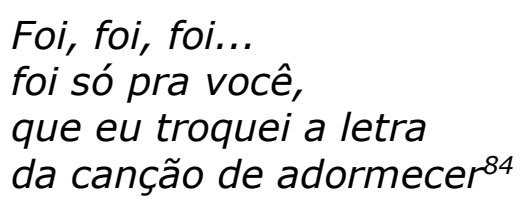

É interessante ver crianças de seis anos redescobrindo um outro texto dentro dessa valise mágica.

Outra atividade interessante em sala de aula é instigar os alunos a redescobrirem as cantigas do passado, como esta abaixo, que faz parte da coletânea de Antonio Nóbrega ${ }^{85}$,

\footnotetext{
${ }^{84}$ Recolhida em apresentação do artista em nossas aulas.

${ }^{85}$ CD: Brincadeiras, Estórias e Canções de Ninar, organizado por Antonio Nóbrega, 1993.
} 
recuperada da memória de Ester Pedreira de Cerqueira, uma senhora idosa do Recife:

Sussussu, ó menino o que é que tem?

Sua mãe foi à fonte, logo vem!

Foi comprar panelinha de vintém,

bacalhau com azeite, sabe bem...

Com a cantiga ressoando no fundo de nossa intimidade, ressoa junto a pergunta: o que seria panelinha de vintém? E o bacalhau com azeite... que... sabe bem?

Se Freud (2006) ${ }^{86}$ viu no jogo do For Da vivido por seu netinho uma experiência de substituição, em que a ausência da mãe é substituída pelo ir e vir do carretel embaixo da cama, através de um cordão cujo manejo (fazer desaparecer na escuridão da cama e fazê-lo reaparecer) e domínio conferem prazer e segurança ao menino, podemos considerar as cantigas de ninar e outros gêneros da maternância como um importante elemento dessa mesma natureza, mas no âmbito da língua e da linguagem. Se, de um lado, no nicho parental, figuram as conversas cotidianas, com seus "nãos" e imperativos, de outro, figura essa voz, que no silêncio da solidão pode ser retomada e repassada como se fosse o cordão do Fort $\mathrm{Da}$, que faz o jogo de esconder e revelar os encantos maternos.

Os textos das cantigas, na época das mucamas, costumam tematizar a ausência da mãe (como é o caso dessa) ou do pai (ou de ambos) e, algumas vezes, alertando para um perigo iminente nos arredores da $\operatorname{casa}^{87}$ (Xô Papão, de cima do telhado/deixa esse menino pegá sono sossegado).

\footnotetext{
${ }^{86}$ Volume II. Além do Princípio do Prazer (1920)

87 Freyre (2001, p. 382) mostra que os medos, as cantigas e histórias oriundas de Portugal aqui se modificaram sob a bela voz das mucamas: Também as canções de
} 
A voz melodiosa na memória substitui a perda, conforta, dá segurança. Esses textos, como desconfiava Manuel Bandeira (capítulo I), guardam um parentesco fundador com a poesia e com a função poética; podemos até dizer que eles fundam um outro uso da língua, paralelo ao uso pragmático do cotidiano como mostramos, no cotidiano os dois usos se retorcem na faixa moëbiana e se impregnam mutuamente.

1. Parlendas, brincos e mnemonias: Diferentemente das fórmulas de escolha e outros textos que relacionam voz e movimento, o grupo das parlendas se define pelo nonsense, pelo prazer de declamar um texto (sozinho, em dupla ou em grupo) deixando se levar pelo ritmo do significante. Pouco importam os sentidos, pois não há outra intenção senão a de memorizar e dizer o texto integralmente. Vejamos dois exemplos:

\begin{tabular}{|l|l|}
\hline O TOICINHO & - Tá dentro da igreja. \\
- Cadê o toicinho daqui? & - Cadê a igreja? \\
- O gato comeu. & - Tá cheia de gente. \\
- Cadê o gato? & - Tá aque gente? \\
- Foi pro mato. & - Tá ali... \\
- Cadê o mato? & - Tá aqui..88 \\
- O fogo queimô. & \\
- Cadê o fogo? & Pede cachimbo \\
- A água apagô. & \\
- Cadê a água? & Hoje é Domingo \\
- O boi bebeu. & pé de cachimbo \\
- Cadê o boi? & cachimbo é de ouro \\
- foi massá trigo. & bate no touro \\
- Cadê o trigo? & touro é valente \\
- A galinha ciscô. & chifra a gente \\
- Cadê a galinha? & a gente é fraco \\
- foi botá ovo. & cai no buraco \\
- Cadê o ovo? & o buraco é fundo \\
- O frade bebeu. & acabou-se o mundo. \\
- Cadê o frade? & \\
- Tá rezando missa. & \\
- Cadê a missa? & \\
\hline
\end{tabular}

berço portuguesas, modificou-as a boca da ama negra, alterando nelas palavras; adaptando-as às condições regionais; ligando-as às crenças dos índios e às suas. Assim a velha canção "escuta, escuta, menino" aqui amoleceu-se em "durma, durma, meu filhinho".

${ }^{88}$ Algumas parlendas, é o caso desta, finalizam seu texto com cócegas no interlocutor. 
A parlenda associa ritmo e rima a um efeito de encadeamento em que algumas palavras constituem uma espécie de coesão pelo sentido, mas o efeito geral é sempre de nonsense, ou seja, de produzir uma repetição significante sem se importar com o sentido. A intenção da brincadeira é realçar a capacidade de memorizar seguindo o ritmo ou então uma sequência de eventos.

Veríssimo de Melo (1985) identifica o brinco como um tipo de parlenda que pede brincadeira corporal; no caso abaixo, criança (em geral nos primeiros anos de vida) e adulto dão as mãos e produzem um movimento de vai-e-vem mimetizando a serra.

\footnotetext{
"Serra serra serrador Serra o papo do vovô Quantas tábuas já serrou? Já serrou vinte e quatro! Uma, duas, três e quatro!"
}

Outro gênero seria o nonsense - versos sem sentido, em que prevalece o prazer de rimar:

"Meio dia, o macaco assobia Na casa da tia"

Outro exemplo: as mães, no interior de São Paulo, costumam dar respostas nonsenses quando seus filhos demandam alguma coisa fora do propósito ou da hora:

"- Mãe, tô com fome!

- Mata um home e come!"

\section{b) Gêneros da infância mais ampla (além da maternância)}

2. Cantigas de Roda: Segundo Weitzel (1995), as cantigas de roda compõem a maior parte do cancioneiro infantil. Suas letras melodiosas muitas vezes fornecem matrizes para os poetas e 
compositores da Música Popular Brasileira. A criança que traz algumas delas na memória conta com matrizes importantes tanto para facilitar o domínio da leitura como para assimilar outros poemas. Vejamos aqui o poema Paraíso, de José Paulo Paes, feito a partir da cantiga "Nesta Rua":

\begin{tabular}{|l|l|}
\hline Nesta rua tem um bosque & Paraíso \\
\hline Se esta rua se esta rua fosse minha & Se esta rua fosse minha \\
Eu mandava, eu mandava ladrilhar & Eu mandava ladrilhar, \\
Com pedrinhas, com pedrinhas de brilhante & Não para automóvel matar gente, \\
Para o meu, para o meu amor passar & Mas para criança brincar \\
& Se esta mata fosse minha \\
& Eu não deixava derrubar \\
& Se cortarem todas as árvores \\
& Onde é que os passáros vão parar? \\
& Se este rio fosse meu \\
& Eu não deixava poluir \\
& Joguem esgotos noutra parte \\
& Que os peixes moram aqui \\
& Se este mundo fosse meu \\
& Eu fazia tantas mudanças \\
& Que ele seria um paraíso \\
& De bichos, plantas e crianças \\
( 2006, p.12) & \\
& \\
\hline
\end{tabular}

3. Fórmulas de escolha: Esse gênero era e ainda é (agora bem menos do que no passado) utilizado pelas crianças para escolher o pegador (no pega-pega), ou o bate-cara (no jogo do esconde-esconde), ou ainda a sequência de jogadas em qualquer tipo de jogo. Os folcloristas em geral o incluem no rol das parlendas, mas aqui fizemos questão de diferenciar, pois 
sua performance é singular e bem marcada: todos os alunos estendem as mãos, enquanto o texto é dito de forma cadenciada, tentando fazer coincidir fragmentos de palavras ou de frases com batidas nas mãos dos participantes. O exemplo mais conhecido talvez seja o

\author{
"Uni, duni, tê! \\ Salamê-mingüê \\ Um sorvete colorê, \\ o escolhido foi você!"
}

Mas há muitos outros. No almanaque do Folclore da Cidade de Olímpia89, em um repertório de mais de cem textos, encontramos este, escatológico, mas bem engraçadinho:

\footnotetext{
"Uma velha, bem velhinha, fez xixi na canequinha, foi contar para a vizinha Que era caldo de galinha."
}

Na mão em que cair o NHÁ de GALINHA se identificará o escolhido, a vítima da brincadeira; ou, em uma outra versão, as mãos sobre as quais cai o NHÁ vão se livrando e a vítima será o último que ficar na roda. Notem que o que temos nessa brincadeira é algo próximo à escansão de um poema em suas sílabas poéticas. Claro que aqui as unidades dependem do ritmo da criança que administra o jogo, muitas vezes o que se escande é um pouco mais que a sílaba, mas, de qualquer modo, o gênero permite um belo trabalho entre gesto corporal e unidades sonoras, por ser um bom caminho na busca de uma língua escandível, alfabetizável. Infelizmente, nem todos os alunos dominam essa posição subjetiva, a do que diz o texto e o distribui pelas mãos dos colegas. Cabem, então, ao

\footnotetext{
${ }^{89}$ www.folcloreolimpia.com.br (consultado em 06/09/2011)
} 
professor, algumas indagações de natureza avaliativa: Será que todos os alunos da classe conseguem fazer isso? Será que conhecem outros textos iguais a este (do mesmo gênero)? Quais? Qual é o repertório da classe? Como pode ser aumentado?

Estas são perguntas típicas de um bom diagnóstico oral. Só para se ter uma ideia, ilustremos aqui com um fragmento de caso: Michael, aluno de 9 anos, em nosso atendimento, do mesmo modo que, ao brincar com o ábaco, não mantinha a correlação entre ordinalidade e cardinalidade (dizia a sequência dos números, sem correlacioná-la à quantidade de bolinhas que separava em cada linha), também não pareava as sílabas ou palavras aos tapinhas que dava em suas mãos e nas do professor, pois pronunciava tudo num só ritmo, demonstrando uma posição subjetiva descadenciada do ritmo, incapaz de escandir e de brincar com os fragmentos das palavras e frases.

Alguns outros gêneros que, com este, podem constituir um agrupamento que permite trabalhos similares (relação entre declamação e destreza corporal):

- Fórmula de pular corda: O texto que é proferido no ritmo da corda e dos pulos; abaixo, apresentamos o exemplo mais utilizado pelas professoras para memorizar a sequência das letras do alfabeto:

"Suco gelado
cabelo arrepiado
qual é a letra
de seu namorado:
a, b, c, d, e....z"

- Fórmula da bola na parede: Jogando uma bola na parede e pegando-a de volta, a criança diz uma sílaba ou palavra do texto a cada ida e retorno da bola:

"Or - dem!

Em seu lu-gar (a criança se posiciona) 
Sem rir! (deve conter o riso mesmo que as outras provoquem)

Sem falar! (fecha a boca)

Uma das mãos... (pega a bola com uma só mão)

a outra! (pega a bola com a outra mão)

Um dos pés...

ao outro!

Bate palma!

Pirueta! (gira os braços, fazendo um moinho)

Meia volta! (roda em torno do corpo)

Volta e meia! (roda ao contrário)

(outros movimentos são acrescentados de acordo com a criatividade

de cada grupo)"

Há muitos outros textos cantados ou declamados que relacionam palavra-corpo-movimento; alguns exemplos: Escravos de Jó, Eu era assim..., O rabo da serpente, Tumbalacatumba. O que eles têm de interessante e que faz banda com a escrita é a destacabilidade das palavras na frase ou de fragmentos destas; em outras palavras, esses jogos se dão entre o que se diz e 0 que se marca com o corpo. Nesse contexto, é bom o educador associar que a essência do alfabeto é justamente a descoberta dessa destacabilidade e que esses jogos não deixam de ser uma busca intuitiva do lado articulável da língua (primeira e segunda articulação) e, ainda, como eles se estabelecem entre língua e corpo, podemos ter aí uma "mezinha" escolar contra o TDAH.

Fica também evidente que, nesse campo "palavra-corpo", o espaço interdisciplinar da alfabetização com a educação física é bastante evidente. Em nossos cursos de formação, sempre recomendamos que se elabore um projeto em que esses gêneros orais muito performáticos (com uso de bola, corda etc) fiquem por conta do professor de educação-física e sua relação com a escrita e com ilustrações fiquem por conta do professor alfabetizador e do professor de artes. 


\section{Adivinhas e Enigmas}

Em Adivinha, leitura e escritura de desejo (Belintane, 2006), abordamos a adivinha como uma espécie de alegoria ${ }^{90}$ para entender um pouco o campo da leitura a partir da oralidade. Partindo do mito de Édipo, como o homem que ousou enfrentar o "decifra-me ou devoro-te" da esfinge, detectamos duas posturas subjetivas diante do Outro, que as adivinhas propõem:

- Postura de adivinhador : A que, sem temer a ameaça de devoração da esfinge, aceita memorizar o texto proposto e, entre seus fragmentos, deixa correr outros textos advindos de sua memória linguística e discursiva. Como dissemos no texto, ...enfrenta as armadilhas do enigma, as associações arbitrárias, as falsas contradições, as metáforas e metonímias exageradas (p.136), o que constitui basicamente a essência da esfinge;

- Postura de evitador: A que não entra no jogo, que apenas assume a postura passiva diante do propositor do enigma, esperando sua benevolente resposta. Seguindo o mito do Édipo, seria um cidadão tebano com pouca vocação para ocupar o lugar do rei ou mesmo do pai, ou seja, é aquele que, amedrontado pela esfinge, evita a dor, a angústia diante do perigo da devoração.

A adivinha possui em sua tradição milenar uma relação umbilical com a escrita e a leitura. Na leitura, por exemplo, de um artigo de jornal, podemos pensar naqueles leitores evita-dores, que apenas assumem as verdades do outro sem correr nenhum risco de esvaziá-las um pouco, de entrar no campo do nonsense para

90 Sabemos que Goodman (1997) também comparou o ato de leitura ao de adivinhar e, por isso, sofreu inúmeras críticas, sobretudo dos defensores do método fônico (BRASIL, 2003/2006). Ressaltamos que nossa abordagem da adivinha é muito diferente da apresentada pelo autor americano, pois em vez de focar na adivinhação de palavra durante a leitura, procuramos estratégias para reaproveitar as habilidades linguísticas e o posicionamento subjetivo do ato de adivinhar para o ato de ler - isso pode ser constatado em Belintane (2007). 
dali explorar suas possibilidades linguageiras. Felizmente, há também os adivinhadores, os que desmontam os nonsenses das alegorias, que não aceitam essa ou aquela metáfora, que percebem os ardis das metonímias e que quase sempre dessacralizam a esfinge com abusadas penetrações em sua aura discursiva.

Nossa hipótese insiste em que essa propensão ao jogo, a ocupar o texto do Outro sem barrar demasiadamente a subjetividade de entre-texto vem, inicialmente, de uma certa postura do sujeito diante do Outro enquanto língua e linguagem e, no mundo letrado, diante do Outro enquanto escrita - dessa estranha alteridade que se propõe como um sistema estendido para fora do corpo, mas que se apresenta com uma forma suspeita, com suas vinte e seis figurinhas esqueléticas, que estão mais para traços arbitrários do que para imagem ou mesmo som.

Para buscar as respostas do final do capítulo I e preparar o leitor para compreender a pesquisa que relataremos no capitulo IV, que reúne elementos para a nossa conclusão, é interessante interrogar sobre a relação oralidade e escrita - sem dicotomizála mas, ao mesmo tempo, mantendo as possibilidades de confrontos e conflitos entre os modos subjetivos de enlaçamento entre uma e outra. Vimos, por exemplo, que a oposição adivinhador e evitador ${ }^{91}$ pode ser um modelo explicativo, mas aqui queremos ir mais longe e estender esse modelo para outros textos da tradição oral.

Entretanto, antes de apresentarmos as adivinhas, é interessante, como fazem Weitzel (1995 p. 134) e Melo (1950 p. 35), distinguir seus subtipos. O primeiro acha sete subtipos, o segundo, oito. Em nossa busca de uma oralidade-escrita,

\footnotetext{
${ }^{91}$ Esse tema do impedimento e da angústia escrita foi abordado por uma doutorando minha: Sartore (2006).
} 
resolvemos distinguir apenas dois campos: o das adivinhas ou enigmas, que de fato propõem um problema com resposta coerente, e o da pegadinha ou da cilada linguística, que em geral marca ludicamente a intenção do logro, da exposição do interlocutor a alguma contradição ou ridículo. Vejamos alguns exemplos:

"- Qual é a diferença entre o navio, o tatu e a família?

- Não sei!

- O navio tem o casco embaixo, o tatu tem o casco em cima.... (a pessoa faz um longo silêncio para que 0 interlocutor exija a relação com o termo intencionalmente omitido).

- mas... e a família?!

- A família vai bem, obrigado!"

Note-se aqui a ambiguidade a que o interlocutor é submetido, de vez que sua pergunta é retomada com outro sentido pelo enunciador do jogo.

Bem comuns também são as pegadinhas que margeiam o campo da sexualidade, em que a intenção é expor o interlocutor a um ardil no qual este se revela como um "mente poluída", ou seja, enquanto sua interpretação penetra no proibido, uma resposta bem inocente é fornecida para contrapor a malícia do outro. No "Macunaíma" de Mário de Andrade, temos três belos exemplos quando o "herói" tem que enfrentar três enigmas (como nos contos populares) para escapar da morte. As adivinhas (no caso pegadinhas) são formuladas pela filha de Ceuci, a devoradora de gente. Se Macunaíma adivinhasse poderia seguir livre, caso contrário, seria devorado pela mãe da propositora do jogo:

- Vou dizer três adivinhas, si você descobre, te deixo fugir.

O que é o que é: é comprido roliço e perfurado, entra duro e sai mole, satisfaz o gosto da gente e não é palavra indecente?

- $\quad$ Ah? Isso é indecência sim!

Bobo! É macarrão! 
- $\quad$ Ahnn...é mesmo!...Engraçado, não?

- Agora o que é o que é: Qual o lugar onde as mulheres têm o cabelo mais crespinho?

- $\quad$ Oh, que bom! isso eu sei! é aí?

- Cachorro! É na África, sabe!

- Me mostra, por favor!

- Agora é a última vez. Diga o que é o que é: mano, vamos fazer/aquilo que Deus consente:/ajuntar pêlo com pêlo/deixar o pelado dentro. (1977, p 133-134)

Notem que, nas três, o que está em jogo é a malícia e não o jogo de adivinhar. Alguns outros exemplos coletados entre alunos de escolas públicas:

"- O que é um pontinho amarelo no meio do deserto? ....um yellowfante!"

"- O que a água falou para o peixe?.... Nada !"

Para um melhor aproveitamento escolar, resolvemos criar uma tabela com o objetivo de explorar os potenciais figurativos e as habilidades linguageiras que as adivinhas acionam, quer pondo em relevo a exploração da camada significante (efeitos sonoros), a exploração de figuras de linguagem (metáforas, metonímias, personificação, paradoxos etc.) ou ainda a exploração estética (adivinhas em verso, com ritmo, rima etc). No quadro seguinte daremos alguns exemplos, mas deixando claro que a nossa classificação não é fixa, é antes uma sugestão de exercício para o professor perceber o que há de "leitura" e de "estética literária" nas adivinhas. 


\begin{tabular}{|c|c|c|}
\hline $\begin{array}{l}\text { ADIVINHA } \\
\text { (EXEMPLARES } \\
\text { GÊNERO) }\end{array}$ & $\begin{array}{l}\text { FIGURA DE LINGUAGEM OU OUTROS RECURSOS } \\
\text { ESTÉTICOS QUE O TEXTO PÕE EM JOGO }\end{array}$ & $\begin{array}{l}\text { ALGUMAS DIFICULDADES A SEREM } \\
\text { CONSIDERADAS }\end{array}$ \\
\hline $\begin{array}{l}\text { Lindos castelos, } \\
\text { Lindos penachos, } \\
\text { Água nas cuias } \\
\text { Flores nos cachos. } \\
\text { (coqueiro) }\end{array}$ & $\begin{array}{l}\text { Metáforas ("castelos", "penachos") } \\
\text { Metonímia ("agua nas cuias"; "Flores nos cachos") } \\
\text { Ritmo, elipse do verbo ser (são lindos castelos!) } \\
\text { A adivinha como um todo compõe uma alegoria. }\end{array}$ & $\begin{array}{l}\text { Significado( penacho e cuia). } \\
\text { Sintaxe simples. } \\
\text { - }\end{array}$ \\
\hline $\begin{array}{l}\text { Tem folhas e não é planta, } \\
\text { Tem lombo e anda de capa } \\
\text { O estudante que o abandona } \\
\text { Da nota má não escapa. } \\
\text { (livro) }\end{array}$ & $\begin{array}{l}\text { Paradoxos } \\
\text { Catacreses (folha, lombo e capa) - retorno ao literal. }\end{array}$ & $\begin{array}{l}\text { Significados das palavras lombo e capa; } \\
\text { Pronome oblíquo "o" (dêixis do pronome) }\end{array}$ \\
\hline $\begin{array}{l}\text { Na água não se molha } \\
\text { No fogo não se queima. } \\
\text { (sombra) }\end{array}$ & Paradoxos & Desfazer os paradoxos \\
\hline $\begin{array}{l}\text { Galinha no choco } \\
\text { Cachorro late. } \\
\text { (chocolate) }\end{array}$ & $\begin{array}{l}\text { Jogo de palavra, palavra valise (chocolate : contém as } \\
\text { outras duas palavras: choco e late }\end{array}$ & Esvaziar e reutilizar o significante \\
\hline $\begin{array}{l}\text { Onde está o defeito no } \\
\text { rádio? } \\
\text { (no meio, rádio) }\end{array}$ & $\begin{array}{l}\text { Homofonia: (D feito, defeito). importância do espaço } \\
\text { intervocabular na definição de uma palavra quando se } \\
\text { considera a sua forma oral (defeito / d feito ) }\end{array}$ & $\begin{array}{l}\text { Desmontar a palavra defeito e } \\
\text { ressignificá-la }\end{array}$ \\
\hline $\begin{array}{l}\text { Sou a bela ave, a rara. } \\
\text { Tente o meu nome escrever } \\
\text { Leia-o de trás para frente } \\
\text { Que o mesmo nome vais ler! } \\
\text { (arara) }\end{array}$ & $\begin{array}{l}\text { Palíndromo (palavra que pode ser lida ou pronunciada } \\
\text { de trás para frente)/ homofonia (a rara e arara) }\end{array}$ & $\begin{array}{l}\text { Inverter palavras. Tratar a adivinha como } \\
\text { escrita. }\end{array}$ \\
\hline $\begin{array}{l}\text { Que é que tem no meio do } \\
\text { ovo? } \\
\text { (a letra V) }\end{array}$ & $\begin{array}{l}\text { Foco metonímico no significante. Ambiguidade da } \\
\text { palavra "meio do ovo" }\end{array}$ & Visualização da palavra (leitura de oVo) \\
\hline
\end{tabular}




\begin{tabular}{|c|c|c|}
\hline $\begin{array}{l}\text { Entrei no fundo do mar } \\
\text { Saí no fundo da areia, } \\
\text { Para meu nome decifrar } \\
\text { Pegue no "b "a" ba" e leia. } \\
\text { (baleia) }\end{array}$ & $\begin{array}{l}\text { Homofonia, } \\
\text { Personificação } \\
\text { Palavra ou expressão valise (encontra-se outra palavra na } \\
\text { releitura) }\end{array}$ & $\begin{array}{l}\text { Sair da personificação, } \\
\text { Juntar letras }\end{array}$ \\
\hline $\begin{array}{l}\text { Anda sempre na caneta, } \\
\text { É cumprida na prisão, } \\
\text { Reveste o corpo das aves, } \\
\text { É o mesmo que compaixão. } \\
\text { (pena) }\end{array}$ & $\begin{array}{l}\text { Metonímia (descobrir a parte) } \\
\text { Homofonia (cumprida/comprida) } \\
\text { Polissemia de pena }\end{array}$ & Semântica de pena \\
\hline $\begin{array}{l}\text { São sete irmãos: } \\
\text { Cinco têm sobrenome, } \\
\text { Os outros, um nome só. } \\
\text { (dias da semana) }\end{array}$ & Metáfora e personificação & $\begin{array}{l}\text { Conhecer os dias da semana e relacionar a } \\
\text { nomeação dos dias com a nomeação de } \\
\text { pessoas (sobrenomes) }\end{array}$ \\
\hline $\begin{array}{l}\text { Cintura fina } \\
\text { Perna alongada, } \\
\text { Toca corneta } \\
\text { E leva bofetada. } \\
\text { (pernilongo) }\end{array}$ & $\begin{array}{l}\text { Metonímias (cintura, pernas) } \\
\text { Metáfora (corneta) }\end{array}$ & $\begin{array}{l}\text { Relações metafóricas. Tomar a imagem do } \\
\text { pernilongo e seu comportamento para } \\
\text { reencontrar as metáforas. }\end{array}$ \\
\hline
\end{tabular}


Ginzburg (2001) mostra que o tema da adivinha já foi tomado, entre outros, por Chklovski, como modelo de texto para abordar o tema do estranhamento e, consequentemente, o da leitura do texto literário. Compara a perspectiva do formalista russo sobre o estranhamento a uma antiga estratégia de governo do imperador Marco Aurélio (II d. C), que formulava para si mesmo uma certa "epistemologia" do estranhamento cotidiano a partir das adivinhas. O ponto de partida do imperador, guardadas as devidas diferenças, está próximo de uma preocupação pósmoderna - Lacan, Derrida e outros - o famoso "cancela a representação". Para Marco Aurélio, a forma estóica de suspender a representação (entendida como fantasia) tinha como objetivo suspender também a emoção, o sentimento. Era compreendida como passo necessário para alcançar uma percepção exata das coisas, e portanto atingir a virtude." ( $p$. 19).

Essa técnica de estranhamento lançava mão de alguns procedimentos, por exemplo, subdividir um objeto em suas partes constitutivas como forma de minimizar o poder do todo. Um fenômeno como a relação sexual, se submetido a uma dissecação fria, no caso, o copular, não passaria de "esfregação de uma víscera e secreção de muco acompanhadas de espasmos". A técnica do imperador, segundo Ginzburg, uma técnica de estranhamento, está muito próxima do jogo analítico exigido pelas adivinhas:

A auto-educação moral requer, antes de mais nada, que se anulem as representações erradas, os postulados tidos como óbvios, os reconhecimentos que nossos hábitos perceptivos tornaram gastos e repetitivos. Para ver as coisas devemos, primeiramente, olhá-las como se não tivessem nenhum sentido: como se fossem uma adivinha (p. 22). 
Mais adiante, completa a reflexão relacionando os procedimentos de estranhamento com a técnica das adivinhas e vê aí uma relação circular entre cultura popular e erudita:

A possibilidade de que Marco Aurélio tenha se inspirado num gênero popular como as adivinhas se afina bem como uma idéia que me é cara: a de que entre cultura douta e cultura popular costuma existir uma relação circular (p. 23)

Apesar dessa finalidade defensiva e moralista de Marco Aurélio e de que Ginzburg, ao longo desse artigo, faz questão de tornar evidente que há diferenças entre as técnicas de estranhamentos em diversas acepções literárias (por exemplo, entre as técnicas de estranhamento propostas por Marco Aurélio, Tolstoi, Dostoievski e Proust), o que fica claro para nós nessas aproximações é que a adivinha - como um jogo popular que atravessa as mais diferentes e afastadas culturas - pode ser uma chave importante para compreendermos melhor o ensino da leitura. Talvez, desse olhar zombeteiro que se posta diante de um código tendo como referência o mundo dos sentidos, dos jogos significantes e suas relações paradoxais com o mundo sensível, abstraímos alguns caminhos para aproveitar melhor o que há de poder inscritivo na tradição oral - em outras palavras, como tais textos ao mobilizar um jogo intertextual na memória, além de mobilizar um sujeito que se posta no hiato interpretativo que se abre entre um texto atual (aquele recebido no momento) e outros que advêm da memória como ferramentas de interpretação, põem também em jogo habilidades inferenciais da mesma natureza das exigidas nas leituras mais complexas.

$\mathrm{Na}$ poesia popular, os cantadores costumam também pôr o parceiro em apuros diante de adivinhas em versos. O prêmio é a consagração popular como violeiro esperto que, em versos, 
escande as armadilhas do outro. Vejamos um trecho da peleja entre Chica Barrosa e José Bandeira ${ }^{92}$ :

Pois agora Zé Bandeira, Responda o que eu lhe disse:

É rapa sem sê de pau, Rapa sem sê de cuié, É rapa e não rapadura, Me diga que rapa é.

- É rapa sem sê de pau, Rapa sem sê de cuié, Eu já te dou o sentido Te digo que rapa é: É rapaz e é raposa, Rapariga e rapapé... 7

Sim sinhô, seu Zé Bandeira, Já vejo que sabe lê:

Pelo ponto que eu tou vendo Inda é capaz de dizê O que é que neste mundo O homem vê e Deus não vê.

- Barrosa, os teus ameaço Eu não troco pelos meus: O home vê outro home Mas Deus não vê outro Deus!

Temos nesse jogo, além da adivinha, uma outra lei. A da métrica, do ritmo e a da rima. O cantador possivelmente já conhece a adivinha, cabe-lhe, no entanto, a difícil tarefa de metrificar a resposta, de encaixá-la na estrofe, no esquema rímico. O interessante nessa peleja é que a habilidade em lidar com a adivinha leva Chica Barrosa a concluir que seu adversário sabe ler - que é a tese que aqui e em outras publicações viemos defendendo. O saber ler aqui nesta adivinha-peleja é exercer o jogo que interpreta uma escritura (ainda que oral) para sair de seu visgo, de sua tensão imobilizante. Novamente, podemos pressupor aí um ouvido-olhar-leitor, um posicionamento

92 Leonardo Mota, Cantadores. (pp.175,176) 
subjetivo que permite lidar com semelhanças sonoras e formais em gêneros que fixam o espaço sonoro-visual da estrofe. Em alguns de nossos textos de divulgação costumávamos brincar com as palavras para situar esse reposicionamento; dizemos que o jogo é "descolativo" ou de "escola ativa" na medida em que desafia o eu a sair da sideração e a deixar as coisas por conta de uma subjetividade que se arrisca.

A etapa de produção de texto a partir de adivinhas é de uma riqueza espetacular. As crianças criam a partir de um objeto dado ou encontrado por elas. A idéia é esconder um objeto usando palavras, de tal modo que o interlocutor seja ludibriado pelas aparências do texto e não o encontre. Vejamos alguns exemplos, sempre partindo de um objeto bem conhecido:

1. OBJETO "lápis" - podemos pensar na forma (magro, comprido, com ponta) e na função (escrever, rabiscar, desenhar) e no modo de usar (entre os dedos). A primeira coisa que podemos fazer é personificá-lo, confundi-lo com uma pessoa:

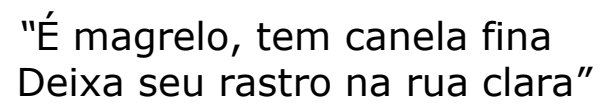

Aqui a criação ainda não tem rima, nem ritmo, mas isso pode ser melhorado:

\footnotetext{
"Magrelo, magrelinho

De pezinho afiado

Deixa marca no branquinho

Deixa rastro alinhado"
}

Nessas suas transformações estéticas (metáforas, metonímia, personificação, rimas etc) vai ficando cada vez mais parecido 
com um poema. Note como a criança pode ler o poema abaixo como se fosse uma adivinha:

\section{O marujo}

Marinheiro pequenino

bebeu água ao se deitar

acordou de madrugada

sua cama era um mar

(Paes, p.16)

Quem é o marinheiro do poema acima? Ele é de fato marinheiro?

A leitura inferencial - a única que de fato interessa - tem na adivinha uma matriz e um modo de posicionamento subjetivo dos mais caros e importantes para o ensino de leitura. Infelizmente, sua inserção na prática se dá sem o menor cuidado. Em geral, é tratada sem levar em conta seu aspecto performático, apenas como escrita. A voz de esfinge que tira da memória uma adivinha e a atitude do adivinhador que a põe na memória para analisar suas ciladas linguísticas em geral não são levadas em conta. Mas, concluindo esse tópico: a adivinha é uma arma contra o mundo parafrástico cotidiano.

\section{B. OUTROS LUDISMOS LINGUÍSTICOS (NÃO NECESSARIAMENTE EM FORMA DE VERSO)}

1. RÉPLICAS : São textos nonsenses, fáceis de memorizar, que consistem em um diálogo "esperto" por meio do qual uma pessoa brinca com a outra:

"- Mãe, tô com fome!

- Mate um home e come!"

"- Deixa eu vê?

- Num vai chovê?"

"- Tá com frio? 
- Tô!

- Bate a bunda no rio

- Tá com calor?

- Tô!

- Bate a bunda no tambor!"

Sua malícia ingênua e sua forma de diálogo contribuem com a leitura de diálogos em que ocorre duplo sentido, ironia e outras contendas verbais. Também é importante frisar que os escritores, não raro, revisitam esses nonsenses; veja abaixo, mais uma vez o poeta José Paulo Paes (idem ib. p.15):

- Vá plantar batata.

- Depois você descasca?

- Vá lamber sabão.

- Pois não. Mas me empresta a sua língua que a minha já está limpa.

- Vá ver se eu estou na esquina.

- Fui e nada vi: o bobo estava aqui.

- Vá caçar sapo.

- Cacei, aqui está: mande logo pro papo.

Weitzel (1995) apresenta uma coleção de mais de cinquenta "réplicas", mostrando o quanto esse gênero já foi produtivo no Brasil e como há de fato uma discursividade infantil que tenta fugir da monossemia e das regularidades da língua: nos exemplos de resposta do poeta, percebemos o jogo linguístico que vai do conotativo imaginarizado (uma expressão cristalizada: "vá caçar sapo!") à recuperação do literal (Cacei, aqui está: mande logo pro papo") e, ao mesmo tempo, proporciona à criança um algoritmo (simbólico), um ponto de giro no posicionamento subjetivo, pois o sujeito sai da posição de ofendida, menosprezada, para a de articulador de resposta. 


\section{LINGUAGENS SECRETAS - CRIPTOLOGIAS}

Em nossa pesquisa na escola pública, como se verá no capítulo IV, notamos que todos os alunos com problemas de leitura não conseguiam inverter um simples dissílabo, o que nos levou a propor o jogo do revestrés como conteúdo e estratégia para que os alunos dominassem mais facilmente o algoritmo silábico. Nos livros didáticos aparecem propostas de trabalhar linguagens criptográficas (enigmas, letras trocadas), mas em geral na escrita e não na oralidade.

Segundo Freud $(1988)^{93}$, inventar falas secretas é uma atividade típica das crianças, funciona como se fosse uma espécie de desrespeito à linguagem dos adultos, à imposição do código pelos adultos. Quando um pouco maior, a criança brinca com o código, criando linguagem secretas a que só seus companheiros próximos têm acesso. Freud cita o caso do Zittersprach, linguagem em que se adiciona o termo "Zitter" no início de cada palavra para confundir o interlocutor, como a nossa linguagem do Pê (veja quadro logo adiante).

Trabalhando com crianças com dificuldades de alfabetização, trabalhamos a linguagem do revestrés, iniciando pela inversão silábica de dissílabos:

PELPA (PAPEL), VROLI (LIVRO), TAPOR (PORTA)

Aqui estamos diante de um tipo de reversibilidade em que as sílabas são remanejadas para se encontrar o sentido. Atividade excelente não só para que o aluno assimile a sílaba como uma unidade destacável e reutilizável, como também para abstrair os efeitos da materialidade do próprio código. De fato, no início do jogo, qualquer que seja a palavra, ela só é reconhecida após a inversão; mas tão logo se tenha um repertório, o reconhecimento se dará de

\footnotetext{
${ }^{93}$ Vol. VIII: O Chiste e sua relação com o inconsciente. (1905)
} 
imediato, a unidade será reconhecida não pela articulação em si, mas pelo esboço sonoro geral. Essa atividade é essencial na leitura, pois enquanto o aluno, na tentativa de ler, ficar na decifração sílaba a sílaba, sabemos que sua leitura será lenta e dependente da subvocalização.

Quando introduzimos trissílabos e polissílabos, a montagem se torna difícil, mas o reconhecimento por traços sonoros mais gerais e pelo contexto vem suprir a dificuldade da silabação invertida. Vejamos um exemplo: MIRDECLAU - note que o fragmento CLAU predomina e funciona metonimicamente, sobretudo se o contexto for indicado antes (nomes de pessoas que estão presentes).

Uma brincadeira interessante é fazer a chamada usando os nomes invertidos: LOSCAR (CARLOS), NAÃRIMA (MARIANA), ACILU OU CIALU (LÚCIA), SARILA(LARISSA), COCISFRAN(FRANCISCO) mas tudo na fala, sem usar nada da escrita.

Interessante notar que a linguagem do revestrés, sobretudo nas cidades do interior ou nas periferias das metrópoles era muito utilizada pelas crianças para barrar os adultos. Em minha infância, o convite para ir nadar num ribeirão, próximo de minha casa, era feito diante dos adultos:

- Cevo iva jeo dana no istre tespom?! (você vai hoje nadá no treis pontes?

- Ue uvo. Repees ana rateipor. (eu vou. Espere na porteira)

Podemos dizer, com Freud, que aqui as crianças viviam um verdadeiro regalo subjetivo. O sujeito se movimenta entre o outro de uma língua de adultos que o vigia e o outro próximo, que compartilha a abusada subversão, em que certa lei do código se põe a favor da criança.

Há muitas outras linguagens secretas que podem ser utilizadas na escola. Vejamos alguns exemplos na tabela: 


\begin{tabular}{|l|l|}
\hline \multicolumn{1}{|c|}{$\begin{array}{c}\text { LÍnGUAS SECRETAS } \\
\text { (paulista) }\end{array}$} & $\begin{array}{l}\text { REGRAS } \\
\text { Intercalar a sílaba Pê entre as sílabas das } \\
\text { palavras: PEVOPECÊ PEFAPELA PENA } \\
\text { PELINPEGUA PEDO PEPÊ? }\end{array}$ \\
\hline Língua do Pê mineira & $\begin{array}{l}\text { Intercalar o fonema [P] e ao mesmo } \\
\text { também articulá-lo com a vogal anterior: } \\
\text { VOPOCEPE FAPALAPA NAPA LINPAGUAPA } \\
\text { DOPO PEPE }\end{array}$ \\
\hline Língua do Ferrê & $\begin{array}{l}\text { O princípio é o mesmo: } \\
\text { Voferroceferre fafarralafarra nafarra } \\
\text { linferrimguaferradoforro peferrê }\end{array}$ \\
\hline
\end{tabular}

Vejamos Mario de Andrade, mais uma vez provando que tira boa parte de seu Macunaíma de sua escuta dos jogos e folguedos populares:

(No capítulo "A velha Ceiuci", Macunaíma discute com Chuvisco, personagem alegórico que remete à renitente chuvinha paulistana):

Macunaíma ficou muito despeitado e perguntou para o rival:

- Me diga uma coisa: você conhece a língua do lim-pimgua-pa?

- Nunca vi mais gordo!

- Pois então, rival: Vá-pa àpa mer-per-da-pá! ${ }^{94}$

Quem revisita com frequência a história da escrita percebe claramente que a escrita é um dos capítulos mais importantes da criptologia. Singh (2001), ao discutir os grandes formuladores e quebradores de códigos, inclui na lista os decifradores dos hieróglifos (Thomas Young e Champollion) e da escrita cretense, a chamada Linear B (Michael Ventris e John Chadwick). O interesse pelas adivinhas, enigmas e criptologias orais exige uma postura de

\footnotetext{
${ }^{94}$ Mário de Andrade. Macunaíma: o herói sem nenhum caráter. São Paulo: Martins, 1977 (p. 130).
} 
leitor/decifrador (aqui, decifrador está no sentido de atribuidor de sentidos).

\section{TRAVA-LÍNGUAS}

Brincar com trava-línguas é uma atividade rica e extremamente útil para o professor resolver diversos problemas de fala e de leitura. Em nosso projeto recorremos a essa brincadeira basicamente com dois objetivos:

a) Resolver dificuldades com fonemas homorgânicos (que só têm um traço distintivo), tanto na pronúncia como na escrita.

[p] e $[b]$

- Enquanto o pinto pia a pinga pia.

- Bola bela a da Isabela/ Bela bala a da Isadora

[t] e $[d] ;$

É um dia, é um dado, é um dedo

- O Tatá tá?

- Não, o Tatá não tá, mas a tia do Tatá tá!

- Então, tá!

[f] e $[\mathrm{V}]$

Não sei se é fato ou fita, só sei que você me fita, me fita mesmo de fato.

Lá vem o velho Félix com seu velho fole

Tanto fede o velho fole, como fede o Velho Félix.

$[k]$ e $[j] ;$

O caju é do Juca e o cajá é do Cacá

Ou o cajá é do Juca e o caju do Cacá?

b) Trabalhar com encontros consonantais. 
Apresentar um trava-língua com encontro consonantal e em seguida "destravá-lo" permite à criança perceber a importância do R para marcar o travamento:

- Placa clara, clara placa.

- Palaca calara, calara palaca

Ou paca cara, cara paca

Essa brincadeira acelera a apreensão da estrutura ConsoanteConsoante-Vogal (CCV), que em geral atrasa a fluência da leitura. Aqui cabe registrar que o português de Portugal é um grande produtor de encontros consonantais, pois a pronúncia de seus falantes são sempre bem travadas:

\begin{tabular}{|l|l|l|}
\hline $\begin{array}{l}\text { PRONÚNCIA } \\
\text { PORTUGUESA }\end{array}$ & $\begin{array}{l}\text { NA ESCRITA PODERIA } \\
\text { SER UMA SÍLABA CCV }\end{array}$ & $\begin{array}{l}\text { PRONÚNCIA } \\
\text { BRASILEIRA }\end{array}$ \\
\hline$\left[b^{\prime}\right.$ rata $]$ & Brata & {$[$ barata $]$} \\
\hline$\left[c^{\prime}\right.$ roa $]$ & Croa & {$[$ coroa $]$} \\
\hline$\left[p^{\prime}\right.$ rada $]$ & Prada & {$[$ parada $]$} \\
\hline$\left[b^{\prime}\right.$ rita $]$ & Brita & {$[$ birita $]$} \\
\hline$\left[a b^{\prime}\right.$ lita $]$ & Ablita & {$[$ habilita $]$} \\
\hline
\end{tabular}

\section{PALAVRAS VALISES 95}

Algumas palavras, sobretudo as que se utilizam no chiste ou nos trocadilhos, apresentam a propriedade que consiste em portar em seu corpo uma outra palavra. Brincar de localizar a palavra que vai dentro da valise, além de ser divertido, ajuda tanto na alfabetização como na busca de um posicionamento subjetivo capaz

\footnotetext{
${ }^{95}$ Essa nomeação aparece em Jakobson (1995b, p.152 ) e também foi utilizada por Lacan em muitas ocasiões.
} 
de ler uma palavra ou frase buscando, além do significado, outras mensagens no significante (leitura assimilando a função poética). Vejamos alguns exemplos utilizados em nosso projeto com crianças das séries iniciais:
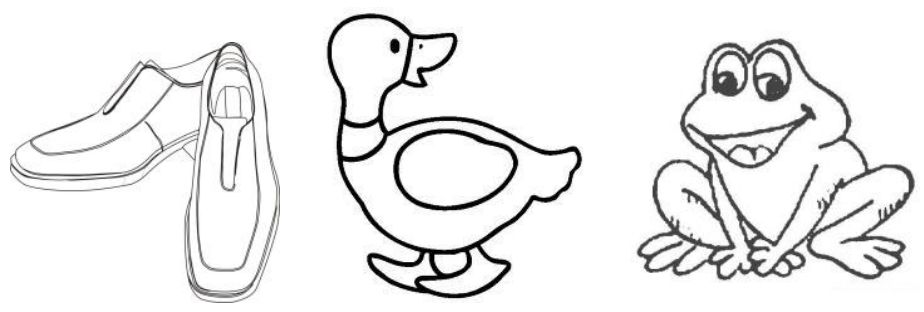

Dentro de sapato, podemos encontrar tanto um pato como uma sapa. Esta atividade pode ser feita sem recorrer à escrita, destacando a palavra a partir de imagens. Nós utilizamos imagens projetadas em que o sapato aparece primeiro, após a descoberta do pato, em um clique o sapato diminui seu tamanho e aparece a imagem do pato e, em seguida, a da sapa. A cada clique aparece também o nome sapato, que vai se desmontando em sapa e pato. Em nossas atuações nas escolas, construímos um repertórios de palavras-valise (repolho, chave, armário etc). Facilmente o repertório vira jogo (com imagens), adivinha e poesia.

c) NARRATIVAS ORAIS POPULARES:

Sempre levando em conta que a oralidade inicia-se no berço, com as cantigas parentais, é interessante pensar como as histórias também têm uma gênese parecida, que vai desde o nicho parental à grande literatura.

Desde muito cedo, os pais e outros adultos próximos contam histórias para as crianças. Em geral, são narrativas com tramas bem simples, como "Os três porquinhos", "Chapeuzinho Vermelho", "Os sete cabritinhos" e outras do repertório europeu. Como 
comentaremos mais detalhamente no próximo capítulo, em geral as histórias veiculadas pelos Estúdios Disney acabaram prevalecendo sobre o repertório popular brasileiro. Mesmo as narrativas dos grandes autores, como Pinóquio de Carlo Collodi, Peter Pan e Wendy de James Matthew Barrie, e as obras de muitos autores que eram bem reconhecidos há algumas décadas, hoje são vistas como obras do cinema, em geral dos Estúdios Disney.

Com histórias europeias ou brasileiras, ocorre que as crianças que desde muito cedo são submetidas a rituais de contação de história acabam também tomando a postura ativa de contador. Perroni (1992), em sua pesquisa sobre desenvolvimento da narrativa, mostra como a criança de quatro anos já começa a ganhar autonomia na elaboração de narrativas. Partindo de um posicionamento subjetivo inicial que não permite distinguir ficção de realidade, a criança vai, aos poucos, em geral sob a influência dos adultos, podando suas expansões e mesclas subjetivas com personagens, fixando a função do discurso narrativo e distinguindo e situando interlocutor, narrador e personagens. Para Perroni (p. 232-233), essas situações emergentes de construção do interlocutor são concomitantes à construção dos personagens como entidades independentes do narrador e ocorrem em razão da instanciação do adulto como interlocutor. Este fato leva a autora a concluir que a perspectiva sociointeracionista sai reforçada de sua pesquisa. De certa forma, podemos acompanhar a autora nessa conclusão, no entanto, fazemos questão de frisar que o mais importante desse processo é o reposicionamento subjetivo, ou seja, a mudança da posição de escuta para a de contador é que vai dar condições a uma criança de reutilizar as matrizes que foram se acumulando e se reformulando ao longo dessa primeira infância. Nesse processo, a história, personagens e a posição demiúrgica de narrador ajuda a criança a se distinguir da mãe e do pai e abrir caminho para o mundo na companhia de seus personagens. 
Para nós, educadores, independentemente de nossa postura teórica ou epistemológica, é importante compreender que essas histórias deixam suas matrizes e que estas são fundamentais para assimilar a leitura fluente e significativa, sobretudo de narrativas e de textos de grande extensão (livros de aventuras, por exemplo). Para além de qualquer postura desenvolvimentista, é sempre possível perceber que há no processo dessas crianças um entusiasmo em jogo, como disse Ortega y Gasset, ou, como diriam Freud e Lacan, certa economia de gozo, pois a criança adestra aí boa parte de sua maquinaria pulsional: em vez de descarregar energia sobre o corpo em ações (correrias, choros, manhas, brigas), investe-a em seus personagens, assumindo uma outra corporalidade, mais simbólica, mais independente do hardware corporal, que tem condições de acompanhar as aventuras dos personagens.

A contação de histórias, com todas essas oportunidades de intervenção do adulto ou com aquela severidade em que a criança não aceita intervenções ou mudanças nos detalhes do texto, deve ser assimilada pela educação infantil; e, em muitos casos, sobretudo aqueles em que se detecta, por meio de diagnósticos, que esta ou aquela criança não contou com a oportunidade de ter pais contadores (e também bons interlocutores), seus educadores devem se reposicionar para exercer aí uma função de suplência. Ou seja, o que não foi feito pelos pais pode ser reposto, principalmente quando as crianças (de creche ou do infantil) ainda estão em idade de aquisição da fala. Portanto, cabe aos educadores da Educação Infantil ter um bom repertório de histórias, de preferência com uma boa parte delas oriundas de tradições brasileiras. Vejamos um mapeamento simples do contínuo das narrativas populares do Brasil:

1. Histórias de bichos/animais: contos brasileiros que envolvem a onça e a cobra como animais ameaçadores; o jabuti, a raposa e o macaco como representantes da astúcia; 
os pássaros de nossa fauna (beija-flor, quero-quero, mutum, uirapuru) e a infinidade de fábulas, como as registradas no livro da poetisa e folclorista Henriqueta Lisboa (2002), em que comparece boa parte da fauna brasileira: $A$ onça e o coelho, $A$ raposo e as aves, $O$ gato e a raposa.

2. Lendas brasileiras: Matinta Pereira, O Mapinguari, Cobra Norato, o Curupira, O Saci, a Iara e muitos outros.

3. Causos brasileiros: as histórias de João Grilo e Pedro Malasartes, de assombrações, as contendas de caipiras com o diabo; as princesas, príncipes e reis deslocados de seus castelos medievais para o mundo caipira e sertanejo perdem a distância e solenidade e ficam acessíveis às trapaças de um Pedro Malasartes ou à coragem e astúcia de um Joãozinho qualquer.

Para dar conta desse belíssimo repertório, que tanto agrada às crianças (isso nós tivemos o prazer de constatar em pesquisa na escola pública - como se verá no próximo capítulo), bastaria o professor manter ao alcance das mãos algumas obras de folcloristas brasileiros: Sílvio Romero (2008), Câmara Cascudo (1998), Cornélio Pires (2002), Henriqueta Lisboa (2002), Alcoforado e Suárez Alban (2001) e de outros citados nesta tese. Recentemente a editora paulista Landy lançou várias coletâneas de contos populares dos mais diferentes países, de Portugal à China.

Concluindo este capítulo, reiteramos as críticas que fizemos aos programas governamentais e aos projetos de alfabetização e ensino da leitura que põem a escrita como algo pragmático, apenas útil, em uma dimensão de cidadania que parece dispensar a fantasia e as fontes originárias da literatura em nome de uma ideia de letramento que cultua o imediato, o prosaico do cotidiano. $O$ percurso que fizemos pela oralidade mostra que é possível alfabetizar com gêneros 
e estratégias que apontam para a dimensão criativa da língua e das linguagens, espaço simbólico onde prevalece a palavra elétrica, predisposta a revirar-se moëbianamente em significâncias que extrapolam o uso ordinário da língua ou o engaja em textos maiores.

No próximo capítulo, veremos a parte aplicada de nossa articulação teórica, apoiada em duas experiências: uma com alunos de uma escola da rede pública estadual situada na Zona Oeste da cidade de São Paulo; e de uma rica experiência com crianças e adolescentes de uma favela também da Zona Oeste da cidade de São Paulo. Além disso, acrescentaremos alguns dados já recolhidos de uma outra pequisa ainda em andamento, com alunos de três estados brasileiros: São Paulo (capital), Rio Grande do Norte (sertão: Pau dos Ferros) e Pará (periferia de Belém). 


\section{CAPÍTULO III \\ EXPERIÊNCIAS E PESQUISAS}

Neste capítulo, pretendemos mostrar resultados e reflexões a partir de dados de nossas pesquisas e experiências realizadas nos últimos cinco anos. Munidos especialmente das hipóteses de que a oralidade faz a escrita e de que a falta de uma memória linguageira torna o processo da alfabetização mais difícil e penoso, sobretudo para a criança pobre, partimos para o campo aplicado. Nos últimos quatro anos realizamos a pesquisa na Escola Keizo Ishirara ${ }^{96}$, com duração de dois anos (agosto de 2007 a agosto de 2009) e, ao mesmo tempo, experimentamos, juntamente com alguns orientandos, uma convivência que de três anos (2006-2009) com crianças de uma favela também da Zona Oeste ${ }^{97}$. Como já dissemos no capítulo II, com os dados dessas duas experiências iniciamos uma outra mais ampla, em fevereiro de 2010 (a Pesquisa em Rede, para a qual analisamos, no capítulo anterior, os três manuais didáticos do PNLD.)

Para apresentar nossa reflexão, tomaremos como base a pesquisa finalizada (Zona Oeste de São Paulo), cujos resultados já

\footnotetext{
96 A pesquisa, financiada pela FAPESP, como já mencionado no capítulo anterior, foi realizada na Escola Estadual Keizo Ishirara, com crianças do ensino fundamental I. Essa escola, além de atender uma população de baixa renda, recebia também crianças oriundas de dois Abrigos da região, onde eram internados meninos e meninas de rua ou de famílias cujos pais perdiam o "direito de guarda".

97 Essa interessante experiência contou com o apoio da ONG, ACAIA, cuja missão é proporcionar possibilidades de inserção social a jovens e crianças das favelas que se expandiram em torno do CEASA. A instituição atende alunos no horário inverso ao do escolar, no período da manhã, recebendo crianças de até dez anos (fundamental I), e, no período da tarde, adolescentes na faixa de 11 a 17 (fundamental II e segundo grau). O objetivo inicial da Instituição era reunir as crianças em torno de ateliês (marcenaria, culinária, artes plásticas, gráfica, cinema). A partir de certo momento, os diretores perceberam que boa parte das crianças não conseguia aprender a ler na escola e que esta falta era um empecilho para a continuidade dos estudos ou mesmo para a inserção dos jovens no mercado de trabalho (os adolescentes faziam estágios em empresas: restaurantes, marcenarias, bancos e outros). Nesse contexto, fomos chamados para montar um plano de letramento e alfabetização para essa comunidade.
} 
resultaram em publicação ${ }^{98}$, e, na medida do possível, pretendemos inserir dados e reflexões oriundos das outras duas experiências (do ACAIA e da "pesquisa em rede", ainda em andamento).

\section{DIAGNÓSTICOS ORAIS}

No primeiro ano de nossa pesquisa, 2007, lançamos mão de um tipo de diagnóstico que, em vez de partir da escrita (ditado, leitura de lista de palavras, como fazem os professores e avaliadores que se inspiram no construtivismo de Ferreiro y Teberosky), procurava detectar - através de uma conversa informal que aos poucos envolvia o aluno em uma sequência de atividades lúdicas com textos da tradição oral - quais habilidades linguageiras o aluno teria disponível para lidar com a escrita. Do mesmo modo, seguindo o que discutimos no capítulo II, procuramos detectar o modo como o rébus e outras imagens poderiam fazer suas escansões enquanto imagens que podem ser lidas. O rébus aqui representava uma espécie de dobradiça entre o oral e o escrito, pois a imagem fornecia um nome, que com a habilidade linguageira da criança era segmentado e passava a ser "lido" como som (base do funcionamento ideográfico, como visto no capítulo I).

Já neste diagnóstico inicial, percebemos com clareza distinções entre grupos de alunos que predispunham minimamente de um jogo mais amplo com a função poética e aqueles que pareciam se aferrar mais à fala comunicativa. Os primeiros, assistidos por nossa equipe, em pouco tempo acabaram assumindo tanto os jogos orais como as aulas de leitura, ou seja, suas dificuldades estavam mais associadas a singularidades ocorridas no período inicial de alfabetização (conflitos com professores, mudanças sucessivas de endereço, ocorrências familiares, doenças etc.). Percebemos ali a emergência -

98 (Belintane, 2010a) - parte deste artigo será retomada aqui com modificações e acréscimos de dados e reflexões não aproveitados na ocasião. 
mesmo que ainda incipiente - do fenômeno que nomeamos como "subjetividade de entre-textos".

Com os integrantes do segundo grupo, percebemos algumas dificuldades mais complexas, uma espécie de impedimento subjetivo, pois quando diante de um texto oral ou de uma atividade lúdica (exemplos: repetir uma parlenda bem conhecida, inverter a ordem das sílabas de um dissílabo qualquer, associar uma palavra ou frase a uma história bem conhecida, narrar uma história ou mesmo um fato de seu cotidiano etc.), o aluno ficava aguardando a resposta ou um pareamento com o professor para ajustar sua participação.

Em outra pesquisa já publicada (Belintane, 2006b), em que tivemos a oportunidade de aprofundar um caso isolado (aluno que, mesmo após dois anos de escolarização ainda não lia), cunhamos o termo subjetividade renitente 99 , com o qual queríamos expressar essa condição subjetiva que põe o aluno em conflito com a escrita ou mesmo com as habilidades linguageiras oriundas dos textos da tradição oral. Se, como vimos no capítulo I, há crianças que, com apenas dois anos, conseguem evocar um texto memorizado dias antes (exemplos das crianças citadas no capítulo I), a partir de uma palavra ou expressão dita pelo outro ("tigela", "como se chama"), enlaçando textos integrais (cantiga do pato, "se essa rua fosse minha"), demonstrando, portanto, precocemente, uma habilidade intertextual, há outras que parecem bloquear essas associações e se apegar ao significado mais imediato da palavra. Como se, na presença do outro escolar (professor, escola, pais), Ihes fossem interditados possíveis movimentos entre significantes - como se a

99 O termo renitente é aqui uma apropriação metafórica que nos permite recuperar um outro contexto da palavra: no período de imigração dos italianos, muitos imigrantes eram registrados como renitentes, ou seja, os que desertavam ou fugiam da convocação do exército italiano. Não temos uma referência exata para esta informação, mas ela pode facilmente ser localizada em alguns registros de imigrantes no Museu da Imigração em São Paulo. Renitentes são alunos que não se alistam no sistema da escrita. 
escolarização, por exigir a "coisa certa", engessasse a relação significado-significante.

Essas duas possibilidades de manifestação subjetiva, embora não de forma muito homogênea, serão encontradas em nossos diagnósticos de leitura. Há crianças que se valem do contexto, de sua memória imediata ou remota, de seus conhecimentos sobre o gênero textual, enfim de suas flexibilidades metafórico-metonímicas e, sem muita solenidade, leem de forma fluente mesmo quando cometem alguns erros de leitura. Já outras parecem aferir cada elemento do texto, desde a correlação entre cada sílaba e seu som até o sentido de cada palavra - notamos que esse posicionamento subjetivo parece ser tributário de uma intensa repetição da antiga sacralidade da leitura em voz alta (capítulo I), que exige uma acoplagem solene e ideal entre a voz que lê e a pauta da escrita.

Essa condição subjetiva, que se prende ou se esvanece na decodificação ou nos significados de cada palavra, lembra-nos o caso relatado por Lúria (1999): S, um mnemonista que, apesar de conseguir memorizar imensas fórmulas de matemática ou extensas listas de palavras ditadas por alguém, não conseguia ler um conto de Tolstoi. Apesar de o episódio não ter sido bem aproveitado por Lúria, em razão de sua postura teórica ${ }^{100}$, em nossa leitura constitui um caso em que se pode perceber a dificuldade de se exercer a retroação, em razão de uma fixação em alguns dos elementos da leitura, no caso, na sucessão das imagens. Vale a pena explicitar um fragmento relatado pelo próprio $\mathrm{S}$ :

\footnotetext{
100 Lúria atribui pouco valor às estranhas nomeações de $S$, que lembram as nomeações de Schreber, o presidente da suprema corte, cuja obra, Memórias de um doente dos nervos (1995), foi analisada por Freud em seu famoso Caso Schreber (1988, volume XII) e abriu caminho para Lacan tematizar a psicose. Os efeitos linguageiros e as dificuldades com a retroação na leitura (capítulo I), evidenciados por S, constituem um rico material para estudos no campo da leitura e, como o fizemos, podem ser comparados com as dificuldades da criança que lê subvocalizando (fixando-se na imagem da letra ou no cotejo entre grafema e fonema).
} 
Leram-me a seguinte frase: " $N$ estava encostado numa árvore..." Eu via um jovem magro que usava um terno azul ( $N$, como você sabe, é muito elegante). Ele estava parado perto de uma grande Tília, com relva e floresta por toda a volta...Mas, então, a frase continuava: "e olhava com atenção uma vitrine". E agora, que tal Ihe parece isso? Isso significa que o cenário da cena não é uma floresta, ou um jardim, mas que ele se encontra na rua. $E$ tenho que retomar a frase desde o começo... (Registro de março de 1937) (p. 98

Em todos os seus relatos, $\mathrm{S}$ mostra que fixação demasiada nas imagens, aliás, as utiliza como peças de uma montagem e, com isso, evita o jogo de esquecer-lembrar presente na retroação, característica marcante do simbólico. Na psicanálise freud-lacaniana teríamos aí uma projeção do imaginário sobre o simbólico, com o real sendo praticamente alegorizado pelo imaginário.

O dispositivo escolar que fixa o sujeito na leitura conferida (ler sem erro, acoplar a voz com perfeição sobre as formas) talvez seja parte de um outro mais amplo, que apresenta a escola como a instituição cultivadora das formas corretas e ideais. Na exaustiva tarefa de conferir, o percurso subjetivo se torna refém dos elementos mais externos do texto (forma, som, significado) e não dinamiza o fluxo da leitura com os intertextos e recursos discursivos que sua memória poderia pôr em jogo. A concepção de leitura assumida pelo aluno (seja na escola, seja na cultura) parece funcionar como uma barreira de isolamento entre o texto que tem diante dos olhos e os outros recursos intertextuais e linguageiros que ele traz ou deveria trazer na memória. Não se constitui um espaço de jogo entre esses textos, nem ocorre o esvaziamento de sentido das palavras (ou mesmo do som), tampouco o efeito de retroação. Todo o esforço fica concentrado na correlação grafema-fonema, na identificação da sílaba e das palavras. Podemos dizer que temos aí uma subjetividade siderada pelo outro exigente da escrita escolar. A predisposição subjetiva seria regida por um imaginário pregnante, tensionada por 
um outro exigente e enrijecido, em que a única saída para o sujeito passa a ser uma atuação evasiva: deixar cair o lápis, pedir para ir ao banheiro, fazer perguntas alheias à aula (sobretudo em relação ao tempo: "já tá quase na hora do recreio?"); ou mesmo atuações mais diretas e agressivas, tal como fez um aluno: atirou todos os livros ao chão e disse claramente que não queria aprender a ler.

Esse fenômeno também pode ser observado e bem compreendido na produção textual de alunos que já conseguem dominar o código. Em Belintane (2009) analisamos dois textos cujos processos subjetivos seriam representativos dos dois perfis comentados acima. Antes de entrar nos dados da pesquisa apresentaremos uma rápida análise do texto 1 , para ilustrar 0 resultado produtivo desse modelo, que fixa o aluno e que também 0 prende ao seu cotidiano prosaico, e, mais adiante, apresentaremos o segundo caso, um aluno que aproveita os vazios do texto. Vejamos:

TEXTO 1 (aluno de quinta-série de uma escola municipal da zona oeste de São Paulo (Bairro Campo Limpo). A consigna se deu a partir de uma campanha da Eletropaulo, que incentiva os alunos a escreverem sobre o perigo de se empinar pipa debaixo dos fios da rede elétrica ${ }^{101}$ :

101 O educador precisa repensar essas demandas vindas de fora, que em geral propõem produções de texto, sempre na expectativa de uma resposta que interessa a esta ou aquela instância da sociedade. Desses processos se forma parte do repertório de lugares-comuns do imaginário politicamente correto, que requer do aluno apenas uma submissão. 
Este negussa das Pipa

Esta cada ufp mas Pirigt.

En que ria que paraci de vend

cerol $D$ orque esta cada viz

matando plssoas por favor

nao soute pipa comfia na

sua inamaé quande lla

falar $P$ ara ná sutar $P$ Lpa

Pina sa soute anter bul soutava soute Pipa a' Eupare ofe seu
um garoto feliz. M guroto

Analisando a trama discursiva desse texto e baseando-nos em nossa concepção de sujeito, podemos notar que a movimentação de fragmentos significantes se dá a partir de um interdiscurso originário da fala cotidiana. Ou seja, a memória (inconsciente) aciona fragmentos cujos sentidos parecem se fixar na barreira da língua prosaica, na qual a fala moralista de adultos se apresenta como solução linguageira para diluir a tensão.

Não é nada fácil para uma criança da periferia de São Paulo, que gosta de empinar pipas, enfrentar uma demanda de sua rival, a empresa de luz, a Eletropaulo, que promove concursos de redação com o objetivo de convencer as crianças a não empinarem pipa nas proximidades das redes elétricas. Para sair ileso do confronto, no mínimo esse improvisado escriba busca uma fraseologia emprestada aos adultos: "Esse negócio de...."; "Por favor, não...", "Confia em...."; "Antes alguém fazia, agora não faz mais...". "Hoje sou feliz". Dá para perceber que o sujeito aqui endurece seu texto com expressões que em nada refletem o seu confessado desejo: empinar 
pipa perto ou longe dos fios elétricos. Na enunciação, pressupomos um alinhamento de alteridade que vai do lugar do(a) professor(a) a um suposto leitor autorizado pela Eletropaulo, que se afina discursivamente com a condenação das pipas perto da rede elétrica.

Sendo obrigado a escrever alguma coisa, o aluno põe em jogo uma subjetividade simuladora, que aceita a cisão de seu eu criança por uma cunha de linguagem que, além de dividir, obstrui as possibilidades de manifestação de seu desejo, sufocando as contradições possíveis. O resultado é um texto em que a submissão dá o tom, em que o manejo subjetivo só é entrevisto nas passagens dos fragmentos prontos que recebe de um outro pleno, que não se deixa permear.

Diante desta demanda, se o educador tivesse alguma noção sobre os lugares discursivos que essas situações põem em jogo, talvez pudesse esvaziar um pouco o polo desse outro exigente que parece impingir à criança uma fórmula discursiva sobre a qual não se tem escolha. Talvez pudesse tratar a demanda de forma menos utilitarista, aberta a posicionamentos mais galhofeiros que, ao tomar o tema, tivesse o cuidado de apostar mais no desejo e menos na demanda do outro. Exemplo: poder-se-ia, com um debate, pôr a criança diante das seguintes posições de confronto: "eu quero empinar pipa, que se danem os fios da Eletropaulo!", "Ora, que ela tire os fios da rua, que deixe as ruas e os céus livres para as pipas e os meninos!" "Nós preferimos a diversão com as pipas à eletricidade da Eletropaulo!"

O tom aqui parece se avizinhar de uma subversão sem tamanho por parte do professor, mas é só assim que se consegue abrir algum furo nesses espessos tecidos que caracterizam o discurso dito politicamente correto, que atualmente mais cerceia a subjetividade escolar do que a conscientiza. O aluno, ao ser incitado a transgredir, pode ter seu eu dividido por uma subjetividade que vai se mover no espaço da contenda entre seu desejo de empinar pipa e 
os fios da empresa de luz. Luz ou Pipa? Como seria um mundo sem luz, sem energia elétrica, mas com liberdade para empinar pipa? Esse mundo poderia existir na fantasia? A fantasia poderia se tornar realidade, ou mesmo se transformar em projetos que pudessem prever redes elétricas subterrâneas? A fantasia talvez pudesse levar o sujeito a desafiar a empresa com proposta de criação de parques próprios para empinar pipa, com ventos e eventos especiais, com cursos e concursos, não de redação, mas de pipas - um lugar onde haveria liberdade para pipeiros e escribas.

Em nossa "pesquisa Keizo", retomamos a hipótese de que essa dificuldade de emergência de uma "subjetividade de entretexto" é um fenômeno que tanto pode ocorrer já na aquisição da fala ou no encontro (e aqui se entenda embate) de sua oralidade parental/regional com a demanda de escrita e leitura posta pelo discurso escolar. Sujeitas às singularidades parentais e a restrições do meio social, muitas crianças entrariam na escrita submetidas a um processo de subjetivação pouco afeito aos jogos linguageiros e às habilidades intertextuais, sobretudo quando diante de um outro(o discurso e os dispositivos escolares) que traz as marcas e referências que o afastam de sua comunidade mais imediata (normalmente, comunidades de origem oralista, mas, como veremos adiante e já vimos no capítulo I, cindida por uma escrita burocrática e uma oralidade pragmática).

A hipótese de que a falta de uma infância mais lúdica, mais afeita aos jogos linguísticos e manejos textuais dificulte as possibilidades subjetivas de postar-se diante do outro de uma forma mais aberta, mais brincante, que possibilite esvaziar os sentidos óbvios e imediatos para avançar diante do outro, conduziu nossa pesquisa do início ao fim, mas também mantivemos seu contraponto: a criança que traz de casa uma boa experiência linguageira, mas diante de uma escolarização que não consegue estabelecer uma ponte confiável entre sua proposta de ensino da leitura e da escrita e 
as possibilidades de engajamento dessa subjetividade de entretextos. De fato, os casos mais graves de crianças que em geral não conseguiram se alfabetizar nos anos iniciais de escolarização confirmaram sobejamente essas hipóteses. Vejamos os dados que obtivemos na pesquisa ${ }^{102}$.

\section{DIAGNÓSTICO INICIAL}

Nosso diagnóstico consistia em 13 pontos. Abaixo apresentamos um quadro distinguindo a performance de meninos e meninas em três conceitos (bom; regular e insuficiente). Esse grupo de alunos fora selecionado pela coordenação da escola e indicados pelos professores como os mais renitentes em relação à aprendizagem de leitura, todos em situação de defasagem na relação nível/série (alunos com dois, três e até quatro anos de escolarização e que ainda não dominavam a leitura).

\begin{tabular}{|c|c|c|c|c|c|c|c|}
\hline & \multirow[t]{2}{*}{ Atividade/conceitos } & \multicolumn{3}{|c|}{26 MENINOS } & \multicolumn{3}{|c|}{17 MENINAS } \\
\hline & & $\mathrm{BOM}^{103}$ & REG & INS & BOM & REG & INS \\
\hline 01 & Dizer o nome completo & 16 & 3 & 07 & 12 & 04 & 01 \\
\hline 02 & Dizer o nome completo dos pais & 10 & 07 & 09 & 09 & 05 & 03 \\
\hline 03 & Dizer a data de nascimento & 06 & 12 & 08 & 04 & 09 & 04 \\
\hline 04 & Calendário /dias da semana/mês & 07 & 05 & 14 & 07 & 05 & 05 \\
\hline 05 & $\begin{array}{l}\text { Intertextualidade (oral) } \\
\text { Identificar a narrativa a partir de } \\
\text { um fragmento significativo dado } \\
\text { pelo entrevistador }\end{array}$ & 09 & 09 & 08 & 06 & 07 & 04 \\
\hline 06 & $\begin{array}{l}\text { Contar, narrar um texto a partir de } \\
\text { sua memória. }\end{array}$ & 08 & 09 & 09 & 06 & 06 & 05 \\
\hline 07 & $\begin{array}{l}\text { Apresentar uma brincadeira oral } \\
\text { (parlenda, brinco, fórmula de } \\
\text { escolha ou outro texto na memória). }\end{array}$ & 08 & 11 & 07 & 08 & 08 & 01 \\
\hline
\end{tabular}

${ }^{102}$ Relatório Científico do projeto 2006/61047-0, entregue à FAPESP em março de 2009.

$103 \mathrm{O}$ conceito BOM era atribuído quando a criança executava sem ajuda, com muita facilidade, a atividade solicitada; REGULAR, para as performances com ajuda, dicas e apoios; INSUFICIENTE, para os alunos que, mesmo com alguma ajuda, não conseguiam (ou não sabiam) responder. 


\begin{tabular}{|c|c|c|c|c|c|c|c|}
\hline 08 & $\begin{array}{l}\text { Identificar e nomear imagens } \\
\text { impressas }\end{array}$ & 24 & $\mathbf{0 2}$ & $\mathbf{0 0}$ & 17 & 01 & 00 \\
\hline 09 & $\begin{array}{l}\text { Completar palavras a partir da } 1^{\mathrm{a}} \text {. } \\
\text { ou } 2^{\mathrm{a}} \text {.sílabas, tendo como referência } \\
\text { suas imagens (as mesmas do item } 8 \text { ) }\end{array}$ & 09 & 13 & 05 & 10 & 05 & 02 \\
\hline 10 & $\begin{array}{l}\text { Contar as sílabas dos nomes } \\
\text { oriundos das imagens nomeadas } \\
\text { (itens } 8 \text { e 9) }\end{array}$ & 09 & 12 & 05 & 10 & 5 & $\mathbf{0 2}$ \\
\hline 11 & \begin{tabular}{lccc} 
Inverter & oralmente & \multicolumn{2}{c}{ dissílabos - } \\
exemplo: & FOGO & /GO FO; \\
FADA/DA FA & & \\
\end{tabular} & $\mathbf{0 0}$ & 14 & 12 & $\mathbf{0 3}$ & 11 & 03 \\
\hline 12 & $\begin{array}{l}\text { Dizer só a primeira silaba dos } \\
\text { nomes, a partir das imagens já } \\
\text { nomeadas (item 08) }\end{array}$ & 05 & 13 & 08 & 10 & 04 & $\mathbf{0 3}$ \\
\hline 13 & $\begin{array}{l}\text { Juntar uma imagem com outra, } \\
\text { aproveitando só a primeira sílaba } \\
\text { da imagem. Abaixo, por exemplo, } \\
\text { está escrito CAFÉ (CAdeado + } \\
\text { FEijão) - }\end{array}$ & 01 & 13 & 12 & $\mathbf{0 2}$ & 10 & 04 \\
\hline \multicolumn{2}{|r|}{ TOTALIZAÇÃO } & \multicolumn{3}{|c|}{26} & \multicolumn{3}{|c|}{17} \\
\hline
\end{tabular}

A aplicação desse diagnóstico se deu individualmente, com o aluno atendido em uma pequena sala onde ficava sozinho com o pesquisador durante uns 40 minutos. Antes de iniciar o diagnóstico $o$ pesquisador entretinha a criança com conversas soltas, procurando reduzir as tensões, transformando a atividade em jogo, em brincadeira. Comentaremos a seguir todos os itens do diagnóstico.

- elementos básicos da cidadania (Itens de 01 A 04)

Os itens de 1 a 4 diagnosticaram alguns elementos fundamentais da própria identificação da criança: seu nome completo, nome de seus familiares, sua data de nascimento e sua 
concepção do tempo (conhecimento e uso de calendário). Pelos dados da tabela, notamos que esses elementos tão essenciais à cidadania ainda representavam um problema considerável. A data de nascimento, por exemplo, ainda é uma dificuldade para mais de $70 \%$ - normalmente, o entrevistador tinha que utilizar outras expressões mais típicas da fala e da infância para traduzir o termo "Data de nascimento": "quando é seu aniversário?", "em que dia você nasceu?"; ainda assim as respostas eram incompletas, fornecendo, em geral, só o dia ou só o dia e o mês. O nome completo dos familiares, muitas vezes, chegava a ser uma descoberta, com alguns alunos ficando surpresos ao saberem que seu sobrenome coincidia com o de seu pai. Aqui já é possível concluir que a solicitação desses dados se reveste de duas formas de linguagem: uma pautada pela oralidade, pela fala cotidiana familiar (quando é seu aniversário, em que dia você nasceu, quem são seus pais, onde você mora etc.) e outra já com a formalidade da escrita burocrática (Data de nascimento, filiação, endereço etc.) - aqui já temos então os indícios de um confronto entre escrita e oralidade que pode dificultar o acesso desses alunos às exigências mínimas da cidadania.

É preciso entender que por detrás desses dados há uma complexidade temática que a linguística e a psicanálise podem esclarecer: a nomeação, com tudo o que implica para a subjetividade, nome do pai, identificação, confrontos entre universo parental (muitos alunos, por exemplo, citam os apelidos do pai ou da mãe ou seus nomes caseiros: Zumbi, Duda, Pezão) e o exigido pelo outro escolar; a data de nascimento (para muitas famílias uma ocasião de ritual, de convivência, a data é um ponto de partida para a compreensão do tempo e até mesmo para que a criança se situe na família e na escola); a moradia (há situações de moradia como favelas, cortiços e abrigos sobre as quais alguns alunos preferem 
silenciar ${ }^{104}$ ); tempo (estar atento à passagem dos dias e das horas, usar calendários e agendas são atitudes mais comuns de famílias comprometidas com o universo da escrita ${ }^{105}$ ). Veremos mais adiante como a escola trata essas questões e nossas sugestões de outras possibilidades.

\section{- INTERTEXTUALIDADE E MANEJOS SILÁBICOS}

Os itens 5, 6 e 7 tinham como objetivo pesquisar a memória oral de cada aluno e suas habilidades intertextuais. Nessas atividades já obtivemos de imediato fortes indícios sobre a hipótese inicial do projeto: boa parte dos alunos (por volta de $70 \%$ de 43 diagnósticos) que ainda não dominam o alfabeto apresenta dificuldades nessas atividades.

Quanto ao item 8 - que consistia em apenas nomear objetos a partir de imagens -, com o qual se procurava aferir se havia casos de afasias severas $^{106}$ (observava-se se o aluno nomeava diretamente a imagem ou se recorreria ao contexto. Exemplo: "de cortar" por "tesoura", o que apontaria para um possível "distúrbio de similaridade"), observou-se, então, que quase todos os alunos nomeiam bem. Somente dois alunos (um menino e uma menina) apresentaram problemas parciais nessa habilidade, mas não suficientes para caracterizar claramente casos de afasia.

Nos itens de 09 a 13, que procuravam aferir as habilidades no manejo das unidades sonoras da palavra, sobretudo a destacabilidade e a reversibilidade silábicas, os alunos evidenciaram mais dificuldades

\footnotetext{
104 Trabalhando com alunos de duas favelas da Zona Oeste, na ONG, Acaia, percebíamos claramente que o endereço (favela tal, rua tal, número tal) era um grande empecilho para a reinserção social de muitos alunos. Muitas vezes, dizer o nome dos pais e o endereço poderia significar delação, posicionamento cúmplice diante da polícia, do estado.

105 Aqui também convém destacar a fala de um aluno desta mesma favela: "esse negócio de agenda é coisa de rico", dita no momento em que lhe eram exigidos agendamentos dos compromissos no estágio.

${ }^{106}$ Conforme Jakobson, 1995 (pp. 34-62).
} 
ainda do que nos itens anteriores. A reversibilidade silábica (item 11), por exemplo, para os meninos, constituiu uma dificuldade quase intransponível e atingiu $100 \%$ dos entrevistados, embora (descobrimos mais tarde) muitos deles, com ensino, aprendessem o "truque" da inversão com relativa facilidade. Também no item 13, leitura de rébus, quase todos os alunos mostraram muitas dificuldades. No entanto, tal qual para o item 11, com ensino, a maioria dominou o processo.

Comparando esses dados, já se pode evidenciar uma correlação entre os itens 5, 6 e 7 (intertextualidade e manejo de textos completos) e os de 9 a 13 (unidades silábicas), ou seja, nesta comparação já desponta a ideia de que crianças que conhecem pouco os textos completos da tradição oral e seus manejos também não dominam as unidades silábicas, e que quanto mais complicado for o caso, mais coerente é essa correlação.

Analisando as performances das meninas, podemos já reforçar a idéia de que, em geral, elas se dedicam mais aos textos da tradição oral (dominam melhor a intertextualidade, os jogos intertextuais, as parlendas e outras brincadeiras, sobretudo as que aparecem com mais frequência nos programas escolares) e, por consequência, atuam melhor com o desmonte da palavra em sílabas e em fonemas - talvez tenhamos aqui parte da explicação da razão de as meninas terem melhores performances que os meninos em leitura, como mostram as avaliações internacionais, como a do Pisa ${ }^{107}$.

107 Desde suas primeiras avaliações, o PISA vem revelando diferenças significativas no desempenho comparado entre meninos e meninas, estas se dão melhor em leitura e aqueles em matemática. Os dados podem ser conferidos no site da OCDE: http://www.oecd.org/pages/0,3417,en 3225235132235731111111 1,00.html 


\section{APÓS NOSSAS INTERVENÇÕES, O QUE CONSTATAMOS?}

Após esses diagnósticos, procuramos ministrar duas aulas semanais de reforço para uma parte desses alunos (6 meninas e 10 meninos) - a ideia era seguir o modelo da própria escola pública, que prevê aulas de reforço para alunos defasados. Os atendimentos eram individualizados ou em pequenos grupos, sempre tendo como referência o diagnóstico inicial. Vejamos, após quatro meses de atuação, a relação entre DIAGNÓSTICO INICIAL E DESEMPENHO FINAL:

\begin{tabular}{|c|c|c|c|c|}
\hline & Aluno & Série & DIAGNÓSTICO INICIAL & DESEMPENHO FINAL \\
\hline \multicolumn{5}{|c|}{ MENINAS } \\
\hline 01 & $\overline{\mathrm{EV}}$ & $4^{\mathrm{a}}$. & $\begin{array}{l}\text { Dificuldades com todos os itens da } \\
\text { oralidade, inclusive dificuldade em } \\
\text { nomear imagens. }\end{array}$ & $\begin{array}{l}\text { Avanço insignificante. } \\
\text { Aprendeu algumas parlendas, } \\
\text { mas quase não as mantinha na } \\
\text { memória. }\end{array}$ \\
\hline 02 & $\mathrm{LN}$ & $3^{\mathrm{a}}$ & $\begin{array}{l}\text { Avaliação prejudicada pela timidez, } \\
\text { mas ficou evidente a imensa } \\
\text { dificuldade para retomar textos da } \\
\text { infância. Com idade mais avançada } \\
(13 \text { anos), já apresentava maior } \\
\text { propensão às músicas sertanejas } \\
\text { amorosas do que aos textos da } \\
\text { tradição oral }\end{array}$ & $\begin{array}{l}\text { Pequeno avanço tanto na } \\
\text { oralidade como na escrita. }\end{array}$ \\
\hline 03 & NAT & $2^{a}$ & $\begin{array}{l}\text { Dominava parcialmente os itens do } \\
\text { diagnóstico (sabia algumas } \\
\text { parlendas e cantigas de memória). }\end{array}$ & \begin{tabular}{lrr} 
Lia sem & \multicolumn{2}{c}{ subvocalização, } \\
embora & ainda & com \\
dificuldades & nas & sílabas \\
complexas. & & \\
\end{tabular} \\
\hline 04 & BR & $3^{\mathrm{a}}$. & Possuía bom repertório textual. & $\begin{array}{l}\text { Avançou rapidamente na } \\
\text { leitura, mas com oscilações } \\
\text { em função de suas } \\
\text { dificuldades familiares. }\end{array}$ \\
\hline 05 & IN & $2^{\mathrm{a}}$ & $\begin{array}{l}\text { Bom desempenho nas atividades } \\
\text { orais, apesar da timidez inicial. }\end{array}$ & $\begin{array}{l}\text { Avanço muito significativo. } \\
\text { Ao sair, já estava lendo. }\end{array}$ \\
\hline 06 & LAR & $2^{a}$ & $\begin{array}{l}\text { Bom desempenho nas atividades } \\
\text { orais (em quase todos os itens). }\end{array}$ & $\begin{array}{l}\text { Avanço muito significativo. } \\
\text { Aprendeu a ler e atribuir } \\
\text { sentido ao texto. }\end{array}$ \\
\hline \multicolumn{5}{|c|}{ MENINOS } \\
\hline 01 & GU & $4^{\mathrm{a}}$. & $\begin{array}{l}\text { Dificuldade com narrativas e com a } \\
\text { memorização de parlendas e } \\
\text { cantigas. }\end{array}$ & $\begin{array}{l}\text { Avançou pouco no domínio } \\
\text { das sílabas complexas. Bom } \\
\text { desempenho com rébus e em } \\
\text { outras atividades orais. }\end{array}$ \\
\hline 02 & GA & $4^{\mathrm{a}}$. & Dificuldades em quase todos os & Experimentou avanço não \\
\hline
\end{tabular}




\begin{tabular}{|c|c|c|c|c|}
\hline & & & itens do diagnóstico. & $\begin{array}{l}\text { muito significativo; no final, } \\
\text { ainda tinha dificuldade para } \\
\text { ler sem vocalizar. }\end{array}$ \\
\hline 03 & VI & $4^{\mathrm{a}}$. & $\begin{array}{l}\text { Dificuldades em quase todos os } \\
\text { itens do diagnóstico, sobretudo nos } \\
\text { que exigiam memorização. }\end{array}$ & $\begin{array}{l}\text { Experimentou um avanço } \\
\text { extraordinário. Passou a } \\
\text { gostar de jogar e brincar com } \\
\text { textos orais. No final do } \\
\text { atendimento já lia, mas ainda } \\
\text { com algumas dificuldades. }\end{array}$ \\
\hline 04 & JR & $4^{\mathrm{a}}$. & $\begin{array}{l}\text { Dificuldades com quase todos os } \\
\text { itens do diagnóstico. }\end{array}$ & $\begin{array}{lr}\text { Experimentou } & \text { pequeno } \\
\text { avanço. } & \text { Atendimento } \\
\text { prejudicado em razão das } \\
\text { faltas. }\end{array}$ \\
\hline 05 & $\mathrm{~W}$ & $4^{a}$. & $\begin{array}{l}\text { Dificuldades com quase todos os } \\
\text { itens do diagnóstico. Vocaliza } \\
\text { partes do texto, mas sem atribuição } \\
\text { de sentido. }\end{array}$ & $\begin{array}{l}\text { Experimentou um } r \text { bom } \\
\text { avanço em leitura. Já lia } \\
\text { atribuindo sentido, embora } \\
\text { ainda não com o fluxo } \\
\text { desejável. }\end{array}$ \\
\hline 06 & $\mathrm{AL}$ & $4^{\mathrm{a}}$. & $\begin{array}{l}\text { Apresentou bom desempenho em } \\
\text { quase todos os itens do diagnóstico. } \\
\text { Já reconhecia as letras, mas tinha } \\
\text { dificuldades com as sílabas } \\
\text { complexas. }\end{array}$ & $\begin{array}{l}\text { Experimentou alguns avanços } \\
\text { no domínio das sílabas } \\
\text { complexas. Seu atendimento } \\
\text { foi prejudicado por faltas e } \\
\text { descontinuidades. }\end{array}$ \\
\hline 07 & VH & $3^{\mathrm{a}}$ & $\begin{array}{l}\text { Desempenho razoável nas } \\
\text { atividades orais. Apresentava uma } \\
\text { singularidade interessante: } \\
\text { conseguia verbalizar o texto, mas } \\
\text { não compreendia o sentido. }\end{array}$ & $\begin{array}{l}\text { Passou a ler de forma mais } \\
\text { expressiva, atribuindo sentido } \\
\text { e usando melhor a memória } \\
\text { no momento de parafrasear } \\
\text { um texto lido. }\end{array}$ \\
\hline 08 & $\mathrm{PE}$ & $3^{\mathrm{a}}$. & $\begin{array}{l}\text { Dificuldades em quase todos os } \\
\text { itens do diagnóstico inicial. }\end{array}$ & $\begin{array}{l}\text { Pequenos avanços na } \\
\text { progressão de narrativas. } \\
\text { Ainda permaneceu com } \\
\text { grandes dificuldades no } \\
\text { domínio de narrativas orais. }\end{array}$ \\
\hline 09 & VR & $3^{\mathrm{a}}$. & $\begin{array}{l}\text { Boa memória textual, bom } \\
\text { desempenho com quase todos os } \\
\text { itens do diagnóstico. }\end{array}$ & $\begin{array}{l}\text { Avançou na leitura e na } \\
\text { compreensão de texto, mas } \\
\text { ainda apresentava algumas } \\
\text { dificuldades com as sílabas } \\
\text { complexas. }\end{array}$ \\
\hline 10 & $\mathrm{RD}$ & $2^{\mathrm{a}}$ & $\begin{array}{l}\text { Dificuldades em quase todos os } \\
\text { itens do diagnóstico. }\end{array}$ & $\begin{array}{l}\text { Pequenos avanços na leitura } \\
\text { de rébus. Ainda permaneceu } \\
\text { com grandes dificuldades no } \\
\text { domínio de narrativas. }\end{array}$ \\
\hline
\end{tabular}

Como se pode ver no quadro abaixo, não há nenhum caso de aluno que tendo apresentado um repertório oral interessante (sinal +) no diagnóstico inicial, não tenha experimentado algum avanço (sinais + ou +-) em sua leitura, na situação final. Os dois casos mais complexos, que ficaram estagnados mesmo a partir dos atendimentos, apresentaram uma situação inicial bem 
comprometedora (sinal -) em termos de domínio dos itens do diagnóstico.

SINOPSE DA SITUAÇÃO:

\begin{tabular}{|c|c|c|c|}
\hline Inicial & Final & Meninas & Meninos \\
\hline- & - & 1 & 1 \\
\hline- & +- & 1 & 4 \\
\hline- & + & 0 & 2 \\
\hline+- & + & 1 & 3 \\
\hline+ & + & 3 & 0 \\
\hline
\end{tabular}

Reforça-se aqui, então, a seguinte hipótese: alunos em cujas memórias não se detectam, com facilidade, manejos intertextuais e habilidades linguageiras tendem a experimentar problemas sérios durante a escolarização da leitura e da escrita. Poderíamos também pensar em um contraponto que nos levaria a uma outra hipótese: tais alunos experimentam dificuldades com o diagnóstico oral justamente porque não aprenderam a ler, já que a escrita poderia ser uma facilitadora de tais habilidades ${ }^{108}$. Com o objetivo de reforçar ainda mais a primeira hipótese, nosso projeto efetivou mais uma fase durante a qual procuramos subsidiar duas séries iniciais do fundamental I, sustentando um programa de ensino baseado em nossos diagnósticos, ou seja, cada item do diagnóstico abriu um

\footnotetext{
108 Esse contraponto seria depreendido das discussões do capítulo I, pois boa parte dos autores que apoiam a tese da "grande virada" afirma que a escrita permitiu destacabilidade aos elementos menores da fala, a sílaba e o fonema passando a ser mais facilmente depreensíveis, assim como lexemas e gramemas. Talvez essa conclusão seja parte do equívoco apontado por nós nessas concepções: como esses autores enxergam as comunidades de origem oral (seja primária ou secundária, como indicou Ong) de forma homogênea, imaginam sempre o falante prosaico sob efeito das construções formulares do cotidiano, mas não imaginam que essa escuta possa ser diferente, que essa pregnância possa ser cindida por subjetividades que percebem o manejo dos recursos orais que implicam a função poética.
} 
tópico curricular. Ao longo do ano, procuramos observar também a dinâmica de renitência dos alunos que tenderiam a terminar o ano sem o domínio completo do alfabeto e da leitura. Antes de entrar nessa segunda fase, cabe aqui uma distinção:

\section{FAÇAMOS UMA DIFERENÇA ENTRE NOSSA HIPÓTESE E AS DAS DÉCADAS DE SESSENTA E SETENTA.}

É importante ressaltar que essa nossa hipótese difere substancialmente das que surgiram nas décadas de sessenta e setenta, que acabaram rendendo ao ensino a famosa hipótese da Mãe inadequada ou da teoria do déficit e que gerou a educação compensatória ${ }^{109}$. Tais teorias foram ruidosamente refutadas por muitos sociolínguistas e psicólogos cognitivistas, embora, de uma forma ou de outra, o elemento motivador dessas pesquisas e até mesmo os equívocos de suas transposições para o campo do ensino ainda mantenham fortes ecos na educação contemporânea. Ainda que hoje se reformulem em questões difusas, que tanto confundem os educadores: como podemos entender a influência da linguagem que a criança traz da família diante da escolarização? A partir dessa linguagem ou da bagagem que a criança traz é possível ampliar o conhecimento até os níveis mais abstratos? É mesmo possível ensinar a criança pobre e desassistida cuja hiperatividade vai além do normal? Há confrontos entre o ensino da escrita e a concepção de escrita que a criança traz de seu meio?

Nossa pesquisa procura não só enfrentar teoricamente essas questões, mas também, a partir de algumas evidências, apontar

\footnotetext{
109 Não pretendo fazer este cotejo teórico aqui, mas remeto o leitor para duas obras: uma ampla coletânea organizada por Patto (1997), em cujas páginas se podem encontrar inclusive um artigo de Bernstein, um dos autores a quem foi atribuído estabelecer a teoria do déficit e o rótulo da "mãe inadequada" e o artigo de Soares (1989), que explana a contenda entre Bernstein e Labov. Outro autor que se firmou decidindo a contenda contra a simples atribuição de culpa a uma família homogênea foi Lahire (1997).
} 
elementos para um currículo que possa repor, se for o caso, um certo repertório de textos orais e de jogos da tradição infantil brasileira e mostrar que eles são essenciais na constituição de uma ambiência de linguagem que de fato coloque a relação entre leitura e oralidade em evidência. Nossa preocupação não se centra em déficits de fala ou de linguagem ou mesmo na idéia de "código restrito" por oposição a "código elaborado", como as de Bernstein (1997 pp.165,166).

O que constatamos permite-nos afirmar que tanto o meio como a família e os educadores do ensino infantil e das séries iniciais do fundamental, em geral presos a uma oralidade terciária ou às malhas da centralidade da escrita e das teorias que também nela se centraram, não conseguem dotar essas crianças de um repertório de textos de origem oral, ou mesmo daqueles oriundos da própria escrita, que sejam suficientes para que uma subjetividade de entretextos faça aí seus jogos intertextuais e seus manejos linguageiros. Como afirmamos, tais manejos são responsáveis por uma apreensão mais dinâmica da palavra e do texto, que facilita consideravelmente a entrada na escrita. Como vimos nos capítulos anteriores, nosso conceito de texto e de subjetividade aqui implica relações mais complexas que incluem, por exemplo, movimentos de identificação, de transferência, enfim, sutis jogos de alteridade.

Essa "falta discursiva" que aqui detectamos também vem sendo percebida pelos próprios sistemas de ensino. Por exemplo, quando o governo brasileiro resolve - seguindo os passos de boa parte dos países desenvolvidos - ampliar o ensino fundamental para nove anos, trazendo a criança mais cedo (seis anos) para a educação obrigatória, de algum modo está procurando garantir que a escola se antecipe à família, ou seja, que forneça alguma base mais cedo, como se pode ver nos documentos do governo que implementam essa novidade:

Outro fator importante para a inclusão das crianças de seis anos na instituição escolar deve-se aos resultados 
demonstrarem que, quando crianças ingressam na instituição escolar antes dos sete anos de idade apresentam, em sua maioria, resultados superiores em relação àquelas que ingressam somente aos sete anos. A exemplo desses estudos, podemos citar o Sistema Nacional de Avaliação da Educação Básica (Saeb) 2003. Tal sistema demonstra que crianças com histórico de experiência na pré-escola obtiveram maiores médias de proficiência em leitura: vinte pontos a mais nos resultados dos testes de leitura. (Brasília, 2006 p. 5,6)

O mesmo acontece quando clamamos pela universalização do ensino infantil - quase sempre se entende que este venha ocupar um lugar estratégico na preparação das bases para o ensino fundamental e que a sistematização desses ciclos é ainda mais importante para as crianças de meios desfavorecidos, pois acaba funcionando como um complemento das funções parentais ${ }^{110}$. Nas pesquisas nacionais e internacionais construiu-se um amplo consenso sobre os cuidados que as famílias desfavorecidas exigem dos sistemas educacionais hoje não é possível a um sistema escolar público organizar seus currículos e programas sem levar em conta as diferenças de classe produzidas pelas dinâmicas parentais e comunitárias, como já atestava Houston (1997) para a década de setenta.

Nossa hipótese e nossa pesquisa, diferentemente das que buscavam o déficit linguístico, focam a presença/ausência de textos completos da tradição oral e o manejo dos ludismos linguísticos típicos da infância em dois pólos, tanto no da família-comunidade (ou

110 A partir de estudos das pesquisas realizadas em diversos continentes, os Parâmetros Nacionais de Qualidade para a Educação Infantil (Brasil, 2006), mostra com clareza a importância dessa complementaridade, embora alerte para a importância da organização mais qualitativa desse ciclo para não figurar apenas como uma espécie de substituto das funções familiares mais elementares (ligadas mais ao cuidar do que ao educar). 
seja, que repertório o aluno traz), como no da escola (se o programa escolar leva em conta esse repertório e suas possíveis faltas).

Embora a parte mais qualitativa e intensiva dessa primeira fase de nossa pesquisa tenha contado com apenas dezesseis alunos, entre os quarenta e três diagnosticados, pudemos perceber alguns pontos que chamam a atenção, sejam eles entendidos como carência ou não:

\section{- MUITAS DIFICULDADES COM AS NARRATIVAS}

Os alunos que não conseguiam narrar, que narravam fragmentariamente, como são os casos de EV e RD, avançaram muito pouco. Como são apenas dois, pudemos perceber claramente um histórico familiar muito complexo (a família de RD perdeu sua guarda e ele foi morar em um abrigo; EV mora com as tias, pois sua família vivia no nordeste). Em geral a habilidade narrativa de quase todos esses alunos apresentava-se bastante fragmentária, mesmo quando narravam textos muitos simples, tematicamente bem demarcados, como "Os três porquinhos". No caso de RD (oito anos, segunda série), constatamos, com clareza, como a sua narrativa, além de fragmentada, é permeada por hiatos e lapsos que comprometem seu envolvimento subjetivo na construção da coerência. Notamos que, ao dar oportunidades para que essa criança exercitasse a sua narratividade, também Ihe estávamos proporcionando oportunidades de lidar um pouco com os acontecimentos que marcaram a sua ida para o abrigo (presenciava o abuso sexual de sua irmã dentro de sua casa, por homens desconhecidos, que sua mãe trazia da rua). Vejamos uma das sessões em que $\mathrm{R}$ tenta narrar, com apoio do pesquisador, o conto "Os três porquinhos":

1. $\boldsymbol{P}$ - Eu vou falar primeiro, depois você repete! $O$ primeiro porquinho fez sua casa de palha, o segundo porquinho 
2. $\quad \boldsymbol{R}-$ fez a casa de madela.

3. $\boldsymbol{P}-O$ terceiro porquinho....

4. $\boldsymbol{R}-$ Fez a casa di..di...di...ããã....

5. $P$ - Começa com ti...

6. $\quad \boldsymbol{R}$ - di tijolo (diz com alegria)

7. $\boldsymbol{P}$ - Agora, fala tudo de novo, você!

8. $\quad \boldsymbol{R}$ - (dando uma arrancada) ..o primelo poquinho fez a casa de palha... depois o oto poquinho fez a casa de madela...e...depois fez a casa di... di... di....di...a casa di...(para, resolve retomar tudo)...o primelo poquinho fez a casa di palha, depois segundo foi...primelo....casa diiiii...palha...não!.o oto poquinho fez a casa..di madeia e o oto pouquinho fez a casa diiiiii.... tijolo! (olha para o entrevistador como se tivesse terminado a história).

9. $\boldsymbol{P}-E$ quem apareceu?!

10. $\boldsymbol{R}$ - O lobo mau.

11. $\boldsymbol{P}$ - O que que ele feeez?

12. $\boldsymbol{R}$ - Assopô todas as casas.

13. $\boldsymbol{P}$ - Todas as casas?! Fala pra mim, qual casa que ele assoprou primeiro?

14. $\boldsymbol{R}-A$ de palha...

15. $\boldsymbol{P}$ - E o que aconteceu?

16. $\boldsymbol{R}$ - Correu!

17. $\boldsymbol{P}$ - Quem correu?

18. $\boldsymbol{R}-$ O homi diiiiii.....tijolo!

19. $\boldsymbol{P}-O$ homem de tijolo?!

20. $\boldsymbol{R}$ - Não, o home...o lobo mau!.... sopo toda a casa... sopo toda a casa... depois que ele assopo...

21. $\boldsymbol{P}$ - Ele assoprou toda a casa?!

22. $\boldsymbol{R}-$ Assopô!

23. $\boldsymbol{P}$ - Mas você estava me dizendo que o lobo mau assoprou a casa de palha....

24. $\boldsymbol{R}$ - di palha...

25. $\boldsymbol{P}$ - E a aí o que aconteceu...o porquinho saiu correndo.... pra onde ele foi?

26. $\boldsymbol{R}$ - foi pra ota casa di tijolo.

27. $\boldsymbol{P}$ - O porquinho da casa de palha foi pra casa de tijolo?!

28. $\boldsymbol{R}$ - (bocejando fundamente).... di madela!

29. $\boldsymbol{P}-E$ depois?

30. $\boldsymbol{R}-E$ depois assopô de novo.

31. $\boldsymbol{P}-E$ o que aconteceu?

32. $\boldsymbol{R}$ - ...e depois vuo pra ota casa di di di tijolo...e depois nunca assopô.... fuuuuu (assopra).

33. $\boldsymbol{P}$ - Ele tentou entrar pela....

34. $\boldsymbol{R}$ - Chaminé!

35. $\boldsymbol{P}-$ E o que que aconteceu?

36. $\boldsymbol{R}$ - (inaudível)...colocô fogo aqui... (aponta para a perna)...do rabo dele.... (bate com a costa da mão na palma da outra indicando saída repentina)...voi pra ota casa. 
Comparando essa nossa análise com as pesquisas sociolinguísticas das décadas de 60 e 70, é possível observar que mudamos completamente o foco. Não estamos preocupados com o déficit linguístico, mas com a própria habilidade narrativa e com a posição subjetiva do aluno no ato de narrar. Percebemos esse sujeito cindido entre o fluxo da narrativa e suas perturbações de origem afetivas, marcando os hiatos, pausas e esquecimentos. Analisando esses e outros fragmentos, fica claro que $\mathrm{R}$ sabe todo o script dos três porquinhos, no entanto, ao narrar, um outro fluxo discursivo invade a narrativa, corta-a, efetivando lapsos e esquecimentos. 0 que ele parece manter sempre é a teatralidade do ato de narrar, desde prolongamentos prosódicos até a gesticulação, contudo o atravessamento de uma outra camada significante parece incidir de tal forma sobre o fluxo da narrativa que até mesmo essa teatralidade se submete. Um exemplo claro é o turno 16, quando $\mathrm{R}$ introduz um verbo sem sujeito, Correu! e diante da pergunta do pesquisador (17), Quem correu?, responde O homi diiii...tijolo! (18)". Mesmo quando tenta corrigir, ainda repete a palavra intrometida, Não, o home...o lobo mau! Sopô toda a casa...Sopô toda a casa...depois ele assopô...(20). Outro ponto interessante é seu salto para o clímax da história e para os momentos que permitem maior teatralidade, por exemplo, o ato de assoprar.

Essa dificuldade de conduzir a história, enredando seus motivos centrais e de retardamento, não é só de $R$, é mais ou menos comum. As crianças que possuem maiores dificuldades com narrativas, quase sempre encurtam demais a história, saltando o mais rápido possível para seu clímax e para a sua fórmula de finalização: "E viveram felizes para sempre". $R$, por exemplo, em uma das gravações, no meio da história, adiantou um "feliz pa sempe, ponto cabô!" - como se quisesse livrar-se logo do incômodo de narrar. Talvez esse encurtamento não deixe de ser uma evitação da angústia, pois por mais que a criança goste desta ou daquela história, narrá-la implica sempre um comprometimento subjetivo mais denso, que enreda elementos de um simbólico ainda não dominado. Tais elementos, ao alimentar o fluxo narrativo, ameaçam trazer à superfície significantes que se implicariam na narrativa, usando-a como um vírus usa nossas células, ou 
seja, inoculando sua virulência para controlar a própria reprodução, daí que para evitar essa angústia melhor mesmo será pular para o "feliz pá sempe".

Esta nossa reflexão mostra como é importante permitir às crianças essa possibilidade de se experimentar como narrador; em outras palavras, dar-Ihe uma matriz textual para que sobre ela, como em um sonho, o aluno deixe seu sujeito entretecer suas próprias verdades. É o caso, por exemplo, da produção de texto que colhemos em uma outra pesquisa (Belintane, 2006c) realizada em uma escola cujo currículo tem a preocupação de dotar as crianças com um bom repertório oral e de também desconstrui-lo na idade apropriada - por exemplo, os contos de fadas e fábulas são retomados no quinto ano (dez anos), mas sob o crivo da paródia. Vejamos este exemplo como contraponto à consigna da Eletropaulo (do "Menino da pipa):

PARÓDIA DO CONTO DE FADAS "Chapeuzinho Vermelho", a partir de uma consigna que propunha a parodização do conhecido conto. Trata-se de uma turma da antiga quarta-série (alunos com dez anos).

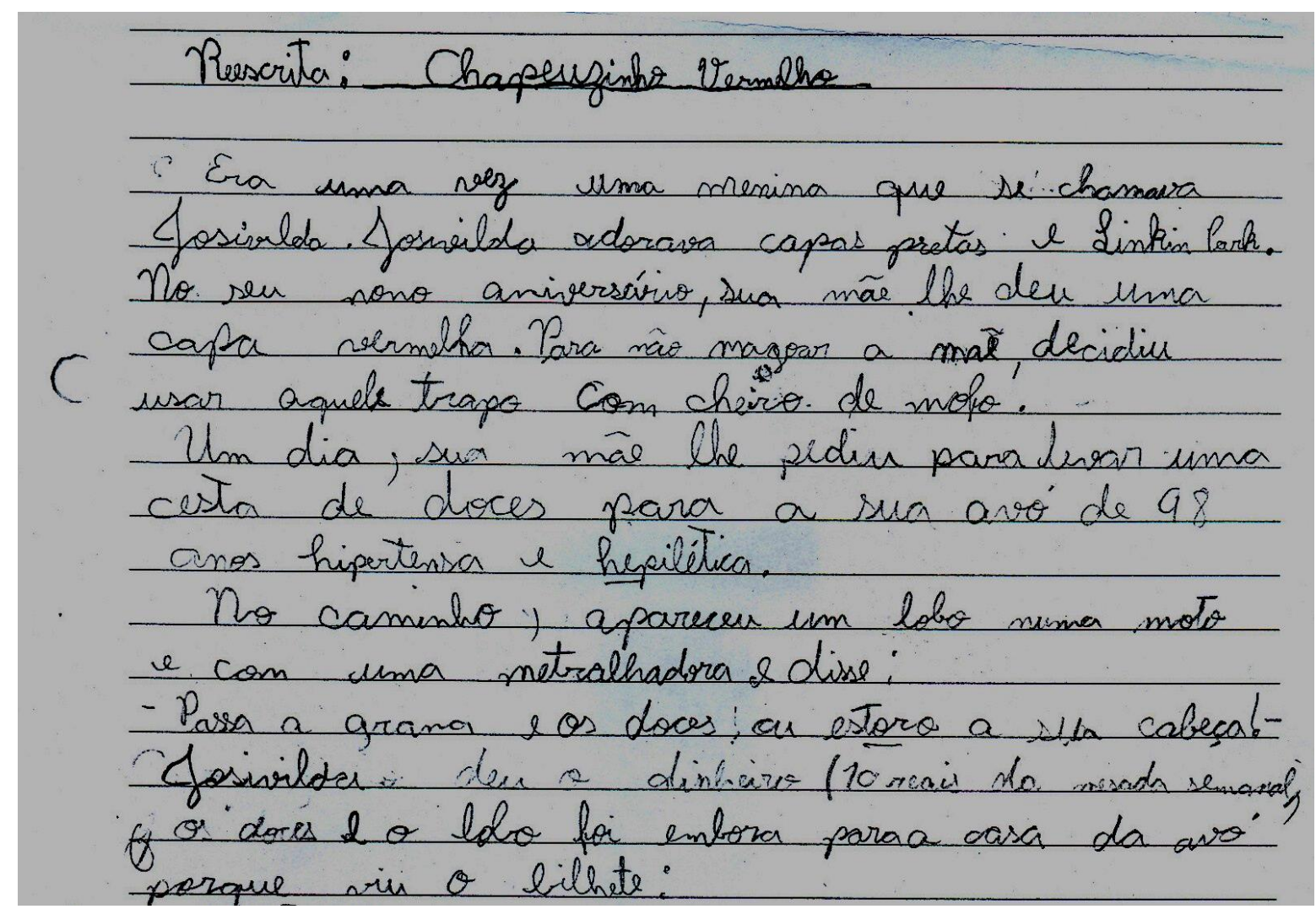



resis que tumba escondido na miexa e comprou un brigaderio para sues ovó.

Quando chegon na casa de sua anó, besteu na porta edisse:

- Vow, sou us, fosiolda, sua notionsa.

Ea ano responden.

- Clavo queride, entre for fareg - dise a avó com una roy berm nouca.

(Cosivilda estranhor a ano' \& perauntos:

- Vovó, pra que esses ohos táo grandes?

- Prate ser mellor, minha neturasa.

- E pra que esse Nariz tấ grande?

- Pro ienter tes perlume melhor, minha nitinha.

- E pra que essas orethas tà grandes?

- Pra te ounir mellor, minta netualia.

- E pra que essa broca tão gronde?

- Pra coner ten brigadeiro melhor! -

Nese monsento Gosivildos peacer ses celucar e ligon ro corador ane chigon, pigar a arma. (

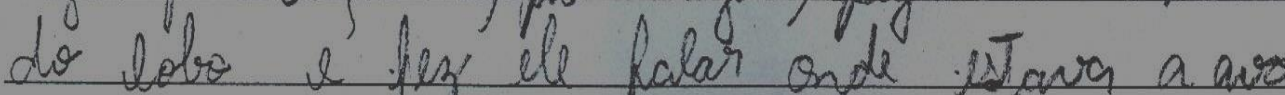
de fosiribn.

214 


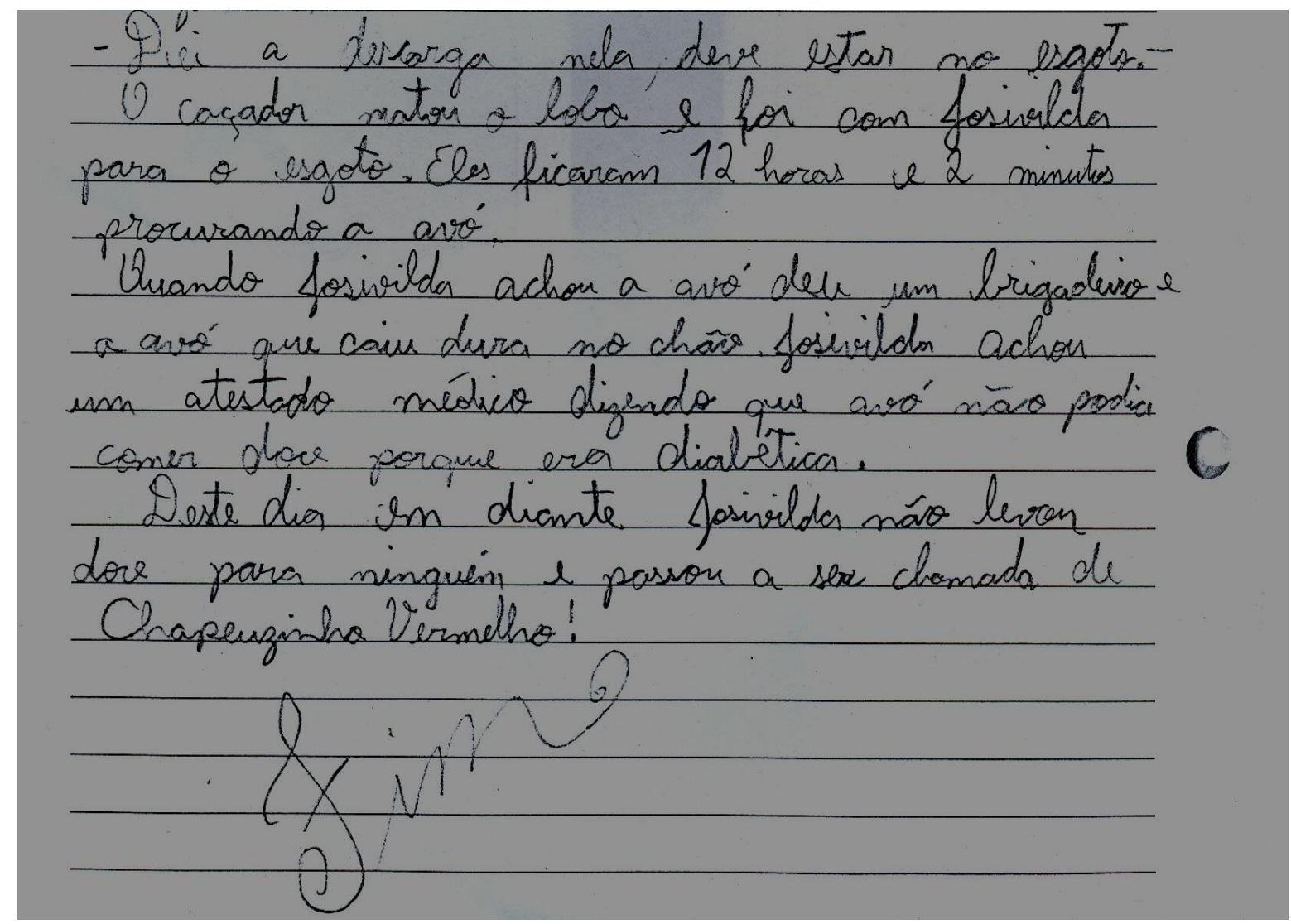

Não pretendemos analisar o texto integralmente, mas é notável aí uma subjetividade solta, pontuando por entre o texto da Chapeuzinho Vermelho com muita tranquilidade, destilando sua ironia, seu senso de humor. A intenção autoral de fazer rir, de exercer destemidamente a paródia, dá ao texto traços claros de autoria. Ao terminar de ler o texto, tal qual ocorre com um grande autor, temos vontade de saber quem é a criança, como se porta na escola etc. O interessante é que, se comparado ao texto do Menino das Pipas, podemos dizer que o jogo intertextual não é tão diferente, pois este também lança mão do intertexto do cotidiano, encaixa expressões de adultos, sobretudo da área da saúde (hipertensão, epilepsia, diabete). Mas o faz a partir de uma posição não moralista, dotada de uma verve paródica, humorista.

Este caso encorajou-nos a elaborar uma pesquisa mais sistemática sobre os efeitos parafrásticos e paródicos alcançados com consignas bem definidas. (Belintane, 2009 prelo) 


\section{- INTERTEXTUALIDADE}

As questões do item $A$, a intertextualidade e as narrações funcionam razoavelmente com as crianças de escola pública em geral, mas só quando se acionam textos bem conhecidos, oriundos sobretudo da televisão e do cinema. O problema é que o repertório é quase sempre insuficiente para o ciclo e a idade. Os contos de fada que os alunos mais conhecem são os que, normalmente, estão presentes nos programas das séries iniciais (Os três porquinhos, Branca de Neve, A bela adormecida, Cinderela e Chapeuzinho Vermelho) e, também, "coincidentemente", são os mais visados pela indústria da cultura de massa (filmes, programas de TV, CDs de contação de histórias e outros). Aqui parece que tocamos na falta de conhecimento de educadores e pais, que restringem esse repertório ao que o cinema e a televisão divulgam, sobretudo às adaptações dos Estudos Disney, o que não deixa de ser uma espécie de negação do próprio ato de contar, da memória e da oralidade em si. Nessa massificação saem perdendo os contos e mitos brasileiros, esses mesmos que já alimentaram o imaginário de muitos escritores, sobretudo os modernistas. Henriqueta Lisboa, no prefácio de sua coletânea, Literatura Oral para a Infância e Juventude, mostra que justamente por se compor de três correntes distintas, europeia (principalmente ibérica), ameríndia e africana... nosso folclore além de conter a mesma essência universal dos demais, "reúne os mais diversos matizes da imaginação, surpreendentes achados da inteligência e intenções civilizadoras..." (p.13) Para nós, tais narrativas remexem mais efetivamente com a língua, com os temas nacionais, recortando, muitas vezes, elementos da fauna e da flora, além de fazer referências históricas e geográficas que perfazem um imaginário vivo e interessante. Uma folheada rápida nessa coletânea já nos dá uma idéia de uma fauna que a criança brasileira pode reconhecer: beija-flor, quero-quero, avestruz, saracura, onça, urubu 
e muitos outros, além de personagens folclóricos conhecidos, como o Curupira, O Caboclo D'água, O Negrinho do Pastoreio, A Caipora, A velha Gulosa (A Ceiuci, que aparece em Macunaíma, de Mario de Andrade) e muitos outros.

Nas entrevistas, procurávamos saber se o aluno trazia outras histórias, causos ou outras narrativas diferentes desse repertório já bastante escolarizado e excessivamente explorado pelas mídias. Surgiram algumas, mas quase sempre em pequenos fragmentos; entre elas, por exemplo, emergiram a figura do lobisomem, a do saci, da mula-sem-cabeça e alguns causos de assombração - em geral ouvidas no ambiente familiar. A escuta dos professores, quase sempre, atribui pouca importância a esses fragmentos, o que constitui um erro, pois em geral tais temas poderiam ser expandidos e ir ao encontro de outros textos oriundos dos livros.

Fica também evidente nesse repertório escolar um descompasso entre a idade e o universo da narrativa, pois no momento em que o aluno deveria iniciar a desconstrução ${ }^{111}$ desses textos para ingressar em outros, ainda nem sequer os assimilou.

A intertextualidade, que é um alcance mais amplo dos efeitos metafóricos e metonímicos do inconsciente linguageiro, é uma habilidade que não depende de um sujeito ativo, centralizado, mas de um efeito intertextual e discursivo, de associações repentinas que podem ser bem aproveitadas tanto na leitura como na produção textual. Tais associações não seriam tão diferentes das intromissões significantes que constatamos na narrativa de RD, que o impediam de narrar. Como vimos, no capítulo I, crianças de dois anos são capazes de jogos intertextuais inusitados que irrompem de sua memória. Ou

\footnotetext{
111 Em 2009 (prelo) comparamos duas produções textuais, uma a partir de uma paródia desconstrutiva de um conto de fadas, outra a partir do mesmo tema (desobediência paterna), mas a partir de uma consigna simples, baseada mais na percepção cotidiana do tema do que nas abordagens literárias da tradição infantil. Constatamos que, na quarta série, o aluno que já dispõe de um repertório oral amplo, que pode ser parodiado, tem condições de desconstruir essas histórias e aproveitar o arcabouço do gênero para construir narrativas satíricas ou mesmo para jogos intertextuais mais amplos.
} 
seja, o texto estava lá, "in absentia" como diria Saussure, disponível para um link fortuito. No caso de $\mathrm{R}$ e outros alunos da escola pública, em lugar do texto seus sintomas parecem pôr ali emergências de histórias mal contadas, mal formuladas - como diria Lacan em seus primórdios do Função e Campo da Fala e da Linguagem: ...capítulo de minha história que é marcado por um branco ou ocupado por uma mentira: é o capítulo censurado (1998, p. 260), que pode ser inscrito - como é o caso - em intromissões significantes por sobre outras escritas, no caso, contos da tradição oral.

Em nossa perspectiva, tal habilidade é uma das mais importantes no processo de compreensão e de interpretação de textos. Sua expansão abre oportunidades para que um sujeito de entre-textos se desloque no processo da leitura, permitindo arejamentos, hiatos, espaços de reflexão leitora. Nos programas escolares e nos livros didáticos, como vimos, em geral não há um planejamento que forneça aos alunos uma ambiência propícia a estas habilidades.

- LUdismos linguísticos Visando os Níveis MENORES (FONEMAS, LETRAS, SÍLABAS, PALAVRAS)

As brincadeiras com palavras, os também chamados ludismos linguísticos - alguns dos quais foram utilizados no diagnóstico inicial (itens de 9 a 13 de nosso quadro) e muitos outros fizeram a base dos atendimentos (trava-línguas, fórmulas de escolha, réplicas e outros que detalharemos mais adiante) - ainda soam para essas crianças (e também para seus professores) como novidades ou como um tipo de texto com o qual eles já brincaram (ou usam no ensino), mas cujo domínio ou mesmo envolvimento é ainda bastante precário.

Também é possível perceber que boa parte desses alunos evidencia uma resistência significativa diante das exigências da escrita. Se por um lado conseguiam reaprender os jogos da oralidade 
e até mesmo chegavam a brincar descontraidamente com palavras e com textos, quase sempre, na hora de encarar o alfabeto e a leitura, traziam muitas reclamações e resistências. Alguns deram bons saltos qualitativos quando estabeleceram com os profissionais que os atendiam uma relação de confiança e, quase sempre, isso se dava por meio de brincadeiras e jogos com textos da oralidade.

As exigências da escrita, sobretudo no que tange ao domínio do corpo (permanecer sentado, em silêncio, concentrado em atividades sobre um livro ou caderno), parecem ser o ponto de contenda mais significativo que observamos. Nessa contraposição, as atividades orais possuem a vantagem de também permitir expressões com o corpo, no entanto, devido à expectativa de escolarização, o aluno já antecipa certa resistência às brincadeiras, por mais espontâneas que elas sejam, já que espera ali perguntas ou atividades de escrita diante das quais terá que suportar alguma angústia. Então, não é raro toparmos com desculpas, com timidez simulada, enfim, com todo tipo de trejeitos que preparam a evasão, a fuga. Entretanto, aqui entram a persistência do professor e sua habilidade na condução dos jogos. Vejamos alguns exemplos:

\section{a) Leitura de imagem, com corte acrofônico112 (dizendo apenas a primeira sílaba)}

Trata-se de uma atividade muito simples, em que o aluno é instado primeiro a nomear as imagens, depois relê-las, mas pronunciando apenas a sílaba inicial. Esse tipo de atividade é bastante utilizado por defensores das metodologias fônicas e

\footnotetext{
112 Do grego akros (altura, extremidade) - phõné (som, voz) - Esse princípio, que está na história da escrita, consiste no reaproveitamento de uma sílaba inicial pra compor outras palavras. Esse mesmo princípio é utilizado na leitura de rébus, ou seja, imagem valendo como som, no caso, primeira sílaba do nome do objeto representado pela imagem, como mostra Février: Le rébus conduit presque inévitablement à l'écriture phonétique (...). C'est ainsi que gin (être fidèle) est devenu gi; mun (nom) est passé a mu (...)" (1948, p.107).
} 
silábicas, embora aqui nosso viés teórico seja muito diferente: enquanto para eles é a segmentação que conta, o domínio da silabação em si, para nós é o corte e os restos, com tudo o que isso implica quando levamos em conta o inconsciente. Um exemplo é o caso do aluno Tiago, que narraremos mais adiante.

Notamos que boa parte dos alunos experimenta grandes dificuldades diante dessa operação. Em geral a pregnância da imagem já induz seu nome de forma direta, sem espaços para corte. Para alguns alunos, como R ( $3^{a}$. série), E (4a. série), GU (4a. série), as dificuldades pareciam quase intransponíveis, inviabilizando a operação de corte e de abandono dos restos (por exemplo: ficar apenas com o ME e não pronunciar NINO parece indicar um arraigado apego à palavra como uma unidade completa, indivisa, cujo esfacelamento parece comprometer a subjetividade). Percebemos, nessa dificuldade, certo enrijecimento da relação significantesignificado. Quando a operação de corte, de separação e de "perda" do valor de imagem não funcionam, muito provavelmente a leitura estará comprometida. Esse traquejo que o aluno, no método fônico, em geral aprende de maneira artificial (pelo treino forçado, pela repetição), deixará suas marcas na leitura, que em geral passa a ser lenta, subvocalizada e pouco significativa. Sem levar em conta essa pregnância imaginária, que faz com que o sujeito sinta o peso do significante na hora de brincar com o corte e com a perda de fragmentos significantes, fica difícil promover a emergência de uma subjetividade que aceite o jogo metonímico em que a parte valha pelo todo, em que um sujeito advenha pelo "nonsense" de um significante descolado, pronto para ser esvaziado e repreenchido (condição sine qua non de toda leitura verdadeiramente significativa - demos um bom exemplo dessas operações com o poema de José Paulo Paes (capítulo I).

Interessante notar que esse jogo com o significante, essa capacidade de desprezar a letra como realidade material e suas 
correlações sonoras e de significados constitui um processo complexo que vai desde esse nível de elementos mínimos (fonemas, sílabas, morfemas ou letra, sílaba, afixos e radicais) à leitura de textos complexos e extensos. A dificuldade de se soltar imaginariamente quer da sílaba, da palavra, ou dos sentidos consensualmente construídos, é a dificuldade mais séria da dinâmica subjetiva tanto na língua falada como na escrita.

Poderíamos imaginar que essa pregnância viria da "mãe inadequada", da "família inadequada", enfim, das relações parentais; no entanto, muitos alunos acabam soltando essas amarras em nossos atendimentos e é quando a gente percebe que boa parte delas se origina de um conflito quase insolúvel entre um tipo de uso da língua, que poderíamos chamar de "pregnante" (oralidade de pequeno outro, caseira, regionalizada, altamente contextualizada - construída nesse contexto da oralidade secundária) e a proposta de escrita da escola, que sufoca a corpo-oralidade dessas crianças.

\section{b) Inversão de dissílabos (revestrés)}

Como vimos no capítulo II, a linguagem do revestrés é uma das linguagens criptológicas (secretas) que as crianças do interior e meninos de rua usavam para comunicações secretas antes do advento da TV e dos joguinhos eletrônicos. Em nosso diagnóstico na escola facilitamos a coisa, trabalhando apenas com dissílabos e utilizando palavras do cotidiano das crianças, mais ou menos assim:

- Vou dizer essa palavra - mostrando uma imagem dentro de um grande conjunto - usando a linguagem do revestrés, veja: "togá", o que eu disse?

Com uma lista de imagem na mão, o aluno vai tentando decifrar nossas inversões. Conforme já dissemos, as dificuldades, no início, parecem insolúveis, complexas demais, mas com um pouco de insistência a maioria vai pegando, ainda que em posição passiva (só 
ouvindo e adivinhando). Alguns alunos, para conseguir compreender e admitir a inversão, precisavam se apoiar concretamente em alguma coisa, por exemplo, as duas mãos do pesquisador: la (mão esquerda) bó (mão direita), para o que o aluno pegasse a mão direita, descobrisse que esta marcava o bó, para depois pular para a esquerda redescobrindo o la. Ainda assim, alguns deles após repetir a operação não conseguiam descobrir aí a palavra bola.

A reflexão que desenvolvemos no item anterior serve também para esta atividade, embora ressaltemos que a estratégia que utilizamos, na qual um sentido prévio (a cartela de imagens que está em suas mãos) orientava a procura, acabava facilitando o rompimento dessa posição pregnante do aluno. Com o tempo, boa parte deles já era capaz de inverter, de esconder palavras para o pesquisador procurar.

\section{c) Leitura de rébus}

Como vimos no capítulo I, o recurso do rébus foi o grande achado dos historiadores da escrita, que permitiu decifrações importantes tanto dos hieróglifos como dos cuneiformes. Utilizamos os dois rébus ${ }^{113}$ abaixo como modelo inicial para introduzir essa estratégia:

113 Ao primeiro rébus, em que as unidades sonoras entram integralmente na composição da nova palavra, sem deixar restos, chamamos "rebus perfeito". Ao segundo, em que a leitura (como ocorre com a leitura de palavras - pronunciamos /paredi/, /voceis/, /u homi taí/, mas lemos "parede", "vocês", "o homem está aí") sofre adaptações, chamamos "rébus adaptativo". E ao rébus seguinte (Tiago), escrito a partir do recorte da primeira sílaba, chamamos "rébus acrofônico". 

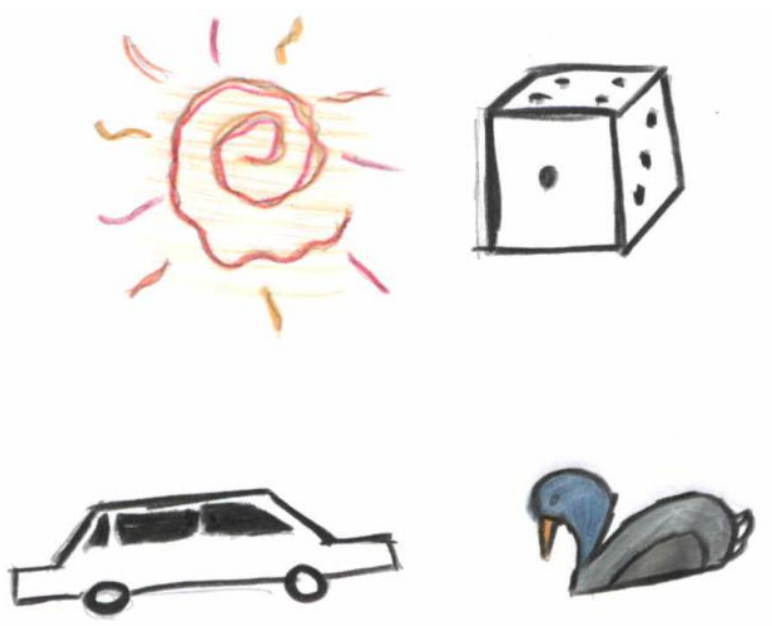

Temos aqui as palavras "soldado" e "carrapato" (com adaptações, pois a leitura de rébus exige adaptações como qualquer outro tipo de leitura).

O recurso do rébus foi amplamente usado em nossas intervenções. Num primeiro momento, procurávamos exercitar bastante a leitura do aluno, desde seu nome a outras palavras e até mesmo frases. Um exemplo notável foi o de Tiago, aluno difícil, que quase não aceitava ajuda e que rejeitava prontamente qualquer coisa escrita. Depois de escrever seu nome em rébus, a imagem de um tijolo, da amora e de uma goiaba (abaixo), o jovem passou a escrever e ler com desenvoltura utilizando estas letras-imagem:

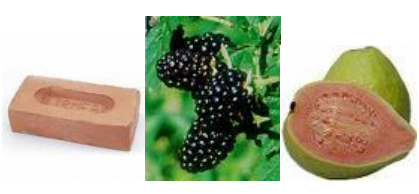

(foto)

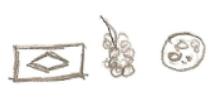

(desenho)

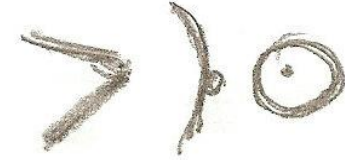

(traço metonímico: ideograma estilizado)

Todos esses modos de escrita foram reconhecidos pelo menino: o mais icônico (foto), o desenho estilizado e o mais ideogramático, no qual se preservava apenas um traço de cada imagem (o ângulo interior do friso do tijolo, um ramo do cacho com apenas uma uva, um círculo com apenas uma sementinha da goiaba).

Em seus conflitos com o pesquisador, como forma de provocálo, Tiago tentou escrever mensagens no campo do proibido, usando 
um repertório de imagens recortadas, duas de seu nome e uma terceira, escreveu:

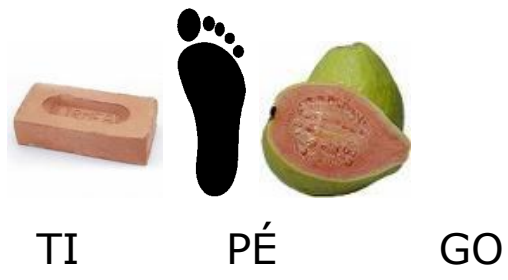

Depois, a partir de ideogramas, começou a desenhar mais agressivamente no campo do proibido:
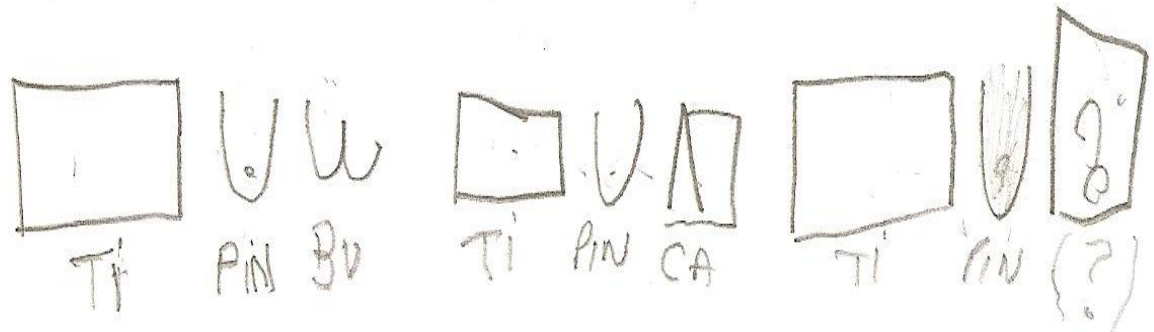

Tonela

(a transliteração sob os desenhos, "ideogramas", foi posta a partir da leitura do aluno). Os desenhos correspondem a um TIjolo, um PINto e uma BUnda, depois, TIjolo, PInto e CAderno e na última palavra: TIjolo, PINto e Janela.

Em outro desenho, ainda muito preso às formas que apresentei, oriundas de seu nome, Tiago apresentou mais uma palavra:
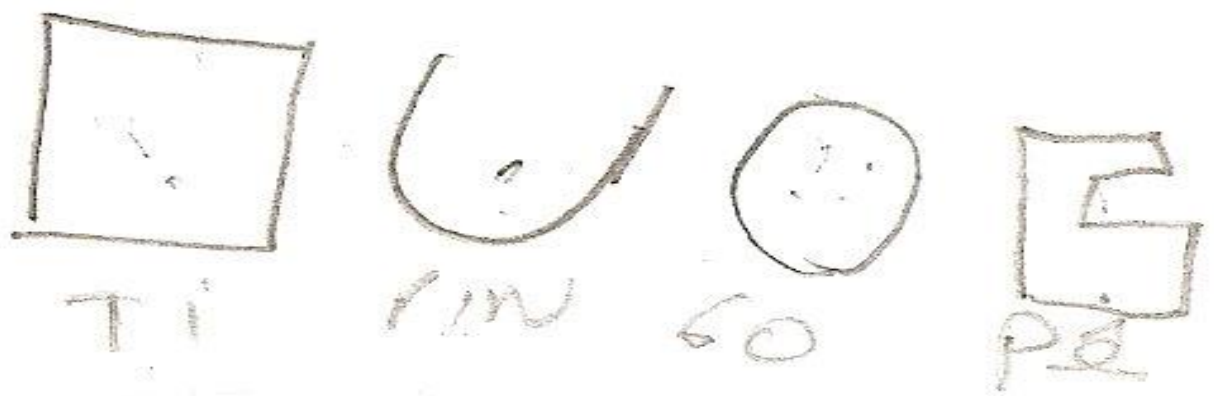

TIjolo

PINto

GOiaba

PÉ 
O episódio mais curioso no atendimento deste menino pode ser visto no diálogo abaixo. O contexto foi o seguinte: estávamos sós em uma sala de aula, sentados em carteiras dispostas frontalmente. Eu acabara de elogiar seu acerto, pois dentre diversas imagens recortadas, Tiago havia selecionado as de seu nome e as remontava sobre a mesa:

"(...)

- Muito bem! Você escreveu, Tiago!

- Eu tenho pinto de homem, é bem grandão!

- (...)

- Meu pinto já é grande. Olha aqui, eu vou mostra pra você!

- Eu num tô aqui pra ver seu pinto! (em tom de repreensão)

- Só dá uma oiada pra você vê (e desce as calças).

(Viro a carteira e fico de costas pra ele. De repente me vem uma ideia)

- Vô desenhá um pinto pra você vê! (ele veste novamente a calça e diz, vindo em minha direção):

- deixa eu vê esse pinto!"

(diante dele, vou desenhando calmamente, até arrematar a figura abaixo):

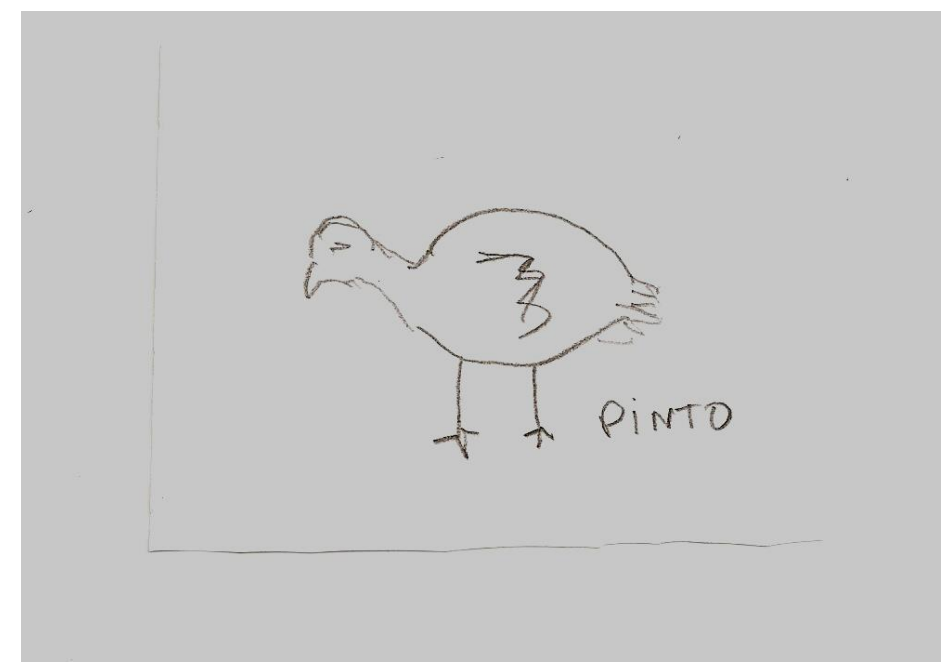

"- Isso é pintinho de galinha!

- Mas é pinto também. Também cresce, fica grande!

- Deixa eu desenhar" (tomou o lápis de minha mão e mandou ver: 


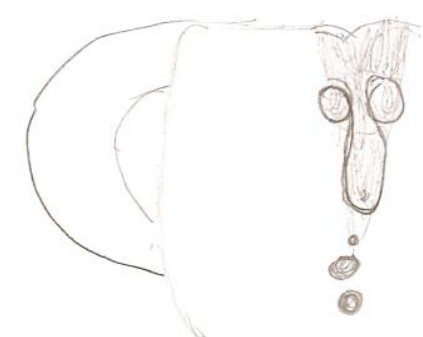

Interessante observar como as letras se implicam, desde o desenho à letra estilizada. Para Pommier (1993), como vimos no capítulo I, o desenho é externalização de um corpo psíquico, em outras palavras, da ordem da pulsão e de suas investidas nas possibilidades representativas. Neste atendimento, o fluxo foi das imagens de objetos que, tratadas como rébus, permitiram uma escrita - do mesmo modelo que a onírica de Freud, uma escrita interior que mobiliza uma subjetividade propensa a expressar-se diretamente através do corpo, exibindo-se. O curioso é que o mínimo de repressão (ou negação), juntamente com uma forma homofônica (pinto de galinha por pinto de menino), levou a situação para uma expressão fora do corpo. 
Situações como esta sempre ocorrem em nossos atendimentos - há outras registradas na tese de Lima (2006) e nas dissertações de Lucas (2010) e Prol Ottero (2010), trabalhos sob nossa orientação.

Apesar de ter-nos fornecido um exemplo interessantíssimo do papel do rébus e até ilustrado o jogo entre a letra psíquica e a letra do alfabeto, o caso de Tiago não terminou em final feliz. Como alguns outros, acabou se distanciando do Ateliê (consta que retornou mais tarde, mas que mantinha uma relação intermitente, difícil de ser assimilada pelas ações do projeto do ACAIA).

O mais importante é que a técnica do rébus tornou-se uma estratégia interessante sobretudo para a criança renitente, que não olha mais para a letra alfabética. Esse retorno à imagem e à redescoberta de sua funcionalidade de letra têm sido um dos nossos pontos de apoio no novo projeto.

\section{A ESCOLA DIANTE DA RENITÊNCIA}

Pelos resultados que analisamos acima, não é difícil perceber que a escola só está preparada para receber o aluno que vem de casa com repertórios orais já bem desenvolvidos e já perpassados pela escrita; mas ainda não o está para receber o aluno que vem para a escola com pequeno repertório oral e, ainda, com uma predisposição a resistir diante das exigências secas da escrita. Essa constatação já é lugar comum desde a década de sessenta (Houston,1997), contudo, atualmente, parece que as crianças oriundas de meios desfavorecidos têm ainda mais motivos para resistir ou, como costumamos dizer, renitir. Além de não se ter um currículo que estabeleça uma transição entre língua oral e língua escrita, a escola assiste impotente a um encavalgamento de suportes. O aluno, mesmo o mais desprovido de recursos, sabe que o livro didático que Ihe chega do Programa Nacional do Livro Didático (PNLD) já não é mais o único objeto de prestígío da elite: sabe, por exemplo, que na 
Internet poderá encontrar diversões e até atividades de estudos mais afeitas ao seu jeito oral e corporal de ser. Em nossos atendimentos aos alunos da Escola Keizo Ishirara, ouvíamos o tempo todo o reclamo dos alunos em relação ao uso da Internet. Um aluno que atendi pessoalmente insistia tanto que queria entrar na Internet, que abrimos o computador e o navegador e dissemos: "tá aí a Internet!". Ele olhou para o navegador, mexeu no teclado e retrucou "isso não é Internet, cadê os joguinhos?" Quando disse a ele que teria que procurar, escrever no espaço de busca do "google", ele se desinteressou: a Internet era só mais atividade que lhe cobrava o domínio da escrita? Um outro aluno, que já havia mexido várias vezes no computador, conseguiu buscar o item "jogos" do Windows e abrir o "Pinball". Jogou aleatoriamente durante algum tempo, sem perceber que os comandos que acionava não correspondiam à sua intenção de reter a bolinha do campo de jogo. Dessas experiências depreendemos que os alunos da rede estadual, sobretudo os mais pobres, entendem que o computador e a Internet servem "para jogar". Talvez essa constatação também sirva para sotopor um limite às dicotomias da moda, "Geração X versus Geração Y" ou "Migrantes nativos versus migrantes digitais". Não é preciso usar de grandes inferências para percebermos que tais oposições, se realmente são verdadeiras, devem se circunscrever à classe média e à alta, nas quais talvez um certo número de crianças e jovens tenham lá talentos que não necessitem de aprendizagem e nem das sabedorias das gerações anteriores.

Nesses momentos da pesquisa, quando utilizávamos equipamentos multimídia para projetar atividades com som, texto, imagens e movimento, os alunos, de fato, entravam em alvoroço, querendo utilizar o computador. Também melhoravam muito a participação quando as atividades dispunham de várias linguagens. Em Belintane (2006c.) procuramos mostrar que as lan-houses 
também atraem as crianças pobres e sobre elas deixam suas sedutoras marcas:

A perseguição ao assassino virtual, a arma poderosa que faz explodir rochas e edifícios, os poderes concedidos por bonificação em razão de ter sido eficiente, os contra-ataques que não perdoam e levam ao "game over", o tempo que exige pagamento de um real a hora, as sinestesias desafiadoras com seus estampidos luminosos e suas granulações rumorejantes e ainda o imaginário simplório do cinema e dos mitos... tudo isso junto parece compor uma janela magnética, aprisionante, bem diferente da aula precária que o Estado põe gratuitamente em cena.

Também constatamos, em diversos cursos de formação de educadores e em nossas análises de guias curriculares oficiais, que a escola brasileira ainda não dispõe de uma concepção ou metodologia que consiga estabelecer um encontro entre esses três pontos: o que a educação pode propor como currículo, como programa; o que a criança traz de seu ambiente; o que esse contexto de encavalgamento de suportes (o gráfico e o eletrônico), de redes e de mídias pode trazer para o ensino.

Se levarmos em conta, como o fizemos no artigo acima citado, que a subjetividade infantil está situada nesse tripé entre a escola com sua escrita; a família com sua oralidade e as mídias com suas seduções, a formação e o trabalho do professor se tornam ainda muito mais complexos do que já o eram nas décadas de sessenta, setenta e oitenta - e o engodo das metodologias eficientes a toda prova cairia por terra.

Em outras palavras, os diagnósticos simplistas propostos pelas redes (capítulo II) não são capazes de pôr em relevo essa bagagem, sobretudo o que ela poderia trazer de mais importante, que é a diversidade textual da cultura oral, com toda a sua corpo-oralidade. 
O projeto efetivou mais uma fase, durante a qual se procurou subsidiar duas séries iniciais do ensino fundamental I, sustentando um programa de ensino baseado nos diagnósticos, ou seja, cada item da tabela 1 abriu um tópico curricular para duas turmas de primeira série, que seriam monitoradas por nós durante o ano letivo de 2009. Com base na ideia de que a heterogeneidade na sala de aula é constitutiva, pois reflete as diferenças sociais e as oriundas das singularidades de cada criança e de suas famílias, ao longo do ano, procurava-se observar também a "dinâmica de renitência" dos alunos que tenderiam a terminar o ano sem o domínio completo do alfabeto e da leitura. A partir da compreensão dessa dinâmica, o programa da escola buscava estratégias que pudessem ser aplicadas de acordo com os níveis e singularidades de cada caso. O objetivo maior era buscar subsídios para afirmar uma proposta mais afeita às complexidades de uma sala de aula de fato heterogênea.

Antes de prosseguir, façamos aqui outra diferença: a escuta de alunos em situação escolar tal como foi exercida nesta pesquisa difere substancialmente da escuta psicanalítica. Se para a psicanálise a escuta, como já apontava Freud $(1988)^{114}$, centra-se na "atenção flutuante", na silenciosa espera de um lapso, de um ato falho ou mesmo nos jogos de condensação e deslocamentos presentes nos relatos dos sonhos, nesta pesquisa também se valorizavam significantes como indícios que emergiam na relação, mas a partir de uma situação de ensino semiestruturada, mediada por atividades literárias, tais como contação de história, declamação, jogos lúdicos e conversas sobre os heróis das narrativas, sobre os modos de brincar e jogar com palavras. Se na clínica a interação do paciente é inteiramente aberta, motivada por situações vividas, imaginadas ou

\footnotetext{
114 Volume XII, "Recomendações aos médicos que exercem a psicanálise" (pp. 125,
} 126). 
mesmo sonhadas e ainda pontuadas pela escansão do analista, nos atendimentos da pesquisa esperava-se o aluno com um arcabouço textual cheio de ambiguidades e de possibilidades de pontuações subjetivas $^{115}$. Entre esses textos surgia sempre um disparador significante, que era um texto lúdico-literário ou um elemento de uma narrativa, como se pode observar nestes dois $\operatorname{casos}^{116}$, um da primeira fase e outro da segunda:

- VG, criança de 11 anos, com quatro anos de escolarização, veio ao atendimento com muitas dificuldades, ainda sem dominar o princípio alfabético e com uma renitência à flor da pele. Engajou-se nos atendimentos a partir da valorização de um significativo indício, obtido quando, ao parafrasear a parlenda "Hoje é domingo", retomou em tom de gracejo o trecho "a gente é fraco/cai no buraco/o buraco é fundo/acabou-se o mundo" e acrescentou: "eu caí no buraco quando era pequeno". Como viu que a pesquisadora valorizou sua fala, continuou: "Minha mãe diz que eu não aprendo a ler porque caí no buraco e o fogão caiu na minha cabeça". A pesquisadora valorizou a associação entre "não ler" e "cair no buraco" e juntos refizeram a parlenda, citando comicamente a situação de VG cair no buraco. Essa delicada escuta de sua situação o levou a gostar mais dos textos usados em aula e das brincadeiras com palavras. Pouco tempo depois, VG foi se engajando muito bem nos atendimentos e escapando, pouco a pouco, da incômoda posição que a fala materna o pôs; no final, afirmava que iria mostrar para sua mãe que

\footnotetext{
115 Pastorello (2009), em seu doutorado (sob nossa orientação), aplicou o mesmo princípio, em sua clínica fonoaudiológica, mas usando a leitura em voz como estratégia para abrir a escrita às crianças.

116 Também o caso já relatado neste capítulo, o de Tiago, mostra uma escuta diferente da psicanalítica, uma escuta que partiu com a atividade do desenho, mas não livre como as utilizadas na psicopedagogia; ou seja, por detrás da atividade já se tem intencionada a lida com a expressão, o rébus e seus efeitos homofônicos.
} 
ele sabia ler, que a história de "cair no buraco" não era verdadeira.

- MT (7 anos, ex-criança de rua). Experimentou um avanço a partir de dois personagens: "O Pequeno Polegar", dos contos de Perrault, e "O Saci", personagem do folclore brasileiro, retomado oralmente e por meio de leitura do livro O Saci de Monteiro Lobato. Segundo o relato de uma das pesquisadoras, o menino questionava a própria natureza da ficção, parecia demonstrar certo estranhamento diante de histórias, quase sempre procurava pontuar a contação introduzindo outras possibilidades de ação em vez de aceitar passivamente a progressão da história como fazem as crianças que aceitam bem a fiç̧ão. Um exemplo: no momento em que Polegar e seus irmãos são abandonados na floresta, o pequeno MT, aflito, interrompia e apontava outra solução: "eles podem correr atrás dos pais e voltar, seguir a trilha deles". Aos poucos, foi assimilando a narrativa, aceitando sua progressão e se identificando com esse minúsculo personagem que, com sua astúcia, vence o imenso Ogro e reconduz seus irmãos à casa. Quanto ao Saci, pequeno ser privado de uma das pernas mas cheio de astúcia e de poderes, deu ao menino possibilidades de bons engajamentos no atendimento. Esses movimentos de sua subjetividade funcionaram como pontos de giro de sua renitência: MT tinha dificuldades de se portar como aluno; como vivia na rua, não tinha sequer noção dos modos de se portar em uma sala de aula ou mesmo do próprio manejo dos materiais escolares. Ao identificar-se com o Polegar e o Saci, suas relações com a contação de história, a leitura em voz alta e com as próprias letras mudaram o suficiente para que grandes avanços acontecessem. Em apenas três meses MT dominava bem o alfabeto, experimentando algumas 
dificuldades apenas com as sílabas complexas (em geral, dígrafos) e sustentando uma posição subjetiva de leitor em formação, ao manifestar grande interesse por livros de história, pela obra de Monteiro Lobato, pelo espaço da biblioteca, pelas brincadeiras e jogos baseados nas narrativas especialmente criadas pelo projeto para as salas de aula117.

A partir desses e de outros casos vividos no projeto, começou a ser possível delinear um modelo de atendimento que, apesar de basear-se na escuta psicanalítica, também se estrutura no manejo linguístico-literário de textos da cultura oral infantil. Por exemplo, no caso I, uma parlenda e a aceitação de um nonsense permitiram ao aluno uma aproximação maior com as propostas de ensino; no caso II, é uma narrativa com seu universo ficcional mítico que favorece essa abertura. A partir dessa ambiência ficcional repleta de ambiguidades, torna-se mais fácil a emergência de uma subjetividade predisposta a um confronto entre uma corporalidade excessiva (correr e brincar sem muitas regras) e as posturas de contenção que a escrita põe em jogo (sentar-se, fixar a atenção). Nesse ponto é que a situação começa a se aproximar de uma dinâmica transferencial a partir da qual os valores podem ser reequilibrados. Do mesmo modo que na clínica psicanalítica o paciente invariavelmente apresenta uma teoria para o seu sintoma e acaba incluindo o analista como parte dessa teoria e do próprio sintoma (Nasio, 1993), no atendimento o pesquisador se depara com explicações próximas às duas relatadas, em que o pesquisador também é convidado a compartilhar dos motivos pelos quais a criança diz não conseguir se dar bem com a escrita.

$117 \mathrm{O}$ atendimento desta criança foi realizado pela mestranda Katia Arilha Fiorentino Nanci, que apresentará o caso completo, acompanhado de outros oriundos de nossa nova pesquisa, em sua dissertação de mestrado. 
O mesmo ocorre com a concepção que o aluno apresenta sobre seu modo de ler ou de enfrentar as letras e textos. Por exemplo, ocorriam muitas verbalizações como estas: "é preciso ler bem devagar pra não errar"; "eu só sei escrever, não sei ler"; "isso não é aula porque não tem nada pra copiar"; "vou escrever do meu jeito"; "não vou ler nada". Da conjunção desses dois tipos de explicação é possível detectar alguns posicionamentos subjetivos diante da escrita: (1) de conformismo com justificativa familiar; (2) de excessiva precaução diante da possibilidade de erro; (3) de displicência; (4) de compensação (diz saber outra coisa, por exemplo escrever, copiar); (5) de renitência; (6) de infantilização. Essa lista pode ser aberta, e o número dessas posições não precisa ser fixado. O importante é incluir, na escuta, essa prontidão, a ideia de que essa explicação (a teoria sobre o sintoma/fracasso) acabará aparecendo e precisará ser ressignificada.

É interessante reforçar que o conceito de sujeito que norteia esta pesquisa não é o mesmo que o sustentado pelos construtivistas ou sociointeracionistas - o sujeito ativo que muda de fases, que constrói a escrita a partir de suas tentativas e erros -, mas sim um sujeito excêntrico, que se posiciona em relação ao discurso do Outro e que emerge na linguagem de forma evanescente, entre palavras, entre frases, entre textos. Por exemplo, MT, quando iniciou o atendimento, apresentava uma posição de renitência, mas ao encantar-se com as histórias do Pequeno Polegar e do Saci e com sua atendente (que era a fonte dessas histórias), ganhou certa fluidez e aceitou se reposicionar diante das letras e das atividades de leitura e escrita. No entanto, a equipe sabia que sua posição oscilaria, ou seja, partia da ideia de que essa predisposição que se parecia com a de um sujeito ativo poderia se eclipsar e exigir novas estratégias da pessoa que o atendia. Outro fato interessante que parece corroborar a hipótese dessa evanescência subjetiva é o fato de MT e de outros alunos atendidos não transferirem diretamente para a sala de aula os 
conhecimentos adquiridos nos atendimentos; para que isso acontecesse, ainda que parcialmente, foram necessárias estratégias específicas como, por exemplo, transferir para a sala de aula um conteúdo que o aluno dominou no atendimento; ou ainda o atendente ministrar algumas aulas junto com o professor da sala e reconhecer explicitamente a mudança de posição do aluno.

O modelo de escuta que aqui se buscou, e que ainda se busca, se baseia na linguagem e tem a oralidade e a literatura como ferramentas. Diferentemente de outras escutas, seu objetivo é bem explícito: mudar o posicionamento subjetivo do aluno em relação à escrita e à oralidade. Escutar, portanto, é uma atividade cuja ética e técnica estão sendo redefinidas especificamente para este campo, pois ficou muito claro na pesquisa que, desde as séries iniciais, é preciso valorizar as sutis verbalizações ou atitudes dos alunos, para reposicioná-los diante de uma oralidade mais linguageira, mais propensa à função poética, ou seja, rica o suficiente para dar consistência às escansões do alfabeto e à lógica textual da leitura e da escrita.

Nas conclusões desta segunda fase, uma constatação referente às condições de entrada da criança neste ciclo se destacou: não há, pelo menos nesta escola, uma preocupação explícita em conhecer melhor essa criança e suas condições de oralidade e letramento (o que ela traz de seu meio e da educação infantil). A equipe procurou conhecer as pastas dos alunos oriundos das escolas de educação infantil, mas como não há ainda uma prática que sistematize essa transição, os materiais das crianças só foram entregues pelos pais um mês após o início das aulas - o ideal teria sido iniciar o ano a partir da avaliação desse material ${ }^{118}$.

118 A nova pesquisa, em andamento, já introduziu esta preocupação: retomar as pastas que as crianças trazem do ensino infantil. Em nossas primeiras análises já constamos uma "terra de ninguém", ou seja, os programas escolares parecem depender mais da boa vontade deste ou daquele professor, dentro de uma mesma 
Após a análise das pastas recebidas, foi possível detectar que boa parte das atividades ministradas às crianças visava diretamente 0 domínio dos números e letras. Em apenas uma das escolas infantis se detectou uma preocupação mais sistemática com os textos de origem oral, mas mesmo assim, pelo que pudemos analisar, os textos eram instrumentalizados por objetivos ligados ao domínio da escrita. O envolvimento da equipe com os alunos ao longo do ano confirmou essa suspeita inicial: as crianças possuíam um repertório pequeno e pouco diversificado de gêneros orais da infância, ou seja, na educação infantil não tiveram oportunidades de lidar suficientemente com textos de origem oral de modo que estes de fato constituíssem um lastro de memória textual.

Baseada nessas constatações, a equipe procurou, juntamente com os professores da escola, ministrar um programa que pudesse articular uma rede de textos orais; ou seja, a preocupação era garantir que um certo número de textos de alguns gêneros, por nós considerados estratégicos, fosse se estabilizando na memória, como matrizes narrativas ou fontes de habilidades linguageiras com as quais e entre as quais pudesse emergir uma subjetividade mais condizente com as exigências da leitura e da escrita. Conforme já foi dito, se na memória do aluno há um enredamento de textos que se associam, quer por temas comuns, quer por seus elementos formais, o efeito dessa rede deverá se dar também no campo da escrita. Se o aluno sabe ouvir, contar e relacionar histórias (intertextualidade temática), se tem textos lúdico-poéticos na memória e aprendeu a identificar os elementos estéticos de cada gênero oral (paralelismos, aliterações, assonâncias, rimas e outras iterações), muito provavelmente sua leitura e seu manejo da escrita se tornarão mais dinâmicos e significativos.

escola. É o caso, por exemplo, da creche Oeste da USP, onde há uma programação que promete trabalhar em todas as turmas com textos oriundos da cultura oral, mitos e outros, mas a execução do programa difere muito de uma turma para outra, em razão dos manejos didáticos dos professores. 
A equipe procurou mobilizar os professores das duas turmas, para que entendessem bem os princípios que norteavam a perspectiva de trabalho, e para que inserissem em seus programas itens propostos pelo projeto. No entanto, essas inserções não puderam ser feitas sem levar em consideração o programa curricular do Projeto "Ler e Escrever". A partir das hipóteses do Projeto, algumas estratégias nortearam essas inserções:

1. Diagnóstico oral coletivo - Iniciou-se o processo por um diagnóstico coletivo, ou seja, por meio de conversas com a sala procurava-se mapear o universo temático e formal dos textos orais que as crianças traziam na memória, e suas predisposições para a escuta e participação em atividades performáticas.

2. Atividades performáticas - Nas atividades performáticas coletivas, um pesquisador observava a reação dos alunos que apresentavam indícios de pouco repertório, ou mesmo pouca prática em atividades orais coletivas. Em cada sala foi possível notar, desde o início, que oito ou nove alunos apresentavam participações não favoráveis à atividade: evasão completa, participação exagerada e indisciplina. Esses alunos eram entrevistados e atendidos isoladamente e, sempre que possível, procurava-se recuperar a atividade ou conversar sobre ela. Nas aulas subsequentes dedicavase especial atenção ao engajamento desses alunos.

3. Percurso para atividades orais - As atividades seguiam o seguinte percurso: (1) performance, (2) conversa sobre a atividade, (3) levantamento de brincadeira ou história semelhante na memória dos alunos, (4) pesquisa em casa e/ou em livros com o objetivo de buscar semelhanças, (5) organização de coletâneas. Alguns exemplos poderão ilustrar o processo:

- Adivinhas - Como os alunos haviam recebido o material escolar do governo e, segundo os professores da sala, esse momento era de grande euforia, a equipe resolveu apresentar 
algumas adivinhas cujas respostas eram exatamente os materiais que eles tinham em mãos (exemplo: "nasce grande e morre pequeno" - resposta: o lápis). O trabalho foi um sucesso e finalizou com um livro de adivinhas. No retorno do segundo semestre o coordenador do projeto constatou que os alunos se recordavam facilmente do nome de todos os materiais, de suas adivinhas e de outras já abordadas no primeiro.

- Contos europeus e brasileiros: Como as crianças traziam na memória apenas alguns contos europeus, os mais abordados pela mídia, a equipe tinha como missão ampliar rapidamente esse repertório e, de preferência, enredar uma intertextualidade introduzindo inclusive diversos contos brasileiros. Foram narrados e entrelaçados, logo no início, os seguintes contos: João e o pé de feijão, João e Maria e $O$ Pequeno Polegar, além de se abrir também um repertório de contos brasileiros: A árvore de Tamorumu, O Macaco Simão, O macaco e o pé de milho, $A$ história da coca, $A$ árvore da montanha, $A$ velha a fiar e outras. Após as performances e as conversas os alunos conheciam os contos nos livros ou, quando fosse o caso, em filmes. Somente após o domínio dessas matrizes é que se começou a trabalhar com trechos, palavras, frases e imagens como motivadores dinâmicos para o uso da escrita.

4. Memória entre textos, imagens e suportes: No diagnóstico da fase I, como vimos, o rébus apareceu com um grande problema para os alunos que não dominavam a escrita mesmo após três ou quatro anos de escolarização. No acompanhamento dos alunos, ainda na fase I, revelou-se um recurso extraordinário essa redescoberta da "letra". No programa para as duas séries o rébus foi assumido como uma estratégia especial, pois, além de ser tomado como uma dobradiça entre a imagem e a escrita, também funcionou 
como um forte elemento de diagnóstico qualitativo, bem mais interessante que as fases ou níveis de Ferreiro y Teberosky (1989), uma vez que a passagem da imagem para a sílaba exige "cortes" e "perdas" cujos sentidos vão além do domínio consciente da escrita. Mostramos aos professores exemplos das implicações que a leitura dos rébus propõe:

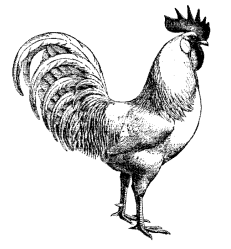

GAlo

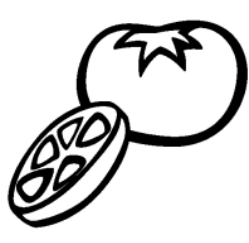

TOmate
$=$

GATO

Como as atividades do projeto sempre procuravam um enredamento de níveis (sílaba, palavra, texto), o gato redescoberto a partir de Galo e TOmate, assim como outras palavras, permitiam redescobrir uma parlenda escondida (as palavras gato, mato, fogo, água, boi, trigo, galinha, ovo, padre e missa formavam a parlenda Cadê o toicinho daqui?). A brincadeira era denominada "descubra a parlenda".

O rébus também era a base de vários jogos elaborados pela equipe no suporte eletrônico, nos quais o aluno redescobria, além das parlendas, outras brincadeiras orais e as narrativas que já traziam na memória. Além dessa leitura do rébus, também se praticava a leitura de ilustrações dos livros; por exemplo, liam-se episódios do Pequeno Polegar nas gravuras de Gustave Doré, as quais serviam como apoio mnemônico, sobretudo para as crianças que ainda não tinham prática na reconstrução de narrativas.

O recurso do rébus é praticamente combatido por construtivistas e sociointeracionistas, por ser compreendido como pedagogia das partes menores da palavra e figurar como uma espécie de silabação. Contudo, em nossa pesquisa, ele se mostrou 
eficaz e indispensável, sobretudo para os alunos que apresentam dificuldades para compreender a sílaba como um algoritmo.

O cinema também foi utilizado: as duas animações de Michel Ocelot, Kiriku e a feiticeira e Kiriku e os animais selvagens, foram projetadas mais de uma vez. Muitas cenas foram isoladas para que as narrativas fossem reconstituídas de uma forma bastante completa. As narrativas cinematográficas também eram reutilizadas em joguinhos de computador produzidos especialmente para o projeto ${ }^{119}$.

5. A nomeação - Outro ponto igualmente importante propunha a expansão do tema "nomeação", cujo objetivo era não apenas ampliar o vocabulário, mas também pôr a criança diante de dois fenômenos: (1) a relação entre termos mais genéricos (hiperonímia: árvores, animais, passarinhos) e nomes populares mais específicos (ipê, raposa, tié-sangue), chamando a atenção para o modo de nomeação ("Por que este passarinho se chama "quero-quero?", "E este aqui, por que se chama "coruja buraqueira?"), enfim, para os efeitos de criação de sentidos (onomatopeias, efeitos metafóricos e metonímicos); (2) a relação significante, evidenciando nomes estranhos, com efeitos sonoros curiosos, por exemplo, "murucututu" (um tipo de coruja), "jaratataca" (um tipo de gambá), "xexéu" (um pássaro). Tais palavras possibilitavam que algumas crianças percebessem as repetições de vogais e consoantes, o que permitia acrescentar ao processo a dimensão do poético, de um efeito significante que vai além da relação direta entre significante e significado: as consoantes bilabial $[\mathrm{m}]$ e linguodental $[\mathrm{t}]$ e o tepe alveolar do $[r]$, associados à repetição do $[\mathrm{u}]$, que é também vogal fechada, introduzem novos sentidos para essa coruja, cujo canto e mistério parecem ressonar em seu próprio nome; o mesmo acontece com a "jaratataca", que se abre em seus estalidos e saltos. Constatamos que os onomatopaicos e a remotivação sígnica podem

\footnotetext{
119 Nos anexos, dispusemos um CD com essas atividades, que podem ser executadas em qualquer computador.
} 
ter um papel fundamental na alfabetização. Na pesquisa atual já se vislumbra, nas duas séries iniciais, uma dificuldade com a nomeação até de imagens banais do cotidiano, por exemplo, boa parte das verduras, legumes e frutas são nomeados com hiperônimos, como disse uma das professores: "tudo é fruta, tudo é verdura, o nome de cada uma quase não vem".

Como se pode observar, a pesquisa insistiu na formação de uma base textual na memória, tomando sempre como ponto de partida a oralidade performática, o corpo como suporte, mas sempre explorando paralelamente outras linguagens e suportes (escrita, gravuras, cartazes, livros, computador e cinema). Ficou claro para a equipe que, desse enredamento, são obtidos efeitos muito positivos na dinâmica das salas: as constantes redescobertas dos textos, das palavras, das imagens, resultaram em uma ambiência educacional rica, diversificada e interativa.

6. Alternâncias: contar, ler; ler e contar - Outra estratégia importante utilizada pelo grupo foi a alternância entre as modalidades de narrativa. A contação de história entrava sempre em primeiro plano, pois era a principal responsável pelo lastro de memória narrativa. A leitura vinha em seguida e, por fim, o comentário, as trocas de opiniões. Exemplo: o saci, como personagem do folclore, foi apresentado por meio de conversa e de contação de história, depois por meio do livro $O$ saci, de Lobato, cuja narrativa era parafraseada e, ao mesmo tempo, lida em voz alta. O ponto mais alto dessa atividade era atingido quando o professor, diante de um momento mais catártico, interrompia a leitura e deixava o trechinho final por conta dos alunos, que se esforçavam e se lançavam à leitura em duplas ou em pequenos grupos. Cabe aqui uma importante observação quanto à formação de professores: levando-se em conta esta pesquisa e os cursos de formação de professores que ministramos nas redes públicas, e também os depoimentos de 
professores de nossa pesquisa em rede, pode-se concluir que boa parte dos professores não se sente responsabilizados quando dizem não saber contar história ou mesmo realizar outras atividades performáticas com as crianças, como, por exemplo, alternar "leitura em voz alta" com "contação de história"; ou, ainda, estimular atividades que agreguem corpo em movimento, ritmo e voz. Os argumentos, em geral, são os seguintes: "não consigo memorizar histórias e textos"; "os alunos são muito indisciplinados e tudo se transforma em bagunça"; "o programa é muito longo, não posso perder tempo com brincadeiras", e outros. Essas habilidades deveriam ser compreendidas como indispensáveis para o exercício da profissão e ser exigidas em concursos públicos e no próprio trabalho.

7. Acompanhamentos paralelos - Nossos diagnósticos deixaram claro, em seus resultados, que as salas de aula já são heterogêneas desde o início, ou seja, haverá descompassos nos níveis de aprendizagem desde o bimestre inicial. Se se quiser, portanto, assumir de fato uma política de alfabetização e leitura, será necessário manter um trabalho de equipe que extrapole o modelo vigente (um professor para cada sala com trinta ou mais alunos). Como, entre os construtivistas brasileiros, disseminou-se a ideia de que a criança tem até dois anos para se alfabetizar, todas as sobras da antiga $1^{\text {a }}$. série iam para a segunda sem 0 menor constrangimento. O que não se percebe é que, desde o atual primeiro ano do Fundamental (seis anos), o aluno que não assimila o ritmo das atividades de domínio do código já se põe como subjetividade renitente, como aquele que não consegue aprender a ler e que, por esse mesmo motivo, se isola também das brincadeiras orais e de outras atividades coletivas. Portanto, esse primeiro ano do fundamental de nove anos tem que ter um programa preciso, já levando em conta o fenômeno da heterogeneidade e a possibilidade da renitência. 
O projeto realizou a experiência de diagnosticar e acompanhar esses alunos em suas singularidades, procurando detectar seus movimentos de aproximação e de afastamento em relação ao universo da leitura e da escrita. A equipe acompanhou os alunos que, desde o início, destoavam da turma. A síntese desse resultado segue na Tabela 4:

Tabela 4 - Comparação entre situação inicial e final

\begin{tabular}{|c|c|c|}
\hline Aluno & Situação em 04/ 2009 & Situação em 12/2009 \\
\hline Dan & $\begin{array}{l}\text { Brincava excessivamente, sem muita } \\
\text { atenção às atividades coletivas. Pouca } \\
\text { concentração tanto na oralidade como } \\
\text { na escrita. Demonstrava algumas } \\
\text { habilidades orais e na escrita } \\
\text { (memorizava com facilidade e } \\
\text { rapidamente assimilou o mecanismo da } \\
\text { sílaba), no entanto seu difícil } \\
\text { engajamento nas atividades coletivas o } \\
\text { deixava fora das atividades e, com isso, } \\
\text { ele não retinha nem expandia o pouco } \\
\text { que aprendia. }\end{array}$ & $\begin{array}{l}\text { Seu atendimento, inicialmente, foi } \\
\text { prejudicado pela baixa assiduidade. } \\
\text { Graças à exploração de textos orais e } \\
\text { imagens mais próximos de seus } \\
\text { interesses e fantasias (futebol, } \\
\text { aventuras), conseguiu avançar. Chegou } \\
\text { ao final do ano lendo com alguma } \\
\text { lentidão, em razão de algumas } \\
\text { dificuldades com as sílabas complexas. As } \\
\text { atividades com rébus tiveram um papel } \\
\text { importante em seu desempenho. }\end{array}$ \\
\hline Tha & $\begin{array}{l}\text { Embora com boa memória textual e com } \\
\text { relativa destreza no domínio de } \\
\text { atividades linguageiras, apresentava } \\
\text { certa apatia e pouco envolvimento com } \\
\text { a escrita - uma posição subjetiva } \\
\text { sustentada pela mãe, que afirmava ser } \\
\text { seu filho "preguiçoso para ler". Sua } \\
\text { baixa assiduidade também prejudicava } \\
\text { seu envolvimento com as atividades de } \\
\text { escrita; talvez até estas suscitassem } \\
\text { suas constantes ausências. }\end{array}$ & $\begin{array}{l}\text { Apesar de não ter frequentando os } \\
\text { encontros com assiduidade, experimentou } \\
\text { avanços no domínio do alfabeto e do } \\
\text { rébus, mas não o suficiente para ler com } \\
\text { autonomia um texto simples. Sua } \\
\text { compreensão ainda era prejudicada pela } \\
\text { lentidão na composição das sílabas. }\end{array}$ \\
\hline Joa & $\begin{array}{l}\text { Manifestava muita renitência em relação } \\
\text { às letras e verbalizava o desejo de } \\
\text { retornar à EMEF, onde "só brincava". } \\
\text { Sua baixa assiduidade também o } \\
\text { prejudicava. Nos diagnósticos orais } \\
\text { revelava destreza e facilidade, mas } \\
\text { resistia em transpor tais facilidades para } \\
\text { as atividades com textos escritos. }\end{array}$ & $\begin{array}{l}\text { O problema da baixa assiduidade foi } \\
\text { resolvido a partir do segundo semestre, } \\
\text { após contatos com a família. Em pouco } \\
\text { tempo o aluno, além de ter melhorado } \\
\text { sua escuta de narrativas, demonstrava } \\
\text { domínio do rébus, do mecanismo das } \\
\text { sílabas, mas encerrou o ano ainda com } \\
\text { dificuldades na compreensão de palavras } \\
\text { durante a leitura. }\end{array}$ \\
\hline Day & $\begin{array}{l}\text { Apresentava dificuldades até mesmo } \\
\text { para reconhecer letras iniciais. Tinha a } \\
\text { sequência do alfabeto na memória, mas } \\
\text { muito mais como ritmo do que como } \\
\text { unidades funcionais. Isoladamente, } \\
\text { confundia as letras tanto em suas } \\
\text { formas visuais como em suas funções. } \\
\mathrm{Na} \text { pronúncia de rébus, não conseguia } \\
\text { destacar a primeira sílaba, pronunciando } \\
\text { sempre a palavra inteira. } \\
\text { Nas atividades orais, quando } \\
\text { estimuladas }\end{array}$ & $\begin{array}{l}\text { A partir de letras de música, jogo da } \\
\text { memória com letras, atividades com } \\
\text { rébus e com textos oriundos de seu } \\
\text { repertório, o aluno mudou parcialmente } \\
\text { sua posição, passando a aceitar melhor o } \\
\text { atendimento e os desafios do alfabeto, } \\
\text { embora, em seus diagnósticos finais, } \\
\text { ainda não conseguisse reconhecer } \\
\text { palavras após ter reconhecido letras e } \\
\text { montado, com dificuldades, algumas } \\
\text { sílabas. Esse aluno só começou a ser } \\
\text { atendido no segundo semestre, o que }\end{array}$ \\
\hline
\end{tabular}




\begin{tabular}{|c|c|c|}
\hline & $\begin{array}{l}\text { demonstrava certa predisposição ao } \\
\text { envolvimento. }\end{array}$ & $\begin{array}{l}\text { dificultou ainda mais a sua recuperação a } \\
\text { tempo. }\end{array}$ \\
\hline Jen & $\begin{array}{l}\text { Foi o caso mais complexo das duas } \\
\text { séries. Sua posição subjetiva era sempre } \\
\text { de fuga, de isolamento. Sua entrada na } \\
\text { escola se deu junto com a sua } \\
\text { internação em um asilo, a partir de } \\
\text { ordem judicial. Como ex-moradora de } \\
\text { rua, Jen não tinha sequer ideia das } \\
\text { obrigações ou do modo como um aluno } \\
\text { se posiciona diante dos outros da sala. } \\
\text { Não reconhecia nem mesmo as iniciais } \\
\text { de seu nome, recusava-se a participar } \\
\text { das atividades orais e não manifestava } \\
\text { interesse nem mesmo pelos joguinhos } \\
\text { no computador. Estava sempre } \\
\text { andando, correndo e se pondo fora do } \\
\text { alcance de quaisquer intervenções. }\end{array}$ & $\begin{array}{l}\text { O atendimento se centrou mais na } \\
\text { interação, na escuta de suas } \\
\text { singularidades. Jen aprendeu a brincar, a } \\
\text { ouvir histórias e comentá-las, chegando } \\
\text { mesmo a memorizar duas parlendas. } \\
\text { No campo da leitura, passou a aceitar as } \\
\text { atividades com letras e com livros em } \\
\text { geral. No final, já dominava o alfabeto e, } \\
\text { com ajuda, conseguiu ler alguns rébus. }\end{array}$ \\
\hline Bre & $\begin{array}{l}\text { Demonstrava pouco interesse por todos } \\
\text { os tipos de atividade. Seu professor a } \\
\text { considerava "apática", embora, por meio } \\
\text { do choro, demonstrasse preocupação } \\
\text { com suas dificuldades em sala. Tinha } \\
\text { dificuldades para prestar atenção às } \\
\text { histórias e não se envolvia em } \\
\text { atividades lúdicas, ou o fazia com muitas } \\
\text { reservas. Na escrita, suas dificuldades } \\
\text { eram globais, não reconhecia sequer as } \\
\text { letras. }\end{array}$ & $\begin{array}{l}\text { Após ter estabelecido uma boa relação } \\
\text { com sua atendente, avançou em todos os } \\
\text { campos, desde o interesse pelas } \\
\text { narrativas e pelos jogos orais ao domínio } \\
\text { do alfabeto. Encerrou o ano ainda com } \\
\text { dificuldades, mas já dominando letras e } \\
\text { famílias silábicas. Suas constantes faltas } \\
\text { prejudicaram muito a sua progressão. }\end{array}$ \\
\hline Mat & $\begin{array}{l}\text { Ex-morador de rua, vinha do abrigo para } \\
\text { a escola praticamente escoltado. Passou } \\
\text { por uma adaptação difícil, mas } \\
\text { surpreendia e até mesmo se destacava } \\
\text { nas atividades performáticas, embora } \\
\text { não raro sua participação fosse } \\
\text { exagerada e desandasse em conflitos. } \\
\text { Não dominava sequer as letras de seu } \\
\text { nome e ainda não sabia escutar uma } \\
\text { história; procurava sempre demonstrar } \\
\text { que eram todas falsas, "tudo mentira", } \\
\text { ou seja, o aluno parecia não suportar a } \\
\text { ficção ou o envolvimento com a } \\
\text { narradora. }\end{array}$ & $\begin{array}{l}\text { Seus avanços foram notáveis em todos os } \\
\text { itens avaliáveis: oralidade, leitura e } \\
\text { escrita, atividades performáticas. No final } \\
\text { do ano ainda mantinha pequenas } \\
\text { dificuldades com algumas sílabas } \\
\text { complexas, mas já demonstrava nítidas } \\
\text { capacidades de superação. } \\
\text { As narrativas ("Pequeno Polegar", "O } \\
\text { saci") tiveram um papel fundamental em } \\
\text { seu progressivo sucesso. }\end{array}$ \\
\hline Cau & $\begin{array}{l}\text { Apresentava dificuldades em todos os } \\
\text { gêneros de textos orais, não } \\
\text { conseguindo memorizar nem mesmo } \\
\text { pequenos trechos. Reconhecia apenas } \\
\text { algumas letras do alfabeto e } \\
\text { demonstrava pouca familiaridade com o } \\
\text { manejo de livros, mesmo ao ler } \\
\text { narrativas com imagens. }\end{array}$ & $\begin{array}{l}\text { Muito prejudicado pela baixa frequência, } \\
\text { com número de faltas acima de } 50 \% \text {, } \\
\text { mesmo assim o aluno demonstrava } \\
\text { avanços importantes, envolvia-se com } \\
\text { narrativas, esforçava-se para narrar } \\
\text { episódios e dominar jogos orais. Seu } \\
\text { domínio da leitura avançava e regredia } \\
\text { em função de suas faltas. }\end{array}$ \\
\hline Dar & $\begin{array}{l}\text { Aluna com saúde fragilizada, inclusive } \\
\text { com problemas oftalmológicos. } \\
\text { Apresentava dificuldades tanto na } \\
\text { oralidade (memorização) como no } \\
\text { reconhecimento das letras e de rébus. }\end{array}$ & $\begin{array}{l}\text { Seu acompanhamento foi precário em } \\
\text { razão das constantes ausências, mas } \\
\text { mesmo assim avançou no domínio das } \\
\text { sílabas, na leitura de imagens e no } \\
\text { domínio da escrita do seu nome } \\
\text { completo. }\end{array}$ \\
\hline \multirow[t]{2}{*}{ Cla } & $\begin{array}{l}\text { Já dominava os nomes das letras, mas } \\
\text { não sabia suas funções. Envolvia-se bem } \\
\text { com atividades orais. }\end{array}$ & $\begin{array}{l}\text { Experimentou um rápido avanço; em } \\
\text { pouco tempo já estava com o nível } \\
\text { equiparado à série, lia com fluência e com } \\
\text { dificuldades típicas da idade. }\end{array}$ \\
\hline & $\begin{array}{l}\text { Sua participação nas atividades parecia } \\
\text { ser afetada pela sua timidez. Possuía }\end{array}$ & $\begin{array}{l}\text { Mudou sua posição subjetiva em relação } \\
\text { à leitura; terminou o ano lendo e }\end{array}$ \\
\hline
\end{tabular}




\begin{tabular}{|l|l|l|}
\hline Mel & $\begin{array}{l}\text { uma posição subjetiva bastante } \\
\text { negativa, afirmando com frequência que } \\
\text { não sabia ler. De fato, seu domínio do } \\
\text { alfabeto ainda era precário, a ponto de } \\
\text { não conseguir identificar as letras de seu } \\
\text { sobrenome. }\end{array}$ & $\begin{array}{l}\text { comprendendo textos simples, embora } \\
\text { com lentidã }\end{array}$ \\
\hline
\end{tabular}

Legenda: Aluno ( três letras iniciais do nome);

Esses acompanhamentos foram realizados por pós-graduandos, alunos de iniciação científica e estagiários, com supervisão semanal do coordenador do projeto. A intenção era buscar um modelo de trabalho em equipe. Esses atendimentos permitiram algumas conclusões:

1a Assiduidade é fundamental. Boa parte dos alunos que entram em defasagem de nível, apesar da oferta de acompanhamento paralelo, o faz em razão de sua baixa frequência. Durante os atendimentos era comum um aluno experimentar avanços tanto na expansão de sua memória oral como no domínio do alfabeto, mas sofrer igual retrocesso após uma ausência prolongada. Uma das pesquisadoras do grupo ${ }^{120}$, mestranda sob nossa orientação, direcionou sua pesquisa às famílias, tentando compreender o porquê desse aparente desleixo em relação à escola. Apesar de o trabalho ainda não estar concluído, a pesquisadora encontrou um conjunto complexo de motivos, que vão desde dificuldades familiares (por exemplo, conflitos parentais) a outras ligadas ao trabalho da família (saem cedo de casa, a criança fica sozinha e decide por si) ou mesmo a moradia e transporte.

\section{2a Um trabalho em equipe ("a dobradiça"). A} responsabilidade pelas séries iniciais deve ser atribuída a uma equipe composta por educadores da educação infantil e das duas séries iniciais - poder-se-ia usar a imagem de uma dobradiça como

${ }^{120}$ Giorgion (2010) investiga as dificuldades que as famílias pobres têm para manter seus filhos na escola, mesmo com todas as ajudas e subsídios dos governos (transporte escolar, merenda, uniforme, material escolar, bolsa família e outros). 
metáfora para a articulação entre a educação infantil e início do ensino fundamental I: o currículo tem que ser articulado, a continuidade do programa tem que ser garantida, não se pode compreender a $1^{\mathrm{a}}$. série do fundamental como marco zero. Cada turma de $1^{a}$. série poderia ficar sob a responsabilidade de uma dupla de professores, sendo um deles mais especializado em conhecimentos linguísticos e mais predisposto a uma formação contínua em torno de estudos que favoreçam a compreensão das singularidades, ou seja, teria disponibilidade para diagnosticar e atender alunos em agrupamentos ou em sessões individuais, de acordo com as necessidades. Esse manejo se daria a partir de diagnósticos tanto da oralidade do aluno como do seu envolvimento com a escrita e com a própria relação educativa (posicionamento subjetivo). Como se observou nas duas fases da pesquisa, a renitência do aluno diante da escrita é progressiva, torna-se cada vez mais complexa ao longo dos anos; portanto, não é conveniente esperar até o terceiro ano de escolarização, como faz o programa PIC da rede municipal de educação (São Paulo, 2006), para inserir classes de recuperação. O que aqui se preconiza é diferente do que a Secretaria Municipal de São Paulo almeja com o TOF (Toda Força ao Primeiro Ano), cujo modelo, assumido também pela Rede Estadual de São Paulo, prevê "junto a cada professor do 10. ano um auxiliar aluno pesquisador - estudante de Pedagogia e Letras" (São Paulo, 2006 , p. 5) e um programa de formação que se esmera em se definir como construtivista, cujo foco é a escrita em detrimento da oralidade (Belintane, 2008), da leitura (Bajard, 1992) e de outras dimensões da linguagem (Borges, 2006; Bosco, 2002). Como se observou na pesquisa, a excessiva submissão ao construtivismo no cotidiano escolar redunda em dois problemas graves: (1) numa técnica única de diagnóstico, centrada na escrita, por meio da qual se classificam os alunos; (2) numa forte ideologização contra o uso de famílias silábicas e de outras técnicas que utilizam os elementos 
menores da língua e da escrita ${ }^{121}$. O que a pesquisa constata é que o isolamento do professor com sua classe, associado a esse sistema classificatório de diagnóstico centrado na escrita, deixa de lado as questões mais candentes de uma sala de aula concreta, que, em geral, requerem uma escuta mais detalhada de sua heterogeneidade e estratégias mais contextualizadas e diversificadas.

$3^{\text {a }}$ Deslocar o foco do escrito para o oral-escrito. O projeto partiu de uma oralidade que dinamiza a memória, inclui a expressão corporal e as habilidades linguageiras que deverão favorecer uma entrada na escrita que, ao mesmo tempo, prevê o domínio completo das dificuldades do código e a expansão de matrizes que deverão subsidiar o fluxo significativo da leitura. A experiência deu certo nas atividades coletivas, nos atendimentos individuais e mesmo com os casos mais complexos.

\section{Conclusão geral do Projeto}

A aplicação do programa nas duas salas de aula seguiu uma dinâmica interessante, embora não tenha gozado de exclusividade, já que os professores tinham que cumprir também o programa do projeto "Ler e Escrever", o que obrigava os pesquisadores a estabelecer uma convergência entre os dois programas. Quanto aos suportes, também se procurou manter trajetórias convergentes, desde o suporte corpo (memória, performance) até o suporte eletrônico, passando pelo gráfico, mas sempre abrindo possibilidades para outras linguagens. Criou-se uma ambiência de imersão e submersão de subjetividades, ou seja, facultaram-se as condições

\footnotetext{
${ }^{121} \mathrm{Na}$ escola da pesquisa o manual doado pelo Programa Nacional do Livro Didático (PNLD) fora proibido, os professores não podiam utilizá-lo em sala de aula sob a justificativa de que se tratava de uma cartilha tradicional. A obra foi analisada pela equipe, que constatou não se tratar de cartilha, mas sim de um manual com fundamentos construtivistas, embora agregando algumas poucas atividades com famílias silábicas.
} 
linguageiras básicas para movimentos subjetivos entre os diversos gêneros, meios, suportes e linguagens. A introdução do suporte eletrônico, da forma como foi feito, com atividades ricamente contextualizadas a partir da oralidade e dos livros, permitiu vislumbrar possibilidades de se introduzir o computador para os alunos das séries iniciais, mas sem as rupturas imaginárias com 0 universo da oralidade e do livro. Todos os alunos das duas séries, no início do ano, entendiam o computador apenas como uma oportunidade para "joguinhos", mas, quando se depararam com as personagens e situações vistas nos contos, nos livros e nos filmes, percebiam que estavam aprendendo a ler e, ao mesmo tempo, redescobrindo temas e personagens que já estavam em suas memórias.

Utilizando um programa que permite comandos simples ("arraste e solte", "liga pontos", "imagem-som")122, a equipe criou joguinhos de oralidade e alfabetização que permitiam divertidas brincadeiras com os textos orais vistos em sala e, ao mesmo tempo, propiciavam o uso de recursos multimídia (som, imagem, imagem em movimento, texto, hipertexto e recursividade).

Apesar de o programa planejado não ter sido aplicado com exclusividade nas duas salas, os resultados foram interessantes e promissores. O gráfico seguinte (gráfico 1 ) representa uma avaliação das seis classes de $1^{\text {a }}$ série da escola, realizada em 13 de julho de 2009, pela própria escola, a pedido da Secretaria da Educação. Notase que as duas séries acompanhadas pela pesquisa ( $B$ e $E$ )

122 O projeto trabalhou com um programa de fácil manuseio, o "Visual Class", de autoria de Celso Tatizana - que a partir dos jogos criados pelo projeto, vislumbrou amplas possibilidades de parceria, cedendo os direitos autorais de 800 licenças de uso de seu Software para nosso novo projeto. As produções do Projeto KEIZO estão expostas em seu site como uso exemplar do Visual Class no campo do ensino. Veja http://www.classinformatica.com.br/projetos/arvore 
apresentam as melhores performances, mesmo levando-se em conta apenas a classificação construtivista:

Gráfico 1

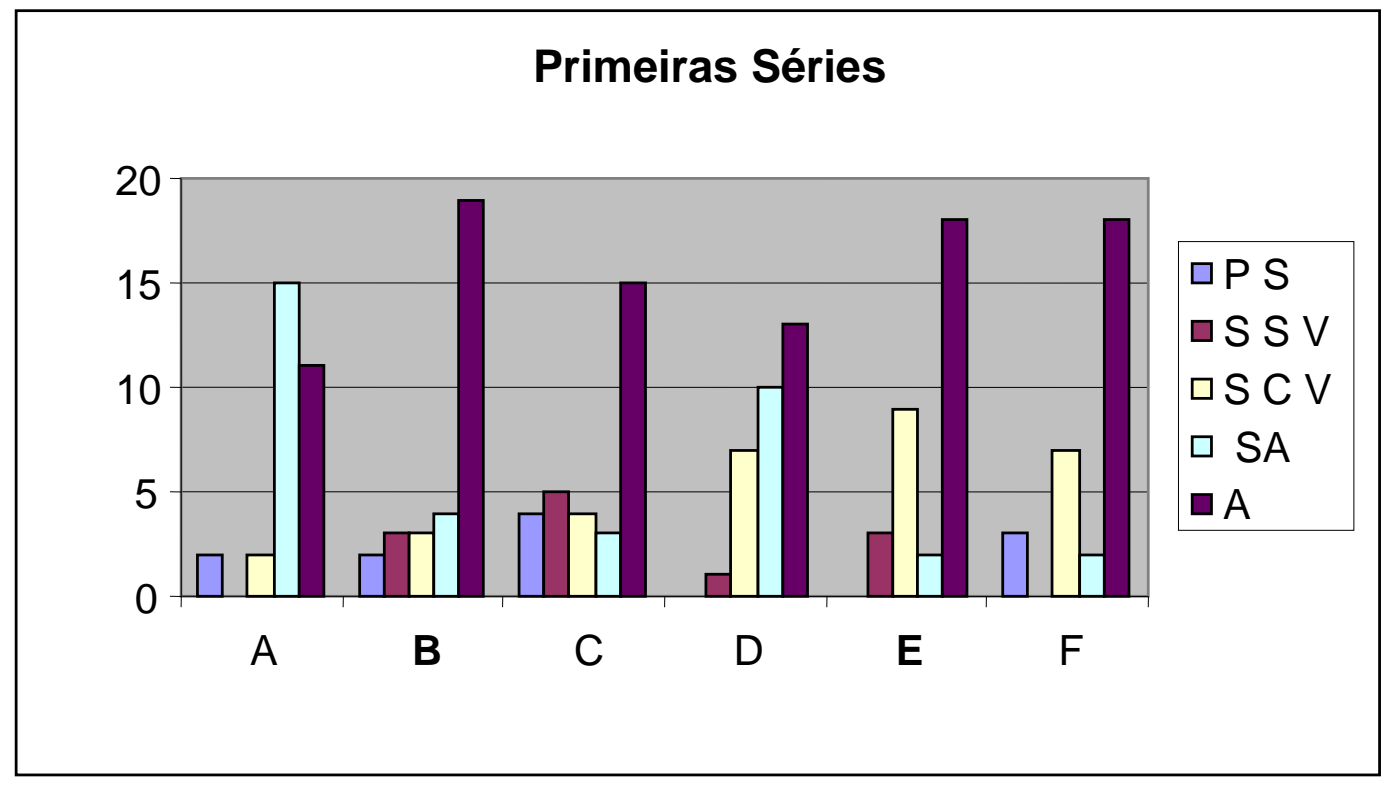

PS - Pré-silábico; SSV - Silábico Sem Valor; SCV - Silábico com Valor; SA - Silábico-Alfabético; A - Alfabético

Nos diálogos avaliativos com os alunos, realizados já nas últimas semanas de aula, em que se retomavam narrativas, jogos, brincadeiras, leituras e personagens, era possível notar com clareza duas salas dinâmicas, animadas, predispostas a continuar o trabalho - na linguagem do projeto, "duas ambiências propícias à formação de leitores". No entanto, apesar de todas as dificuldades para se avaliar habilidades de leitura, a equipe resolveu aplicar, na primeira semana de dezembro, uma avaliação final cujo objetivo era detectar mais precisamente o nível de leitura das duas salas. $O$ instrumento trazia as seguintes atividades:

- Correlação entre imagem e palavra (a imagem de uma bananeira, por exemplo, deveria ser associada à sua forma escrita correta, posta aleatoriamente entre quatro 
outras formas com segmentos quase homógrafos: barateira, banheira, pananeira, baladeira, bananeira);

- Nomeação de personagens conhecidos por meio de rébus, no computador ou no suporte gráfico;

- Leitura e compreensão de textos conhecidos escolher a alternativa correta, lendo-a com autonomia;

- Identificação de trechos de histórias (parafraseados) a partir de suas ilustrações - por exemplo, a imagem do Pequeno Polegar tirando as botas do Ogro ou do Macaco Simão comendo suas bananas deveriam ser coladas, como se fossem figurinhas, nos espaços que continham suas respectivas legendas.

O resultado geral da avaliação foi o seguinte:

Tabela 5 - Resultado geral da avaliação ${ }^{123}$

\begin{tabular}{|l|c|c|}
\hline \multicolumn{1}{|c|}{ HABILIDADES DE LEITURA } & \multicolumn{2}{|c|}{ Primeiras séries } \\
\cline { 2 - 3 } & $\mathrm{B}$ & $\mathrm{E}$ \\
\hline $\begin{array}{l}\text { Alunos que leem com fluência, sem } \\
\text { dificuldades com sílabas complexas - } \\
\text { preparados para seguir uma segunda }\end{array}$ & 22 & 21 \\
série; & & \\
\hline $\begin{array}{l}\text { Alunos que leem, mas que ainda } \\
\text { experimentam dificuldades parciais com } \\
\text { sílabas complexas, embora facilmente }\end{array}$ & 04 & 06 \\
superáveis na segunda série. & \\
\hline $\begin{array}{l}\text { Alunos que leem nomes conhecidos, que } \\
\text { identificam uma ou outra palavra usando }\end{array}$ & 02 & \\
$\begin{array}{l}\text { a primeira ou última sílaba (acrofonia), } \\
\text { que dominam o princípio alfabético, mas }\end{array}$ & & \\
ainda experimentam dificuldades na \\
identificação rápida de palavras, mesmo \\
algumas com sílabas simples. Em geral, \\
dominam a leitura de rébus. Esses alunos \\
necessitariam de um trabalho de \\
transição para a segunda série
\end{tabular}

\footnotetext{
${ }^{123}$ Note-se aqui como uma conceituação simples, baseada nas habilidades de leitura, pode ser mais efetiva e clara sobre a situação do aluno do que a de Ferreiro Y Teberosky assimilada pelos sistemas escolares de uma maneira meio genérica e descolada de sua pesquisa original.
} 


\begin{tabular}{|l|l|l|}
\hline $\begin{array}{l}\text { Alunos que ainda experimentam } \\
\text { dificuldades com o princípio alfabético, }\end{array}$ & 01 & 00 \\
que conhecem parcialmente as letras e & & \\
que ainda apresentam dificuldades na & & \\
leitura de rébus. Seria necessário refazer & & \\
a série, integral ou parcialmente. & & \\
\hline TOTAL & 29 & 30 \\
\hline
\end{tabular}

Se o monitoramento das turmas tivesse sido mais completo, com uma boa transição entre educação infantil e ensino fundamental e uma aplicação exclusiva do programa preconizado, possivelmente os resultados teriam sido ainda melhores. O que fica claro é que o foco das pesquisas e das ações pedagógicas deve se centrar mais nas singularidades pessoais e culturais da criança brasileira. A transição da oralidade para a escrita implica manejos didáticos mais contextualizados e precisos, com o monitoramento constante das defasagens de níveis desde o início do primeiro ano do ensino fundamental.

A articulação entre pesquisa acadêmica e ensino público pode avançar muito se houver um desprendimento maior de pesquisadores e educadores em relação às metodologias ou mesmo às teorias que enrijecem seus modos de lidar com a complexa realidade brasileira.

\section{CONCLUSÃO DO CAPÍTULO IV}

Se a entrada na leitura depende dessa subjetividade de entre-textos, como explicar o insucesso de certos alunos que chegam à escola com um razoável repertório oral (vimos em nosso quadro que isso pode acontecer)? A explicação pode estar nestes pontos:

- Na disjunção entre o repertório do aluno e as propostas pela escola - as concepções de letramento, da forma como entraram na escola, não evocam o que há de mais revolucionário na relação 
oralidade e escrita (que são os gêneros da infância vistos neste capítulo e no anterior);

- A modalidade performática oral que pode permitir mais mobilidade nas interações e nas possibilidades de "transferências" entre professor e aluno não é utilizada. A escrita é sempre preferida, mesmo nas sugestões presentes nos documentos oficiais (em geral, construtivistas);

- Não se fazem diagnósticos da oralidade, pressupondo-se de saída que todos os alunos vêm para a escola com um repertório homogêneo. Aliás, não se estuda o trabalho vivenciado pelo aluno na Educação Infantil (os dois segmentos não constituem uma dobradiça curricular). Mostramos em nosso projeto que eles são intercambiáveis e muito úteis para nortear escolhas de gêneros e textos que possam suprir faltas no repertório - alunos que não conseguem sequer ouvir histórias, ou mesmo memorizar um texto, podem até aprender a ler uma receita culinária curta (como a das avaliações) na pontinha do dedo, mas, em geral, não conseguirão ler textos mais longos e complexos, narrativas e textos polêmicos.

- O modelo de ciclos vigente, que preconiza um professor regendo isoladamente uma classe $(1 \times 30 / 35)$ e a promoção automática do aluno para a série seguinte, dilui as responsabilidades de tal forma que estas recaem sobre a família, reeditando a "hipótese da mãe inadequada" ou sobre a "escola pública", entendida como uma categoria abstrata já marcada pelo rótulo do fracasso. Neste ponto, as teorias e metodologias, tal como se apresentam, acabam servindo aos governos como argumentos para manter o mesmo modelo ${ }^{124}$. É preciso pensar em um modelo que articule mais os

${ }^{124}$ A Metodologia Fônica vem se destacando e se propondo como solução para a crise criada supostamente criada pelo "construtivismo" (Brasil, 2003), assim como os construtivistas cresceram discursivamente acusando a metodologia anterior. A ascensão deste ou daquele método tem que ser estudada discursivamente, como o fizemos em Belintane (2007), para que novos elementos surjam em prol de uma visão mais sistêmica e abrangente. 
professores em suas responsabilidades, por exemplo, duas duplas de professores se responsabilizando pelo período de alfabetização do aluno (primeiro e segundo anos, dois professores por sala) e uma articulação mais precisa entre Ensino Fundamental e Educação Infantil. Ou seja: tomando uma rede de ensino como a Municipal, teríamos uma articulação regionalizada por bairro, vila, entre um grupo de escolas da rede de educação infantil com as escolas do Fundamental. Uma equipe de professores se ocuparia especialmente da educação, funcionando a partir de duplas operativas cuja função é lidar com a heterogeneidade, tendo-a como constitutiva, como um fenômeno inerente à constituição das classes e turmas.

- A inexistência de um sistema de avaliação de fim de ciclo que permitisse mapear uma classe, como o que fizemos na tabela cinco. A dupla de professores de um primeiro ano pode não dar conta de todos os alunos (como aconteceu em nosso projeto), mas terá a responsabilidade de entender e de explicitar a situação de cada aluno que não logrou êxito nos objetivos esperados para a série. 


\section{CONSIDERAÇÕES FINAIS}

Se os educadores, quer nas instâncias governamentais, quer nas práticas escolares, usaram e abusaram das teorias nas últimas décadas, transpondo-as para o campo discursivo aplicado (avaliações, livros didáticos, documentos oficiais) tomando como referência certa "literalidade" dos conceitos, sem que fossem percebidos seus "litorais" (ou, como dissemos no capítulo I, sem levar em conta a essência de "peleja" de cada concepção), o que, então, podemos dizer do "canhão teórico" que montamos ao longo desses anos? Como fazer um professor compreender, por exemplo, nosso conceito de subjetividade, as relações interdisciplinares que tecem nossas propostas, ou ainda exercer a escuta tal qual mostramos no capítulo III? Que traços ficariam na escola desses nossos investimentos?

Diante dessas questões, nossa perspectiva leva em conta as críticas de Coracini (1998), que vê como simplórias e simplistas as tentativas de transpor as teorias para o campo aplicado sem levar em conta a dispersão e a heterogeneidade das situações vivenciais do ensino. O que está acontecendo com a teoria enunciativa (ou como se costuma dizer "ensino por meio de gêneros") no campo aplicado é, como vimos, sua assimilação pelo neoliberalismo, de modo a reverter-se no oposto do que preconizava o núcleo duro de sua ideologia, que é de origem marxista.

Traços dessa tendência, de tomar a parte pelo todo, já tivemos a oportunidade de observar em nossas próprias intervenções: alguns professores recém-saídos de nossos cursos curvavam a vara para o lado de uma certa oralidade e transformavam suas aulas em brincadeiras, lazer, oficina prazerosa, sem que os tópicos e estratégias assimiladas se enredassem em compromissos 
curriculares consequentes. Talvez, face à desorganização da escola ou à "autonomia" do professor brasileiro, qualquer novidade teórica seja apreendida assim, de forma isolada, na base da parte pelo todo. Essa influência direta, como já nos mostrou Coracini, de fato consistiria em uma transposição mais que ingênua, demiúrgica, que faria do outro um dócil receptáculo, ou seja, constituiria o "possível impotente".

Nossa proposta, nesse sentido, abre reflexões em dois eixos: um mais concreto, que diz respeito às políticas educacionais; outro mais difuso, que se propõe pensar a relação de um grupo de professores responsáveis por esse ciclo - com um currículo para as séries iniciais (dobradiça entre EI e EF) - que tome a oralidade em viés literário e poético como referência básica para a entrada da criança na escrita e nos meios e recursos contemporâneos.

No primeiro eixo, projetamos a possibilidade de organizar um trabalho em equipe, cuja missão se centraria na articulação entre a Educação Infantil e os ciclos iniciais do Fundamental sob a metáfora da dobradiça (capítulo III). Nesse sentido, caberia uma rediscussão do perfil desses profissionais e a assunção de uma ética que mediaria a articulação de grupos de trabalho, rompendo, assim, com o modelo do professor isolado em sua turma e monitorado meio a distância por coordenadores e supervisores. A valorização pelos governos de um perfil profissional responsável é, para nós, condição sine qua non para que de fato se encete um modelo de trabalho capaz de efetivar um verdadeiro regime de ciclos e de atribuir responsabilidades aos profissionais responsáveis por cada articulação do processo. Em contrapartida, não aceitamos a ideia de que uma metodologia ou concepção, por mais desejo de completude que tenha ("chupinhante"), possa se aventurar nas redes de ensino e efetivar mudanças a partir de um modelo que isola o professor em sua ética e responsabilidade e que também não leve em conta o "efeito peleja" de sua transposição para o campo aplicado. Conforme constatamos 
na pesquisa "Keizo Ishirara" (capítulo III), a ideia de uma equipe de profissionais (não necessariamente apenas de pedagogos, mas também de especialistas) voltada para o desafio de alfabetizar, de fato, a criança pobre da escola pública não é descabida para governos que queiram de fato fazer da leitura e do letramento uma prioridade política (como muitos países o fizeram). Diante das complexidades que levantamos, somente para este período de alfabetização, o nosso modelo, que preconiza uma dobradiça entre a Educação Infantil e os anos iniciais do Ensino Fundamental, associada ao desafio de enfrentar a heterogeneidade desde os cinco anos de idade, abriria mais objetivamente as portas para uma relação mais produtiva entre as universidades e as redes públicas de ensino. A busca das "sobras de corpo" sob a coberta, mais a tematização das diferenças e das heterogeneidades ocupariam a pauta dos pesquisadores que, dentro de um campo bem contextualizado, teriam condições de tematizar e de fato subsidiar o campo aplicado levando em conta as demandas concretas dos professores, mesmo que estas viessem questionar a eficiência da aplicação.

Quanto ao segundo eixo, sem desconsiderar a dimensão do pelejar, insistimos na importância da literatura, da função poética, da palavra polissêmica como elementos fundamentais para uma entrada na escrita que, em sua torção moëbiana, já traga os elementos mais cruciais do campo da leitura e da escrita, considerando a diversidade de suportes e os recursos midiáticos contemporâneos. Como vimos no capítulo III, a memória oral (oralidade), partindo dos textos da tradição infantil, constitui uma base de enredamento para todas os demais suportes e meios, pois é, redundantemente, a matriz da maternância. Se levarmos em conta uma subjetividade que, apesar de evanescente (e é muito bom que o seja, pois só assim pode migrar de uma linguagem para outra), se movimenta eletricamente nos intervalos, nos entre-meios tanto de textos e gêneros como de suportes e meios, podemos projetar um currículo interessante que 
recubra as duas abas da dobradiça. Fizemos isso no projeto Keizo e estamos fazendo novamente no novo projeto em rede, mas já temos evidências de que o caminho é promissor.

Para terminar, atemos as pontas da alegoria: se temos nas mãos um canhestro canhão e na frente um tico-tico esfalfado de tanto procurar os "decumê pro chupinzão", resta-nos a possibilidade de pensar que nosso canhão, como o mytho de Pessoa, só o é por não existir, ou seja, é simbólico, e como tal pode suportar operações metonímicas e metafóricas. Nessas operações, tá sempre sujeito a sofrer boas perdas (por exemplo, reduzir-se à sua mira) e, em nossas mãos, seu objetivo(a) bem provável não se fixe mais em matar o tico-tico, mas apenas observar espantado seus saracoticos e, mesmo que não queira, levará em conta que o chupinzão também aparece no foco piando em suas faltas. 


\section{REFERÊNCIAS BIBLIOGRÁFICAS}

ALCOFORADO, D.F.X. e SUÁRES ALBAN, M.del R (coord). Contos Populares Brasileiros - Bahia. Recife: Fundação Joaquim Nabuco/Editora Massangana, 2001.

ALOUCH, J. Letra a Letra: Transcrever, traduzir, transliterar. Rio de Janeiro: Campo Matêmico, 1995.

AgostinHo, Santo. "Confissões". In. Os Pensadores. São Paulo: Abril Cultural, 1984.

ANDRADE, M. Macunaíma: O herói sem nenhum caráter. São Paulo: Livraria Martins, 1977.

ANDRÉ, M. e LÜDKE, M. Pesquisa em educação: abordagens qualitativas. São Paulo: EPU, 1986.

BAJARD, E. "Afinal, onde está a leitura?". Cadernos de Pesquisa. São Paulo: Fundação Carlos Chagas, no. 83, 1992 (pp. 29-41).

BAKHTIN, M. M. A cultura popular na Idade Média e no Renascimento: contexto de François Rabelais São Paulo: Hucitec; Brasília: Editora da UNB, 1999.

Hucitec, 1995. e VOLOCHINOV, V.N. Marxismo e filosofia da linguagem. São Paulo:

BANDEIRA, M. "Itinerário de Pasárgada", in. Poesia Completa e Prosa. Rio de Janeiro: Nova Aguilar, 1996 [27-102]

BARROS, M. O livro das ignorãças. Rio de Janeiro: Record/Altaya, 1993.

BARTHES, R. O prazer do texto. Trad. Maria Margarida Barahoma. Lisboa: Edição 70.

Brasileiense, 1988. [pp40-42].

BATISTA, A. A. G. "A avaliação dos livros didáticos: para entender o programa nacional do livro didático (PNLD). In. Livro didático de Língua Portuguesa, letramento e cultura da escrita. Organizadores: Rojo, R. Batista, A.A.G. Campinas, SP: Mercado de Letras, 2003

BELINTANE, C. "Matrizes e Matizes do oral". Revista Doxa - Revista Paulista de Psicologia e Educação, Vol. 9.: Araraquara: SP, 2005 (pp.23-45)

"Leitura e Alfabetização no Brasil: uma busca para além da polarização. In. Educação e Pesquisa. V. 32, no. 2. São Paulo: Feusp, 2006a (pp. 261-277)

"Subjetividades Renitentes". In Linguagem e Educação: Implicações técnicas, éticas e estéticas. Rezende, N. Riolfi, C. Semeghini-Siqueira, I. São Paulo: Humanitas/FFLCH/USP, 2006b. pp. 73-105.

"As novas tecnologias: o cyberaluno In: Memórias da Pedagogia: Perspectivas para o novo milênio. Ed.Rio de Janeiro : Relume-Dumar : Ediouro; São Paulo: Segmento-Dueto, 2006c v.06, pp. 85-97. 
"Abordagem da oralidade e da escrita na escola a partir da tessitura interdisciplinar entre a psicanálise e a linguística". An 6 Col. LEPSI IP/FE-USP. http://www.proceedings.scielo.br/scielo., 2006c.

2007, pp. $135-158$

"Adivinha, leitura e desejo". In. Calil, E. São Paulo: Editora Cortez,

"Vozes da Escrita: entre crianças e menestréis". In Estilos da Clínica/Instituto de Psicologia. Vol. 1. No. 1 - São Paulo, USP-IP, 2008, pp. 36-51

. "Alunos rebeldes". In. Doenças do Cérebro: Hiperatividade e epilepsia. Vol. 3. Mente Cérebro. São Paulo: Duetto, 2009.

A alienação e a separação na paródia: uma estratégia para a produção de texto com alunos das séries finais do ensino fundamental. Coletânea organizada por Oliveira, E. C. \& Borè (org), C. in. L'école, l'écriture et la création. Brasil/França, 2009 (prelo)

. "Oralidade, alfabetização e leitura: enfrentando diferenças complexidades na escola pública" In. Educação e Pesquisa. Vol.36 n. 3. São Paulo: Feusp, 2010, pp. 685-703

BENJAMIN, Walter. Obras escolhidas. São Paulo: Editora Brasiliense, 1986.

BERNSTEIN, B. "Estrutura Social, linguagem e aprendizagem". In. Patto, M. H. S, Introdução à Psicologia Escolar. São Paulo: Casa do Psicólogo, 1997 pp. 145-169.

BORGES, S. O quebra-cabeça da escrita: a alfabetização depois de Lacan. Goiânia: Ed. Da UCG, 2006.

BOSCO, Z. R. No jogo dos significantes: a infância da letra. Campinas: Pontes, 2002.

Pontes, 2009

A errância da letra: o nome próprio da criança. Campinas, SP:

BRASIL (SAEB). Resultados do SAEB/2003. Junho de 2004 (versão preliminar). Brasília: INEP.

Disponível em: http://www.inep.gov.br/basica/saeb/default.asp>

BRASIL, Parâmetros Curriculares Nacionais/Ensino Fundamental ( $1^{a} \quad a^{a} 4^{a}$ ). Ministério da Educação e do Desporto. SEF. Brasília: MEC/SEF, 1998a.

Parâmetros Curriculares Nacionais/Ensino Fundamental ( $5^{a}$ a $8^{a}$ ). Ministério da Educação e do Desporto. SEF. Brasília: MEC/SEF, 1998b

BRASIL. Relatório Final do Grupo de Trabalho Alfabetização Infantil: os novos caminhos. Seminário "O Poder Legislativo e a Alfabetização Infantil: Novos Caminhos" em 15 de setembro de 2003. Comissão de Cultura e Educação da Câmara dos Deputados, 2003. Disponível em <http://www.mec.gov.br>

BRASIL, Ministério da Educação: PDE: Plano de Desenvolvimento da Educação: Prova Brasil: Ensino Fundamental: matrizes de referência, tópicos e descritores. Brasília: MEC, SEB, INEP, 2008/2009.

BRASIL, Relatório Final do Grupo de Trabalho Alfabetização Infantil: os novos caminhos. Seminário "O Poder Legislativo e a Alfabetização Infantil: Novos 
Caminhos" em 15 de setembro de 2003. Comissão de Cultura e Educação da Câmara dos Deputados, 2003. Disponível em <http://www.mec.gov.br>.

BRASIL, Parâmetros nacionais de qualidade para a educação infantil. Vol. 1. Brasília: MEC, SEB, 2006. http://www.mec.gov.b

BRONCKART, J.P. Atividades de linguagem, textos e discursos. São Paulo: EDUC, 1999.

CASCUDO, L. C. Contos tradicionais do Brasil. Rio de Janeiro: Ediouro, 1998 Dicionário do Folclore Brasileiro. Rio de Janeiro: Ediouro, 1998b

CAVALO, G. e CHARTIER, R.(org) "Introdução". In. História da Leitura no Mundo Ocidental. São Paulo: Editora Ática, 1998 (pp.5-40)

CERTEAU, M e Outros. A Invenção do Cotidiano, vol.2 Petrópolis: Vozes, 1996.

Charaudeau, P. e MAIngueneAu, D. Dicionário de Análise do Discurso. São Paulo: Contexto, 2004.

CHARTIER, R (org.) História da Leitura no mundo ocidental. São Paulo: Editora Ática, 1998 (pp. 147-184).

- A aventura do livro: do leitor ao navegador. São Paulo: Editora UNESP/Imprensa Oficial do Estado, 1999.

2001.

. Cultura Escrita, Literatura e História. Porto Alegre: ARTMED Editora,

CORACINI, Maria José R. F.. "A teoria e a prática: a questão da diferença no discurso sobre e da sala de aula". DELTA [online]. 1998, vol.14, n.1,pp. 33-57. Disponível em: http://www.scielo.br/scielo. [citado 2011-08-22]

CORREIA, M.L.G. O modo heterogêneo de constituição da escrita. São Paulo: Martins Fontes, 2004.

DE LEMOS, C.T.G. Los processos metafóricos y metonímicos como mecanismos de cambio. Substratum, v. 1, n. 1, 1992.

. "Sobre a aquisição da escrita: algumas questões". In. Alfabetização e Letramento. Rojo. R.(org.). São Paulo: Mercado de letras, 1998 (pp. 13-53).

"Das vicissitudes da fala da criança e sua investigação". In. Caderno de Estudos Linguísticos (no. 44). Campinas:SP: 2002 pp. 41-69.

DERRIDA, J. Gramatologia. São Paulo: Perspectiva, 1973.

A escritura e a diferença. São Paulo: Perspectiva, 1995.

DRUMMOND, C. de A. Obra Completa. Rio de Janeiro, José Aguilar Editora, 1992

DUFOUR, Dany-Robertt. Os mistérios da trindade. Rio de Janeiro: Companhia de Freud Editora, 2000.

A arte de reduzir cabeças: sobre a nova servidão na sociedade liberal. Rio de Janeiro: Companhia de Freud, 2005 
ESCHER, M. C. Gravuras e Desenhos. Köln: Taschen, 1994.

FERREIRA, Emília y TEBEROSKY, Ana. Los Sistemas de Escritura en el Desarrollo del Niño. México: Editora Siglo Ventiuno Editores, 1989 (11a. Edição).

FÉVRIER, J. Histoire de L'Écriture. Paris: Payot, 1948.

FOUCAMBERT, A leitura em questão. Porto Alegre: Artes Médicas, 1994.

FOUCALT, M. A ordem do discurso: aula inaugural no Collège de France, pronunciada em 2 de dezembro de 1970. São Paulo: Edições Loyola, 1996

FREIRE, P. A importância do ato de ler: em três artigos que se complementam. São Paulo: Cortez, 1982.

FREUD, S. A interpretação das Afasias: um estudo crítico. Lisboa: Edições 70, 1977

FREUD, S. Edição Standard das Obras Completas de Sigmundo Freud. Tradução e direção Geral: Jaime Salomão - 2a, Edição. Rio de Janeiro: Imago, 1988. Volumes consultados:

Vol. I: "Projeto Para Uma Psicologia Científica" (1895), pp. 347-469

Vol. IV e V: A Interpretação de Sonhos. (1900)

Vol. V. Psicopatologia da Vida Cotidiana. (1901)

Vol. VIII : O Chiste e sua relação com o inconsciente. (1905)

220.

Vol. XII : "O Sonho no Folclore".(1911) (Oppenheim e Freud), pp.193-

"Notas Psicanalíticas sobre um relato autobiográfico de um caso de paranoia (dementia paranoides)" (1911), pp.15-87

(1912) pp. 125-133.

"Recomendações aos médicos que exercem a psicanálise"

Vol. XIV : "O Inconsciente"(1915), pp. 191-239

pp.305-308

Vol. XIX : "Prefácio a juventude desorientada, de Aichhorn (1925),

Vol. XXIII "Moisés e o Monoteísmo" (1939), pp. 19-150

Vol. XXIII. Análise Terminável e Interminável (1937), pp. 247-290

FREUD, S. Obras Psicológicas de Sigmund Freud. Tradução: Luiz Alberto Hanz. Volumes:

Vol. 1: O Recalque (1915), 2004 , pp. 175-186

Vol. 2: "O Inconsciente" (1915), 2006, pp.13-74

Vol. 2: "Além do Princípio do Prazer" (1920), 2006, pp.123-198

Vol. 3: "O Eu e o Id" (1923), 2007, pp. 13-92

FREYRE, Gilberto. Casa Grande \& Senzala, Rio de Janeiro: Editora Record, 2001.

GARCIA-ROSA, L. A. Introdução à metapsicologia freudiana. Volume 1. São Paulo: Editora Jorge Zahar, 2004.

GELB, J. I. Historia de la escritura. Madrid-Espanha: Alianza Editorial, 1952/1976

GERALDI, J. W. Portos de Passagem. São Paulo: Martins Fontes, 1997

. Linguagem e ensino: exercícios de militância e divulgação. Campinas: ALB

e Mercado de Letras, 1997.

GINZBURG. C. Estranhamento: pré-história de um procedimento literário. In. Olhos de madeira. São Paulo: Companhia das letras, 2001. [pp. 15-41] 
. "Sinais: Raízes de um Paradigma Indiciário". In. Mitos, Emblemas e Sinais: Morfologia e História. São Paulo: Companhia das Letras, 1989. [143-179]

GIORJON, M. C. P. o Contexto tem texto. Campos relacionais de pais e escola. Dissertação de Mestrado. São Paulo: FEUSP, 2010.

GNERRE, Maurizio. Linguagem, Escrita e Poder. São Paulo: Martins Fontes, 1998.

GOODY, J. A lógica da escrita e a organização da sociedade. Lisboa: Edições 70, 1986.

GOODY, J. \& WATT, I. As consequências do letramento. São Paulo: Paulistana, 2006.

GOODMAN, K. Introdução à linguagem integral. Porto Alegre: Artes Médica, 1997.

GRANON-LAFONT, J. A topologia de Jacques Lacan. Paris: Jorge Zahar Editor, 1988.

GREGOIRE, A. L'apprentissage du langage. Paris: Librairie Fêlix Algan, 1993

HAVELOCK, E. "A Equação Oralidade-Cultura Escrita : Uma Fórmula para a Mente Moderna" In OLSON, David R. e TORRANCY, Nancy. Cultura Escrita e Oralidade. São Paulo: Editora Ática, 1991/1995.

. Prefácio a Platão. Campinas, SP. Papirus, 1996a

. A revolução da Escrita na Grécia. São Paulo: Editora da Universidade Estadual Paulista; Rio de Janeiro: Paz e Terra, 1996b.

A musa aprende a escrever: reflexões sobre a oralidade e a literacia da Antiguidade ao presente. Lisboa: Gradiva, 1996c

HOUSTON, S.H. "Um reexame de algumas afirmações sobre a linguagem da criança de baixo nível socioeconômico". In. Patto, M. H. S, Introdução à Psicologia Escolar. São Paulo: Casa do Psicólogo, 1997 (pp. 171-191).

ISER, W. O ato da leitura. vol. 1. São Paulo: Ed. 34, 1996.

JAKOBSON, R. "Dois aspectos da linguagem e dois tipos de afasia. In Linguística e Comunicação. São Paulo: Cultrix, 1995 [pp.34-62]

Cultrix, 1995b [pp. 118-162]

"Linguística e Poética". In Linguística e Comunicação. São Paulo:

KLEIMAN, A. Os significados do letramento. Campinas: Mercado de Letras, 1995.

KRAMER, S, Alfabetização, leitura e escrita: formação de professores em curso. São Paulo: Ática, 2001

KUHN, Thomas S. A estrutura das revoluções científicas. São Paulo: Perspectiva, 1997.

LACAN, J. Seminários... Livros.... Rio de Janeiro. Editora Zahar

2: O Eu na teoria de Freud e na técnica psicanalítica, (1954-1955), 1985 
3.: As psicoses (1955-1956), 1992,

5. As Formações do inconsciente. ((1957-1958), 1999.

11: Os quatro conceitos fundamentais da psicanálise.(1964)( 1993

16. "De um Outro ao outro".(1968-1969), 2008

20. Mais, ainda.(1972-1973); 1985.

23. O sinthoma (1975-1976), 2007.

Lacan, J. Escritos. Rio de Janeiro, Jorge Zahar, 1998:

" "O Seminário sobre a carta roubada" (pp.13-66), (1956)

"A instância da letra no inconsciente ou a razão desde Freud". [p.

496-533], (1957)

"Subversão do sujeito e dialética do desejo no inconsciente" Freudiano. (pp. 807-842), (1960)

. Conférence donnée au Centre culturel français le 30 mars 1974. Apud

Holthausen, M. in. http://psicanaliselacaniana.blogspot.com/2009/02/lalingua-oualingua-pequeno-percurso.html (consulta em julho de 2011)

. Livro 9: A identificação (1961-1962). Recife: Centro de Estudos Freudianos do Recife, 2003. (versão de estudos)

português)

(1974-1975/s.d.) R.S.I. O seminário. (Versão anônima, em francês e

LAHIRE, B. Sucesso escolar nos meios populares: as razões do improvável. São Paulo: Editora Ática, 1997.

LEICK, G. Mesopotâmia: a invenção da cidade. Rio de Janeiro: Imago, 2003.

LIMA, S. O. Leitura e oralidade: as inscrições do desejo no percurso de formação do leitor. Tese de Doutorado São Paulo, SP: Feusp, 2006.

LIMA, J. Antologia poética. Rio de Janeiro: José Olympio, 1978

LISBOA, H. Literatura oral para a infância e a juventude.: lendas, contos e\& fábulas populares no Brasil. São Paulo: Peirópolis, 2002.

LORD, Albert B. The Singer of Tales. Londres: Harvard University Press, 1997.

LUCAS, G. L. C. Oralidade, Psicanálise e ensino de língua materna: experiência com crianças oriundas de ambientes desfavorecidos. Dissertação de Mestrado. São Paulo: FEUSP, 2010

LUDKE, M. e ANDRÉ, M. E. D. Pesquisa em Educação: Abordagens qualitativas. São Paulo: EPU, 1986.

LURIA, A. R. A mente e a memória: um pequeno livro sobre uma vasta memória. São Paulo: Martins Fontes, 1999

MACLUHAN, Marshal. Os meios de comunicação como extensões do homem (understanding media). São Paulo: Cultrix, 2006.

MANGUEL, Alberto. Uma história da leitura. São Paulo: Companhia das Letras, 1997.

MARCUSCHI, L. A. "Oralidade e ensino de língua: uma questão pouco falada". Trabalhos em Lingüística Aplicada, n. 30, 1997, p.39-79. 
Cortez, 2001.

Da fala para a escrita: atividades de retextualização. São Paulo:

"Leitura como processo inferencial num universo cultural-cognitivo". In. Barzotto, V. Estado de Leitura. Campinas: São Paulo, 1999.

MELO, M. J. M. de. Enigmas Populares. Rio de Janeiro: Editora A Noite, MELO, V. Folclore Infantil. Itatiaia, 1985

MILNER, J. C. O Amor da Língua. Porto Alegre: Artes Médicas, 1987.

MORAIS, J. A arte de ler. São Paulo: Editora da Universidade Estadual Paulista, 1996.

MOTA, L. Cantadores. Belo Horizonte: Editora Itatiaia, 1987.

MURILO MENDES, Mundo Enigma. Rio de Janeiro: Editora Globo, 1945

NASIO, J. Cinco Lições sobre a Teoria de Jacques Lacan. Trad. Vera Ribeiro. - Rio de Janeiro: Jorge Zahar Ed., 1993.

NOBREGA, Antônio. "Estória da Coca". Obra de folclore recolhida por D. Esther Pedreira de Cerqueira). Compact Disc, Manaus: Eldorado (contracapa da versão regravação s/d), 1983.

OCDE-PISA-2000. Programa Internacional de Avaliação de Estudantes - PISA. Disponível em <http:www.inep.gov.br> Acesso em: 05 de março de 2003).

OLIVEIRA, E. C. Autoria: a criança e a escrita de histórias inventadas. Londrina: Eduel, 2009.

OLSON, David R. O mundo no papel. São Paulo: Editora Ática, 1997.

ONG, Walter J. Oralidade e cultura escrita: a tecnologização da palavra. (tradução Enid Abreu Dobranszky) Campinas.Sp: Papirus, 1998.

ORTEGA y GASSET, J "El Quijote en la escuela". Revista da Faculdade de Educação. Volume 19, no. 1. São Paulo: Feusp, 1993.

PAES, J. P. Poemas para brincar. São Paulo: Editora Ática, 2006.

PASTORELLO, L. Leitura em voz alta, produção da subjetividade e entrada da criança na escrita. Tese de Doutorado. São Paulo: FEUSP, 2009

PATTO, M. H. S (org.), Introdução à Psicologia Escolar. São Paulo: Casa do Psicólogo, 1997.

PERRONI, M.C. Desenvolvimento do Discurso Narrativo. São Paulo: Martins Fontes, 1992.

PÊCHEUX, Michel. Semântica e Discurso. Campinas: Editora da Unicamp, 1988. "O discurso: estrutura ou acontecimento". Campinas, SP: Pontes, 1997. 
PIRES, C. Conversas ao pé do fogo - da Coleção "conversa caipira". Itu-SP, Editora Ottoni, 2001.

PLATÃO. A República. Bauru-SP, Edipro, 2001. Fedro. São Paulo: Martim Claret, 2003. ."O banquete". In. Coleção: Os pensadores (vol III). São Paulo: Abril Cultural, 1972 (pp. 12-59).

POMMIER, G. Naissance et Renaissance de L'Écriture. Paris: Press Universitaire de France, 1993.

PROL OTERO, L. A. O que (não) está escrito? Oralidade poética e leitura nos processos de alfabetização e letramento. Dissertação de Mestrado. São Paulo : FEUSP, 2010

RAMOS, G. São Bernardo. Rio de Janeiro: Record, 1996. Infância. São Paulo: Martins, 1972.

RANCIÈRE, J. O inconsciente estético. São Paulo: Ed. 34, 2009.

REGO, C. M. Traço, Letra, escrita: Freud, Derrida, Lacan: Rio de Janeiro: 7 Letras, 2006

ROJO, R.(Org). Alfabetização e letramento: perspectivas lingüísticas. Campinas: Mercado de Letras, 1988.

ROMERO, S. Contos Populares do Brasil. São Paulo: Landy, 2008

SAENGER, P. "A leitura nos séculos finais da idade média". In. Cavalo, G. História da Leitura no Mundo Ocidental. São Paulo: Editora Ática, 1998 (pp.5-40)

SAFOUAN, M. O inconsciente e seu escriba. Campinas, SP: Papirus, 1987.

SÃo PAULO (SP). Projeto "Toda Força ao 10. Ano": Guia para planejamento ao professor alfabetizador - orientações para o planejamento e avaliação do trabalho com o 10. Ano do Ensino Fundamental / Secretaria Municipal da Educação - São Paulo: SME / DOT, 2006.

SÃO PAULO (Estado), Secretaria da Educação. Ler e Escrever: guia de planejamento e orientações didáticas; professor alfabetizador $1^{a}$. série. São Paulo: FDE, 2008

SARTORE, A. R. Escrita e Angústia: ponderações por um viés psicanalítico. 2005. Tese de Doutorado. São Paulo: FE-USP, 2005

SAUSSURE, F. de. Curso de Linguística Geral. São Paulo: Editora Cultrix, 1916.

SCHREBER, D. P. Memórias de um doente dos nervos. São Paulo: Editora Paz e Terra, 1995

SINGH, S. O livro dos códigos: a ciência do sigilo: do antigo Egito à criptografia quântica. Rio de Janeiro: São Paulo: Editora Record, 2001

SMITH, F. Leitura significativa. Porto Alegre: Artes Médicas, 1989. 
SMOLKA, A. L. B. A criança na fase inicial da escrita: a alfabetização como processo discursivo. São Paulo: Cortez; Campinas-SP: Editora da Universidade Estadual de Campinas, 2003.

SOARES, M. Linguagem e escola: uma perspectiva social. São Paulo: Editora Ática, 1989.

TFOUNI, L. V. "A escrita: remédio ou veneno?" In: AZEVEDO, M. A.; MARQUES, M. L. Alfabetização hoje. São Paulo: Cortez, 1997.

"Autoria e contenção da Deriva". In. Tfouni, L. V. (org). Múltiplas Faces da Autoria. Ijuí: Editora Unijuí, 2008.

"A dispersão e a deriva na constituição da autoria e suas implicações para uma teoria do letramento". in. Signorini, I e outros (orgs.). As teorias do letramento: investigando a leitura e a escrita. Campinas: SP: Mercado de Letras, 2008, (p.77-94)

VIGOTSKI, L. S. Pensamento e Linguagem. São Paulo: Martins Fontes, 1987.

ZILBERMAN, R (org.) Leitura em crise na escolas: as alternativas do professor. Porto Alegre: Mercado Aberto, 1988.

WEITZEL, A. H. Folcore Literário e Linguístico. Juíz de Fora: Editora da UFJF, 1995.

\section{MANUAIS DIDÁTICOS.}

Infância Feliz: letramento, alfabetização e linguística (primeiro ano). São Paulo: Escala Educacional (PNLD 2010, 2011, 2012). Org. Albanize Arêdes, Ângelo Alexandre, Mirian Grillo.

Pensar e viver: Letramento e alfabetização linguística (primeiro ano). São Paulo: Editora Ática (PNLD 2010, 2011, 2012). Org. Cláudia Miranda, Eliete Presta.

L.E.R.: Leitura, escrita e reflexão (primeiro ano). São Paulo: FTD (PNLD 2010, 2011, 2012). Org. Marcia das Dores Leite, Beatriz de Carvalho Morelli, Luciana Corrêa Guimarães.

L.E.R. Leitura, escrita e reflexão: letramento e alfabetização linguística. São Paulo: Editora FTD (PNL 2010, 2011, 2012). Org. Márcia Leite, Beatriz Morelli, Luciana Guimarães. 